


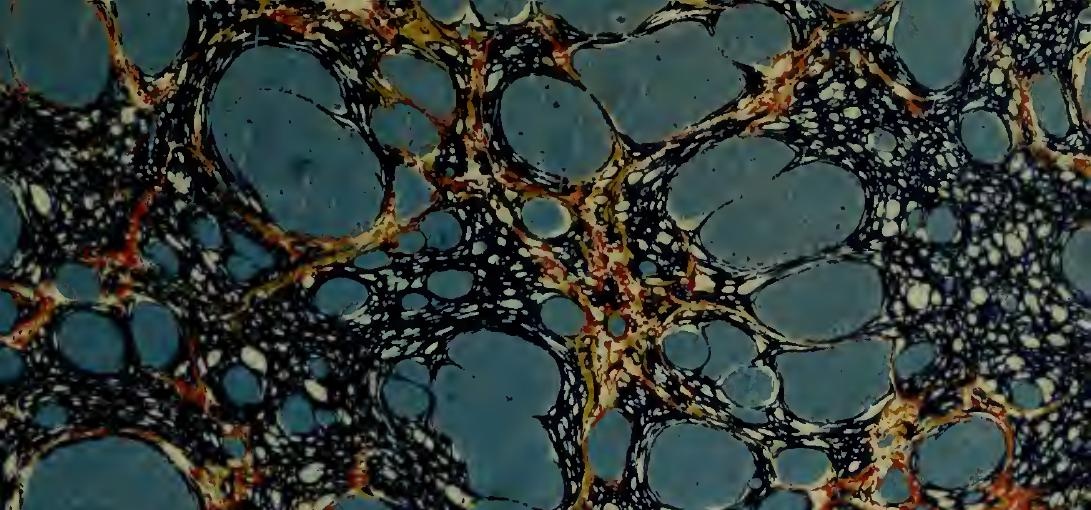

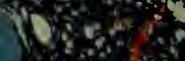
ant $\Rightarrow$

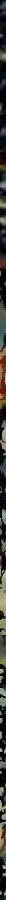

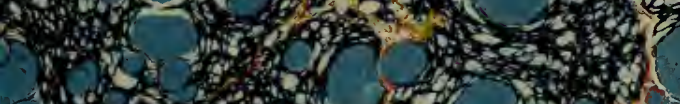

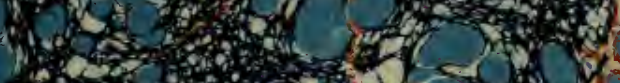

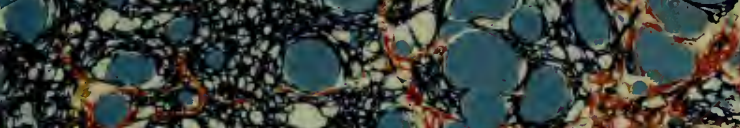
(4)

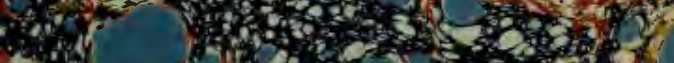







$$
\text { I }
$$




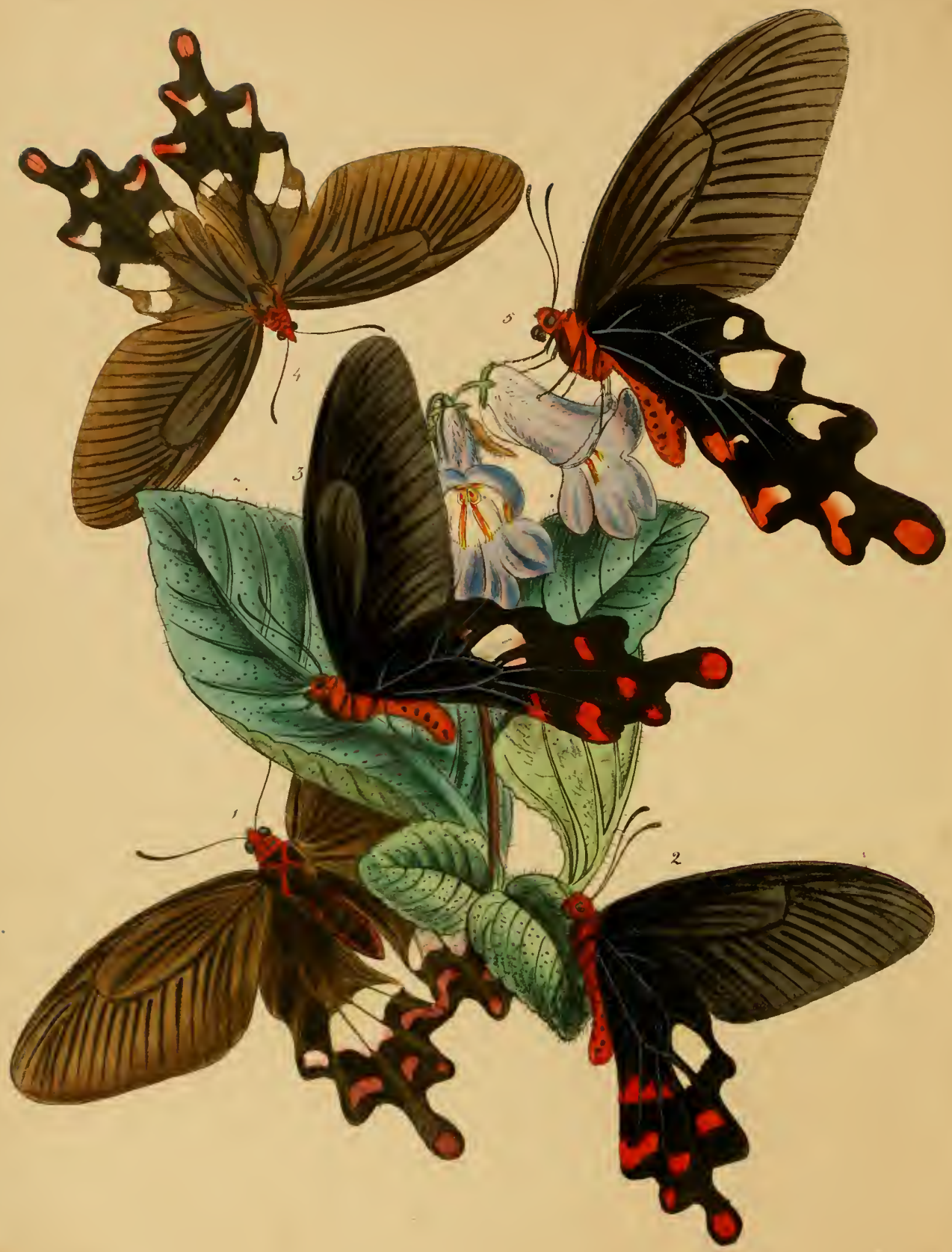





\section{THE C A B I N E T}

\section{ORIENTAL ENTOMOLOGY;}

BEING

\section{A Eclection of}

SOME OF TIIE RARER AND MORE BEAUTIFUI, SPECIES OF INSECTS,

NATIVES OF INDIA AND THE ADJACENT ISLANDS,

THE GREATER PORTIOX OF WHICI ARE NOW FOR THE FIRST TIME DESCRBED AND FIGURED.

$B \mathrm{I}$

J. O. WESTWOOD, ESQ., F.L.S.,

HON, MEN. HIST, SOC, QUEBEC ; SOC. NAT, HIST., BOSTON, $r$.S.; ENT. SOC. PENNSYLVANIA, AND ENT. SOC, STETTIN ; MEN, SOC. CAES. NAT, CLR, MOSCOW ; PHYSTOGR. SOC., LUND; SOC. ROY. SCI, LILLE; SOC. KOY., LYONS ; SOC, HIST. NAT., MAURTTIIS; SOC. CUVIERR, ET PHILOMAT, PARIS ; LTT. FHIL. AND NAT. HIST, SOCS., BELFAST, TORQUAY, RICHMOND, BHEFFIELD; MEM, SOC, ENTOMOL. DE FRANCE, SECR, EXT, SOC., LONDON, ETC,

LON DON:

WILLIAM SMITH, 113, FLEET STREET. MDCCCXLVII. 



\section{SYSTEMATIC ARRANGEMENT}

OF THE

\section{INSECTS DESCRIBED AND FIGURED IN TIIE PRESENT WORK.}

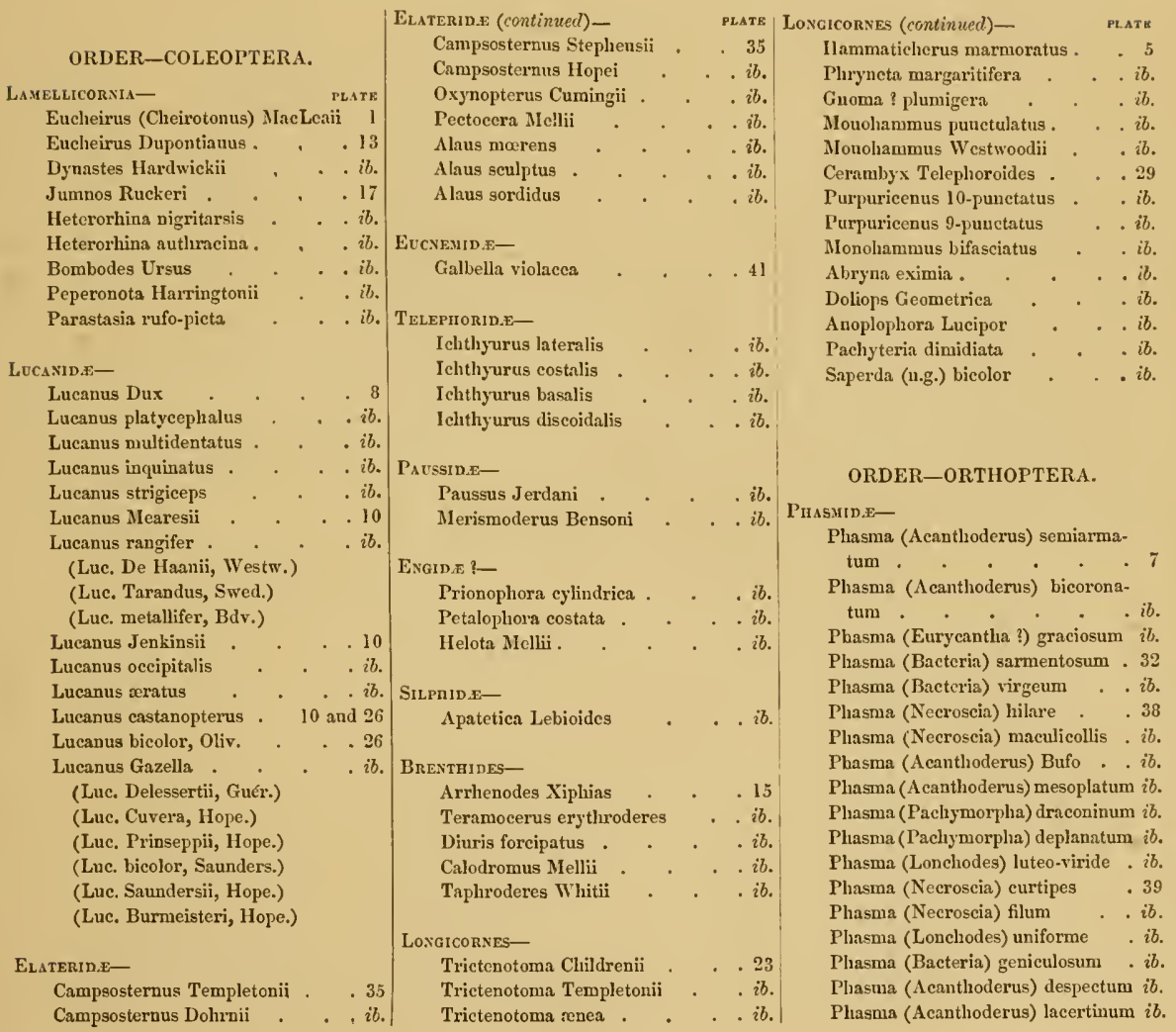


GrYLLin.e-

Phaneroptera perlaria , . 16

Megalodou eusifer . . . . $i b$.

Pseudopliyllus 4-tuberculatus . . ib.

Aeanthodis imperialis . . . 25

Acanthodis Donovani . . . it.

Plylloptera sanguinolenta . . it.

Pliylloptera 8-maculata . . . ib.

\section{ORUER-NEUROPTERA.}

Plaxipexnes-

Ascalaphus tessellatus . . . 34

Ascalaphus segmentatur' . . . it.

Asealaphus canifrons . . . it.

Asealaphus dentifer . Page 69

Ascalaphus angulatus . . . ib.

Ascalaphus obscurus . . . . i

Myrmeleon singulare . Plate 34

Chauliodes subfasciatus . . . it.

Nemoptera filipennis . . . il.

Mantispa nodosa . . . . ib.

\section{ORDER-LEPIDOPTERA.}

Diurna-

Papilio (Ornithopterus) Poseidon,

male . . . . . 11

Papilio (Ornithopterus) Poseidon,

fenale . . . . 14 Agaristine-

Papilio Icarius . . . 2

Papilio Minereus . . . . 40

Papilio Philoxenus . . . 2 2 .

Papilio Evan . . . . . 31

Papilio Elephenor. . . . . it.

Papilio paradoxus . . . 9

Papilio Caunus . . . . ib.

Papilio Astiua . . . . . . il.

Morpho (Thaumantis) Camadeva . 4

Amathusia Amythaon $\quad . \quad .19$
Dil rasa (continued).

Amathusia Patalena

Amathusia Plilarchus

Nymphatis Euphrone

Claraxes Dolon

Charaxes Psaphon

Euploea Deione

Acontia Doubledaii . . . . il.

Hestia Hypermnestra . . . . $i b$.

Hestia Belia . . . . ib.

Hestia Lasonia . . . 42

Crepuscllaria-

Sphinx (Acherontia) Lethe . . 42

Splinx (Acherontia) Styx . . $i b$.

Sphinx Orneus . . . . . 6

Sphinx (Chorocampa) Dolichus . 30

Sphinx (Ambulyx) substrigilis . . il.

Deilephila Cyrene . . . . 6

Smeriuthus? Panope . . . it.

Macroglossa Triopus . . . . ib.

Sesia infernalis . . . . 30

Troehilium Ashtaroth . . . 6

Troehilium Astarte . . . . 30

Trochilium Eurytion . . . il.

Trochilium Ceto . . . . ib.

Troehilium Phorcus . . . il.

Eusemia maculatrix . . . 33

Eusemia bellatrix . . . . ib.

Eusenia victrix . . . . ib.

Eusemiz amatrix . . . . ib.

Eusemia dentatrix . . . i i .

BoMnYCIDE-

Saturia Simla . . . 20

Saturnia Assama . . . . il.

Saturnia Larissa $\quad$. . . 24
Bojatcide (continued). Plate Saturnia Pyretorum . . . 24

Saturnia Zuleika . . . 12

Saturnia Katinlia . . . . ib.

Saturnia Lola . . . . ib.

Saturnia (Actias) Mieuas . . 22

Bombyx Jluttoni . . . . 12

Limacodes hilaris . . . . 24

Limacodes graciosa . . . . it.

Limacodes lacta . . Page 50

Leucophlebia lineata . Plate 22

Nocturne-

Phyllodes ustulata $\quad$. 28

Phyllodes consobrina . . . it.

Erebus rivularis . . . . ib.

Noctua (Apatela ?) radians . . i6.

\section{ORDER-HOMOPTERA.}

Fulgoride-

Fulgora clavata . . . 3

Fulgora gemmata . . . . ib.

Fulgora guttulata. . . . i $i$.

Fulgora vireseens . . . . $i b$.

Fulgora viridirostris . . . $i b$.

Fulgora Spinolæ . . . . 36

Fulgora oculata . . . . $i b$.

Aphæena seutellaris . . . . $i b$.

Aphœna imperialis . . . $i b$.

Ancyra appendiculata . . $i b$.

\section{ORDER-DIPTERA.}

Diopsis Westwoodii . . . 18

Diopsis subnotata . . . $i b$. Sphryracephala Hearseiana . . ib. Achias maculipennis . . . . ib. Colax? variegatus . . . it.

\section{E R R A T A.}

Page 3, line 29, dele "movable."

Pages 15, 16, make the specific names and characters neuter, to agree with "Phasma."

Page 21, line 44, for "serratus," read "serratis."

„28, Dynastcs Hardwickii and its variety D. Childrenii Hope, together with D. Cantori Hope, Trans. Eut. Soc. IV. T6, have heen formed lyy Dr. Burmeister into a separate genus Eupatorus, llandb. d. Ent. V., p. 268.

23 36, Dr. Schaum considers Heterorhina authracina as a variety of $\mathrm{H}$. elegans.

" 43, Charaxes Psaphou is stated by Dr. Templeton to be a variety (male?) of Charaxes Bernardus.

" 48, Trictenotoma Templetonii. Captain Parry has obtained the female of this species from Ceylon; it very much resembles that of T. Childrenii, but has transversely rugose mandibles, the last dorsal segment of the abdomen sliort, \&e.

" 56, Nymphalis Euphrone is identical with Diadema Lisarda. Doubleday, Ann. Nat. Hist. xvi. p. 253.

Pages 65 and 66, add "Phasma" as a generic name, making "Bacteria" subgeneric and the specific names neuter. 


\section{N O T I C E.}

'THE object of the Work now offered to the notice of the Entomologist and lover of Nature in general, is to present a Series of Figures of some of the rarer and more splendid species of Insects which have within these few last years been forwarded to England, from the various districts of India and the adjacent islands.

It is indeed surprising that, notwithstanding the rast extent of our Indian territories, and the extraordinary brilliancy of many of the Entomological productions of that portion of the globe, we should hitherto have had no work expressly deroted to the Insects of India, except the single volume published by Mr. Donovan, nearly fifty years ago; whilst, nevertleless, our cabinets, owing to the zeal with which this branch of Zoology is pursued by many Entomologists in those regions, tecm with novelties which would aloue form the materials of many rolumes.

A most elaborate work, indeed, on the Lepidopterous Insects of Jara, was commenced by Dr. Horsfield, nearly twenty years ago, which, lad it been completed, would have left nothing to be desired on that branch of the subject, so far as the Javanese species are concerned. Auother work, also of a very splendid character, has been commenced by Dr. De Haan, on the Insects of the Dutch Settlements in the East, of which, however, two numbers only have yet appeared, restricted to two groups of Insects. A partial attempt to remedy this consequent deficiency was made in my "Arcana Entomologica," in which several interesting Oriental groups were illustrated; but the small size of the plates of that work prerented the introduction of many of the larger species, and a desire to give to it as scientific a character as lay in my power, rendered necessary much technical detail. The present work, howerer, is proposed to be rather a pictorial illustration of the larger and more splendid species; and, as such, it is hoped, that, by finding its may to the table of the Indian drawing-room, it may gain additional conrerts to the study of a science 
full of curiosity, and awaken an interest in the objects of pursuit, thus supplying an engaging occupation to our Indian friends.

I cannot conclude this notice withont collectively thanking the several gentlemen who, by their practical exertions, have contributed so much to our knowledge of the Insects of India withiu the last few years, amongst whom it is a duty to mention the names of Colonel Hearsey, Major Jenkins, Captains Boys, Hutton, and Robinson; Drs. Royle, Horsfield, Templeton, Benson, and Downes; to all of whom I have been indebted for materials for the present work. I need scarcely add, that I shall be happy to receive any commnnications suited for the present work, from our fellow-labourers in India. Observations especially npon the habits and transformations of Indian insects are, indeed, highly to be desired; and all such, with which I may be favoured by correspondents, shall be faithfully acknowledged.

J. O. WESTWOOD.

HAMMERSMITU,

1st Jamuary, 1847. 



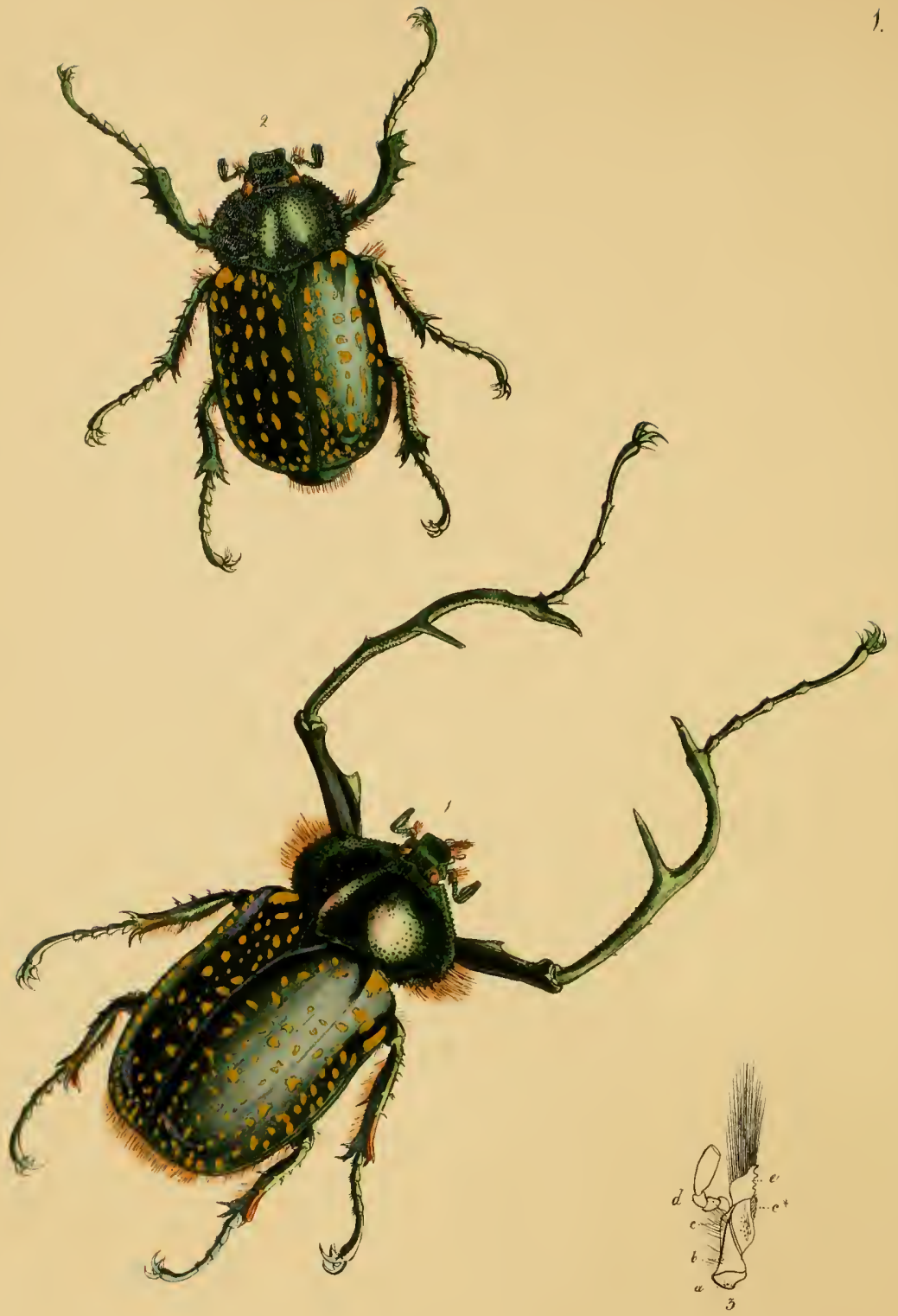





\title{
THE CABINET
}

OF

\section{ORIENTAL ENTOMOLOGY.}

\author{
PLATE I. \\ EUCHEIRUS (Cherrotosus) MACLEAII.
}

(Fig. I Male; Fig. 2 Female.)

(ORDER-COLEOPTERA. Secton-Lamellicorsia.)

\footnotetext{
Eucheirus reneo-viridis, prothoracis lateribus serrulatis et varioloso-punctatis, suleo longitudinali in medio dorsi fortiter impresso, elytris nigro-æeueis maculis fulvis insignitis, marginibus externis elevatis.

Euclieirus brassy-green, with the sides of the prothorax denticulated and deeply and irregularly punetured, having a deep longitudinal impression down the niddle, dilated bebind; the elytra brassy black, marked witl numerous fulvous irregular-shaped spots, and with the lateral margins elevated.

Length of the male $2 \frac{1}{2}$ inches; of the female nearly 2 inclies.

Inhabits the Assamese and Himalayan regions of India.

In the collections of the Rev. F. W. Hope, and Captain Parry.

Srionrmes.-Cheirotonus Macleaii, Hope, in Trans. Linu. Soc. xviii. p. 594, pl. 40, fig. 3 ; and Annals of Natural

History, vol, vi. p. 300, o.-Parry in ditto, Oetober, 1846. $\delta$.

Euchimes Maclerjanus, Burmeister, Handb. d. Ent. iii. p. 702 ; Genera Iusectorum No. 8, sub Euchirus, p. 2.
}

Description.-THE male of this most splendid addition to our knowledge of the Lamellicorn beetles of India, has the upper side of the body finely polished, especially on the disk of the prothorax, which is quite glossy, very convex above, and of a brilliant metallic green, tiuged with copper, and strongly punctured, the sides deeply serrated and clothed with long fulvous hairs on the under side; near each posterior angle is a deeply-sunk impression; the elytra are nearly black, with a brassy tinge, and with numerous bright fulrous spots of irregular form, which are disposed so as to form four or fire irregular longitudinal lines on each wing-cover. Under a lens the elytra are found to be entirely corered with exceedingly minute tubercles. The most striking character of the insect is exhibited by the fore-legs, which are disproportionately elongated and bent, the thighs with an acute appendage in the middle of the inner edge, the tibix subrugose with a rery strong and long spine in the middle, directed inwards, and another at the tip, at the extremity of which latter there is a small thick movable spur; the tarsi are also rery long, with strong bifid claws and with a small unguiculus terminated by two sete. On the outer edge of the tibire are two minute spines torrards the base, and another is slightly indicated 
near the tip. The four hind feet are robust, with the tibir strongly toothed in three separate series. The claws in these feet are formed as in those of the fore-legs. The entire under-surface of the body is brassy black, thickly clothed with mouse-coloured hairs; the front margin of the head is elerated, sharp and slightly denticulated.

The female, contrary to the usual rule among insects, is smaller than the male, agreeing with the latter in general colours and appearance, except that the wing-covers are of a greener tinge, the sides of the thorax not so much dilated, and the fore-legs of ordinary length, with broad flattened tibiæ, haring at least five strong teeth (varying, however, in number on the opposite legs of the same individual). In the only specimen hitherto known of this sex, the anterior margin of the head was not symmetrical, the right angle being more porrected than the opposite one.

The unique male* of this insect was received in a splendid collection from the Himalayas during the past summer, by H. G. Harrington, Esq., by whose direction an engraving of the insect was prepared, which has since been published in the Annals of Natural History, accompanied by a short note by Captain F. J. Parry, into whose rich collection it has now passed. The female was described by the Rev. F. W. Hope, in the Linnaean Transactions (rol. xviii. p. 594,) from a unioue female collected in Assam by W. Griffith, Esq., in the collection of R. H. Solly, Esq.

The ontline figure at the foot of the plate (fig. 3,) represents one of the lower jaws (maxillæ) of the male, highly magnified; $a$ being the cardo or basal hinge, $b$ the stipes, of a triangular form; $c$ the squama palpifera; $c *$ the mando terminated on the inside by a setose lobe; $d$ the maxillary palpus; $e$ the galea or upper lohe of the maxillæ, with short obtuse teeth fit for trituration rather than biting, and terminated by a very loug peucil of hair, as in the stag-beetles.

Observations.--India and the adjacent islands offer to us a striking peculiarity in respect to the geographical distribution of the gigantic species of Lamellicom beetles. Whilst the New ITorld is inhabited by a great number of these fine insects, (of which Dynastes, Hercules, and Elephas may be mentioned as well-kwown examples) the tropical oriental regions can boast but of few $\dagger$; these, however, are distinguished by their metallic or variegated appearance, of which their American brethren are destitute. Thus, amongst the true Dynastidæ we find Chalcosoma Atlas and its allies, to which we may add the fine species, Dynastes Hardwickii, and the singular species constituting the gemus Eucheirus, which in several respects seem to be the oriental representatives of the Golofie of the New World.

This group of insects lias much perplexed Entomologists as to its relations and consequent natural position amongst the Lamellicorn beetles. Fabricius, Olivier, \&c., arranged it with the Dynasticla. Mr. Hope, (Liun. Trans. xriii. 596) formed it into a separate family, Eucheiridæ, which he considered as "closely allied to the Dynastidæ and forming a sort of connecting link with the Goliathidæ." Drs. Klug and Erichson, (Proceedings of Berhin Academy, 1839; Wiegm. Archiv. Bericht, 1839, p. 28 (244); Taylor's Annals of Nat. Hist. No. 21, September 1839,) propose to place it at some distance from the Dynasticlæ and even after the gemus Cyclocephala, approaching Melolontha; whilst Dr. Burmeister (Zeitschr. d. Ent. 2, p. 353, and Handb. d. Ent. 3, p. 698,) refers it to the Trichiidæ.

\footnotetext{
* By information recently received from Captains Boys and Hutton, and Dr. Benson, I am induced to believe that other specimens of this insect, or of a nearly allied species liave lately been found in India.

+ The stag-beetles (Lncanidie) seem to occur in a reversed proportion in these two parts of the globe: the oriental species far exceeding, both in numbers and size, those of the New World. Thus Nature appears to restore the equilibrium by giving to each district a certain number of species possessing analogous properties.
} 


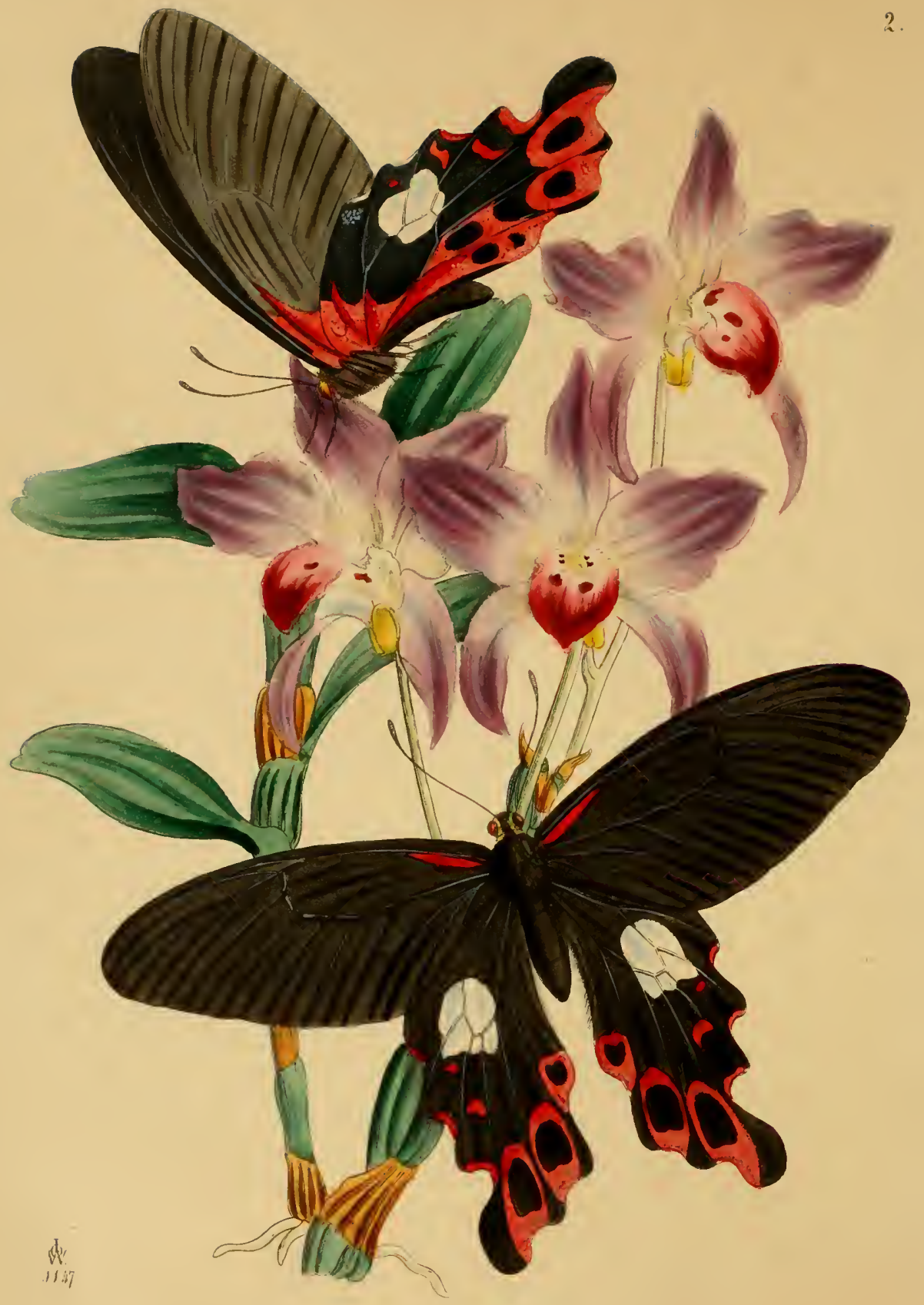






\section{PLATE II.}

\section{PAPILIO ICARIUS. WESTW.}

\section{(ORDER-Lepidoptera. Section Diurna. Rhopalocera, Bdv.)}

\footnotetext{
Papilio alis anticis supra fusco-nigris fasciis longitudinatibus nigris ; posticis valde elongatis et lilatato-caudatis, nigris, macula mediana alba, maculisque tribus magnis marginalibus rufis, inter eaudam et toarginem analem, maculas nigras includentibus ; alis subtus basi ctiam rufis; eapite et collari albido mactatis.

Papilio with the fore wings above brownish black, with black longitudinal faseire; the hiud wings much elongated and dilated at the candal part, above black, with a large white patch in the middle, and with thrce large red spots on the margin, hetween the tail and the abdominal elge, each bearing a black patch; all the wings on the underside have also their base broadly res, head and collar with pale buff dots.

Expansion of the fore wings, 6 inches.

Inhabits Assam. In the Aslimolean Museum, Oxford.
}

Description.-Is addition to the characters given in the abore specific description, it may be meutioned, that the fore wings have a red dash at the base; the white patch of the hind wings occupies the extremity of the discoidal cell, extending into four of the adjacent areas, and that the incisures on the outside of the tail are red : the two inner ones having between them and the discoidal white patch two small red spots; the red is of a brick colour, with a slight carmine tinge, and is irrorated with white scales towards the margin of the wing. (It may be observed, that the great red patches within the caudal extremity consist of the incisural and submarginal rows of spots confluent, so as to reduce the ground-colour of the wing between them to black insulated patches.) The underside of the fore wings is of a pale black, with a greenish hrown tinge, with slender longitudinal streaks; they; as wcll as the hind wings, have the base broadly saturated with a dark blood-red colour with white irrorations, insulating two black patches between the black anal spot and the white discoidal spot. The ground-colour of the hind wings is jet black; their outermost area has a small patch of blue scales towards its extremity, and the preceding area has a small red dot ontside the white one.

Observations.-Assam appear's to be pre-eminently rich in the species of Papilio, A number of new species, from this region and the neighbouring district of Sylhet, were figured in my "Arcana Entomologica," but none of them will bear comparison with the present insect, either for size or singularity of form, owing to the extraordinary elongation of the hind wings and the short dilated tails. In its general appearance it bears some resemblance to P. Bootes, Westw., (Arc. Ent. 1, pl. 31,) especially in the red base of the wings on the underside; but the colour of the spots of the head, neck, and underside of the body are different, agreeing, in the latter respect, as well as in the white central patch of the hind wing, with P. Helenus. The specimen figured is nnique, and is contained in a Collection of Assamese Insects lately presented to the Ashmolean Museum, at Oxford. 
Adopting the excellent system of Nomenclature proposed with so much taste by Linnaus, whereby the species of the modern genus Papilio were distinguished by the names of the famous heroes of antiquity, the present species (in order at the same time to indicate its relation to Papilio Bootes) is named after Icarius, the son of CEbalus and Erigone; who, having been killed by some peasants of Greece, whose companions he had made drunk with wine, (a liquor till then unknown to them, and which from its effects they thought to be poison,) was transformed by Jupiter into a star, which was supposed by some persons to be identical with the celestial Bootes.

The Orchidaceous plant figured in the plate is the Dendrobium monileforme of Linnæus, lately sent by Dr. Wallich, to the Royal Gardens at Kew. 



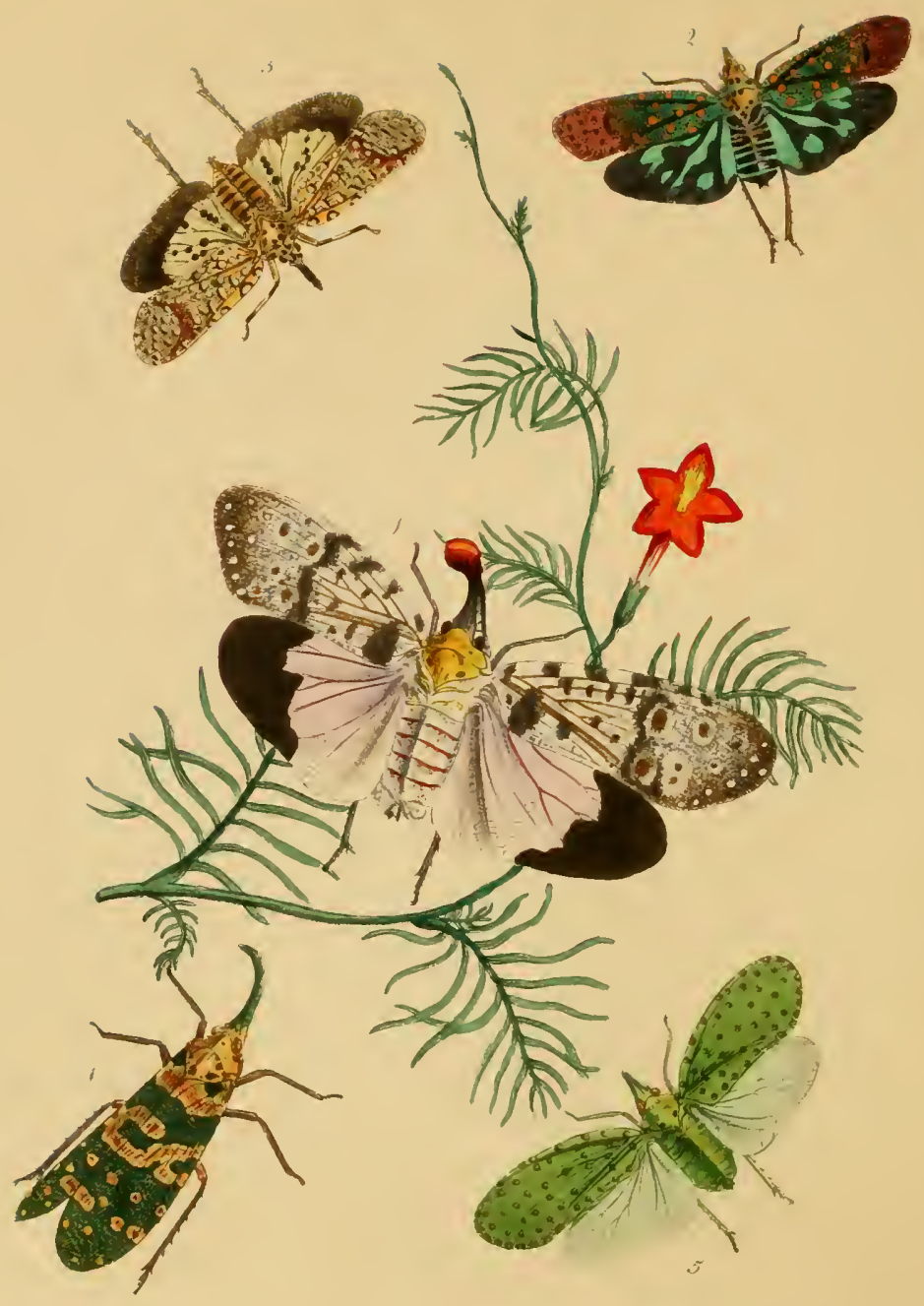






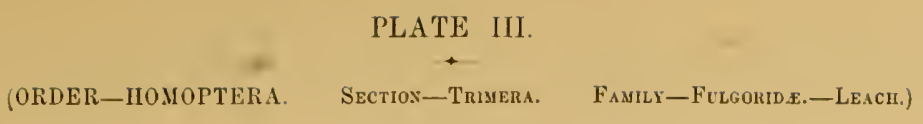

FIGURE 1

FULGURA (HOTINA) CLAVATA. WESTW.

\begin{abstract}
Fulgorn rostro corporis dinidii longitudine, jiceo, ajice in ghobum subrotumdum testacen dilatato; hemelytris basi suballidis, fuseo-naculatis, apice fuseo albido-ocellatis et maculatis; alis subpurpureo-ulbidis apiee late fusco ; corpore albo-farinoso.

Fulgora with the rostrum about half the length of the boty, of a pitehy colour, the apex dilated into a shining testaceous globe, the hemelytra very farinose, with the hase of a pale butf colour with pitehy brown spots, and the extremity brown with white rings and dots; the unter wings pale dull purple, (which fades into pate buft) with a broal brown apex, the body very thickly elothed with white powder.

Length of the body (with the rostrum) 11 inch. Expansion of the lemelytra 3-31 inclies.

Iuhabits Assam. In the eollections of the Britisls Mnseum, Hope, Cantor, Westwood.

Srx.-Fulgora elavata, Westw, in Linn. Trans, xviii, p. I39; pl. 12 ; fig. 1.
\end{abstract}

DEscriptiox.-MY original figure and description of this species having been madc from a small faded specimen, I herc present the reader with a figure of the species in its fresh state, in which it is very densely covered with the white powder which is secreted by many other Homopterons insects. The rostrum is dotted with this farinose secretion, the upper side of the thorax is fulvous, and the upper surface of the abdominal segments (where uncovered by the white powder) is bright red; the legs are black, except the posterior femora, which are pale fulrous. I am indebted to the Rev. F. W. Hope for the specimen figured.

OвsеRvations.-Much interest has attached to the insects of this curious genus ever since the period when the celebrated Madame Merian published her statement that the large American species (Fulgora laternaria) possesses the power of emitting a strong light from the dilated anterior part of the head. No subsequent traveller or author of credit appears to have observed the least traces of luminosity in this species, although it is far from rare in some parts of South America. Messrs. Lacordaire, Richard and Hancock, all of whom had opportunities of examining the living insect, failcd in detecting any emission of light, and their statements have been confirmed to me both by the late lamented Prince Maximilian of Nieuwied, and J. Miers, Esq., whose long residence in Brazil and fondness for entomological pursuits afforded to both abundant means of observation. As regards the oriental species (althongl one of them was represented by Donovan as emitting a strong radiating light from its rostrum,) I cannot find a single authority for their luminosity; and Dr. Cantor, who was engaged in the late Chinese expedition (and by whom the first specimens of the species here figiu'ed were transmitted to Europe,) has informed Mr. Hope that he nerer observed the slightest luminosity in the common Chinese F. Candelaria. Whether the species may not at certain periods of the year become, or whether either of the sexes may not be, luminous, is still, howerer, a question for inquiry, especially as its existence lias lately been re-asserted.

FIGURE 2.

\title{
FULGORA (HOTINA) GEMMATA, Westw.
}

Fulgora eapite thoraceque fulris nigro-maculatis; abdomine nigro, segmentorum apicibus viridibus ; hemelytris basi viridibus, apice obscure brunneo rufis; nigro-punctatis et aurantio-guttatis; alis posticis viridibus apice late maculisque oblongis nigris.

Fulgora with the head and thorax fulvons with black markings; the abdomen black with the extremity of the segments narrowly green; the hemelytra are green at the base which gradually changes into a dark browuish crimson, they are entirely covered with minute black dots, each being ornamented witls about 30 hright orange spots ; the hind wings are green, with a broad black border, which extends into the disk of the wing, forming several large black blotches ; the legs are dark red.

Length of the body (exelusive of the rostrum) s inch. Expansion of the hemelytra $2 \frac{1}{8}$ inclies.

Inhabits the Himalayan range. In my own Collection. 
Observation,- The front of the rostrum of the unique specimen of this species in my collection is unfortunately injured, so that its precise form cannot be given. I am indebted to H. G. Harrington, Esq., for this beautiful and nondescript addition to the genus.

FIGURE 3.

FULGORA (HOTINA) GUTTULATA. Westw.

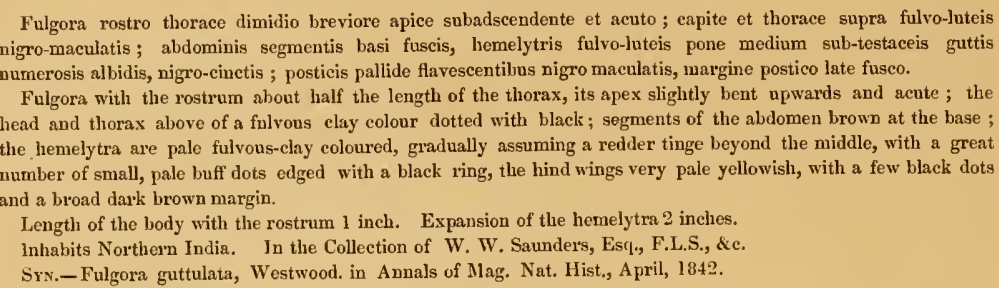

Description.-The promuscis in this pretty species is very long and slender, cxtending to the extremity of the body, the cliccks are separated from the rostrum by a transverse raised line, between which and the eyes is a black dot. The four anterior legs have a black ring at the base of the tibix, the apex of which and the tarsi are also black, the underside of the body and the hind legs are entirely fulrons, with two small black spots at the base of the coxæ, and two long black spots at the sides of the penultimate abdominal segment.

\section{FIGURE 4.}

\section{FULGORA (HOTINA) VIRESCENS. WESTW.}

Fulgora rostro brevi conico vix adscendente; pallide virescens prothorace et mesothoracis sentello utrinque puncto nigro ; hemelytris latis costa curvata, maculis numerosis parvis fulvis ornatis; posticis virescenti hyalinis.

Fulgora with a short conical rostrum scarcely bent upwards; entirely pale green, with a minute black spot on each side of the prothorax and scutellum, the liemelytra broad with the fore margin much arched, green with numerous small rounded orange-coloured spots, ontwardly edged with black, hind wings very pale green and semitransparent.

Length of the body and rostrum $\frac{3}{4}$ inch. Expansion of the hemelytra $2 \frac{1}{4}$ inches.

Inliabits Sylhet. In the Collections of the Aslımolean Musenm, and Messis. Hope, Leadheater and Westwood.

Syn.-Fulgora vireseens. Westw. in Anuals and Mag. of Nat. Hist., A pril, 1842.

Observation.-I am indebted to the Rev. F. W. Hope for the specimen here figured.

\section{FIGURE 5 .}

\section{FULGOLA (HOTINA) VIRIDIROSTRIS. WESTW.}

Fulgora rostro thorace dimidio longiore apice adscendente et acuminato, viridi farinoso-guttato ; corpore fudvo thorace nigro maculato, pedibus vigris femoribus posticis fulvis, hemelytris et alis ut in $\mathrm{F}$. candelaria coloratis.

Fulgora with the rostrum abont half as long again as the thorax, with the apex turned up and acuminate, of a dark green colour with white irrorations; the body fulvons, with the thorax spotted with black; the feet black with the four anterior femora pitchy, and the two hind femora fulvous; the hemelytra and wings coloured and marked as in F. candelaria.

Length of the body and rostrum $1 \frac{1}{4}-1 \frac{1}{2}$ inch. Expansion of the hemelytra $2 \frac{1}{2}-3$ inches.

Inhabits Assam. In my Collection.

Observations.-I am indebted to Major Jenkins and Captain Robinson for my specimens of this species, which in general character closely approaches Fulgora Candelaria, from which, however, it is at once distinguished by its much shorter green rostrum and the dark colour of the legs. I have received so many specimens, agreeing together, as to leave no doubt of its distinctness from the species last named, of which, however, it seems to be the geographical representative. 



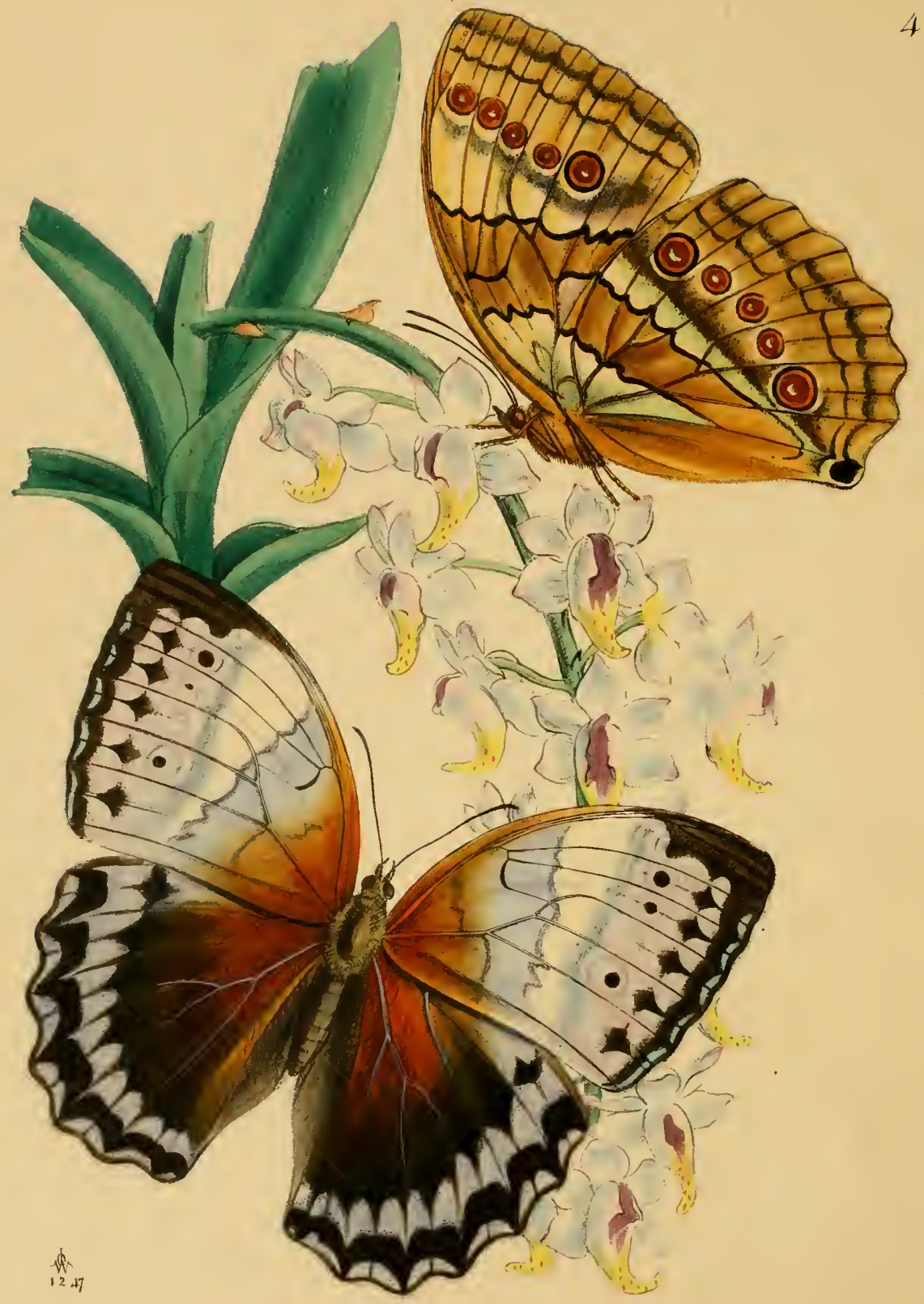






\title{
PLATE IV.
}

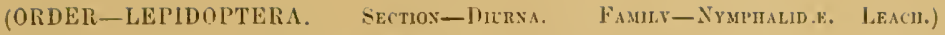 \\ MORPIO (TILAUMANTS) CAMADEVA. Wr.tW.
}

\begin{abstract}
Morpho alis antieis supra albis plumbeo-eceruleo tinetis, basi brunneis, fascia sulmarginali macularum alteraque lunularun fuscis; alis posticis fuscis basi brmuneis faseia hundarum plumbeo-allarum pone medium ; alis infra basi albidis apieibus fulvis, fascia lata comunui lulva utrinque linea nigra cincta aute medium alarum, oevlisųue 5 (in singula ala) rubris iride nigra, pone medium, strigisque dualus sul)marginalibus paliide fuscis.

Morpho with the fore-wings above of a white colour, tinged with a delicate purplish leaden colour, blie base of a rich brown ; with a row of lozenge-shaped spots and anotluer of brown continuous lunules near the outer margin ; the hind wings brown, the basc of a richer eolour; eonsiderably beyond the middle is a row of large leaden-white lunules, and a smaller row elose to the margin ol the wings; on the under-side the basal portion of the wings is of a delicate luft with a slight greenish tinge, nnd the apical portion fulvous; a broal irregular fulvous laseia runs across all the wings before the middle, elged on each side by a black line, and beyond the middle, each wing las a row of five red eyes with black irides, beyond which are two pale-lown continuous faseice.

Expansion of the fore wings $4 \frac{1}{2}$ inches.

Inlabits the Himalayan district of India.

In the Collectious of the British Museum, the East ludia House, and H. G. Harrington, Esy.
\end{abstract}

Descriptios.-The three or four round brown spots preecding the rows of lozenge-shaped marks near the extremity of the fore mings, occupy the place of the eyes of the underside; and the broad row of white lumules on the under wings, is the continuation of the pale space betwecn the lozengeshaped spots and row of lunules of the fore wings; since, in a strong light, the dark ground-colour of the hind wings also exhibits a row of still darker-coloured lozenge-shaped spots, preceding the pale lumules.

On the underside of the wings the broad fascia is dilated on the anterior half of the wing, so as to include lialf of the discoidal cell and the like distance beyond it, inclosing a black lumule which marks the vein which closcs the cell; the eyes are preceded by a longitudinal darker clond; the larger eyes bear a slcuder white central lunule, and the red pupil is separated from the black iris by a fulvons ring; the anal angle is marked with a black spot, ontwardly edged with white. The npper side of the body is brown, but the under side, with the palpi, legs, and anal area of the hind wings, are fulrous.

Onservatioss.-As it is proposed in a future number to make some observations on the distribution of the veins of the wings of Lepidopterons insects, I shall here describe the position of those of the fore wings in the species before us. The costal rein extends close to the fore margin of the wing for two-tliirds of its length, where the rein joins the margin. It is closely sncceeded by the suls-costal rein, which emits three branches, the first springing from it at a little distance preceding the extremity of the discoidal cell, and joining the fore margin just in front of the base of the first eye-shaped spot; the second bianch is short, rumning in front of the first eye; the third branch rises close to it and extends exactly to the tip of the wing; after throwing off this third branch the sub-costal rein itself extends to the outer margin of the wing, a little distance below the apex. Halfwar betwcen the two 
black edges of the fulvous fascia of the fore wings is seen a black streak, which marks the place of a very short oblique vein, (which shall be designated by the letter $a$ ) a very short transverse one $(b)$, and a curved one $(c)$; from the angle formed by the junction of the oblique and transverse ones, there extends a vein $(d)$, which runs to the onter margin of the wing, and from the angle formed by the junction of the oblique and curved veins another longitudinal vein $(e)$, extends to the onter margin. The great median vein has three branches, which inclose between them the two eyes nearest the hind wings. The third of these branches is a good deal elbowed, and it throws off near its base, at a rery obtuse angle, a straight but very oblique vein $\left(c^{*}\right)$, which joins the extremity of the curred one $(c)$. Between the third branch of the median vein and the longitudinal vein $(e)$, there is a strongly markcd kind of a folding of the wing. The discoidal cell is traversed by three delicate lougitudinal veins; the first joins the sub-costal one, close to the origin of the first sub-costal veinlet, the second joins the curved vein $(c)$ near its junction with the short transverse vein $(b)$, and the third at the junction of the curred rein $(c)$ and the vein $\left(c^{*}\right)$ springing from the third branch of the great median rein. The submedian or anal rein is slightly curved at its base.

I am indebted to H. G. Harrington, Esq., for an opportunity of figuring this new and splendid Indian butterfly, which I have dedicated to the Indian god of love, Camadeva, celebrated in Moore's lines :-

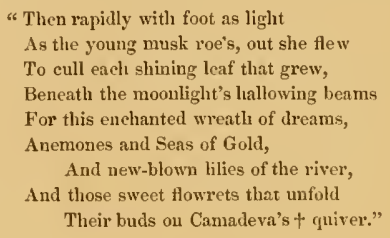

LALla Rookн.

It is impossible to look at the markings of the wings of this beautiful insect, and of many other species of the family to which it belongs, without being reminded of the strong resemblance which exists between them and the very characteristic markings of the peacock, and other allied tribes of birds. Mr. Swainson allndes to this analogy in the following passage :- "The strong peculiarity which muns through all these gromps, is that the under surface of the wings is invariably omamented with beantiful ocellate spots; these spots, in the large American species, resemble in form, but not in brilliancy of colour, those on the tail of the peacock; but in the European examples they are smaller, more numerous, and often silvery. The general structure of all these insects, eren those of the largest, is weak. The typical groups [Morpho, \&c.] live only in the dark primeval forests, resting on the trunks of trees, during the meridian heat, and show a decided partiality for shade; some, indeed, fly only in the dusk of the evening." $\neq$

+ "This tree (the Nagacesara) is one of the most delightful on earth, and the delieious odonr of its blossoms justly gives them a place in the quiver of Camadeva, or the God of Love." - Sir W. Joncs.

‡ History of Insects, p. 93. 



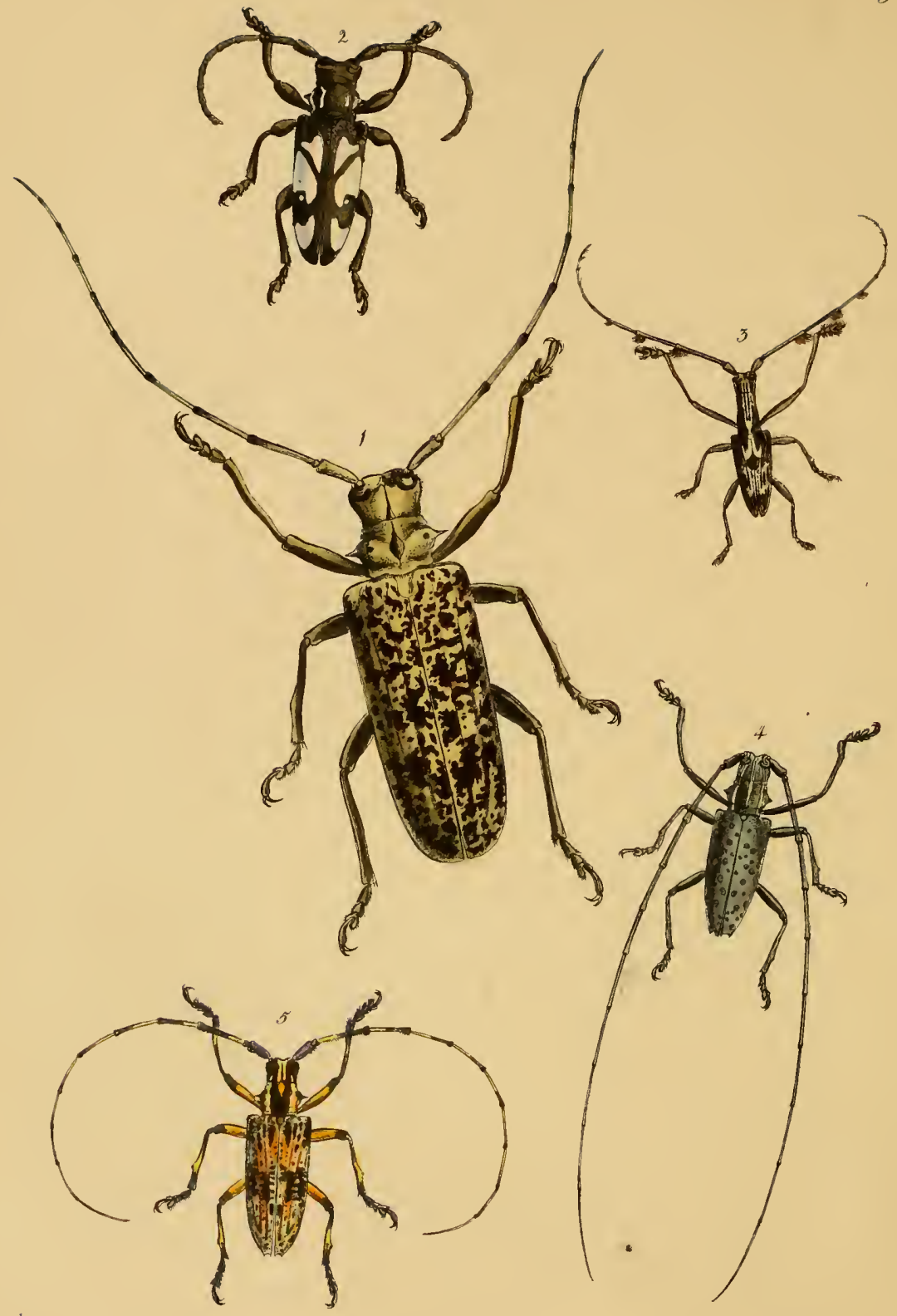




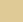


PLATE V.

(ORDER-COLEOPTERA. Sectios-Loxgiconnes, Fanily-C'eramiscid.e. Leach.)

OBseirations.-The Longicorn beetles of the East, although not equal in size to those of the tropical regions of the New World, yet comprise amongst their numbers many large and beautiful species; in fuct their "mission," in uature, requires that a great preponderanee of liguivorous insects should exist in those portions of the globe. The great majority of the species reently bronglit from India are new; and of these some very splendid kinds have been lately deseribed by the Rer. F. IV. Hope, in the "Limican Transactions," collected by the late Mr. Griffith, in Assam. Several of" the fine species represented in the accompanying plate were receired from the Himalayan range during the past summer, and are now in the rich collection of $\Lambda$. Melly, Esq., of Liverpool, whose munuseript names I liare much pleasiure in adopting in this work.

FIGURE 1.

IIAMMATICIERUS MARMORATUS. MELLY, MS.

Ilammaticlicrus obseure lutco-griseus, prouoto macula media punclisque duobus minutis lateralibus nigris nitidis ; elytris maculis gultisque numerosis irregularibus fuscis ; antennis apicibus articulorum nigris.

llammaticherus entirely of a dull and dirty luteous grey colour; the pronotum with a eentral diamond spot and two small lateral dots of polislied black; the elytra covered with numerous irregular-sized aud shaped brown spots and dots; and tlie antenne with a black ring at the extremity of each joiut (except those at the base and extremity).

Leugth of the insect $2 \frac{1}{2}$ inches. Breadth of the base of the elytra $\frac{4}{3}$ incli.

Inlabits the Himalayan region.

Description.-The mandibles are black and polished; the back part of the head has a polished patch, corresponding with that of the pronotum. Eacli clytion has two prominently elerated lines on the disk, and the tip round and unarmed; the sterna are quite simple. The under-side of the body and legs are corered with the same dull relvety coating which appears on the upper side of the inseet.

FIGURE 2 .

PHRYNETA MARGARITIFERA. MELLy, MS.

Phryneta fusco-velutina, pronoto lineis duabus lateralibus albis, elytrisque maculis sex magnis irregularibus margaritaceo-albis; pedibus incrassatis.

Phryneta of a velvety brown colour; the sides of the pronotum with two white lines and the elytra with six large irregular-shaped patelies of a pearly white colour ; the legs incrassated.

Length of the body $1_{4}^{\prime}$ inch. Brcalth of the base of the elytra $\frac{1}{2}$ inch.

Iuhabits Nepaul. In the Collections of the Rev. F. W. Hope, A. Melly, Esq., and my own.

Description.-The entire insect is clothed with a fine relvety pile, with the base of the elytra rather eoarsely punctured. The parts of the mouth are rery short, the eyes strongly incised at the base of the antenixe, which are rather short and thick, as are also the spines at the sides of the pronotum. This part of the body has two white lateral lines on each side, and the elytra have six large pearly-white spots, of irregular form, besides two minute white dots. The stcrna are simple; and the legs (especially the femora) are thickened. The tips of the elytra are unarmed.

The specimens in my collection, presented to me by the Rer. F. IT. Hope, are smaller than the one figured, and have the sides of the pronotum occupied by a large white oblong patch instead of two lines, as in Mr. Mellỵ's specimen.

\section{FIGURE 3.}

\section{GNOMA? PLUMIGERA. Meli, MS.}

Gnoma antennarum articulis 3 , 4, et 5 scopiferis ; fusca, capite et pronoto supra albo et nigro lineatis, elytris striolis maculisque variis albis et nigris variegatis, niacula majori ad suturam ante medium elytrorum posita, prothorace elongato lateribus incrmibus.

Gnoma with the $3 \mathrm{rd}, 4 \mathrm{th}$, and 5 th joints of the antennse furnished with a tuft of black hairs at the tip, behind ; 
dark brown ; the crown of the head and back of the pronotun with three slender lines in the middle, which eonverge together near the scutellum (which is white); the elytra are varied with a number of dirty white and dark-brown lines and oblique patches, especially a larger diamond-shaped dark-brown spot on the suture before the niddle of the elytra, edged with a dirty white; the prothorax is elongated with the sides, not spined.

Length of the insect $\frac{2}{10}$ inch.

Inhabits Java. In the collectiou of A. Nlelly, Esq.

Description.-The terminal joints of the antenne have alsu a very small tuft of hairs within, those on the last joint being placed in the middle, so as to give the appearance of there being twelve joints. In addition to the markings above described there is a slender whitish line on each side, which extends from the eyes to the tip of the elytra, and another in front of each fore-leg; the sides of the breast and abdomen are also marked with slender lines of the same colour. The fore-legs are loug, the tibia rather crooked, and the fore tarsi dilated and hairy; the elytra are rounded and simple at the tips. The prosteruum is arched, and extends narrowly between the fore coxr, without any prominent angle, the mesosternum forming a very slightly porrected angle. This insect departs from the typieal form of Gnoma, to which genus it is nearly allied. There are tro undescribed Javanese genera introrluced into De Jean's catalogue, with plumose antenna; the first, Imantocera (Cerambyx plumosus, Oliv.), is much nearer to Lamia than the present insect; the other is named Psectrocera scopulicornis, Dej. It is impossible for me to determine whether it be identical with the insect here figured.

FIGURE 4 .

Monohames PUNCTUlatus. MeLL, Mis.

Monohammus plumbeo-grisens, capite et pro-thorace albo lineato; elytris gut tis numerosis rotuudatis albis; pectoris et abdominis lateribus albo-maculatis ; pronoto transverse striolato.

MIonohammus of a leaden-grey colour, the head and protlsorax marked with white longitudinal lines, the scutellum white, and the elytra marked with numerous small white round dots of various size; the sides of the breast and aldomen also spotteu with white; the pronotum is transversely striated.

Length of the insect $I_{\frac{1}{8}}$ inch.

Inhabits the Himalayas. In the Collection of $\mathbf{\Lambda}$. Melly, Esq.

DEscription. - The face is marked with two short white strokes, and there is an oblique one behind the lower part of each eye; the upper part of the head and the pronotum are marked with three longitudinal white lines; the middle one terminating in the scutellum, which is white, and the side ones in a short oblique white dash on the shoulder's of the elytra, which latter are truncate at the tips, the angles of the incision being slightly produced. The prosternum is simple, but the mesosterum is porrected and forms a right angle when seen in profile.

FIGURE 5 .

MONOH.AMMUS WESTWOODII. MELr, MS.

Monolammus albido, luteo et nigro variegatus, pronoti medio (macula ovali pallida antica inclusa) lateribusque nigris ; elytris fascia irregulari maeulari (in medio sub-intermupta) nigra, femoribus tibiisque annulo medio lnteis.

Monohammus variegated with buff, clay-eolour and black, the pronotnm having the middle and sides black, the former inclosing an oblong pale spot in front ; the middle of the elytra with a broad irregular faseia formed of confluent black spots, interrupted next the suture ; the femora are buff in the middle, and the middle of the tilix lias a ring of l.uff.

Length of the insect $1 \frac{1}{4}$ inch.

Inhabits the Himalayas. In the Collection of A. Melly, Esq.

Description.-The face is black, with two buff lines, a large patch of buft on each side between the mouth and eres. The antenne are black, with the base of the third and following joints pale buff. The two lateral spines of the prothorax are rery acute. The base of the elytra is slightly rugose, and the disc is raried with four longitudinal clay-coloured lines on each elytron. The tips of the elytra are bispinose. The breast is pale buff, and the abdomen is varied with four rows of spots, of the same colour. The tarsi are black, with pale cushions. 



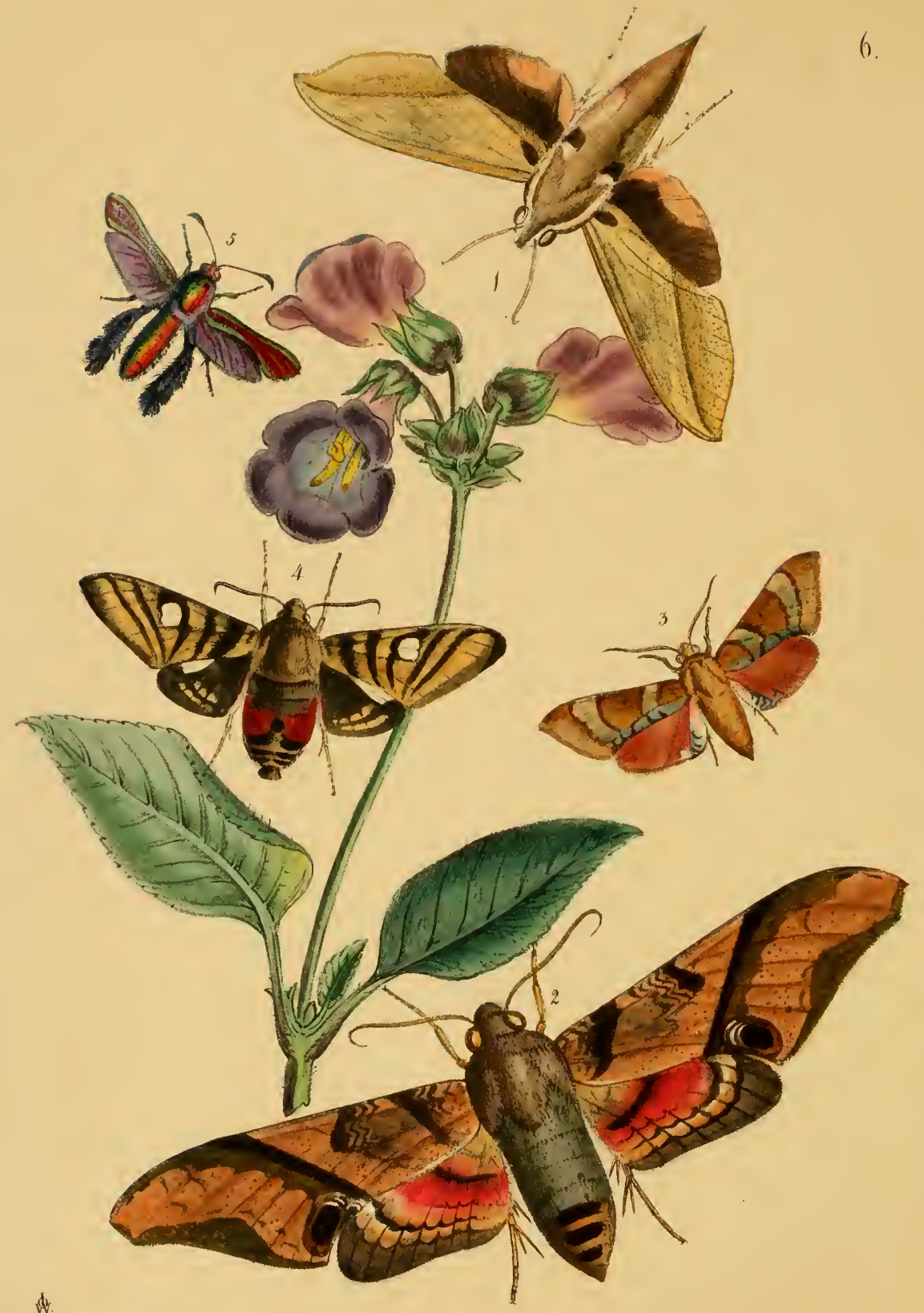





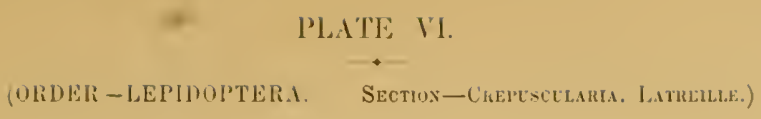

PIGURE 1.

DEILEPHIL.I CYRENE. WESTW.

\begin{abstract}
Deilephila alis anticis ulivaceo-albidis, nubila media ohseuriori punctoque minuto ordinario, strigaque fusc; $e$ medie marginis interni al apicem ; posticis nimo-fuscis, angulo anali late albido; capitis ct thoracis lateribus abo-lineatis maculisque duabus nigris al basin ablomiuis.

Deilephila with the fore wings of an olive butf, darker along the eosta, aud with a lusky eloud in the midlle, close tu which is a very ninute dark dot, a dark patch at the base of the inner margin, and a nearly straight dark streak from rather beyond the midlle of the inner margin to the tip of the wing (preeded by two or three vory indistinet dusky streaks, and followed by a dark olive-brown spaee; the hind wings are black-brown, with the anal angle broadly luff with a slight rosy tinge ; body olive-brown, with a white stripe at the sides of the latal and thorax, and with two black spots at the liase of the ahdomen.

Expransion of the fore wings $3 y$ inches.

Inlabits Central India and Ceylon. In the Collections of Col. Henrsey and Dr. Templeton.
\end{abstract}

Descuption.- The antennæ, as well as the under-side of the head and breast, are pale whitish bufl, with a slight rosy tinge, which also appears on the pale sides of the head. The abdomen is rery long and pointed at the tip; the sides belind the black spots paler than the back. The legs arc pale buff; and the eosta of the fore wings is edged with fulrous.

The species is rery closely allied to D. Noma, but differs in the oblique streaks of the fore wings and the extent of the pale anal spot of the hind ones.

FIGURE 2.

SMERINTHUS ? PANOPLS, (Cramer, iii. p. 50. Pl. 224, Fig. A 13.)

\begin{abstract}
Smerintlus (?) alis antieis roseo-fulvis, fascir composita fusca versus basin altetanne angulata media, postice obliteratis ; fascia recta obliqua pone medium maculaque subocellari ad angulum ani nigra ; alis posticis in medio roseis lineis duabus undatis fuseis pone medium fimbriaque obscuris.

Smerinthus? with the fore wings fulvous, with a rosy tinge; laving near the base an ollirue dark-brown fascia (composed of two narrow and one broader stripe); another similarly composed but mucli angulated near the middle of the wing (both being obliterated belind) ; a straight oblique dark brown fascia bevond the midtle of the wing, tetminated in a large black, somewhat ocellated spot at the anal angle ; hind wings rosy in the midlle, witlı two narrow festooned dark lines beyond the middle, and a broad dark border.
\end{abstract}

Expansion of the fore wings nealy 6 inches.

Inhabits Assam and Sylhet. In my own aud the British Museum Colleetions.

Descimption.- This fine species has the head and thorax dark-Jrown, the basal portion of the abdomen pale-grey, and the terminal segments fulrous, each with a dark-brom patch. The antenus are slender and curved at the tips, the extremity of the fore wings is obliquely truncate, bchind which the apical margin is ncarly straight. The oblique fascia of the fore wings is followed by an olive-brown spaee, of which colour there is also a large angulated patch on the apical margin; the spurs of the hind legs are remarkably long.

I am indebted to Major Jenkins for my specimen of this species, which differs materially from the typical Smerinthi; but as Dr. Boisdural is at present engaged upon a revision of the Sphingida, I have alstained from forming it into a new genus. Stoll's specimen was from the North Coast of Java.

FIGURE 3.

SPHINX ORNEUS, WEST,

Sphinx alis anticis einereo-fulvis, striga prope basin, faseia lata media brunneu-fulva strinaque arenata pone medium ; margine interno cinereo maculis 5 nigris, alis postieis roseis, angulo auali cinereo strigis parvis nigris.

Sphinx with the fore wings fawn-coloured or ashy tulvous, a slender red-browi transverse eurved streak near thite 
base, followerl by a very broad red-brown faseia across the middle of the wing, inclosing a dark-brown dot; and beyond this is a waved dark streak across the wing (bearing black dots on the veins) the internal margin ashy, with 5 black spots; lind wings rosy, with the anal angle ashy and bearing several short black dashes.

Expansiou of the fore wings $2-2 \frac{1}{4}$ inches.

Inhabits Central India. In the Collection of Col, Hearsey.

Description.-The antemmx in the male are rather long, and very pale buff-coloured; the head and thorax are red-brown; the abdomen paler; the anterior tibire are terminated by a strong curved horny spine. All the wings on the under side are rosy-fulvous; the fore ones with one, and the hind ones with three, red-brown streaks crossing them.

\title{
FIGURE 4.
}

\section{MACROGLOSSA TRIOPUS. W Estw.}

\begin{abstract}
Nacroglussa alis anticis fuseis, fasciis 5 fimbriaque apicali nigris maculaque media subquadrata vitrea; alis posticis nigris macula costali allba margineque anali roseo; abdomine nigro, fascia (in medio interrupta) leete rosea.

Maeroglossa with the fore wings greyish brown, with five black transverse fascize and a dusky apical margin ; in the middle, towards the costa, is a vitreous, nearly square spot; the hind wings are black witl a broad white costal patcl, ani a rosy anal margin ; the abdomen black, with a splendid rose-coloured fascia, interrupted in the middle.

Expansion of the fore wings 3 inches.

Inlabits Assam. In my Collection.
\end{abstract}

Description.-The antemuse are short, sleuder, and elbowed at the tip; the body is very robust; the liead and thorax brown; the latter appears to have four longitudiual ill-defined white streaks. The sides of the terminal segments of the abdomen have tufts of fulvous scales. The body beneath is rosy, with black articulations; and the hind wings are also of a rich rosy colour, witl'two narrow transverse fascire of black.

Observations.-I liave litherto seen but one specimen of this very singular species, communicated by Major Jenkins, from Assam. The contrasted coloms and the two talc-like patches on the wings must render this species a rery elegant object during flight and horering orer a flower, as is the habit of the species of the gemus to which it belongs.

\section{FIGURE 5.}

\section{TROCHILIUM ASHTAROTII, WESTW.}

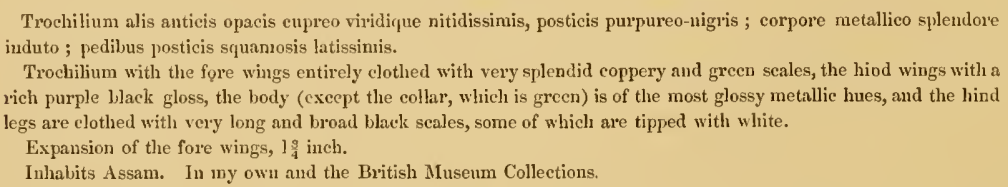

Description.-The antemne are very slender, except towards the tip, where they are dilated into a thick club pointed at the tip. The palpi are slender, conical, and porrected. The front of the thorax (except the collar) is of the most intense fiery copper. The extremity of the hody does not appear to have been furnished with a fan-like tail, as in the smaller species of the family Trochiliidæ.

Observations.-This species, from the extraordinary metallic brilliancy of its colours, must be considered as one of the most rcmarkable of the insects of the family Trochiliida, to which it belongs. Indeed it is impossible, on inspecting it, not to call to mind the humming-birds, of which this is perhaps one of the best analogies; we have here, in fact, not only the metallic colours but the tufted legs which renders some of the humming-birds such remarkable objects. I am indebted to Major Jenkins for this brilliant insect.

The plant represented is the Chirita zeylanica. 


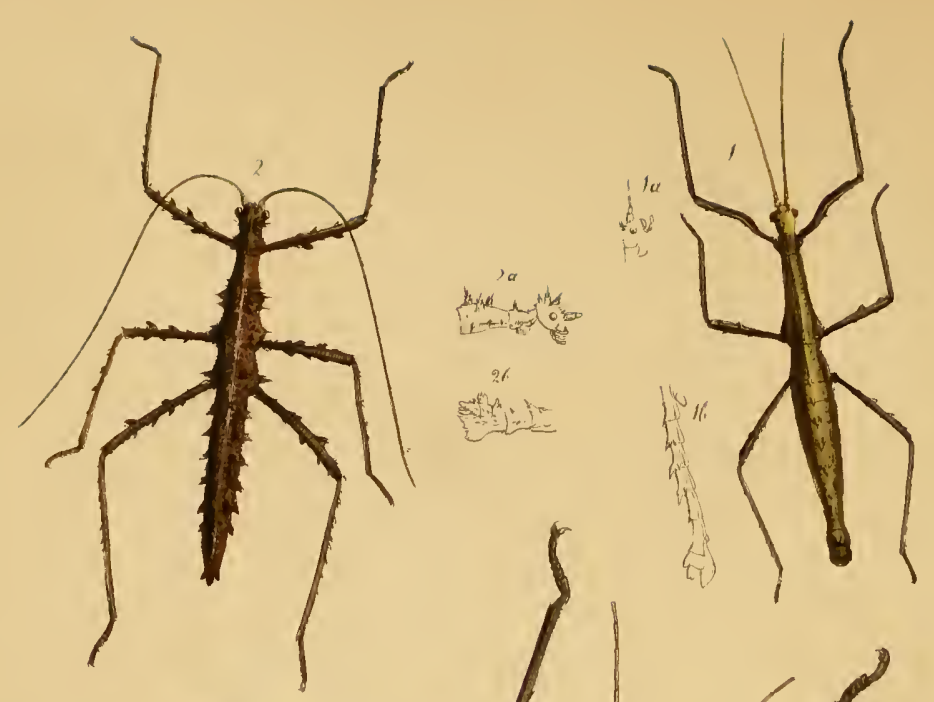

$\%$

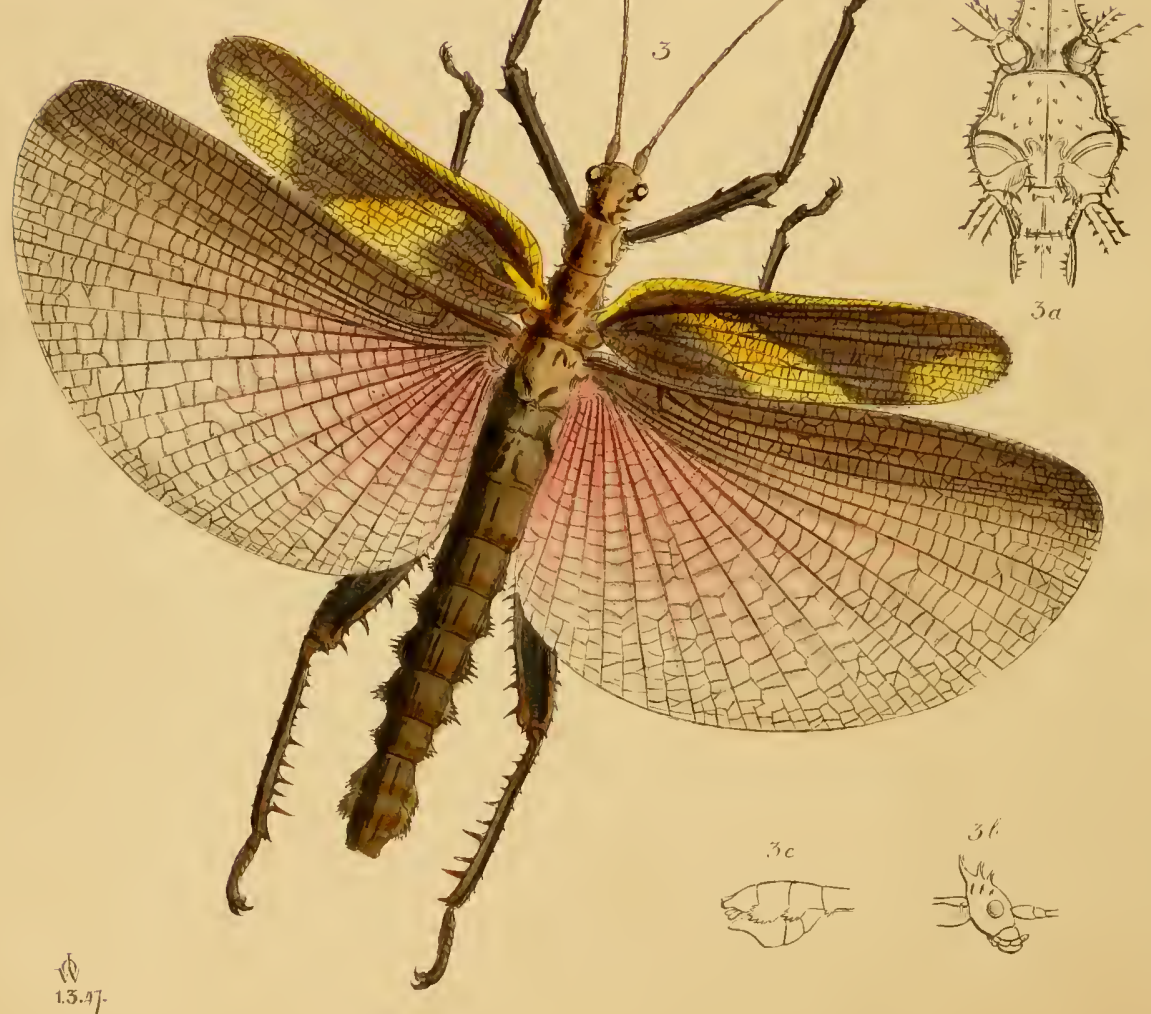






\title{
PLATE VII.
}

(ORDER-ORTiloptera. Section-Aybrlatoria, Family-Phasmid.e.)

FIGURE 1 .

PHASMA (ACANTHODERA) SEMI-ARMLATA. Westw.

\begin{abstract}
Phasma aptera luteo-fusea, squalida, subgranulosa, enpite spinis duabus inter oculos, metanoto et ablominis segmentis 4 basilibus spina reflexa acuta in nedio marginis postiei, femoribus omnilus lobis parvis angulatis instructis.

Pliasma wingless; of a dirty elay-brown colour, opaque and slightly granulose; the head armed with two small spines between the eyes; the middle of the hind margin of the metanotum and four basal segments of the abromen armed witl an acute reflexed spine (dilated at its base) ; all the femora furnishect with small-angular lobes.

Length of the body 2 inches.

Inlabits the Ilimalaynn range. In my own Collection.
\end{abstract}

DescrıPton.-The head (fig. $1 a$ ) is armed with two small spines. The antenne appear ouly to be lalf the leugth of the body. The hind part of the thorax (between the hind feet) and the base of the abdomen sue dilated, the latter becoming gradually narrower to the sixth joint; the three terminal joints are orate, with a small erect lobe in the middle (fig. $1 a$, the abdomen seen sideways); besides the lobes of the femora, the tibire possess sereral minute prominences. I am indebted to H. G. Harrington, Esq., for this species.

\section{FIGURE 2.}

\section{PIASMA (ACANTHODERA) BICORONATA. WEST. Stenésepe}

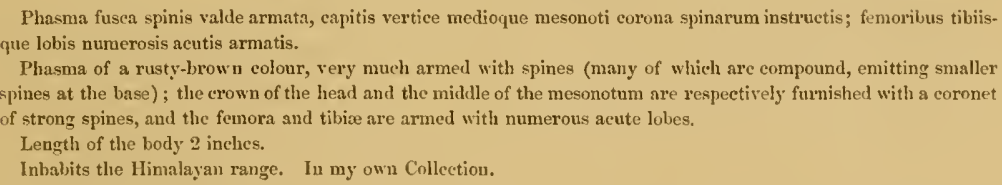

Description.-This ugly inseet, with its strangely-spined coating, recalls to mind some of the must lideous of the reptile tribes. The antemure are nearly as long as the body, with the articulations more distinctly marked than in the last species, the middle joints being considerably longer than the basal ones. Besides the spines forming the two coronets (fig. $2 a$, whence I have derived the specific name), the abdomen has a double series down the back, as well as a row on each side.

The $i$ th and sth abdominal segments have an elevated tubercle in the middle of the back, and the anal plate is rery much angulated in the middle of its urder side (fig. $2 b$.)

I am also indebted to H. G. Harrington Esq., for this species. 
FIGURE 3.

PHASMA (EURYCANTHA ?) GRACIOSA. Westw.

\footnotetext{
I'hasma eapitc spinis coronato, metnsterno dilatato, abdominis lateribns lobis spinosis armatis, tegminibus alarum longitudine $\frac{2}{3}$ aequantibus fuseo flavoque variis, alis abdominis longitndine pallide roseis, costa fuscescenti, venis omuibus fusco-nelulosis.

Phasma having the head enical above, erowned with strong spines; the metastemum dilated and spined ; the sides of the aldomen with spinose membranes; the tegmina $\frac{2}{3}$ of the length of the wings, varied with brown and yellow : the wings as long as the abdomen, pale rosy with the costa lorownish, and all the reins clouded with brown.

Length of the body $3 \frac{3}{4}$ inches. Expausion of the wings 6 inches.

Inlabits Prince of W'ales's Island. In the Collection of the Rer. F. W. Hope.
}

Description.-This insect here represented is evidently a male, notwithstanding the great derelopment of the boat-like termination of the rentral surfaee of the abdomen (fig. $3 \mathrm{c}$ ). The erown of the head is armed with a eirele of six spines (in pairs, fig. 3 b), and with three smaller ones on each side. The antenure have the tips broken off in the only specimen I have seen. The sides of the thorax are spined, with its two anterior divisions of nearly equal length, the metanotum being divided into two portions, each equal to the pronotum in length; the metasternum is greatly dilated, flattened, and spined beneath (fig. $3 a$ ). There are two erect spines between the base of the fore wings, and another at the base of each; the lcgs are angulated, and rery much spined, especially the posterior tiljic.

OBservations. - In our present ignoranee of the female of this fine insect, I am nuable to determine whether it ought to be formed into a separate subgenus, or whether it be not the male of a speeies of Eurycantha. The speeimen before us is remarkable for the size of the fore wings which (exeept in Prisopus) are never more than half, and often not $\frac{1}{10}$ of the length of the wings, in the speeies of Pbasmidie. The insect thus appears to be intermediate between Prisopus and Euryeantha, agreeing with the latter in the armature of the legs and dilated metasternum.

This is one of the fine iuscets sent to the Rev. F. W. Hope by that very zealous Naturalist, Dr. Theodore Cantor. Others equally worthy of being figured, are reserved for publieation in this work. 


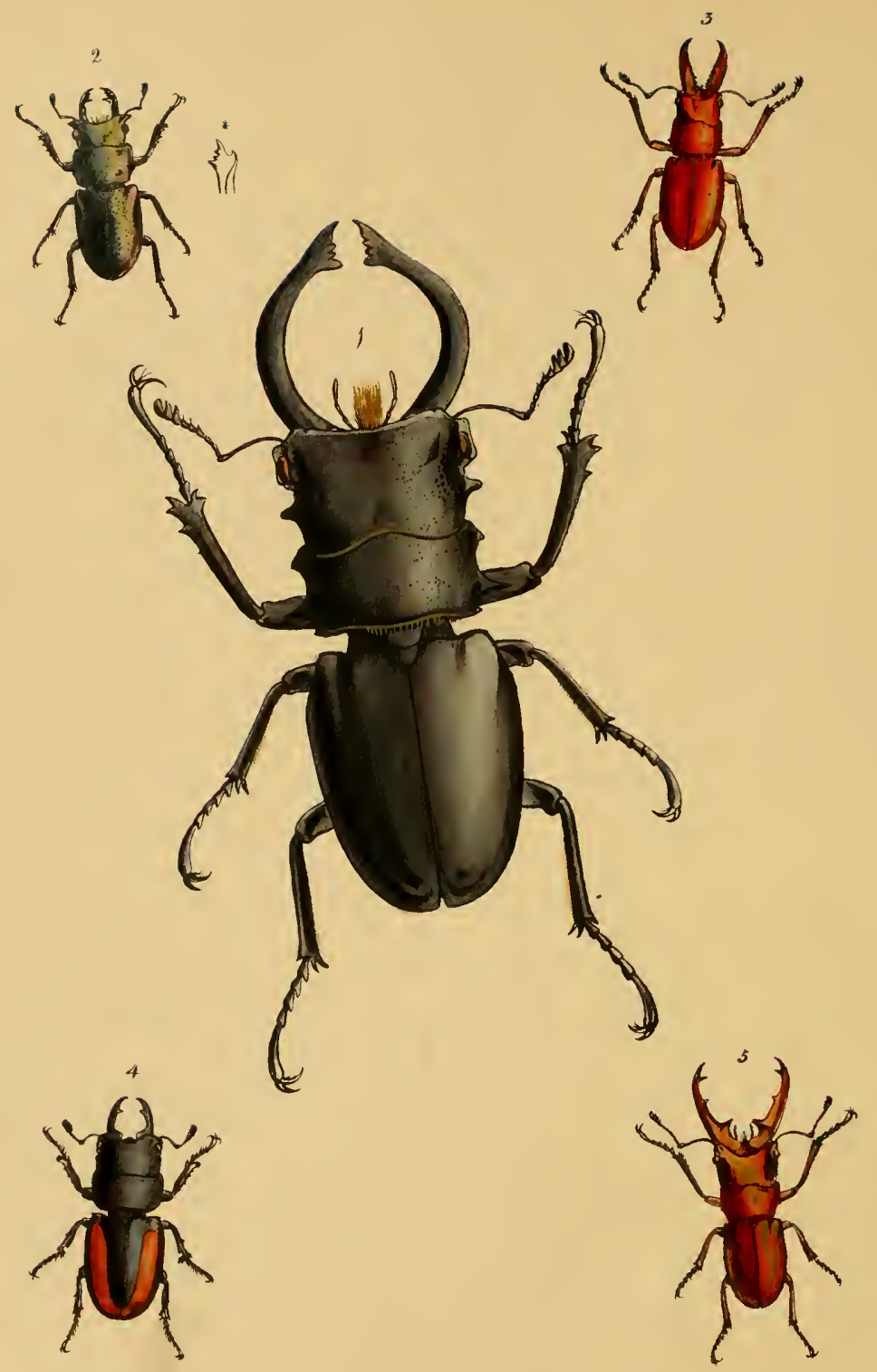





$$
\text { - }
$$


LUCANUS DUX. Westw. (Axishs of Nat. Hist., Octouen 1841.)

Lueanus ater; clytris nitilis; capite plano utrinque rugoso punetato, unargine antieo elevato; lateribus pouc oculos utrinque spina obtusa arnatis ; mandibulis longitudine eapiti et prothoraci sequalibus, valde curvatis ; intus (dentibus tribus subapiealibus execptis) inermilus; pronoto tenuissime punctato, utriuspue bispinoso, angulisque posticis acutis, tibiis anticis apice externo 3 -ckentntis ; posticis 4 inernilns apicibus externis acutis.

Lucanus black, with the elytra glossy ; the heal flat and on each side rugose and strongly punetured, the anteri or margin elevatel and the sides behind the eyes armed with a strong obtuse spine; the mandibles as long as the head and prothornx, strongly curved; the inside destitute of teeth exeept three small ones near the tip ; the pronotum is delieately punctured, armed with two spines on each side, and with the posterior angles acute, the fore-tibia laving the onter apex 3-deutate, and the four posterior tibiæe not spined on the outside but terminating exterually in a sharp point ; (male.) Length of the inseet, ineluding the mandihles, $4 \frac{1}{8}$ inches.

Inhabits Manilla. (D. Cuming.) la the Collection of the British Mluseuur.

Descriptios.-The head is very delieately punctured all over the upper surface; the middle of the dise of the prothorax is howerer nearly smooth; the front of the head is excavated as in some allied species, having the front margin elevated, prominent, and nearly straight. Near the anterior lateral angles of the head is a slightly elevated angular mark; and near the base of cach of the larger spines of the prothorax is an impressed dot. The cyes are entircly intersected by the flat septum; the four posterior tibire have a slculer line of fulrous pile on the iuside; and in the unique specimen in the British Museum the left fore tibia has a minute spine behind the subapical teeth.

Observations. - This insect is rery closcly allied to $L$. Alces, but that species has a strong tooth at the base of the mandibles on the inside. Dr. Burmeister has, indeed, appended a note to the specimen of the British Museum Collection affirming it to be a varicty of that species. I am well aware of the very variable size of the teeth of the mandibles in the Lucani, which has induced this opinion; but as it appears to me to be a fixed principle that gigantic male specimens of any of the cornuted insects should have the horns and teeth developed to excess, I can scarcely think that the inseet before us ought to be referred to a species, the ordinarily smaller males of which are more strongly armed witl teeth than the specimen here figured.

\title{
FIGURE 2.
}

\section{licands Platycephalus. Hope. (Axwals Nat. Hist. xii. 364.)}

\begin{abstract}
Lucanus niger subreneus, nitidissinus tenuissime punctatus; mandibulis eapite vix longioribus, apicibus acute digitato-furcatis; eapite antice lato plano, ante oeulos utrinque angulato porrecto; thorace transverso-quadrato, utrinque prope angnlum lateralen subfossulato ; clytris fere glabris, corpore infra eoneolori ; tibiis antieis serratodentatis, postieis 4 in medio inermibus apicibus spirosis; tarsis posticis subtus luteo-setosis, oculis integris rotundatis.

Lueauus lrassy black, very glossy, and very debeately punctured; the mandibles scarcely longer than the head, with the tips acutely digitate-furcate (fig. 2*); the head broad and flat in front, with the antcrior lateral angles acutely porreeted in front of the eyes; the prothorax transverse-quadrate eonvex, with a small gutter near the lateral angles, beyond the middle of the sides; the elytra nearly smooth, the body beneath concolnons ; the fore-tibire serrato-deutate, the four hind ones unarmed on the outside, with the tips spined; the tarsi are furnished beneath with a luteous enshion, and the eyes are entire and rounded; (male.) Length, inelnding the mandilles, $8 \frac{1}{2}$ to 12 lines.

Inlıabits the liasyah hills and Assam. In the Collectiou of the Rev. F. W. Hope.
\end{abstract}

ObSERVATion.-This curious species, in its sectional character, comes near to L. metallifer Boisdural (Vor. de l'Astrolabe); but its short palmated mandibles and transversely oblong-quadrate mentum, denticulate fore tarsi, glossy body, \&c., at once distinguish it.

\section{FIGURE 3.}

\section{LUCANUS MULTIDENTATUS. WEST.}

Lueanus eastaneus, aneo vix tinetus subnitidus; sub lente misutissime pusetatus; capite subquadrato antice emarginato rertice plano, mandibulis capite parum longioribus depressis, apiee acutis et subeurvatis, intus multidentieulatis, antennis longis nigris; oculis integris rotundatis, mento subtriangulare, prothorace pone medium lateribus angulatis, tibïs omnibus angustis extus inermibus apice externo acuto. 
Lucanus chestnut-coloured, very shghtly tinged with brassy, rather glossy, and seen under a lens very delieately punctured, especially on the pronotum; the head subquadrate, emarginate, depressed in front ; the crown of the head smooth, and the sides not spined; the mandibles rather longer than the head, flattened above, with the tips acute and incurved, the inner edge with about I2 minute teeth; the antennze long and black, the eyes entire and rounded, and the mentum sub-triangular; the protborax has the sides beyond the middle angulated; all the tibix are narrow, without any teeth on the outer margin, and with outer tip acute; (male). Length, including the mandibles, 11 inch.

Inhabits the East Indies. (Dr. MacClelland.) In the Cabinet of the Entomological Society.

OBservatrons.-This species, at first sight, nearly approaches L. Astacoides Hope (Linn. Trans. xviii. 590), MacClellandi Hope (Annals N. Hist., xii. 366,) \&c. But in the entire eycs, slender simple tibiæ in the males, \&c., it comes much nearer to L. metallifer and platycephalus. The only specimen I have hithcrto seen is in the collection of the Entomological Socicty; liberally presented, with numerous other Indian insects, by Mr. MacClelland, the talented editor of the Calcutta Journal of Natural History.

FIGURE 4.

LUCANUS INQUINATUS. WEsTW.

Lucanus niger nitidus, capite transverso quadrato, antice subemarginato, lateribus punctatis et pone oculos subangulatis; mandibulis (maris) eapitis longitudine, gracilibus basi intus dilatatis denteque pone medium armatis, antennis brevioribus, oculis septo suldivisis, protborace transverso latcribus punctatis angulis posticis rotundatis, elytrorum singulo plaga magna sublaterali sanguineo-fulva inquinato.

Lucanus black and glossy, with the head transverse-quadrate, sulsemarginate in front, the sides punctured and beyond the eyes slightly augularly incised ; the mandilles (of the male) as long as the head, slender, dilnted at the base within, and with a small tooth beyond the middle; the antenna short, and the eyes subdivided by the septum; the prothorax transverse convex, with the sides punctured and the hind angles rounded off ; each elytron lias a large broad bloody orange-coloured streak, extending near the sides to the tips. Length of the male, including the mandibles, $1 \frac{1}{3}$ inch.

Inhabits India. Col. Whithill. In the Collection of the British Museum.

Description.-The male has the fore tibire externally scrrated with minute obtuse teeth, and with four rather more conspicnous ones, the apex prodnced and bifid; the middle tibire with a very minute spine on the middle of the outer edge; and the apex outwardly bidentate; the inner edge near the tip has a strong semicircular incision, beyond which it is slightly dilated and spiued, and the hind tibiæ in this sex are unarmed on the outer edge *; the tip outwardly acute, and the imner edge at the tip dilated and bidentate. The female has similar fore tibix, except that the tip of the outer edge is dilated or subpalmate, with three or four small obtuse teeth; and each of the four posterior tibire has a small spine in the middle of its outer edges. The female has the head and mandibles small and very much punctured.

\section{FIGURE 5.}

LUCANUS STRIGICEPS. WESTW.

Lucanus castaneus, æneo-tinctus nitidus ; capite magno, quadrato, antice cmarginato depresso vertice suluplano, lateribus pone oculos strigosis, mandibulis eapite dimidio longioribus, intus versus basin dente lato irregulari, abo minuto medio, tertioque majori acnto ante apicem, antennis longis nigris, oculis globosis septo parum incisis, mento subtriangulari prothoracis lateribus pone medium angulato-truncatis; tibiis omnibus margine externo inermibus, apicibus acutis, intus cum tarsis subtus fnlvo-setosis.

Lucanus chestnut-colonred, with a brassy tinge and glossy ; the head large and quadrate, emarginato-depressed in front ; the crown of the head flattened, the sides behind the eyes with several impressed streaks; the mandibles half as long again as the head, armed near the base within with a large irregular tooth, another small one near the middle and a third larger and acute towards the tip ; the antenna long, black, and slender; the eyes globose, but slightly incised by the septum ; the mentum subtriangular; the prothorax with the sides straight, but beyond the middle obliquely angulated; all the tibix have the outer edge destitute of spines, the apex acute ; their inner edge, as well as the under side of the tarsi, clothed with short fulvous hairs; (male). Length, including the mandibles, nearly $1 \frac{1}{2}$ inch.

Inhabits the Himalayas. In the Collection of A. Melly, Esq., and my own.

Observations.- I am indebted to H. G. Harrington, Esq., for my specimen of this pretty species, which differs from every known insect in the family by the series of deeply impressed lines behind the eyes. It approaches L. metallifer in several of its other characters, such as the long legs and antennæ, the large head and mandibles, and metallic colouring.

* By a mistake, the hind tibiæ of the male in some impressions of the plates are represented as armed with a minute spine. 



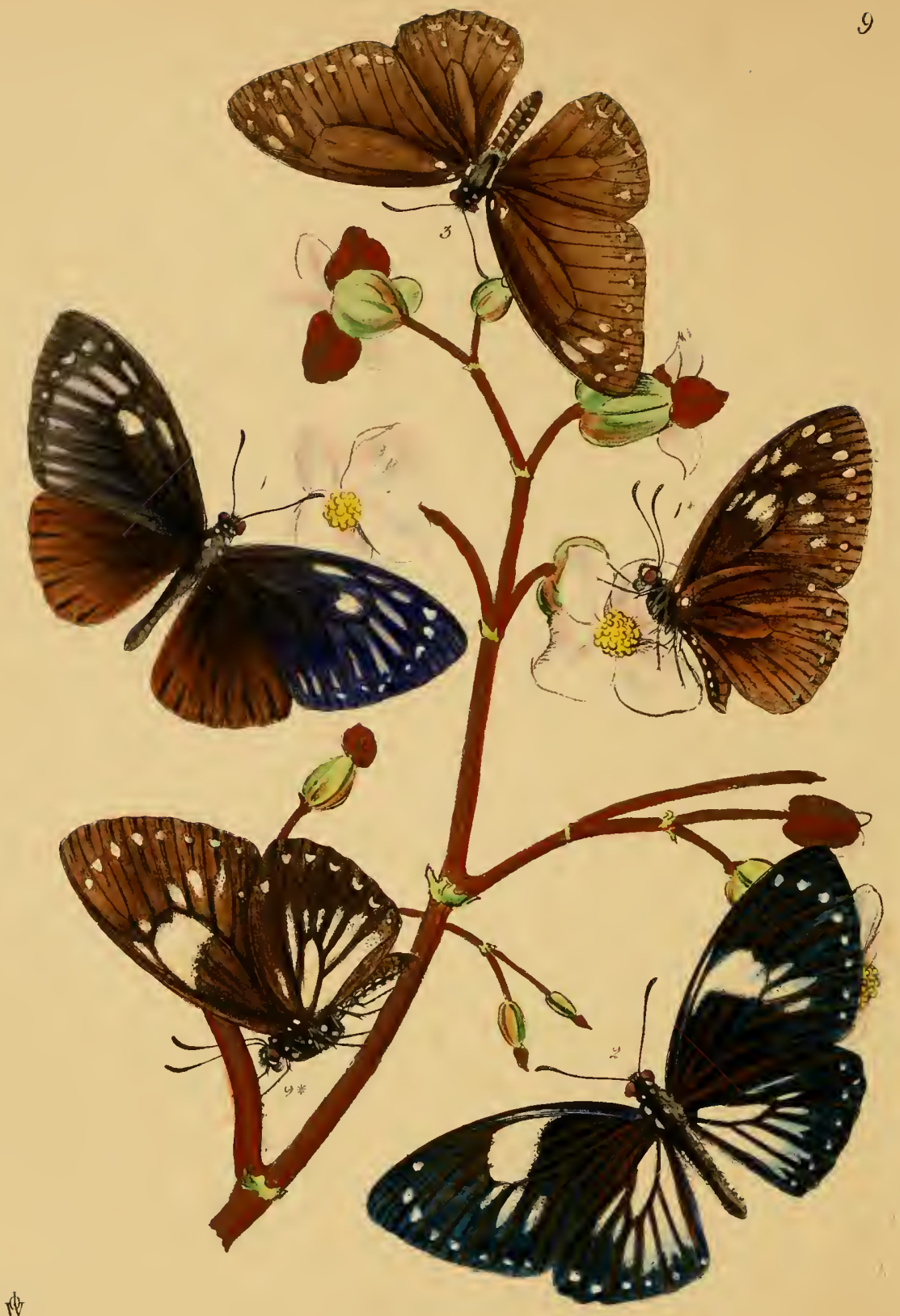

13.47 . 



\title{
PLATE IX.
}

\section{(ORDER-Lepidoptera. Section-Diursa. Famliy-Papluionide, Lfacil.)}

A rery slight acquaintance with any extensive tribe of animals discorers to the mind of the observer that, notwithstanding the isolation of species in nature, cach individual in fact working for its own individual ends, (execpt in the case of social species, where the members of one species work together in the service of the community, there exists a certain degrec of relationship amongst various species founded on their greater or less structurnl resemblance. Thus it is, that, without in the slightest manner interfering with each other's habits, and not having the slightest connexion with each other in respect to the ordinary objects of their existence, we admit a relationship between two specics of butterflics, and affirm that they are more nearly related to each other than a butterfly and a moth; and thus it is that we form a number of species, posscssing certain characters in common, into orders, families, genera, \&c., cstablished in all cises upon this kind of relationship, which is termed the affinity of different specics. Another kind of relationship, however, occasionally presents itself to our notice, possessing great interest, aud founded on the more partial resemblance of a species of one group with those of another, which is termed the analogy of species. Thus, whilst the bat belongs to the Mammalia it has an aualogy with the birds in its flying habits; and thus Morpho Camadera, (ante, plate 4,) in its cye-like markings, resembles a pavonine bird. The insects on the accompanying plate present to us another variety of this aualogical kind of relationship. In the structure of all those organs which have beeu selected for the characters of the genera of the Diurnal Lepidoptera, they belong to the gemus Papilio; but in the form and colouring of their wings they so closcly resemble some of the spccies of the genus Euploe, in a diffcrent family, that without careful cxamination they would be arrauged amongst the latter.*

\section{FIGURE 1. \& 1*. PAPILIO PARADOXUS.}

(Zelima Paradoxa, Zinken in Nov. Acta. Vol. XV. p. 162, pl. 1.5, f. 9-10.)

\begin{abstract}
Papilio alis integerrimis, anticis oblongis, atro-creruleis fulgidissimis, fascia e strigis cyaneo-albieantibus parique maeularum antieo serieque punetorum postica albis; postieis purpurascenti-nigris punetis marginalibus obsoletis ereruleis.

Papilio with the wings very entire, the fore ones oblong and rounded on the outer margin, of a black-blue colour and very glossy, with two or three white spots at the eud of the discoidal cell, followed by a row of bluish white streaks, and a submarginal row of small white spots; the hind wings purplish-black, with an obsolete row of blue spots. Expansion of the fore-wings, $3 \frac{1}{2}$ iuelies.

Inhabits Java. In the Collection of the British Museum.
\end{abstract}

Descriptiox.-The only specimen I have seen belonging to this species is a male in the Collection of the British Museum; the face, neck, and thorax are spotted with white, as are also the sides of the breast and abdomen: this specimen exhibits no trace (on the upper side) of the sub-marginal spots of the hind wings, which indeed Zinken describes as "obsoletis ;" the four wings at the base bencath bear a small white dot, and the row of oblong streaks is reduced to oval spots, one of the series heing ranting; the last branch of the sub-costal vein arises at a short distance beyond the origin of the preceding branch. The general appearance of the insect is that of Euploca Hidamus.

- The investigation of these different kinds of relationships has, during the present century, attracted mueh attention, espeeially from the writings of Messrs. MacLeay, Vigors, and Swainson. I may also refer to a paper by myself in the 18 th Volume of the "Linnean Transactions." 
Papilio alis integerrimis, anticis fusco-nigris cyaneo colore pone medium parum tinetis, macula magna ad apicem arca discoidalis, strigisque tribus parvis approximatis, serieque submarginali punctorum alborum ; posticis nigrofuscis cyaueo tinctis, area discoidali alba strigisque elongatis radiantibus cyaneo albicantibus, serieque submarginale punctorum alborum ; alis subtus fuscis maculis ut in pagina superiori dispositis.

Papilio with the wings very entire, the fore ones of a black-brown colour slightly glossed beyond the middle with a purple cyaneous tinge, with a large white spot at the extremity of the discoidal cell, below whieh are three short bluish-white streaks, the middle one longest, and a submarginal row of small white spots ; the lind wings are of the same colour as the fore ones, with the discoidal cell white, followed by a series of long bluish-white streaks, (the space between the anal and discoidal veins having the white most extended,) also with a submarginal row of white dots ; wings beneath fulvous brown, with white spots arranged as on the upper side ; (male.)

Expansion of the fore wings nearly 4 inches.

Inhahits Java (?) In the Collection of H. G. Harrington, Esq.

Observations. - The only specimen I have seen of this supposed species is contained in Mr. Harrington's Collection, received from Dr. Becker as the female of the preceding insect. The specimen, hotrerer, is a male, and in general character, form of the wings, and arrangement of the veius, approaches closely to P. paradoxus. It is, however, far from being so brilliantly glossed with blue as in that species, and the distribution of the pale colour of the wings is different; the maximum of pale coloration being within the discoidal cell, whereas in the foregoing species it is beyond it. There is, howerer, so much rariation in these spotted insects, that I should not be surprised to find it ultimately resolved into a variety of $P$. paradoxus.

\section{FIGURE 3.}

papilio astina. Horsfield MSS.

Papilio alis anticis oblonge-dilatatis, margine externo parum emarginato, area discoidali valde elongata ; omnibus lutea-fuscis ; anticis maculis duabus ovalilous pone medium serieque submarginali punetorum alborum, postieis parvis, integris serie submarginali lunularum albarum ; alis subtus similiter coloratis.

Papilio with the fore wings oblongo-dilated, with the outer margin slightly emarginate in the middle, and the discoidal cell (in all the wings) very much elongated; all the wings luteous-brown, the fore wings with two oval white spots beyond the middle, and a submarginal row of white spots, which are continued on the hind wings in the shape of lunules. The hind wings are small and entire; all the wings beneath are similarly coloured and marked; (female). Expansion of the fore wings, $3 \frac{1}{4}$ inches.

Inhabits Java. (Dr. Horsfield.) Iu the Collection of the East India Company.

Onservatioss.-This insect was at first regarded as the female of P. paradoxus, but having been favoured by Dr. Horsfield with an opportunity of comparing his unique specimen with the male of that species in the British Museum, several distinguishing characters are found to exist, which seem sufficient to disprove such an opinion; snch, for instance, as the great length of the discoidal cell, the emission of the last branch of the sub-costal rein half-way from the extremity of the discoidal cell and especially the subemarginate form of the fore wings, whereas in the two males above described they have the outer margin rounded.* Hence Dr. Horsfield has proposed the name of Papilio (Zelima) Astina for this insect, which I hare great pleasure in adopting.

Papilio Lacedemon (Fabricius Ent. Syst. iii. 1, p. 36 ; Donoran, Ins. Ind. pl. 17, fig. 3. Edit. Westw.) is nearly allied to this insect (as suggested to me by Mr. Edward Doubleday). Haring compared Donoran's figure with Jones's original drawing, I am able to state that that species has a marginal row of triangular spots on the fore wings, in addition to the sub-marginal patches, and a submarginal row of black lumules on the hind wings beneath, varied with whitish and pale-greenish scales.

I have not adopted the genus Zelima, as it presents no characters to distiuguish it from Papilio.

The plant represented in the plate is the Begonia albo-coccinea.

\footnotetext{
* In various other species it is the males which have the wings emarginate, whilst they are rounded in the females.
} 

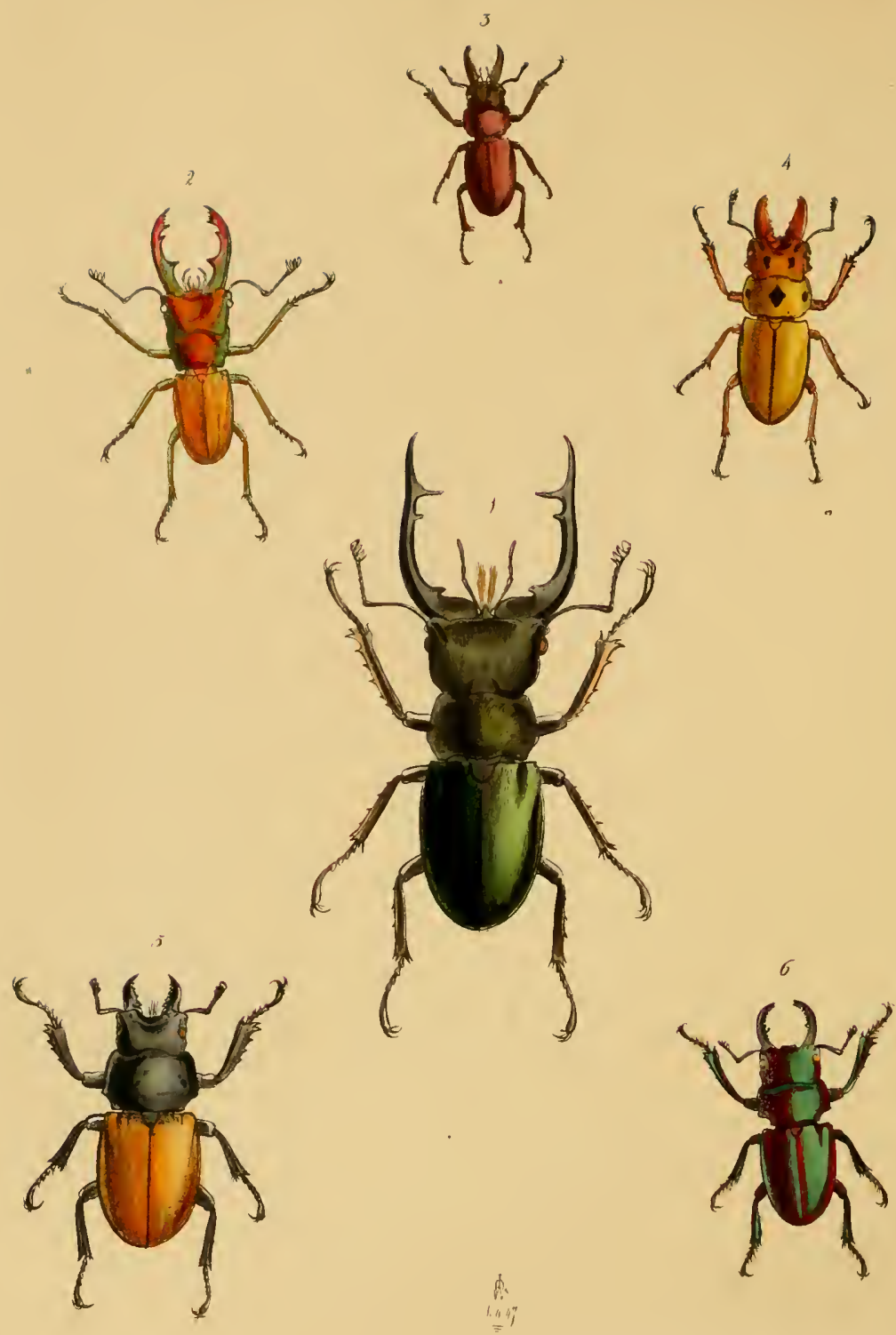




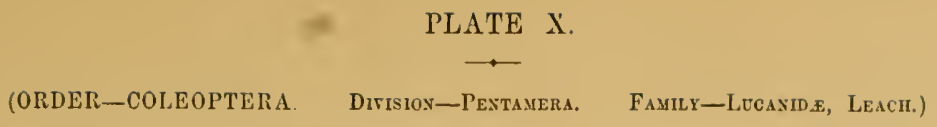

Figure 1. LUCanUs MEaresil. Ilope. (Axis. Nat. Hist. xii. 364. Cat. Lucas, p. 10.)

Lueanus aneo-niger, serieie luteseenti indutus, mandibulis valde exsertis, gracilioribus et longieribus quam in $\mathrm{L}$. Cervo, versus basin iutus dente obtuse subreflexo, prope medium altero armatis, apieibusque late furcatis; clytris nigro-seneis nitidis et subtilissime punetulatis; tibiis rubro-piccis; elypeo cenieo deflexe integro, frente valde reflexo, capitis lateribus valle elevatis, angulis posticis rotundatis. Variat mas mandibulis inter basin plus minusve denticulatis.

Lueanus brassy-black, elotlied with a fine dirty buff pubescence, the mandibles very porreeted and deflexed heyond the mildle, lenger and mere slender than in L. Cervus; armed near the base within with a small subreflexed obtuse teoth, and with another near the middle; the tips strongly fureate; the elytra are very glossy and delieately punetured; the tibite dark pitchy red; the clypeus conieal, deflexed, and enture; the front of the head much reflexed; its sides mueh elevated, with the linder angles of the elevated part rounded. The male varies in linving the mandibles more or less dentieulated between the base and the middle.

Length of the insect, including the mandibles, 28 lines.

Inhabits Sylliet. In the Colleetions of the Rev. F. W. Hope, and A. Melly, Esq.

Observation.-This finc speeies belongs to the same group as L. Cernus. It is nearly allied to L. Lunifer, Hope in Royle's Himalaya, but is more elcgant in its proportions.

FIGURE 2. LUCANUS RANGIFER. Scuönnerr. (Sry. Ins. i. pt. 3, p. 322.)

(Varietr. L. De Haani, Westw. Anx. Nat. Hist., October 1841.)

Lueanus æene-rufescens, serieie albida plus minusve indutus, elytris pedibusque fulvescentibus; capite maxime antice latieri ; oeulis vex septatis ; mandibulis longis, dente uno ante alteroque pone medium, denticulis parvis subapicalibus intus armatis; antennis valde elongatis, clava 4-phylla, 1 mo articulo clavæ maximo ; pronoto postice angustiori ; pedibus longis, tibiis antieis in medio (interdum) spina minuta armatis ; 4-pestieis inermibus.

Lucanus of a reddish eolour with a brassy tinge, more or less clethed with pale pubescence; the elytra and legs fulvous, the head rery large and broadest in frent, the eyes scarcely eut by the septum, the mandibles long, with one teoth before and another beyond the middle, the apex with sereral minute teeth; the antennw very mueh elongated, with a 4 -jointed elub ; the first jeint of the elub being largest ; the pronotum is narrowed behind ; the legs are long, with the fore tibire sometimes armed in the middle with a very small spine; the four hind tibiæ unarmed. Length of the speeimen figured, ineluding the mandibles, 19 lines.

Srx.-Lueanus Tarandus Thunberg, Moseew. Trans, 1811, tab. 12, fig. 1 ; nec. L. Tarandus Swederus, Stoekh. Trans. 1787, tab. 8, fig. 1. L. metallifer, Boisduval Entomel. Astrolabe. Coleopt. pl. 6, fig. 20.

Inhabits Borneo. In the Collections of the Rev. F. W. Hepe, A. Melly, Esq., and the British Museum.

OBSERYATION.-This curious species forms a very distinet subsection in the genus Lucanus, distinguished by its large head and long mandibles, antennæ, and feet, its somewhat semi-circular lower lip, and metallic colouring, \&c. It appears to vary considerably in the toothing of the mandibles, a large specimen in the British Museum (var. L. macrognathus, White MS.) haring a number of minute teeth between the base and the first large tooth, and as many as 16 minute subapical denticulations; its fore tibire are also unarmed, the head and mandibles bronzed, and the sides of the head strongly punctured. It was collected by Hugh Lowe, jun., Esq., in Borneo.

FIGURE 3. LUCANUS JENKINSII. WESTW.

Lueanus eastaneus, eapite mandibulis pedibus et sutura elytrorum nigris, eapite antice deflexo punctato, tuberculis duebus parvis in medio fere obseletis, mandibulis capite longioribus, graeilibus intus denticulatis, oculis dimidiatim septatis, tibiis antieis extus serratus, intermediis spina minuta mediana, postieis extus inermibus, intus ad apieem faseieulatis, elytris sub lente tenuissime punctatis, mento subsemieireulari.

Lucanus of a dark ehestnut coleur, moderately glessy, with the head, mandibles, legs, and suture of the elytra black, the front of the head deflexed and punetured, with an impression on the erewn of the head, eaused by two small raised tubereles; the mandibles rather longer than the head, slender and denticulated within, the eyes half divided by the septum (extending obliquely to the base of the mandibles), the fore tibiæe outwardly dentieulated, the middle ones with a very small spine in the middle, the posterior ones outwardly unarmed, but furnished with a small 
tuft of fulvous hairs at the tip within ; the elytra, under a lens, are very delicately punctured, and the mentum is sornewhat semicircular. Length of the insect, inclnding the mandibles, very nearly $l$ inch.

Observation.-This species belongs to the section containing Luc. omissus, Hope, foreatus H., Astacoides H., \&c.; and comes nearest to L. Mac Clellandi H. (Ann. Nat. Hist., xii. 364, and Cat. Lucan, p. 13), from which I find it, however, distinct. It is named in honour of Major F. Jenkins, by whom it and numerous other fine and new species have been kindly communicated from Assam.

FigURE 4. LUCANUS OCCIPITALIS. Hope. (Cat. Lucan, Coleopt. p. 13.)

Lucanus luteo-fulvus, capite maguo, pone oculos acute angulato margine antico valde excavato, utrinque nigro binaculato, occipite carinis duahus brevilons curvatis nigris, mandibulis magnitndine variis, oculis dimidiatim septatis ; prothorace capite angustiori margine tenui, macula disci angulata, alterisqne duabus versus angulos posticos nigzis, corpore subtus pedibusque luteo-castaneis, tibiis linea supra nigra; anticis extus subserrulatis, 4 posticis in $\delta$ inermibus (vel interdum intermediis spina minima mediana); in + singula spina minuta media armata. Fæmina capite mediocri mandibulis, marginibus et maculis prothoracis suturaque elytrorum nigris.

Lncanus orange-clay coloured; with the head large, having an angulated tubercle on each side behind the eyes (which are half-divided by the septnm), the front margin of the head very much excavated, with two black spots near the base of the mandibles, and two angulated slightly raised black carinæ on the crown ; the mandibles varying in form, prothorax narrower than the head with a slender margin, and a black diamond spot in the middle and two small ones at the sides; body beneath, aud legs, chestnut clay-colour, the tibiæ with a black line, the fore ones subserrated, the four hind ones in the male unarmed (or the middle ones with a very minute spine); in the female each with a small spine in the middle. The female has a moderate-sized head, with short mandibles, which, as well as the margins and spots of the prouotum, and the suture of the elytra, are black.

Length of the insect, including the mandibles, from $10 \frac{1}{2}$ to 17 lines.

Inhabits the Phillippine Islands (Cuming). In the Collections of the British Museum, Entomological Society, Hope, \&c.

Observation.-This species, with several others from the Eastern Islands and from western tropical Africa, form a distinct section, which Mr. Hope has named Prosopocoilus. There is much difference in the form of the mandibles of the male in the species before us: the largest specimen I have seen, in the British Museum, has them nearly $\frac{2}{3}$ of an inch long, with a strong tooth before, another compound owe beyond the middle, and a bifid apex; another, in Mr. Hope's Collection, has them rather shorter than the head, with a small tooth near the base, another before the middle, and three small subapical ones, whilst in the specimen figured they are short and internally, irregularly, and obtusely subserrated.

\section{figure 5. leCaNus castanopterus Hope. (Zool. Misc. i. 22, and Cat. Lucan, p. 18.)}

Lucanus latus lavis niger; mandibulis maris porrectis capitis longitudine arcuatis et denticulatis, capite ad angulos anticos subquadrato, oculis omnino bipartitis, clypeo maris emarginato, prothoracis angulis posticis oblique subtruncatis; elytris castaneo-fulvis, basi extremo et scutello nigris; tibiis anticis latis denticulatis, posticis 4-inermibus.

Lucanus broad, smooth, and black; the mandibles of the males porrected, as long as the head; curved at the tip and denticulated; the head having the anterior angles subquadrate, the eyes entirely divided by the septum; the elypeus of the male emarginate; the posterior angles of the prothorax obliquely subtruncate, the elytra chestnutfulvous with the base and seutellum black, the fore tibiæ broad and denticulated, the four hind ones unarmed.

Length of the male, including the mandibles, 17 lines; of the female, 12 lines.

Inlabits Nepaul. In the Collections of the British Museum, Entomological Society, Rev. F. W. Hope, \&ic.

\section{FIGURE 6. LUCANUS ERATUS. Hope. (Zool. Trans. i. 99, pl. 14, fig. 2. 9 )}

L. æneo-virens, cupreo-nitens; capite et pronoto tenuissime granulosis, maudibulis maris longitndine capitis falcatis intns pone medium deuticulatis ; capite quadrato, antice emarginato, antennis nigris ; prothoracis angulis posticis enarginatis; corpore infra cupreo brunneo, clypeo transverso porrecto, oculis omnino bipartitis ; mento semicirculari valde piloso ; tibiis anticis latis extus denticulis circiter 5, 4-posticis in utroque sexu simplicibus.

Lucanus brassy-green, glossed with copper; the head and pronotum very delicately grannlose, the mandibles of the male as long as the head, falcate, and armed beyond the middle with about 9 small truncate teeth, the head quadrate, and marginate in front, the antennæ black, the hind angles of the prothorax emargiuate; body beneath copper-brown, the clypeus transverse and porrected; the eyes entirely bipartite, the mentum semicircular, and very pilose, the fore tibiæ broad, with about 5 small teeth, the four posterior ones simple in both sexes.

Length of the insect, including the mandibles, $10-15$ lines.

Inhabits the Tennasserim Coast, and Prince of Wales' Island. In Coll. British Museum, and Hope. 

11.

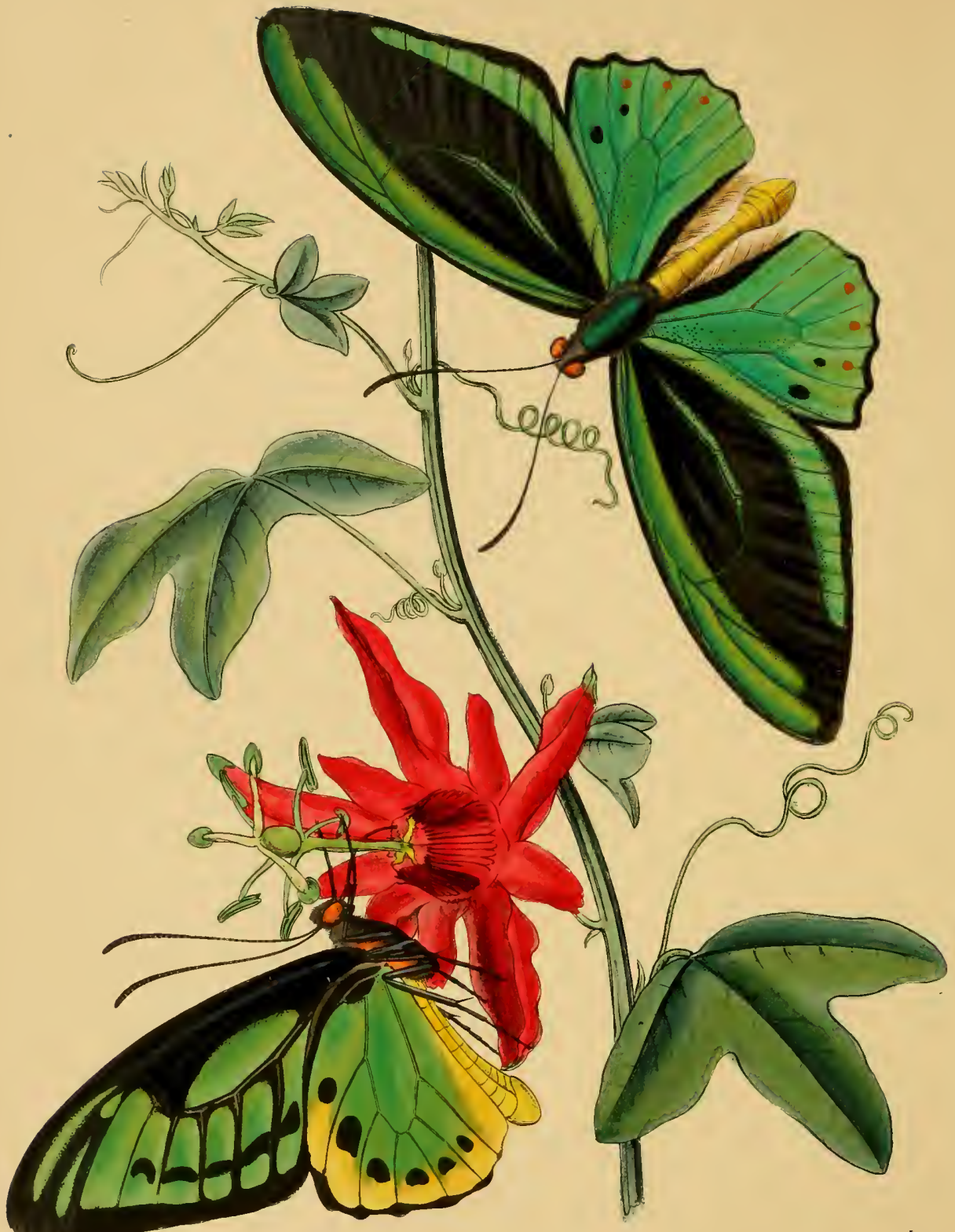





\section{PLATE XI.}

\section{(ORDER-Lepidoptera. Section-Diersa. Family-Papilionide, Leach.)}

ORNithopterus poseidon. E. Doubleday. (An. Nat. Hist. xix. 173. March 1847.)

\footnotetext{
Ornithopterus alis holoserieco-viridibus limbo nigro, anticis fascia longitudinali latissima nigra venis viridibus divisa ; posticis subtus aureo-viridibus nigro-maculatis angulo ani aureo.

Ornithopterus with the wings satiny-green, with a narrow black border, the fore ones with a very broad longitudinal fascia divided by green veins; hind wings beneath golden green with black spots, and the anal angle shaded to golden colour.

Expansion of the fore wings, $6 \frac{1}{2}$ inches.

Inhnlits Darnley Island. In the British Museum.
}

Descriptios.-Ahore, anterior wings with the entire limb deep velvety black, the dise occupied by a broad fascia of the same colour, united to the black margin below the apex, divided by the median rein, and branches which are golden green; its inner side more fuscous and opaque. The space between this and the costal and inner margins is occupied by two stripes of bright golden-or satiny-green, shading to bright coppery. The anterior of these is narrow at the base and becomes gradnally wider uutil near the apex of the wing, when it suddenly narrows. The lower follows a direction parallel to the inuer margin until near the anal angle, gradually widening to this point, when it is bent abruptly uprards, and extends parallel to the outer margin more than half its length. Hind wings small, subtriangular, the anterior and outer margins rounded; satiny green with coppery reflections, the limb narrowly black, the outer margin with one or more round black dots; and generally near the outer margin is a series of round orange spots between the veins; anal margin black, deeply fringed with orange hairs.

Below, the fore wings have the limb black, broadest on the costa toward the apex, bearing a green spot and two green streaks; the disc green, divided by black veins, and bearing a subcontinuous row of five black spots between the middle and outer margin. Hind wings golden green, the golden colour predominating externally, the anterior and outer margins black, with a row of six black spots beyond the middle of the wing, the costal spots sometimes preceded by an orange dash; the anal angle broadly golden yellow. Head aud thorax black, the latter with a long golden green vitta abore, and a blood-coloured patch on each side beneath the base of the wings. Abdomen golden yellow. (Male.)

Observations. - This beautiful butterfly is stated by Mr. E. Doubleday, in his Genera of Diurnal Lepidoptera, to have been found abundantly by Messrs. Jukes and Mac Gillivray flying, very high on Darnley Island, among the cocoa-nut groves. The natives of that little remote rocky islet capture them, and securing them by one end of a long thread, they fasten the other end of the thread to their hair, allowing the butterflies to flutter aruund their heads.

As the question may be raised whether $O$. Poseidon is not a geographical variety of $O$. Priamus, it is necessary to state its differences from that and the supposed species allied thereto. From the male of O. Priamus it varies, as suggested by Mr. Doubleday, in the form of the green bands of the fore 
wings, and in the green irroration of the median vein and its branches at the base, its much smaller hind wings, less broadly bordered with black, in the golden green hue of its posterior wings below, and especially in the large golden orange patch at the anal angle, (which is black in O. Priamus, ) and the suffusion of the same colour aloug the outer margin. A variety of $O$. Priamus, which seems to approach O. Poseidon very closely, is described by Dr. De-Haan in his fine work on the insects of the Dutch settlements from New Guinea; another variety is figured in Freycinet's Voyage, p. 183, f. 3. Orn. Urvillianus Guér. (Entom. de la Coquille, Ins. pl. 13, figs. 1, 2) rery nearly resembles O. Priamus, but has the green colour of the wings replaced by a brilliant violet blue, with a large hispid patch between the middle and the anal angle; the disc of the hind wings above is black, witl the veins broadly blue, dilated into an irregular submarginal fascia of the same colour; the under-side more nearly resembles $\mathrm{O}$. Poseidon, the green of the fore wings being howerer replaced by blue; whilst the hind wings are golden yellow with green reflections and with a black spot near the anal angle, forming the innermost of a row of seven spots.

O. Tithonus, figured by De-Haan, Tab. 1. fig. 1, is a noble species allied to O. Priamus, but having a broad green bar along the middle of the fore wings, and the hind wings very narrow, with a broad black anal margin.

The beautiful plant represented in the plate is the Disemma aurantia, a native of New Caledonia. 


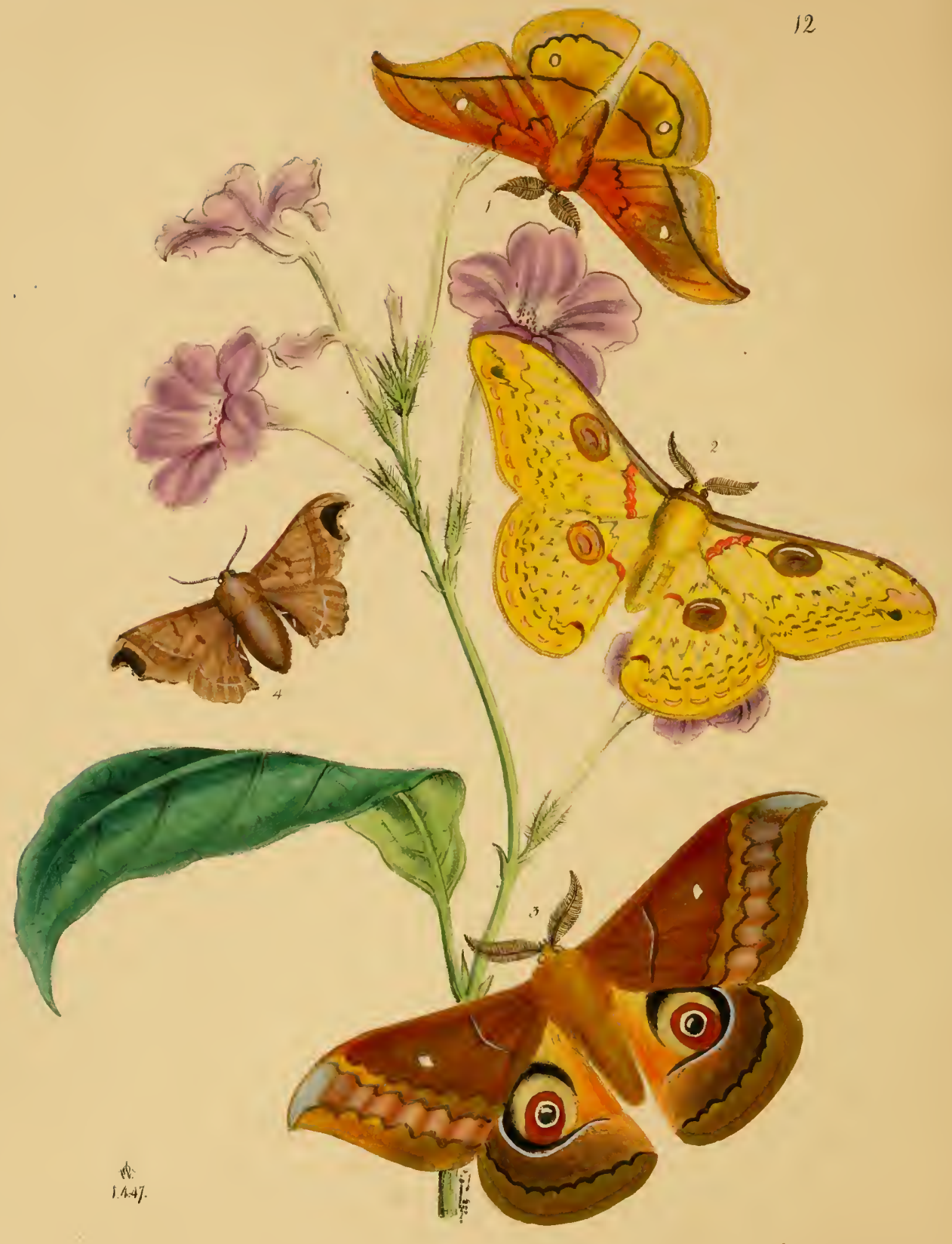




PLATE XII.

(ORDER-Lepid OPtera. Section-Noctoris, Family-Bombycid.e, Leach.)

FIGURE 1.

SATURNIA ZULEIKA. Westw.

Saturnia alis supra fulvo-rufis versus Lasin purpureo parum coloratis singulaque ocello parvo vitreo ornata ; anticis faleatis striga undata fere obsolcta ante medium alterange fere recta plumbeo-nigra postica; posticis strigis duabus plumbeo-nigris, una ante, altera pene medium, hac undata et minus distincta.

Saturnia with the wings above fulvous red, with a purple tinge near the base, each marked in the middle with a small talc-like ocellus; the fore wings falcate, with a small uudulated striga, nearly obselete before the middle, and another beyond the middle, much darker, leaden-black and nearly straight (extending from near the apex towards the middle of the inner margin, the tip stained with purplish chocolate and the outer margin with grey), hind wings with two leaden black striga, one nearly straight and darker before, and the other waved beyond the middle, onter margin yellow-grcy. The female has the fore wings net quite so faleate, the celem's less brilliant, the eccllus of the hind wing nearly obsolete, and with a small grey patch between the ocellus of the fore wing and the costa.

Expansien of the fore wings, $3+$ inclies.

Inlabits Sylhet and $\Lambda$ ssam.

Onservation.-The speeimen represented in the plate is a male belonging to H. G. Harrington, Esq. The female was sent to me from Assam, by Major Jenkins.

FIGURE 2 .

SATURNIA KATINKA. WESTw.

Saturnia alis flavis, costa anticarum grisea, singula oculo magno fulvo-brumneo iride purpurascente, lunula tenui alba pupillaque angusta nigra; pene medium triplici serie strigarum nigrarum valde undata et dentata, interna ebseletiori, exterua alarum anticorum in macula nigra subapicali termiuata, lunulisque augustis, submarginalibus albis; anticis fascia dentata pallide resea subbasali maculaque apicali fulva; posticis etiam striga abbreviata ad angulum ani rosea,

Saturuia with all the wings yellow, the costa of the fore ones grey; each with a fulvous brewn eye-like spet, having the middle purplish, swmeunted by a curved white streak, and berdered with a slender black line, beyend the middle of each wing is a triple series of very slender greyish-black liues, very much waved and dentated, the innermost of which is mest obsolete and the outer ene terminates near the tip of the fore wings in a black demi-oval spot, fellewed by a fulvous apical dash with twe white apical lunules, and a submarginal series of vcry slender pale lunules in all the wings ; the fore wings have moreover a pale resy dentate fascia, near the base, and the hind enes an abbreviated one of the same coleur near the anal angle.

Expansion of the fere wings, nearly 4 inches.

Inhabits Assam and Sylhet. In the Collections of the British Museum, the Rev. F. W. Hope, the Ashmolean Museum, dc.

FIGURE 3.

SATURNIA LOLA. WESTW.

Saturnia alis supra brunneo-rufis, anticis striga transversa elscuriori versus basin, ocello parvo vitreo medio ; striga tenui nigricanti dentata pone medium fasciaque lata transversa griseo-fusea utrinque dentata, margine externe parallela apiceque griseo, pesticis basi pallide griseo, in medio circulo magno incompleto nigro, eculum rufo albo nigroque variegatum includente; fascia fusca submarginali extus linea subdentata terminata.

Saturnia with the wings above rich brewnish red; the fore ones with an obscure transverse striga near the base ; a small somewhat diamond shaped talc-like ocellus in the middle, followed by a dentated darker striga, beyond which is a broad grey-brown faseia dentated en each side, terminatiug at the apex in a grey patch ; hind wings pale yellowish grey at the base, with a large incomplete black circular mark inclesing an eye-like spot, with a black centre, a white ring and a breader red outside; behind this the black mark extends transversely to the anal margin, and beyond this is a broad red-brown indistmet fascia, outwardly edged with a slender darkcr brown dentated striga.

Expansion of the fore wings, $4 \frac{3}{4}$ inches.

Inhabits Syllhet. In the Collection of H. G. Harrington, Esq. 


\title{
FIGURE 4.
}

\section{BOMBYX HUTTONI. WESTw.}

\begin{abstract}
Bombyx alis anticis falcatis griseo-albidis strigis nonnullis ante et pone medium obscurioribus alteraque submarginali pallidiori plaga magna apicali nigricante, alis posticis fuscis venis pallidioribus strigaque curvata submarginali albida, margine anah albo obhque strigato.

Bombyx with the fore wings falcated of a greyish-buff colour with two or three very indistinct darker strigæ before the middle, and two straighter beyond the middle, followed by a submarginal paler space which is contracted into a striga towards the tip by a large blackish apical patch; the hind wings are chocolate-lorown with paler veins and with a whitish curved submarginal striga. The anal margin obliquely streaked with white, and with a tuft of dark scales at the anal angle.

Expausion of the fore wings, $2 \frac{1}{4}$ inches. Inhabits Mussooree. (Capt Hutton). In my Collection.
\end{abstract}

Observations. - I have named this species in honour of Captain Thomas Hutton, by whom it was lately discovered, and to whom I am indebted for a specimen, accompanied by the following interesting observations on its habits:-

"I have the pleasure of sending you a species of Bombyx, which I think will prove new. It is au inhabitant of these hills (Mussooree), and the caterpillar, like that of B. Mori, feeds on the leaves of the wild mulberry which grows here in our forests. Unlike the larva of B. Mori, however, the present species has the caterpillar covered with long spines, although in colouring and shape there is great similarity between the two. The cocoon is spun in the leaf which is drawn round it, and the silk is very fine, and of a very pale yellow tint. I have inclosed an empty cocoon, in order that you may if you please give me your opinion, and that of those interested in such things, as to whether it might not be turned to good account, as I think I could succeed in growing it here if the silk is approved of. I discorered this species on the 7th of May, 1512, on some mulberry trees growing at an elevation of about 6500 feet above the sea, with a southern aspect. Some of the caterpillars were of large size, and nearly full grown at this time, whilst others were in all the intermediate stages of growth. The caterpillar is of a pale yellowish cream-colour, mottled or marbled down the back and sides with a mixture of grey, ycllow and rufous or brownish lines; the anterior segments of the body are mottled above with livid grey and ornamented with four blackish oblong spots or ocelli placed obliquely; along the back are two rows of long black spines curving backwards, and on the anal segment is one long spine in the middle; the two anterior pair of spines spring from the ocelli, and the last pair are curred forwards instead of backwards like the rest; there is also on each side a row of short spines springing from the base of the true legs. The anterior segments swell up into a hump like those of the larva of B. Mori. As the caterpillar becomes mature, the rufous colouring fades away and gives place to a mottling of pale livid grey; the head is also mottled. It grows to about $2 \frac{1}{2}$ inches in length, and spins in the leaf early in May. They are double brooded, for mine all hatched in June, and deposited their ora, a few of which produced caterpillars that year, but the greater number remained until the following spring."

I cau but congratulate Captain Hutton on the discovery of another species of silk moth which seems likely to become decidedly worthy of cultivation. The flossy external portion of the cocoon sent, is very fine and tough, but of a much less silky feel than that of the B. Mori. The injury caused by the escape of the moth prerented me from unwinding the cocoon sent by Captain Huttou. It would be very interesting to know whether B. Huttoni would bear transplanting like the common species. The investigation of the merits of the silk cannot, however, be in better hands, as Captain Hutton has already published a valuable little work, entitled, "Remarks on the Culture of Silk at Candahar." 8ro. Swansea, 1843 .

Eranthemum montanum, an acanthaceous Indian plant, accompanies the figures of the moths. 


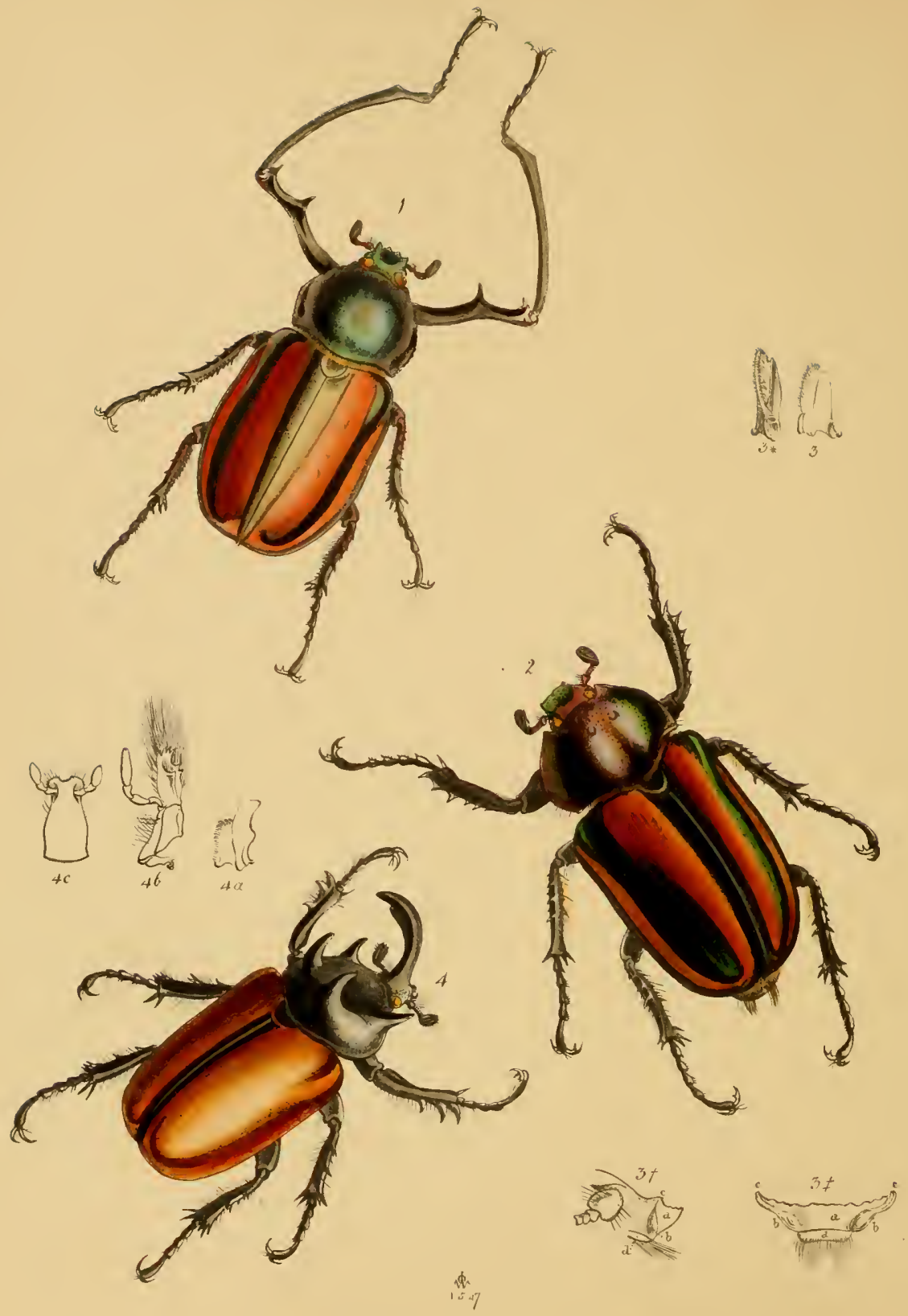






\title{
PLATE XIII. \\ (ORDER-COLEOPTERA. SECTION-LAMELLICORNIA.) \\ EUCIIEIRUS DUPONTIANUS. Bermeister.
}

Figure 1, Male; Figure 2, Female.

\begin{abstract}
Eucheirus aneo-niger, subtus griseo-hirtus; elytris vitta longitudinali prope suturam alteraque submarginali (postice connexis) fulvo-rufis ; tibiis anticis maris valde elongatis extus versus apicem subangulatis; intus inermibus, liaud peuicillatis; prothoracis lateribus ejusdem sexus subserratis.

Eucheirus brassy-black, clothed beneath with grey hairs, each elytron having a broad longitudinal red streak parallel with the suture, and another narrower one dear the lateral margin, united together behind; the fore tibiæe of the male long and slender, slightly angulated externally near the tip, and simple along the inside, without a brush ol hairs at the tip ; the sides of the prothorax in the same sex slightly obtusely serrated.

Length of the insect, about $2 \frac{1}{4}$ inches.

Inhabits the Philippine Islands. Male in the Collection of M. Dupont. Female in the British MIuseum.

Srxonrmes,-Euehirus Dupontianus, Burmeister in Germar, Zeitschrift, f. d. Entomol. iii. 227 ; Genera Insectorum, fasc. 8 tab. Euchirus, fig. 1 (copied in my plate); Handb. d'Entomol., iii. p. 701. (Male).

Euehirus 4-lincatus, Waterhouse, Proceedings of Entomol. Soc. 1841, p. 22
\end{abstract}

Orservations. - In retaining the specific name of E. Dupontianus for this finc insect, I follow a long recognised principle, namely, that the name giren to the male of a species should prevail over that given to the female, especially in cases where priority of date may be doubtful.

In the first plate of this rork both sexes of another magnificent species of this curious genus are figured; and I have now the pleasure of representing both sexes of the Philippine Island insects. The species of the group with which we are now acquainted, are, therefore-1. E. longimanus; 2. E. Dupontianus ; 3. E. MacLeayanus; and 4. E. bimucronatus (Arbaces, Newm.); all of which I consider to belong to one genus, forming as many sections, thus-

A. Fore legs of the males very long, with the tibix externally not armed with a row of spines.

a. Fore tibire of the males without internal spines, prothorax not very coarsely punctured.

* Fore tibix of the males furnished within with an apical brush of hairs. Species 1. Euch. longimanus.

** Fore tibire of the males without an apical brush of hairs. Species 2. Euch. Dupontianus.

b. Fore tibiæ of the males armed with two large spines on the inside. Species 3. Euch. MacLeayanus.

B. Fore legs of the males moderately long, internally setose, externally armed with a row of spines. Species 4 . Euch. bimucronatus.

The last-named species agrees so completely with the other species in the parts of the mouth (Mr. Melly having kindly allowed his specimen to be dissected during the risit of Dr. Burmeister and myself to Liverpool), that I cannot agree with the learned Professor of Halle, in separating it generically on account of the peculiar armature of its fore feet, and the irregularity of the front of the clypeus.

The figures indicated by the No. 3 at the foot of the plate, are introduced for the purpose of showing 
the peculiar character of the front of the head, and the structure of the mandibles taken from the male of $\mathrm{E}$. Mac Leayanus; these characters being of importance in determining the relations of the group.

No. 3 represents the mandible seen from above, and $3 *$ as seen along its inner margin to show the molar plate at the base, which is oval with elevated margins, and with a raised transverse bar or carina. No. $3+$ represents the front part of the head seen sideways; $a$ being the inflexed front of the clypeus, $b$ the swollen oblique lateral margin, $c$ its lateral angle, and $d$ the upper lip. $3 \ddagger$ represents the same part seen from the front, lettered as in the preceding figure.

\section{FIGURE 4.}

DYNASTES HARDWICKII, Hope, in Zool. Misc. (1831) p. 22.

\footnotetext{
Dynastes niger nitidus, capite maris cornu longo erecto recurvo, pronoto maris cornubus 4 robustis antice porrectis (scil. 2 ad angulos anticos alterisque duobus disci postice positis) elytris fulvo-castaneis vitta snturali tenui nigra, tibiis anticis maris extus 3 -dentatis.

Dymastes black and glossy, the head of the male with a long erect recurved hom, the pronotum in the same sex with four strong horns bent forwards, namely two at the anterior angles, and two on the dise beyond the middle; the elytra are fulvous-chestnut coloured, with a slender sutural black streak, and the fore tibiæ of the males are arned on the outside beyond the middle with three strong teeth.

Length of the male, about 2 inches.

Inhabits Nepaul (Gen Hardwicke). In the Collections of the British Museum, Entomological Society, the Rev. F. W. Hope, \&c.
}

Figure $4 a$ represents one of the mandibles, $4 b$ one of the maxillæ, and $4 c$ the lower lip of this species; from which, upon a comparison of them with the dissections of Dynastidæ, engraved from my drawings in the first part of the Rev. F. W. Hope's "Coleopterist's Manual," it will be seen that it approaches nearest to Strategus Alœus; it is still, however, nearer to Dicastes Endymion in this respect. A figure of the species has lately been published in the Journal of the Asiatic Society of Bengal, n. s. No. 54, by Captain Boys. 


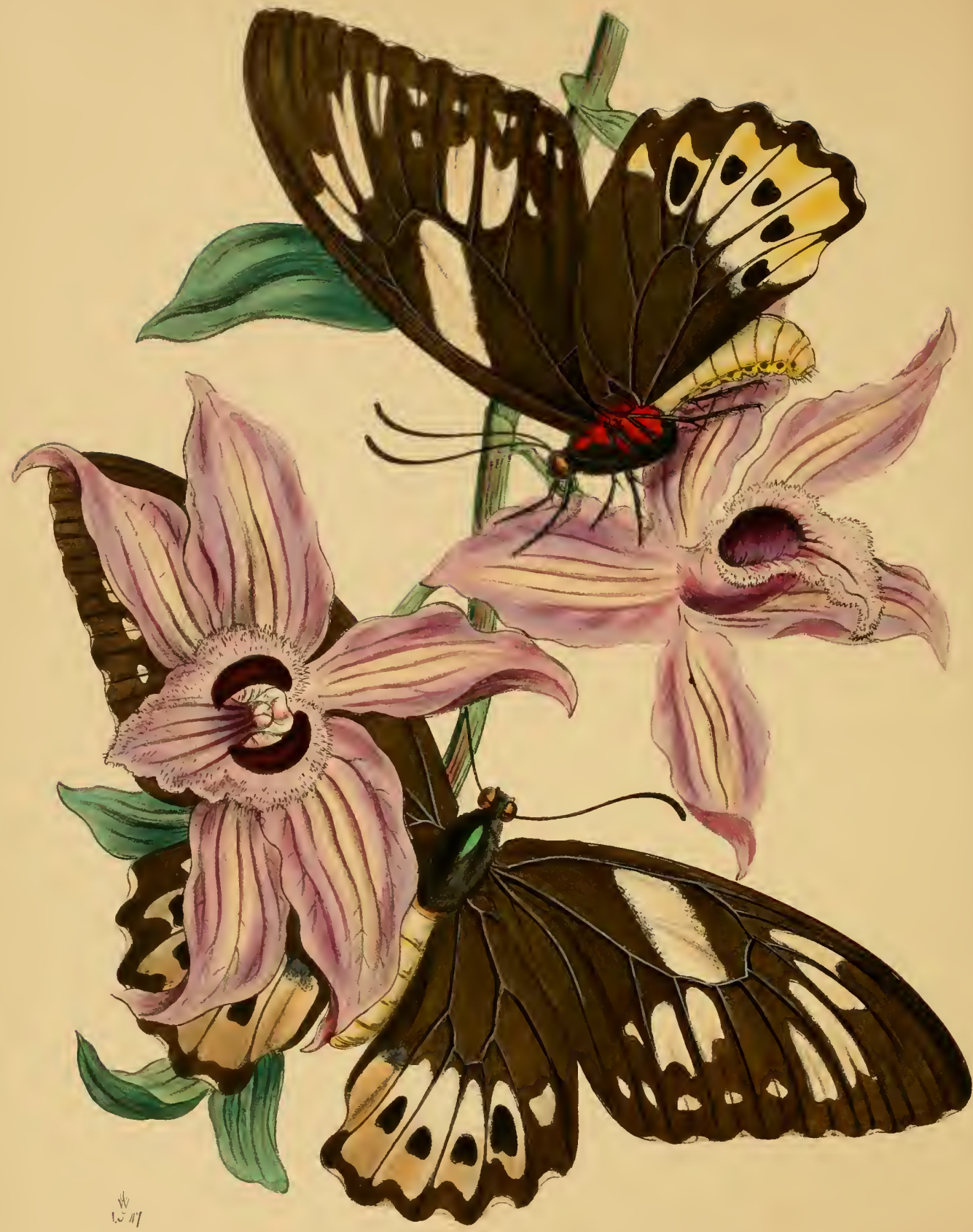






\title{
PLATE XIV.
}

(ORDER-LEPIDOptera. Sectiox-Ditria. Family-Papiliontde. Leach.) ORNithopterus poseidon. E. Doubleday. (Female.)

\begin{abstract}
Ornithoptcrus alis fusco-nigris; anticis fascia lata abbreviata curvata submediana (e maculis 4 constanti); maculisque 9 submarginalibus ( $t$ anticis elongatis), albidis ; posticis pone medimm macula magna irregulari subalbida, venis dirisa et maculas 4 fuscas minores includente. (i)

Ornithopterus with black-brown wings; the anterior haviug a mather broad oblique very pale buff bar across the discoidal cell, near its extremity, beneath which are three other irregular spots of the same colour; followed by nine submarginal spots of the same colour, the four anterior of which are elongated; the hind wings are marlied heyond the middle with a large dirty whitish-luff patch, divided by the veins, extending to the anal angle, and bearing four smaller dark-brown spots. The wings on the underside are coloured as above, the colour of the pale marking of the hind wings being clearcr, with a yellow shade beyond the dark spots. The thorax las a short brilliant green dash on the upper side, and the sides beneath the wings are brilliant crimson. The abdomen, above, is dirty buff; beneath, golden yellow, with black dots (Female).
\end{abstract}

Sixcr. the publication of the last Part of this work I have been favoured, by W. H. Ince, Esq., with an opportunity of figuring the female of the beantiful species of butterfly, the male of which is preseuted in Plate XI., which was captured by his brother, Commander J. M. R. Ince, of the Royal Navy, who has furnished the following particulars relative to its capture:- "This large butterfly came from Cape York, N.E. Cape of New Holland. It is common at Darnley Island, Torres Straits; the natives decorating their hair with them, but more especially with the males. [PI. XI.] I procured the spccimeu figured in Plate XIV, in Febrnary, 1S45, when in H.M. ship Fly. I had a rery beautiful specimen of a male, which I caught during the September preceding, but I gave it to my friend, IV. M'Leay, Esq., of Sydney. They were caught within fifty yards of the beach, near the fiesh water holes."

The female above described differs from the female of Orn. Priamus (Panthous, Clerck. Icon. t. 19) in liaring the dark colour of the upper surface of the wings of a uniform tint, not darker along the apical margins, in the large oblique patch traversing the discoidal cell of the fore wings, and in the pale spots of the hind wings extending to the anal angle. An insect, which scarcely differs from the female here figured, is represented by Boisdural, in the Entomological Plates of the Voyage de l'Astrolabe (Pl. IV. fig. 1 \& 2). It is from Celebes, and is given in the Species général des Lépidoptères, as a variety of Orn. Priamus.

The following is Dr. De Haan's description of the male variety of P. Priamus, mentioned in a preceding page (24), from the South-West coast of New Guinea, which seems to be rery nearly allied to O. Poseidon, male. I am indebted to Dr. Horsfield for a translation of De Haan's description. It has the hinder wings abore without spots, and the anal angle beneath yellow.

"Smaller [than O. Priamus]. Expansion of the wings six inches. Auterior wings; brown spot under the median vein longer, lyeginning at the fourth branch. Median vein bordered with green. The posterior wings have no black spots on the greeu patch. Underueath the anterior wings have the 
discoidal cell marked with a green spot, extending half its length; and the green spots between the veins are separated from each other by a broader black band. The anal angle of the posterior wings is yellow with a small black spot; the patch in the middle is yellowish green; the golden yellow marginal spots between the first reins are wanting; the six black spots are smaller."

The beautiful plant represented in the plate is the Dendrobium Macranthum (Lindley), a native of the Philippine Islands. 


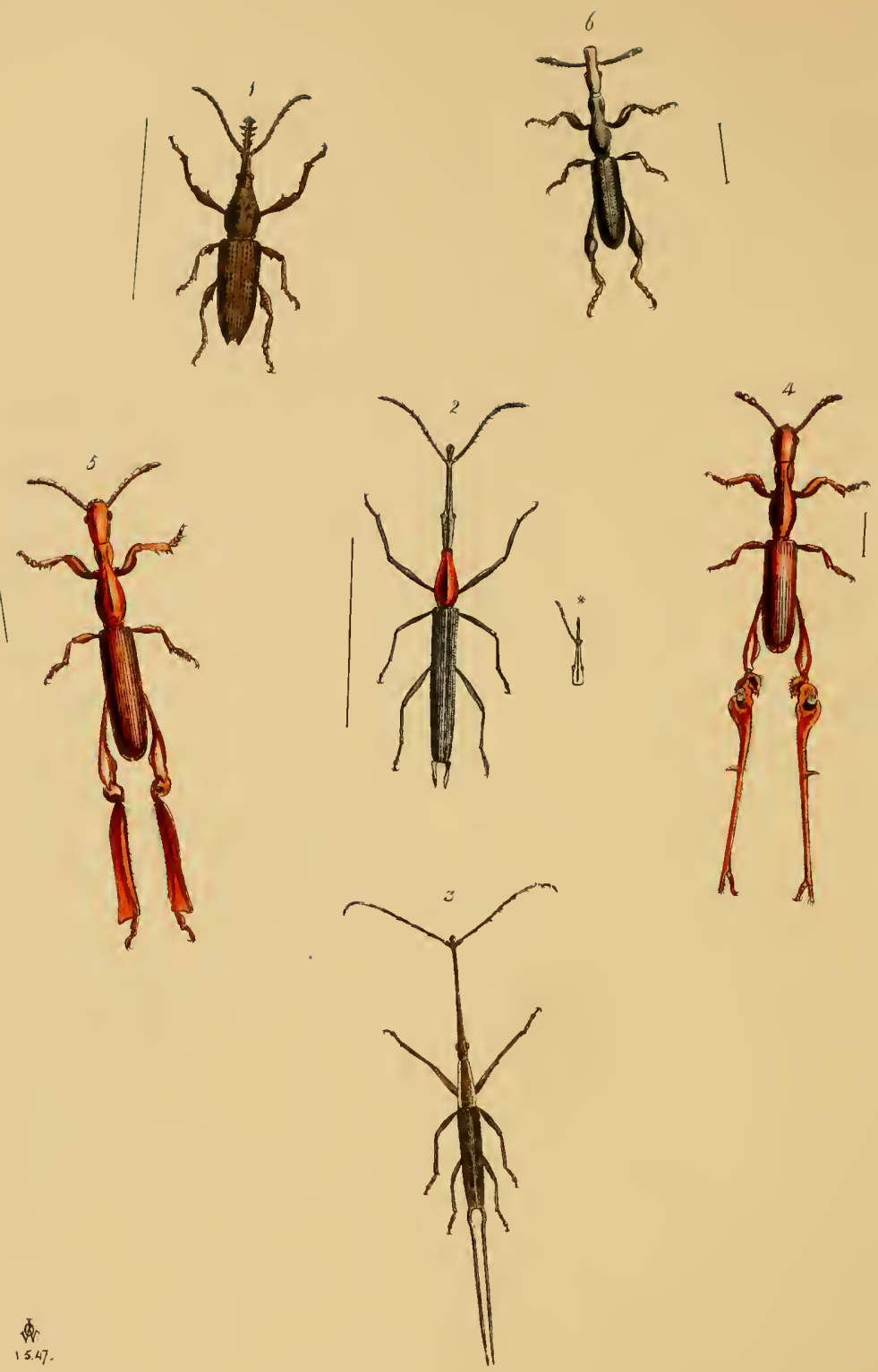






\title{
PLATE XV.
}

(ORDER-COLEOPTERA. Dirision-Psednotetranera. Sub-kamily-Brexthides. Westw.)

FIGURE 1.

ARRIIENUDES XIPHIAS. WEST.

\begin{abstract}
Arrhenoles fuseus, obscurus, luteo-squamosus, rostro, ante insertionem antennarum utrinque serrato, elytris profunde striato-punctntis, coneoloribus, cruce Sti Andrea obscure rufa in medio pietis.

Arrhenodes of an obseme brown eolour, with minute luteous seales; the rostrum in front of the autennæe on each side armed with 5 eonical teeth (the basal ones smallest), the dise of the pro-thorax with several very olseure blaek patches, the elytra deeply striato-punctate, concolorous, marked in the middle with an obseure red St. Anklrew's ('voss.

Length of the Inseet, including the rostrum, 13 lines.

Inhabits Prinee of Wales' Island. Dr. Canton. In the Colleetion of the Rev. F. W. Hope.
\end{abstract}

Observatioss.-This species appears to be allied to the Javanese Arrheuodes serrirostris of Lumd, (Brentus cinnamomeus, Herbst. Col. T. 107, f. 1 Sch. Curc. 1, p. 327), bnt differs at once in its obscure dull brown colour.

\section{FIGURE 2.}

TERAMOCERUS ERYTHRODERES. CheVr. Sch : Curc. Tom, v. p 564.

Teramocerus angustus, ater, opacus, eapite angustiore, erebre punetato, rostro basi bi-canalieulato ; thorace oblongo sanguineo, dorso minus profunde suleato; elytris nediocriter sub.remote striato-punetatis, juxta suturam bistriatis.

Teramocerus narrow, blaek, opaque, with the head narrow, delicately punetured, the base of the rostrum with two ebannels, the thorax oblong, sanguineous, the back moderately grooved, the elytra moderately and rather remotely striato-punctate, with two strice next the suture.

Length of the male (figured) ineluding the rostrum, I3 lines.

Inhabits the Philippine Islands, (D. Cuming). In the Colleetion of the British Museum, Captain Parry, de.

OBservatioss. - The male here figured is distinguished from the female by the insertion of the longer antennæ near the tip of the rostrum and by the extremity of the elytra being truncated and armed at the outer angles with two short spines; the female is much smaller, with the antennæ iuserted in the middle of the rostrum, (fig *) with the extremity of the elytra rounded and obsoletely bispinose.

FIGURE 3.

DIURIS FORCIPATUS. WESTW.

Diuris obscure fuseus granulosus, rostro valde elongato antennarum articulis 7 et 8 albis, pro-thorace elongatoconico utrinque vitta laterali albo-squamosa ; elytris elongatis, subeostatis, spatïs inter costas medias albo squamosis, apice siuguli in caudam gracillimam rectam fere eorporis longitudine producto.

Diuris obscure brown, granulose, the rostrum very muel elongated, with the 7 th and 8th joints of the antennæe white, the prothorax elongate-conic marked on each side with a line of whitish seales, the elytra elongate, brown, with longitudinal raised strixe, the spaces between the three or four next the suture clothed with whitish scales, also with several obscure oblong patehes in pairs down the baek; the extremity of each produeed into a very sleuder straight tail nearly as long as the body.

Length of the Inseet, including the rostrum and tails, 30 lines.

Inhabits Penang. In the Collection of A. Melly, Esy. 
FIGURES 4 \& 5.

CALODROMUS MELLII. GUERN.

(Mag. Zool. 1832, Pu. 34. Boheman Act. Holm. 1837. PL. 6, fig. 1-4).

Male, fig. 4. Female, fig. 5 .

Calodromus rufo-testaceus nitidus, oculis nigris, rostro brevissimo lato, prothorace antice valde compresso, pone medium rotundato-ampliato, supra tenue canaliculato impunctato; elytris striatis, striis obsolete punctatis, interstitiis augustis punetis remotis obsoletis insculptis.

Calodromus rufo-testaceous, shining, with black eyes, the rostrum very short, broad, the prothorax very much compressed in front and swollen into a rourded mass beyond the middle, the upper side slightly channelled, not punctured; the elytra striated, the strixe obsoletely punctured, with the interstices narrow and sculptured with remote obsolete punctures.

Lengtb of the insect $3-4$ lines.

Inhabits the Philippine islands. In the Collection of the British Muscum and A. Melly, Esq.

ObSERVATIONS. - The remarkable structure of the hind feet of this insect and their diversity in the opposite sexes, renders it, notwithstanding its small size, one of the most singular species with which we are acquainted. In both sexes the hind thighs are of the ordinary dilated form, but the following joint or the tibia is in both reduced to a very short thick mass; whilst the basal joint of the tarsi in the male (fig. 4), is nearly as long as the entire insect, dilated and deeply notched at its base and armed near the middle with an erect spine, and with its apex produced beyond the insertion of the remaining three joints of the tarsi. In the female (fig. 5), the basal joint of the hind tarsi is also greatly elongated, but much broader and more regularly formed. In both sexes, indeed, we might say that the basal joint of the tarsus had been elongated iuto a tibia in consequence of the real tibia being almost obliterated. What can be the use of such singular structures?

The genus is certainly very closely allied to Taphroderes, which has the thorax similarly constructed, and with the middle feet, as in Calodromus, much smaller than the anterior ones.

\section{FIGURE 6.}

\section{TAPHRODERES WHITII. W ESTW.}

\footnotetext{
Taphroderes niger nitidus; rostro brevi lato, piceo, prothorace antice contracto postice rotundato-ampliato, disco punctato ; elytris striis elevatis glabris, interstitio punctatis tibiis ; tarsisque piceis.

Taphroderes black glossy; the rostrum short, broad and pitchy, the antenne short with the clava thichened and three-jointed ; the prothorax narrowed in front, the hind part swollen and the dise punctured; the elytra eiongate, parallel, with shining elevated strix, the interstices between which are punctured; the tibix and tarsi are pitelyy, the joints of the latter irregular.

Length of the insect 4 lines.

Inhabits the Philippine islands. In the Cabinet of the British Museum.
}

Observations.-I am indebted to A. White, Esq., the author of uumerous raluable papers on Entomological subjects, for directing my attention to this very interesting insect in the Cabinet of the British Museum placed under his charge, and whose name I have much pleasure in associating with so curious a species. 



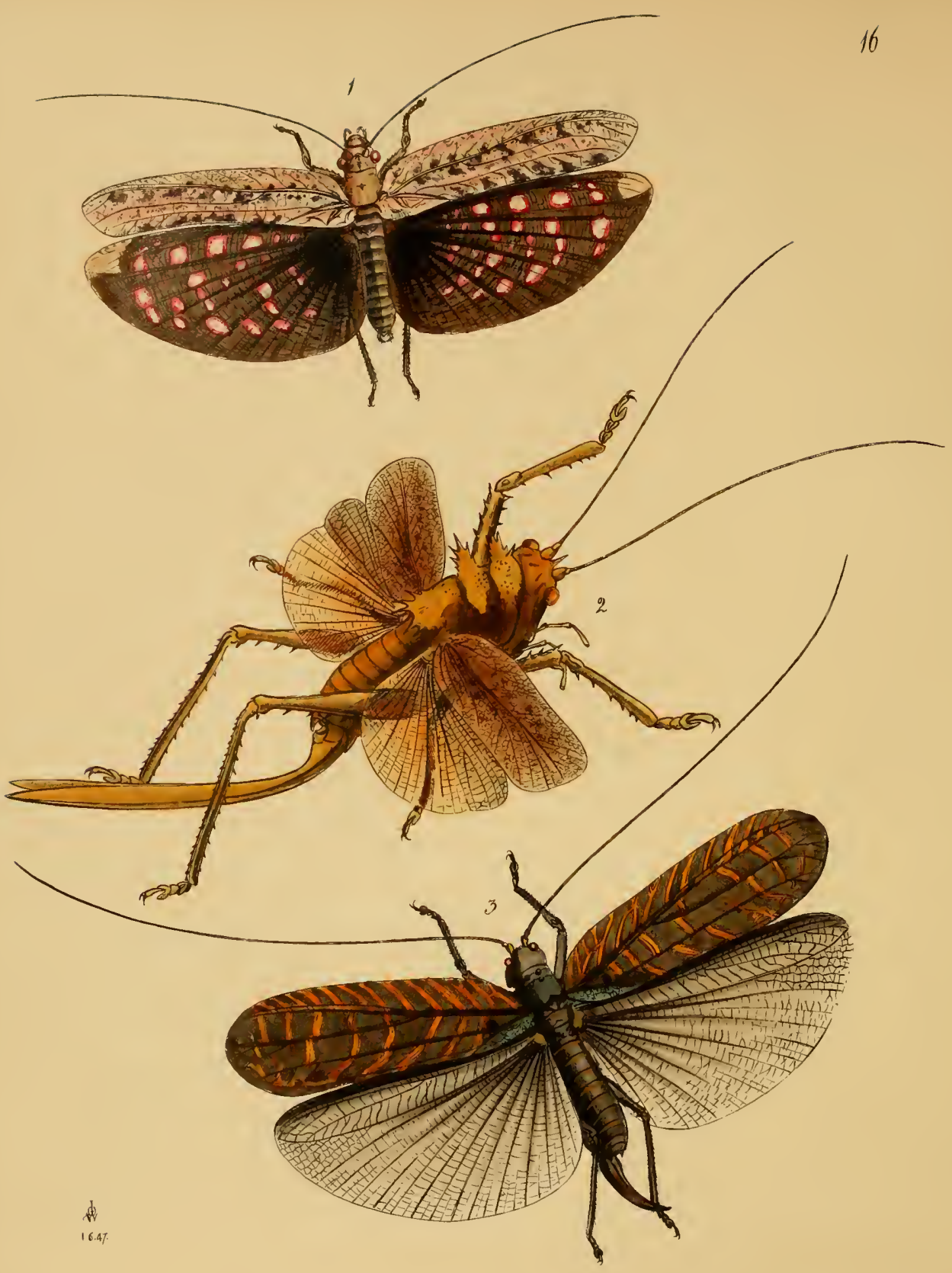






\section{PLATE XVI.}

\section{(ORDER-0Rthoptera. Sectiox-Saltatoria. Family-Grylid.e. Leach. Loctstari.e. Latr.)}

\section{FIGURE I.}

PHANEROPTERA PERLARIA. WESTw.

\footnotetext{
Phancroptera griseo-lutea, tegminibus pallidis purpureo-brunneo irregulariter maculatis, alis fuscis maculis numerosis qualratis albis puxiceo cinctis, apicibus pallidis.

Phaneroptera of a dull lutcous gray colour, with the head and thorax punctured ; the fore wings of a pale brownish colour, irregularly and more or less obscurely spotted, with purplish red-brown spots; the hind wings brown, with numerous square white spots, each margined with a delicate border of pink, the tips very pale brown. (Male).

Expansion of the fore wings 4 inches.

Inlabits Prince of Wales Island (Dr. Cantor). In the Collection of the Rev. F. W. IIope.
}

Descriptron.-The head is sub-horizontal, with a small protuberance between the antennæ and with two others conjoined together immediately behind the former. The palpi are short and pilose. The hind part of the pronotum is slightly prodnced and flat, with a small V-like impression about the middle. The abdomen is brown and glossy, terminating in two short curred setose appendages. The legs are short, pale coloured with dark-coloured spines; the fore tibiæ have the small oval plate at the base; the hind legs are comparatively short and weak. The three sterna are flat and unarmed. The position of the principal veins of the wings will be perceired on examining the Plate, but the fore wings, under a strong lens, are scen to be most densely covered with a net-work of reticulations, which often radiate from certain points in a rery beautiful and unusual manner. The pink colour extends over the greater part of the hind wings, but is for the most part subdued by the brown tint. The general appearance of the inscet is almost as much that of a large Perla as of a grasshopper.

\section{FIGURE 2.}

\section{MEGALODON ENSIFER. Brille, (Hist. NAt. INs. ORTH. p. 157.*)}

Megalodon fulvo-rufus, tegminibus et oviductu guttatis, facie subtus mandibulisque nigris ; corpore supra granuloso; fronte inter antennas spina armato; pronoto utrinque prominentiis duabus posticeque spinosis; oviductu fomin longissimo.

Megalodon of a fulvous red colour, the fore wings and oripositor more or less irrorated with darker and lighter spots; the face below and the mandibles black; the body above finely rugose; the forebead armed with a strong spine between the antennæ; the pronotum armed on each side with two spinose prominences, and the ovipositor of the female very long and sahre-shaped. The wings are short. Each of the three sternums is bispinose.

Expansion of the fore wings 3-3 3 inches.

Length of the female insect, including the ovipositor, nearly $4 \frac{1}{2}$ inches. Inlabits Sumatra.

In the Collections of the British Museum, Zoological Society (Sir S. Raffles), and Rev. F. W. Hope.

Srxosyurs.-Mlegalodon ensifer, Burmeister, Handb. d. Ent., vol. ii. p. 724 ; Serville, Hist. Nat. Ins. Orth., p. 537 ; Charpentier, Orthoptera, pl. 9 (male) ; Ditto in Germar's Zeitsclurift, iii, 320 ; De Haan, Bijdragen, \&c. p. 210 .

- The plate referred to by $\mathbf{M}$. Brullé has never been published. 
Obsenvations.-M. Charpentier having figured the male, I have here represented the other sex, which is one of the most singular-looking Orthopterous insects. De Haan describes the female larva from Java as being armed with still longer spines on the pronotum and legs than the perfect insect, and adds, "Het is deze Locusta, door de Javanen Jangkreh op Aduh Jangkrik, Vecht-krekel genaamd, welke zij te zamen in kokers van bamboes vechten. Op den uitslag dezer vechtpartijen houden zij aanzienlijke Weddingschappen, Volgens Raffles, History of Jara, i. 349, en Crawfurd, i. p. 231."

\section{FIGURE 3.}

\section{PSEUDOPHYLLUS 4-TUBERCULATUS. WESTW.}

Pseudoplıyllus fuscus opacus pedibus nigricantibus ; antenuis albo late anuulatis, pronoti disco in medio tuberculis 2, 2, parvis nigris instructo ; margine postico bilobo ; tegminibus obseure-fuscis, basi parum virescentibus ; venis secundariis fulvo-inqninatis naculaque nigra versus basin notatis, alis posticis pallide fuscis area costali fusca, abdomine nigro nitido subtus rufo-fulvo.

Pseudophyllus opake-brown, with black feet, the antennse broadly annulated with white; the middle of the disk of the pronotum with four small black raised tnbercles, the hind part forming two rounded lobes; the wing-covers tre of an obscure brown, tinged towards the base with green, with the secondary veins stained with fulvous, and with a small black spot near the base; the hind wings pale brown, with the costal portion darker; the abdonen black and slining, with the underside fulvous red. (Female).

Expansion of the fore wings, $4 \frac{1}{2}$ inches.

Inhahits Prince of Wales Island (Dr. Cantor). In the Collection of the Rev. F. W. Hope.

Observations. - The legs are destitute of spines; the fore tibiæ are thickened near the base, with a deep slit on each side, forming two raised oval glossy lobes, thus differing from the oval opercula in the fore legs of many of this family. The ovipositor is about half the length of the abdomen, gradually acuminated to the tip. 


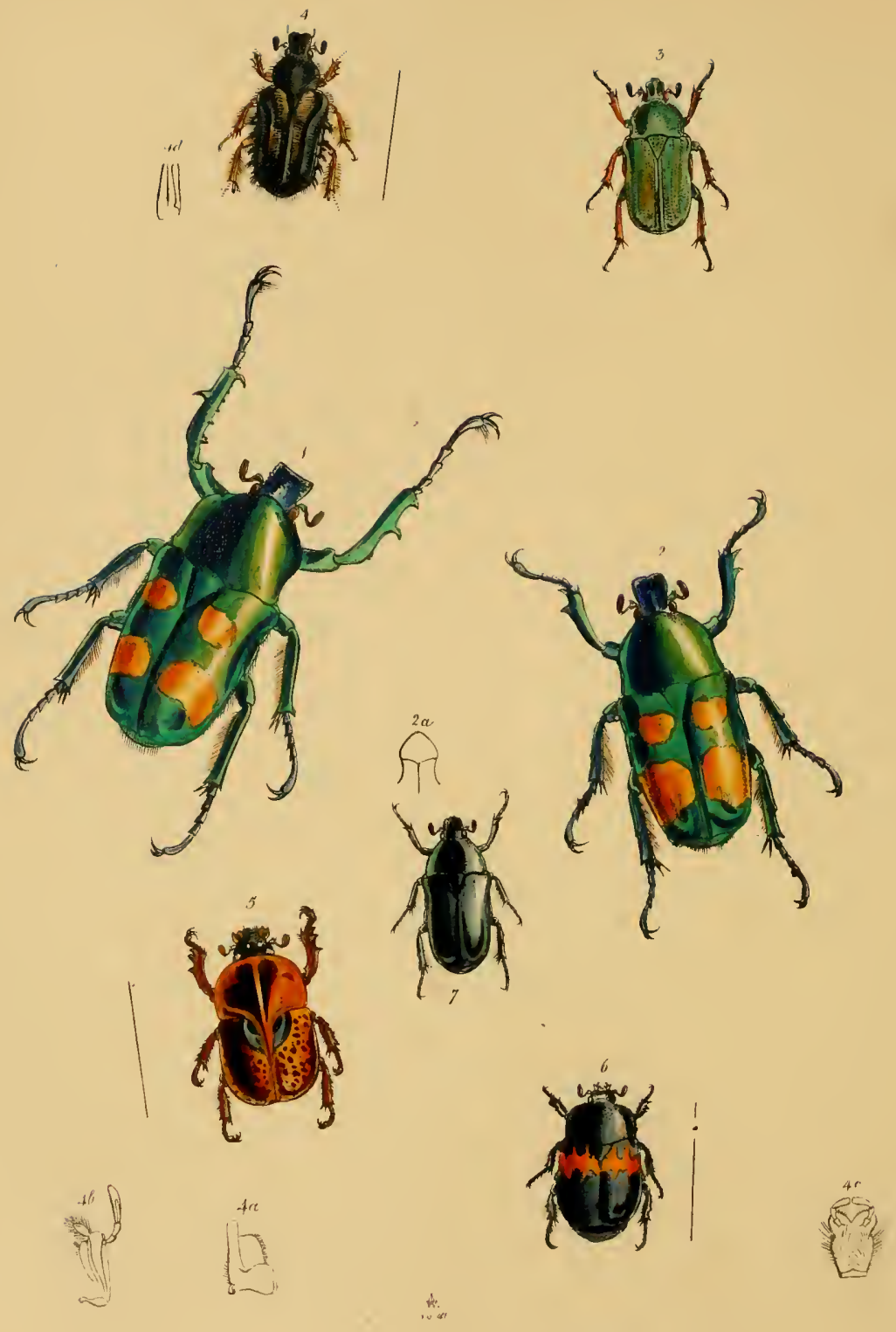





\title{
PLATE XVII. \\ (ORDER-COLEOPTERA. SECTION-LAMELliconia.) \\ JuMNos RUCleri. Saunders, (Trass. Ext. Soc. ii. p. 1i6).
}

Figure 1, Male; Figure 2, Female.

\begin{abstract}
Jumnos lete viridis, politus, vertico tarsisque chalybreis, elytris guttis quatuor flavis, duobus posticis majoribus et in fasciam interruptam dilatatis.

Jumnos of a brilliant polished green colour, with the upper surface of the head and the tarsi stecl blue; the elytra with four yellow spots, the two posterior largest, and forming a broad interupted fascia.

Length of the insect, $1 \frac{2}{3}-1 \frac{3}{3}$ inches.

Inhabits the Himalayas. In the Collection of the British Muscum and T. Norris, Esq. (male), and Captain l'arty (female).
\end{abstract}

ObSERAtjons. - The female of this magnificent Cetonideons insect having been recently received (for the first time) from the Himalayas, by T. Veruon Wollaston, Esq., of Jesus College, Cambridge, I have decmed it worthy of a place in this work, and have added a figure of the male from a specimen presented to the British Museum by II. G. Harrington, Esq.* The head is quadrate, and rather wider in front, especially in the male, which has the lateral margins elevated and rough with uncqual tubcrcles, the anterior margin smooth and elevated, and the upper surface rongh with elevated spots. The pronotum is rery convex, especially in front, in both sexes, the middle of the fore margin swelling into a rounded space, the sides distinctly margined. The epimera are of moderate sizc, being but slightly risible from above. The mesostcrnal process is porrected, and almost triangular (fig. 2 a). The four hind tibiæ of the malc are destitnte of the spur in the middle which is found in J. Roylii, male.t The forc logs of the female are simple in form, and of moderate length, with the tibiæ 3-dentate. The hind tibixe in this sex have a short spur in the middle. The maxilla of the female agree with those of J. Roylii, female (Arc. Ent. I. pl. 29, fig. 2b). The head of this sex is not rugose as in the male.

\section{FigURE 3. HETERORHINA NIGRITARSIS. Hope. Female.}

"Heterorhina obscure smaragdina, elypeo cornuto elytris viridibus femoribus igneo-opalinis," tarsisque nigris.

Heterorhina obscure emerald green, the front of the head produced into a short truncated born; the elytra green, and the femora fiery-opaline colonred, and with black tarsi.

Length 10 lines. Inhabits varions parts of India.

Srwoxrses,-Cetonia nigritarsis, Hope in Gray's Zool. Misc. i. 24 ; Gnathocera n., Gory and Perch. Mon. Ceton.

pl. 20, fig. 3 ; Heterorhina n., Westwood, Arean. Ent. i. pl. 30, fig. 7, 7 a and b, and 8 a, b, c, d, p. 133.

Var. Cetonia mutabilis, Hope loc. eit.

Observations. - The male of this species having hitherto alone bcen described and figured, I am here enabled to represent the opposite sex by the kindness of Dr. Benson, who has furnished me with specimens from Landour. The front of the head is rather more produced and truncated than in the male, the legs shorter, the fore tibixe bispinose, the four hind ones with a central spur. The mesosternal process agrees with that of the male. Dr. Benson informs me that the wild indigo is the favourite resort of this species, as well as of H. Hopei (Arc. Ent. I. pl. 33, fig. 3), the female of which he has no doubt is the H. bengalensis (Are. Eut. pl. 35, fig. 1), as out of huudreds of H. Hopei which he had seen and taken thcre was not one female, whereas all the specimens of $H$. bengalensis proved to be females. The species ought therefore to take the specific name of the male, H. Hopei.

* The head is wanting in this specimen. The middle feet of the unique female are also wanting. From analogy with J. Roylii I I have represented them as similar to the lind feet.

+ Dr. Benson informs me that Jummos Roylii is abundant in the hollows of oaks in the neighbourhood of Landour, and is frequently taken in flight. 
FIGURE 4. BOMBODES URSUS. WESTW.

Char. Gen,-Pronotum parvum, convexum subheptagonum postice supra scutellum parum extensum, mesosternum simplex inerme; tibiæ anticæ et intermediæ extus 3-dentatæ; posticæ 2 inermes; clypeus antice emarginatus. Vertex subcarinatus. Elytra in medio costata. Corpus supra cum pedibus valde pilosum (Affinis Tænioderæ et Chromoptiliæ) Fomina.

Bombodes nigra eapite punctato fere sudo, pronoto nigro-piloso, elytris in medio fusco pilosis lateribus nigropilosis ; pedibus fulvis fulvo-pilosis, femoribus basi obscurioribus.

Generic Character.-Female. Pronotum small convex, somewhat 7 -sided, produced behind over the base of the scutellum; mesosternum simple and unarmed; anterior and intermediate tibixe outwardly armed with 3 spines; posterior pair unarmed; clypeus emarginate in front; elytra with a raised ridge down the middle ; the upper side of the body and legs very pilose. (Allied to Tæniodera and Chromoptilia).

Bombodes black, with the head nearly naked, black, and punctured; the pronotum thickly clothed with black hairs; the elytra in the middle with brown hairs; the sides with black hairs; the legs fulvous, with fulvous hairs ; the femora darker at the base. Length of the insect 10 lines.

Inhabits the Himalayas. In Mus. Westwood. Communicated by H. G. Harrington, Esq.

Figure 4 a, represents the mandible, $4 \mathrm{~b}$ the maxilla, $4 \mathrm{c}$ the instrumenta labialia, aud $4 \mathrm{~d}$ the spurs of the hind tibiæ, all magnified.

Fig. 5. Peperonota harringtonit. Male. Westw. Trans. Ent. Soc. vol, iv. p. 296, Pl. 22, Male, Female, and details.

Peperonota obscure luteo-fulva $(\delta)$ vel nigra $(q)$ capite supra nigro, antennarum elava fulva, pronoto maris fulvo, diseo brunneo, foeminæ nigro, punctato ; elytris luteo- vel castaneo-fulvis, maculis minutis irregularibus plus minusve confluentibus notatis.

Peperonota obscure fulvous-clay-coloured in the male, or black in the female; the head above black ; the club of the antennæ fulvous, the pronotum of the male fulvous, with the disk rich brown, that of the female black and punctured; the elytra clay or chesnut-fulvous, with minute irregular brown, and more or less confluent spots.

Length of the male 10 lines, of the female 9 lines.

Inhabits the Himalayas. In the Collections of A. Melly, Esq., and Captain Parry. Communicated by H. G. Harrington, Esq.

Observations.-As a series of outline figures of both sexes of this very singular new genus accompany my description in the Transactions of the Entomological Society, I have thought it sufficiently interesting to represent it in its natural colours in the present Work. The female is destitute of the singular horn which extends over the scutellum of the male, of which I am acquainted with no other instance among the beetles. The genus belongs to the family Rutelidæ, and is nearly allied to Parastasia.

FigURE 6. PARASTASIA RUFo-PICTA. Westw. (Trans. Ent. Soc. iv. p. 93).

Parastasia nigra vitida tenuissime punctata, fascia irregulari rufa prope basin elytrorum, iu singulo elytro antice biramosa et postice in medio late emarginata (Fœemina.)

Parastasia black, very glossy, and very delicately punctured (when seen through a lens); an irregular fulvous red fascia near the base of the elytra, emitting (in eacls elytron) two straight branches in front, and being very deeply notched in the middle behind. Length of the insect 11 lines.

Inhabits Sylhet and Assam. In the Collection of Captain Parry and myself. Communicated by Major Jenkins.

FIGURE 7. HETERORHINA ANTHRACINA. WESTW.

Heterorhina uigra, nitida, levis, pronoti lateribus, pygidio, pectore pedibusque subtus viridibus, capite punctato, clypeo in medio parum angulato-producto apice emarginato; vertice carina simplici; elytris sub lente parum punctato-striatis; tibiis anticis extus ante apicem subemarginatis; tibiis 2 posticis extus in medio calcari minuto armatis, intus præsertim ad apicem fusco pilosis (mas.)

Heterorhina glossy black, smooth, the sides of the jronotum, the podex, breast and underside of the legs green; the head is punctured with the clypeus angularly produced in the middle, the tip being slightly emarginate; the vertex has a simple cariua (not dilated or free in front) ; the elytra (under a lens) exlubit several rows of minute punctures; the fore tibiæ at the tip on the outside are slightly emarginate; the two posterior tibiæ are armed with a small spur in the middle of the outside, and are clothed on the inside,especially at the tip, with brown hairs (male.)

Length of the insect $10 \frac{1}{2}$ lines.

Inhabits Upper India. Communicated to Col. Hearsey by Dr. Bacon.

Observations.-This new species comes close to H. olivacea, Guérin. (Westw. Arc. Ent. I. pl. 35, fig. 7 ; H. Surrya, Hope), having the same-formed mesosternal process. It is rather narrower, however, and especially differs in the structure of the head and in its highly-polished and smooth surface. 
. 


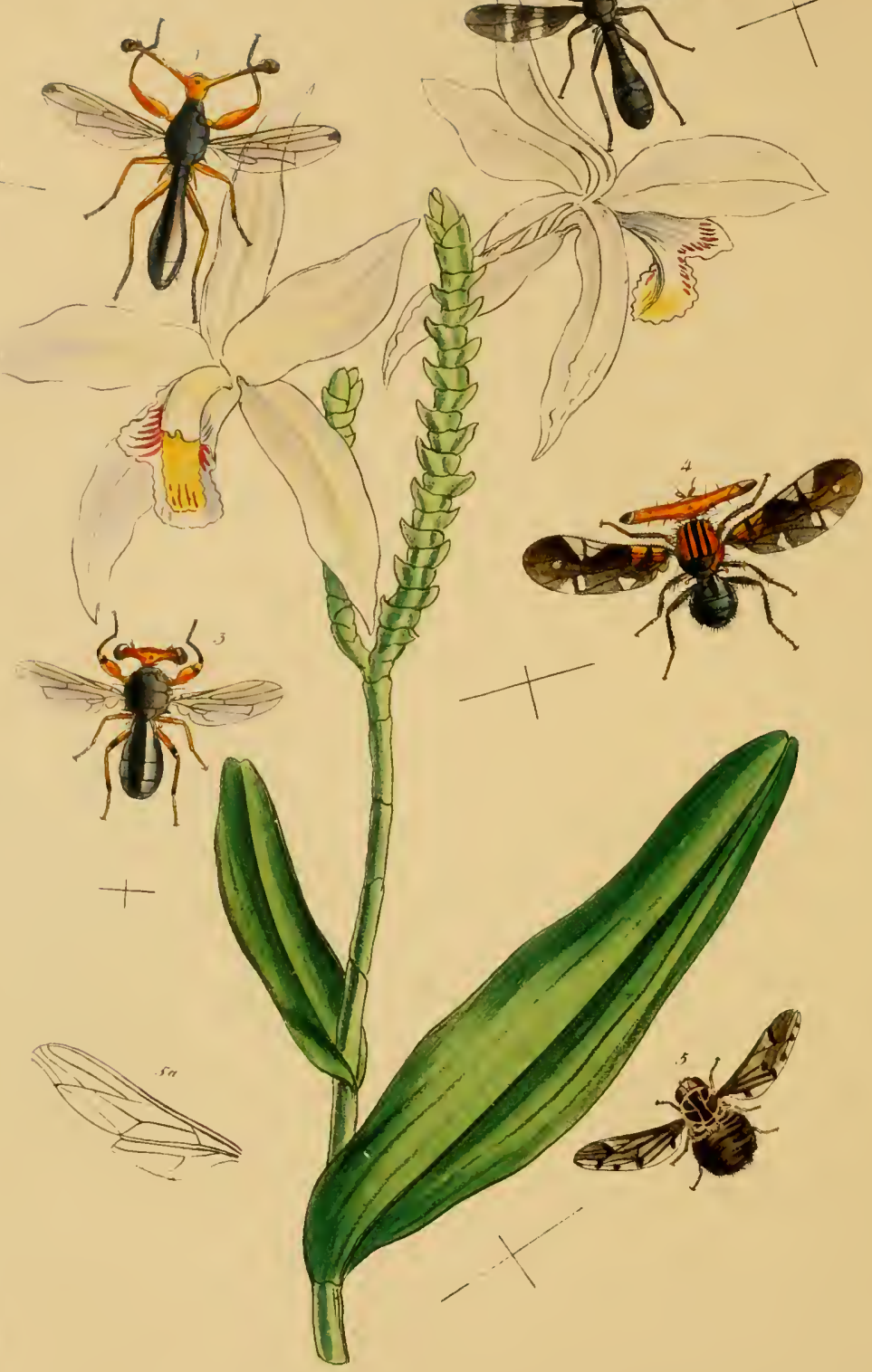





\title{
PLATE XVIII. \\ (ORDER-DIPTERA. \\ Section-Athericera. \\ FANILY-MUSCID.E.)
}

FIGURE I. DIOPSIS WESTWOODII. DE IIAAX.

\begin{abstract}
Diopsis capite fulvo, pedunculorum oculiferorum apicibus obseuris, thorace obseure nigro, abdomine glaberrimo nigro, dimidio basali articuli $1 \mathrm{mi}$. picco ; pedibus fulvis, tibiis apice tarsisque obscuris, atis hyalinis macula apicali nubilaque temui media longitudinali obscuris.

Diopsis with the head fulvous, the tips of the ocular peduncles with the eyes brown, the face marked above with a black angulated streak, and terminated benenth in two short spines; antenne fulvous; the thorax scriccous, obscurely black, not shining; the seutellar spines fulrous; the abdomen very glossy and black, with half of the basal joint tinged with pitchy red in certain lights ; the feet fulvous ; the fore tibire except the base and the cxtremity of the other tibise and the cntire tarsi dusky ; wings hyaline, with a dusky apieal spot, and a dash arising from the eentral transverse vein. Expansion of the fore wings 7 lines.

Inhabits the lsland of Jara. Conımunicated by M. De Haan, with the MS. name adopted above.
\end{abstract}

FIGURE 2. DIOPSIS SUBNOTATA. WESTW.

Diopsis nigra, opaca, pedunculis oculiferis parum elongatis, abdomine maculis lateralibus cinereis fere inconspicuis, alis nigricantibus fascia hyalina ante alteraque subinterrupta pone medium, apicibusque minus infumatis.

Diopsis black opake, with the ocular peduncles rather short; the sides of the abdomen very obscurely marked with asliy triangular spots indieating the base of the segments; the wings dusky, with a hyaline fascia crossing them before, and another more interrupted beyond the middle of the wing, the tips paler.

Length 6 lines. Expansion of the wings $8 \frac{2}{2}$ lines.

Inhabits the Philippine Islands. In the British II useum.

FIGURE 3. SPHRYRACEPHALA HEARSEIANA. Westw., Proc. Ext. Soc., Lond. Ist Jan. 1844, p. 99.

Sphryracephala brevis robusta, capite fulvo, nigro vario, cornubus oculiferis abbreviatis crassis, apice nigris; thorace griseo-nigro, spina brevi utrinque sub basin alarum aliisque duabus ad apicem scutelli albidis longe setigeris; abdomine nigro nitido; pedibus flavescentibus femoribus anticis intus fusco maculatis tibüsque anticis nigris; alis hyalinis.

Sphryraceplala short robust, the head fulvous, varied with black; ocular peduncles short and thick, black at the tips; thorax greyish-black, with a short spine on each side beneath the base of the wings, and two others at the extremity of the scutellum, buff coloured, and terminated by long hairs; the abdomen black glossy; the legs flarescent, with the fore thighs marked with brown on the inside near the tips; the fore tibiæ black ; wings hyaline.

Length of the insect 2 lines. Expansion of the wings 4 lines.

Inhabits Neemuch and other parts of India. Messrs. Hearsey, Downes, \&c. In Mus. Saunders, Westwood, \&c.

OBservations. - I have adopted the genus Sphryracephala proposed by Say for a congenerous American species, thinking even that it belongs to a distinct subsection of the family from that in which the trpical Diopsis ought to be arranged, as indicated by the different size of the alulets at the base of the wings and the shortness of the epistoma, which is scarcely broader than the oral cavity. Colonel Hearsey informs me that he captured several specimens of the species here figured off his glass doors, and also off the leares of lime or lemon trees and other plants in his garden, in July, August, and September. He thinks they feed on small Aphides,* or some very minute insects of that description, as he never caught them feeding on the honey or pollen of flowers. Some were taken in the middle

* The raptorial form of the fore leg, the thigh of which is armed with a row of very minute spines, would indicate such a habit. 
of August on cucumber leaves. He usually took them separately, and never saw them swarm together like the gnats do in England.*

FIGURE 4. ACHIAS MACULIPENNIS, WeSTw.

\begin{abstract}
Achias fulvus, vertice transverse fuscano, thorace maris vittis tribus longitudinalibus, scutello, et metathorace fuseis ; fominæ fulvo ; abdomine (maris) nigro basi parum fulvo, alis fuseis, maculis duabus fulvis ad basin costæ, aliis duabus ad medium costie, tribus ad marginem posticum punctoque parvo ante apicem hyalinis ; pedibus fuscescentibus articulis tarsisque luteis.

Achias fulvous, with a transverse brown streak on the vertex; the thorax of the male with three longitudinal stripes, the scutellum and metathorax brown; thorax of the female fulvous, abdomen of the male black, with the base slightly fulvous; wings brown, with two fulvous spots at the base of the costa, two others near the middle of the costa, three on the posterior margin, and a small round dot before the tip of the wing, all hyaline; legs brown, with the articulations and tarsi luteous,

Expausion of the wings $\frac{3}{4}$ inch.

Inbabits Java. In the Museum of the East India Company in Leadenhall street, London.
\end{abstract}

Observations. - Both sexes of this fine species were cullected in Java, by Dr. Horsfield, to whose kindness I am indebted for an opportunity of figuring it. The female has the head of the usual size, being small, round, and not so wide as the thorax, which is not streaked with brown, and the abdomen terminates in a point.

The last joint of the antennæ of the male is long, narrow, and rounded at the tip, and the seta is fringed with long setula; the antennæ arise close below a curved slightly-raised carina, which is close below a deeply impressed line which runs to the tips of the ocular peduncles in front. The mouth is luteous, in the middle of a broad dark transverse band. The wings are very broad and the veins curred, which is not the case with A. oculatus. The scutellum is armed with two long erect setæ. The genus has hitherto consisted of only a single species from Java, described by Fabricius, from a unique speeimen in the collection of Bosc, still preserved at the Jardin des Plantes, of which a good figure has been published by M. Guérin Menèville, in his Magazin d'Entomologie, pl. 7. Two other remarkable insects, Zygothrica dispar and Plagiocephala lobularis, have been described and figured by Wiedemann, whose figures are copied into Griffiths' Translation of the Règne Animal.

\title{
FIGURE 5. COLAX ? VARIEGATUS. WESTw.
}

Colax ? fuscus capite subtus, thorace lateribus postice et subtus albo-lirtis ; disco fusco strigis pallidis ; abdomine dilatato fusco-piceo sericeo, strigis transversis obseurioribus; pedibus brevissimis fusco albidis ; antennis luteis, alis fuscis nigro maculatis alboque variegatis; abdomine filamentis duobus elongatis suhtus terminato.

Colax ? brown, with the underside of the head, the sides, under, and hind parts of the thorax clotbed with white hairs, the dise of the latter dark-brown, with pale streaks; the abdomen dilated, pitchy-brown, silky, with obseure transverse fascize; legs very short, dirty white; antenne inserted in a transverse impression in the middle of the face, short, dilated, and obliquely truncate at the tip, luteous; the wings brown, dotted with black, and variegated with white; the abdomen terminated by two long slender deflexed filaments; the mouth appears only as a minute filament ; the tarsi are terminated by three pulvilli.

Expansion of the wings $12 \frac{2}{2}$ lines.

Inlabits China. In the Britisb Museum.

OBSERTATIONs.-Notwithstanding the very rudimental structure of the mouth in this insect, as well as in the genera Colax, Wiedemam, and Trichopsidea, Westw., I am inclined to refer them to the position proposed by M. Maequart (Dipt. Exot. ii. p. 34), namely, in connexion with the Nemestrinæ, in which the mouth is developed to its highest extent. Their relation to the Estridæ appears to me more questionable.

The Orchidaceous plant represented is the Bromheadia palustris, from Singapore and Sumatra.

* Colonel Sykes observes of D. Sykesï, "This insect affects chasms or ravines in the lofty woods which encirele the hill fort of Hurreechunderghur in the western ghauts of the Deccan, in various places. Where the sunbeams occasionally pierce the woods and fall upon isolated or salient rocks in the above localities, they are seen in myriads either poising themselves in the rays, or reposing in the spots on which the rays fall." 



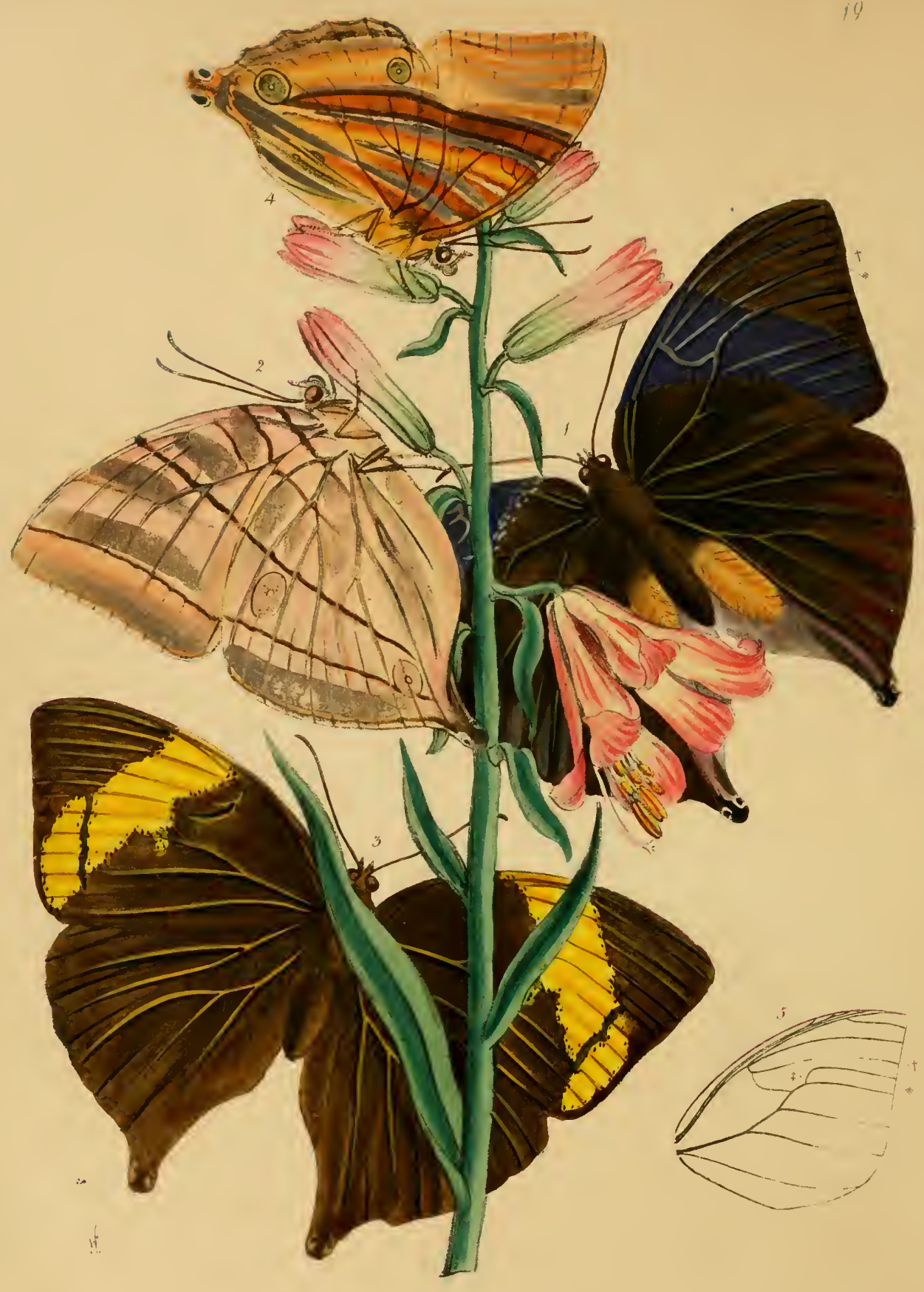






\title{
PLATE XIX.
}

\author{
(ORDER-Lepidoptera. Section-Diura. Family-Nympiladie. Swainson.)
}

Adlatilusia AMYTllaON. E. Dovbleday, (Ann. Nat. Hist. xix. 175, Mareh 1847.)

Figure 1, 2, Male; Figure 3, Fcmale.

\begin{abstract}
Amatlusia alis omnibus supra fuscis ; anticis fascia obliqua lata (in mare late crerulea, in fomiua fulva), subtus pallide ehocoladinis, strigis 7 transversis inequalibus saturatioribus, posticis ocellis duobus albo pupillatis punc. tisque duobus nigris in cauda abbreviata.

Amathusia with all the wings above brown, the fore ones with an oblique broad fascia, light blue in the male, fulvous in the female; beneath all the wiugs pale chocolate, with 7 transverse unequal darker streaks; the hind unes with two oval ocelli having white pupils, and the short tails with two black dots.

Expansion of the fore wings, about 5 inches.

Inliabits Sylhet.
\end{abstract}

Deseription.-Male above, all the wings blackish brown, the basal portions being the darkcst; the anterior are traversed by a broad oblique band of a beautiful light blue with purphish reflections, commencing close to the costa, a little beyond the middle of the cell, and occupying in width about onethird of the costa, extending obliquely across to the inner angle of the wing, terminating near the outer margin, where its upper boundary is the second branch of the median vein. The hind wings have the anal margin of a delicate pale lavender grey, fringed with a very thick row of long pale brown hairs; the anal angle is produced into a rather broad short tail, in which are two small black dots. Bclow, all the wings are pale chocolate coloured, with lavender reflections, the anterior traversed by seven, and the posterior by four richer brown transverse lines, the first crossing all the wings, near the base; the second extending from the costa across the discoidal cell of the fore wings, and terminating near the middle of the discoidal cell of the hind wings; the third very slender, cross. ing the discoidal cell of the fore wings beyond the middle; the fourth extending from the costa of the fore wings and terminating just abore the inner of the ocelli of the hind wings ; the fifth paler and more obliqne, extending only across the fore wings, crossing the third branch of the median vein where it is angulated; the sixth extending from near the apex of the fore wings to the outside of the inner ocelli of the hind wings, beyond which it again reappears for a short distance; and the seventh very slight and submarginal, extending into the anal tail and again ascending along the anal margin of the hind wings. The hind wings are, moreover, marked with two oval ocelli, consisting of a very slender dark brown ring with a white pupil, the remaining space filled with minute irrorations, one near the costal margin, beyond the middle, the other towards the tail, which is marked as above: the body and antennæ are brown.

The female differs in having the wings paler brown, with the oblique fascia of the fore wings much narrower, commencing outside of the discoidal cell, and of a fulvous colour, marked across within the outer margin by a brown waved striga.

Observatioxs. - The male here figured is from the collection of H. G. Harrington, Esq.; the 
female is in the British Museum. The species nearly resembles the Javanese Amathusia Phidippus Limn. (Cram. t. $69+$ A. B.), but differs in the blue band and the markings of the under side of the wings. It also resembles the Javanese Zeuxidia Luxerii of Hubner's Exot. Samml., but the latter speeies has the outer portion of the hind wings glossed with blue, a patch of hairs in the middle of the discoidal cell of the same wings, and a very peculiar arrangement of the veins of the fore wings. Its underside is also quite different.

\title{
FIGURE 4.
}

\section{AMATHUSia Patalena. Westw.}

\begin{abstract}
Amathusia alis supra fulvo-fuscis, fascia communi subangulata valde indistincta et paullo pallidiori submarginali, subtus pallide carneo fuscis, strigis plurimis rectis communibus pallidis fasciaque latiori media obscuriori, ocellisque duobus in posticis, cauda lata bimaculata.

Amathusia with the wings above of a rich fulvous-brown colour, varied only by a somewhat dentated very indistinet slightly paler fascia across all the wings close to the outer margin ; beneath, the wings of a pale fleshy brown colour, with numerous pale straight striga and a broad central dark fascia running across all the wings; the hind ones with two ocelli beyond the middle, and with a broad spatulate tail bearing two spots.

Expansion of the fore wings 4 inches.

Inhabits the islands in the viciuity of Torres Straits. Commander John M. R. Ince.
\end{abstract}

Description.-The markings on the underside of the wings are thus arranged: close to the base of the costa arises a pale streak, which runs about three-fourths of the length of the hind wings, where it is confluent with the extremity of the second pale striga, which is more distinct and extends to the costa of the fore wings; the third striga crosses the middle of the discoidal area of the fore wings, and terminates at the inner side of the discoidal cell of the hind ones; a fourth pale narrow striga crosses the discoidal cell of the fore wings alone. The middle of all the wings is crossed hy a broadish fulvous-brown fascia, with a pale edge on each side, which terminates above the ocellus nearest the tail. A rather broad pale striga and a very narrow submarginal pale line run close to the apical margin of all the wings, preceded in the hind wings by the two ocelli, the innermost being the largest, having a white dot in the ccntre and a slender black circular ontline. The tail is broad, with two black dots edged above with white. The body is fulvous-brown. The under side of the abdomen is furnished with long setæ, and the anal vein of the hind wings has a fascicle of short hairs opposite the extremity of the abdomen : the body and antemnæ are fulvous-brown.

\section{FIGURE 5.}

This outline figure represents the fore wing of Zeuxidia Luxerii, mentioned above, in order to show the very curious arrangement of the veins, whereby it will be seen that the folding of the wing marked* (which iu Amathusia follows the long branch marked + ) is here converted into a fourth branch of the great median vein by means of a distinct twig $\ddagger$ which connects it therewith. 



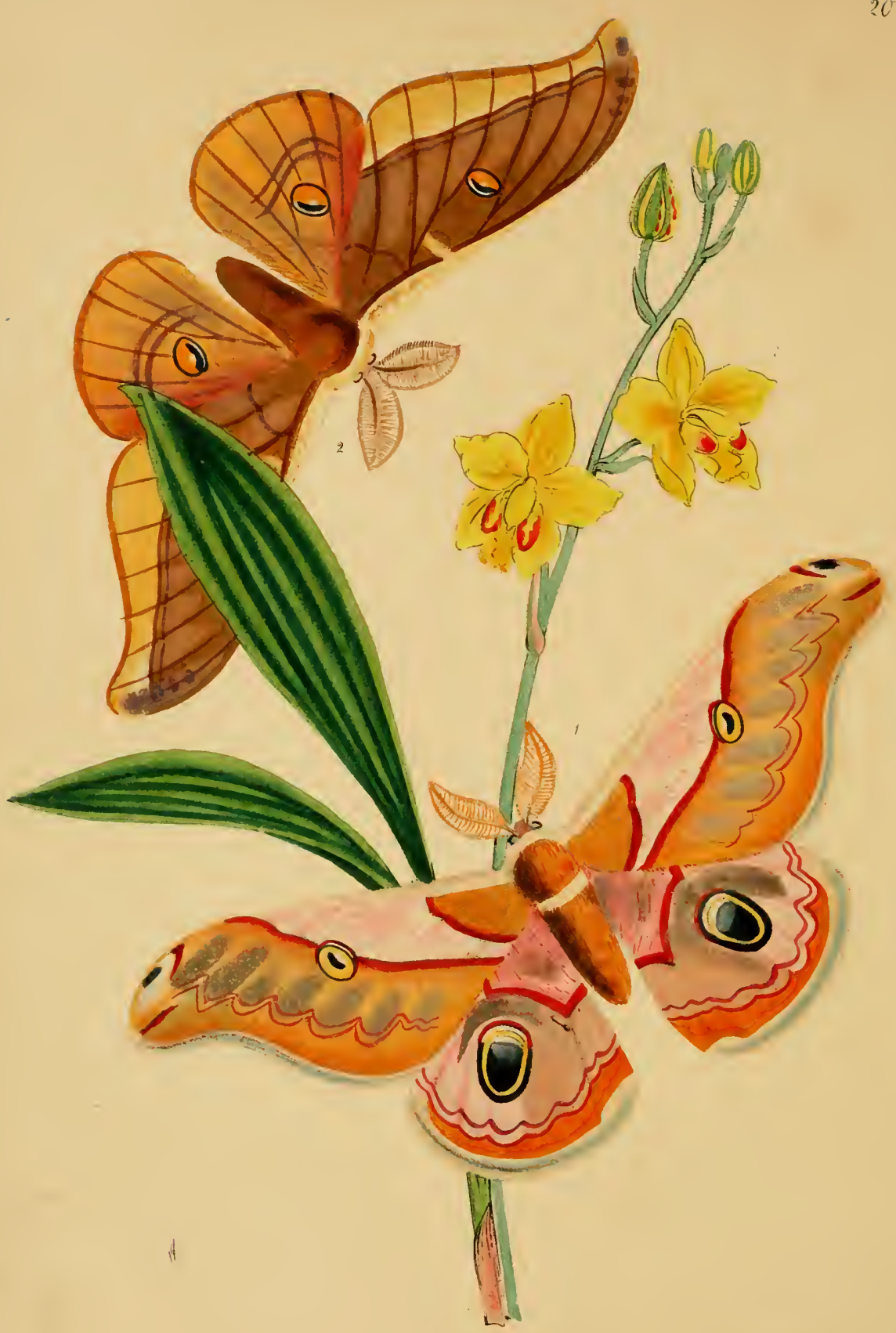





\section{PLATE XX.}

(ORDER-LEPIDOPTERA. \\ FIGURE I.
}

SATURNIA SIMLA, WeSTw.

Observations. - The female of this fine species has the fore wings comparatively larger and less hooked than in the males; the antennæ are much less pectinated, and the ocellus of the hind wings is rounder. Each ocellus bears a very slender vitreous transverse streak. The antennæ are fulvous buff, the front of the thorax is of the same colour as the costa of the fore wings, and the hind part of the thorax is marked with a transverse white stripe which, when the wings are closed, must be continuous with the slender pale inner part of the fascia of the fore wings; the abdomen is of a pale pinkish buff.

I trust that, in consequence of Captain Boys' arrival in England, I shall be enabled, in a subsequent article, to communicate an account of the early states of this insect.

\section{FIGURE 2.}

SATURNiA ASSAMA. Westw.

Saturnia alis omnibus supra saturate fulvo-ferrugineis, costa anticarum albida, omnibus ocello parvo fulvo, antice fusce notatis, strigisque duabus griseis pone medium alarum, margine postico subpallidiori. 
Saturnia with all the wings on the upper side of a darkish fulvous-red, with a buff costa and front margin of the thorax ; each wing is marked in the middle with a small fulvous ocellus being more dusky towards the base, with a very slender white semicircular line and a very minute vitreous dot. At some distance beyoud the ocelli are two parallel ashy or rather slaty-grey strigæ, almost straight in the fore wings, but much curved in the hind ones, extending from the apical angle of the fore ones to the anal margin of the hind ones; the space beyond these strigx is of a pale colour. Towards the base of the wings is a very obscure transverse strigr, and the space between the outer margin and the ocellus of the hind wings is of a richer purplish red. The antenne are dark fulvous-brown, and the head and body are red brown. The colouring on the underside of the rvings is nearly similar, but the strigæ are almost obliterated.

Expansion of the fore wings rather more than 5 i inches.

Inhabits Assam. Communicated by Lieutenant Robinson.

The plant represented in this plate is the Spathoglottis Fortuni of Lindley, from Hong Kong; and that figured in Plate XIX. is the Lilium Thomsonianum of Royle, from Mussooree. 



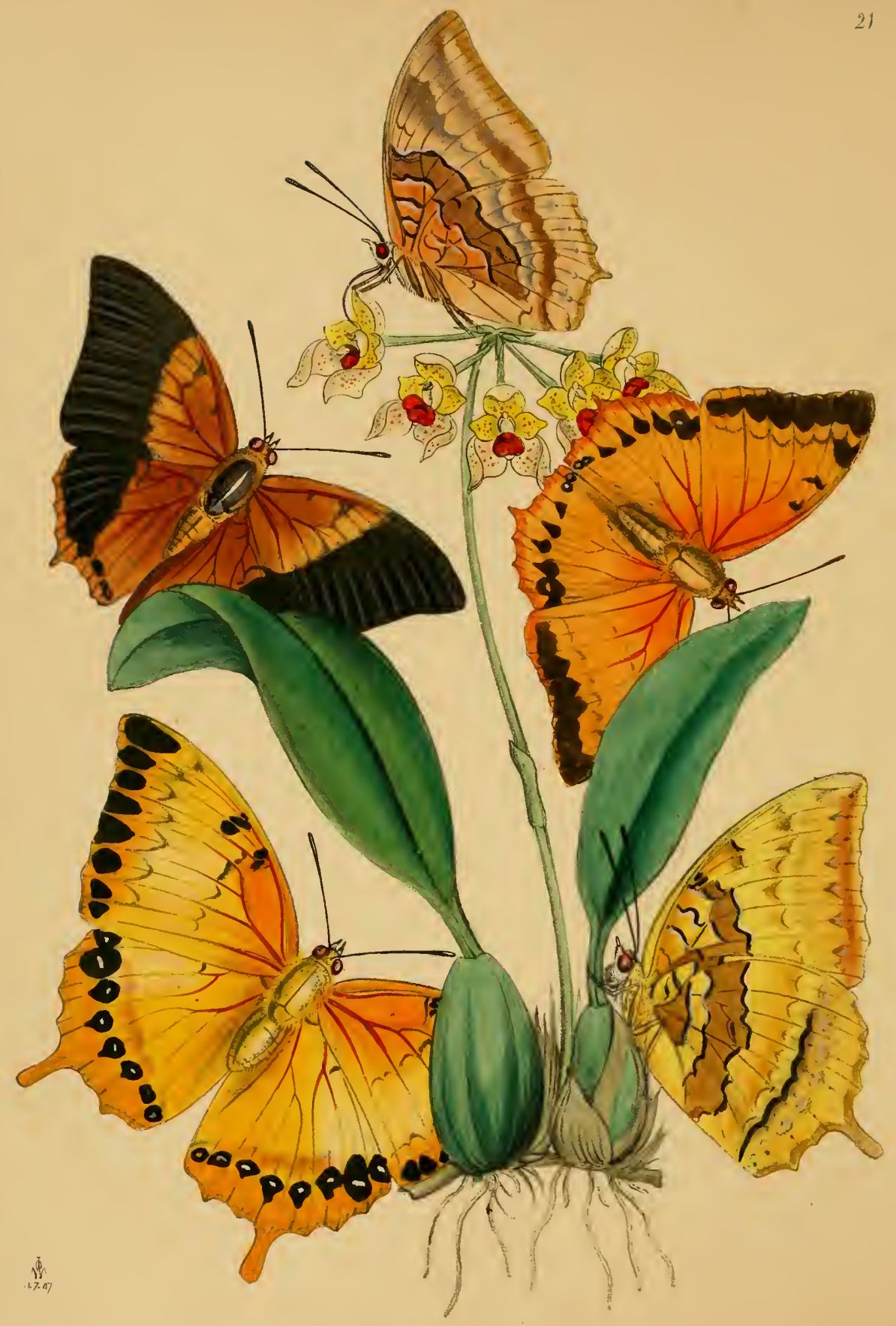





\title{
PLATE XXI.
}

\author{
(ORDER-LEPIDOPTERA. Sectox-Dicray. Family-Nympialide. Leach.)
}

CILARAXES PSAPHON. WEstw. (Middle and upper left hand figures).

Charaxes alis omnibus supra fulvo-ferrugineis, dimidio externo anticarum plagaque maxima externa posticarum nigris; subtus omnibus lrunneo, lutescenti, et griseo variegatis, lineisque variis nigris, fascias irregulares, in medio basali alarum, formantibus, albo marginatis.

Charaxes with all the wings on the upper side of a very rich dark fulvous red colour, the outer half of the fore wings and a very large patel on the hind wings, oecupying nearly the outer half, of a litack eolour, the under side of all the wings varied with glossy brunncous, dull buff and greyish tints, the basal half of the wings varied with irregular slender black liues forming irregular fascix, more or less edged with white.

Expansion of the fore wings 4 inches.

Inlabits Ceylon. In the Collection of R. Templeton, Esq.

Description.-The onter margin of the fore wings scarcely appears to be waved, as in the following species; and the transverse vein, which closes the discoidal cell, is marked with black. The hind wings have a narrow black lnnule preceding the great black patch, which latter is followed by two blaek spots next the anal angle, which is moreover marked with two small black and white dots. The markings on the underside very nearly resemble those of Charaxes Bermardus; but the colours are darker and more varied, with a purplish brown tinge. The hind wings have a submarginal row of black dots preceded by white ones. The only specimen I hare hitherto seen of this species was lately sent from Ceylon by R. Templeton, Esq., R.A. It is unfurtumately not in the finest state of preservation.

\section{CHARAXES MARMAX. WESTw.}

Male, upper right hand figure. Female, two lower figures.

\begin{abstract}
Charaxes alis omnibus supra læte fulvis (medio in foemina pallidioribus), maculis nigris subeostalibus, striga undata fusca ante apicem, maculisque nigris marginalibus confluentibus, posticis serie submarginali maeularum nigrarum albo plus minusve maculatis ; ommbus subtus flavo-fulvis, fulvo et grisescente variegatis, lineisque variis nigris abbreviatis in dimidio basali alarum.

Charaxes with all the wings above of $a$ rich orange colour, the middle portion in the females being paler than the rest of the wing, with some small black spots forming two patehes near the costa in the middle of the fore wings (connected in the female with a row of dusky lunules); beyond the middle of the fore wings is a row of dusky lunules followed by a marginal series of large black confluent spots; the hind wings are marked beyond the middle with an irregular row of black spots mostly wedge-shaped, each bearing in the female a small white spot ; the underside of the wings is of a fulvous or yellow buff colour, varied towards the base with darkerimegular fasciæ edged by thin black lines which are also margined with greyish white. The hind wings have a dark grey transver'se faseia beyond the middle, succeeded by a pearly space ou which are white transverse spots followed by ninute black dots; the pearly spots appear of a triangular form on the fore wings towards the outer margin, between which and the middle of the wing is a dark fulvous row of thin lunular streaks.
\end{abstract}

Expansion of the fore wings of the male $3 \frac{1}{2}$ inches; of the females $4 \frac{3}{4}$ inches.

Inhabits Assam. Communicated by Major F. Jenkins. Also inhabits Syllet. In Mus. Saunders.

Observations.-This fine species is rery closely allied to Charaxes Bemardus, Fabr. (Donovan, 
Insects of China, pl. 34, of my edition*). In both sexes of that species, however, the middle of the wings bears a large, very pale, buff or white patch, (which indeed somewhat reappears in the female of the present species); the extremity of the fore wings in Ch. Bernardus is, however, much darker than in this species. Ch. Bernardus may thus be considered as intermediate between Ch. Psaphon and Marmax. The markings of the under side of the wings, in all these species, is very similar although the colouring differs; the difference in the length of the tails of the hind wings in the opposite sexes of this species occurs also in Ch. Bernardus, whilst the tail at the anal angle of these wings is almost obliterated.

Col. Hearsey informs me that he usually took the Indian Ch. Fabius upon wounded apple trees, the butterflies frequenting the wounds to suck up the fluids which were discharged therefrom.

The powers of flight in this genus must be very great; in fact the form and proportion of the wings and the great strength of the wing reins, seem especially to fit the species of this genus for the most powerful flight.

: The plant represented in this plate is Bolbophyllum nmbellatum, from the mountains of India.

* This figure of Donovan is a good copy of Jones' drawing from which Fabricius described the species. Pap. Polyxena, Cramer, pl. 54, fig. A B, is very similar. 


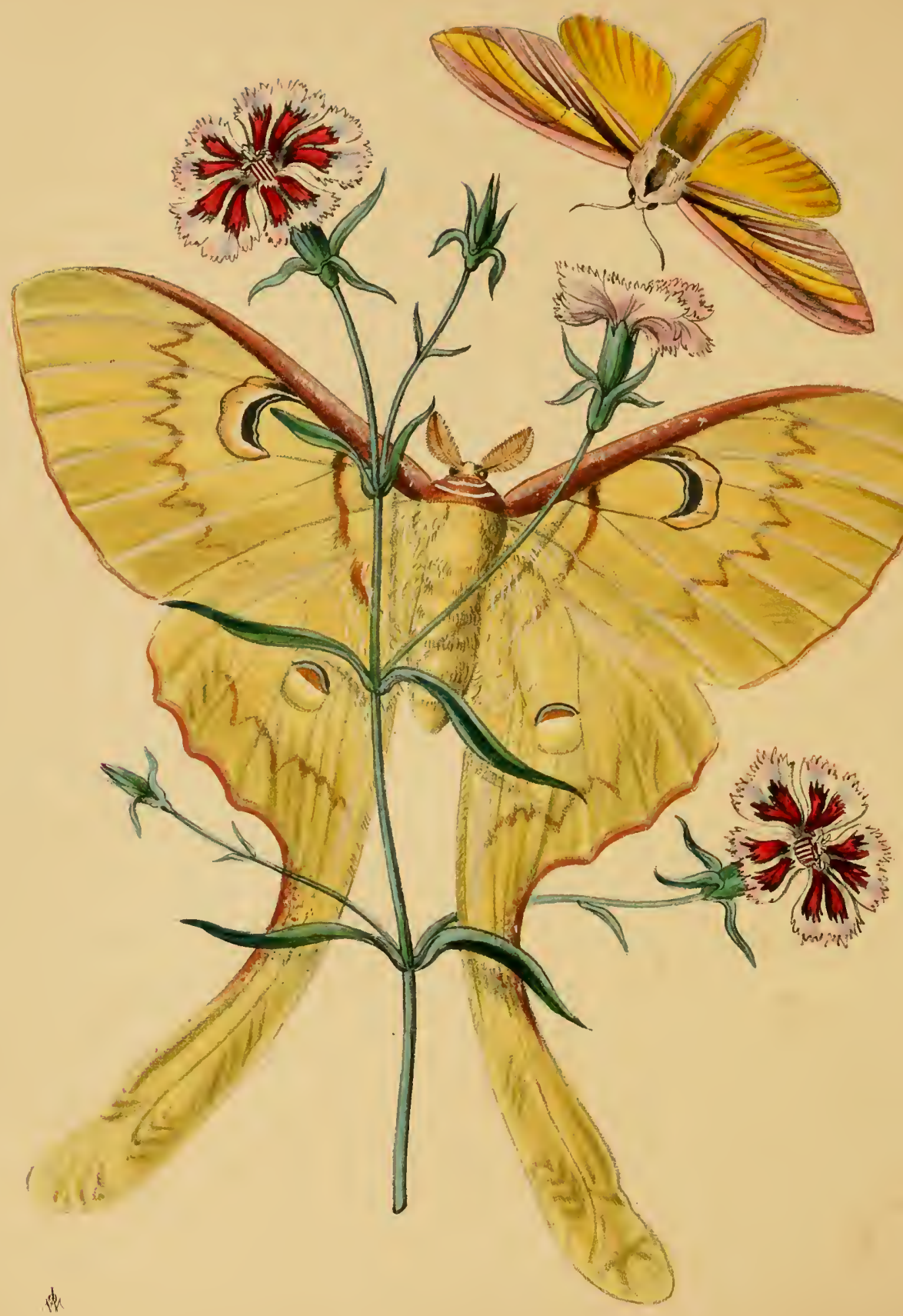





\title{
PLATE XXII.
}

(ORDER-LEPIDOPTERA.
Family-Bosibycid.e, Leacir.)

FIGURE 1 .

ACTIAS MANAS. DoublediY.

(Lower Figure.)

\begin{abstract}
Actias alis omnibus pallide viridi-flavis, marginibus externis rufescentibus, anticis costa ferruginea, eincreo lavata, lunula magna discoidali fascia transversa baseos, alteraque postica indistincta valde undata rufescentibus; posticis longe caudatis acello parvo discoidali, nigro antice eineta, fascia pone medium flexuosa obsoleta rufescente.

Expansion of the fore wings nearly 7 inches ; length of the hind mings and tails $5 \frac{1}{4}$ inches.

Inhabits Silhet. In the Collections of the British Museum, and W. W. Saunders, Esq.

Srxonrue:-Actins Mienas, E. Doubleday, in Annals Nat. Hist., February, 1847, 1. 95.
\end{abstract}

Descriftion.-Anterior wings very broad and rounded, pale grcenish-rellow, the costa, except at the apex, ferruginous, spriukled with cinereous atoms; outer margin rufescent; near the base a transverse narrow band of the same colour, darkest next the costa, and beyond the middle a very indistinct flexuous reddish streak, a large lunule at the end of the cell comncter with the costal ritta, of the same colour with this at its origin, then much paler externally, nearly black internally, marked with a very delicate white line. Posterior wings of the same colour as the anterior, with very long tails, which are wrinkled at the extremity, sprinkled with ferruginous from the base nearly to the middle; the outer margin of the wing, and of the basal half of the tail ferruginous. In the middle of the disc is a small black lunule divided by a white line, from a nearly circular ocellus of a pale fulvous colour; darkest towards the base, between this and the margin, is a very obsolete waved striga.

Below, the anterior wings want the basal striga, the costa is paler, the lunule is replaced by a transverse-orate small fulvous ocellus, and the flexuous band is more distinct, as it also is on the posterior wings, which have the ocellus more distinct. Head and antennæ pale. Thorax greenish-yellow, the front part broadly ferrnginous, sprinkled with cinereous; legs vinous-red, with pale spots. Abdomen pale greenish-yellow.

OBservations. - The accompanying figure of this rery fine insect is copied from a specimen kindly communicated for representation by W. W. Sannders, Esq., F.L.S., which differs in some respects from Mr. Doubleday's description of the species, recently published. It belongs to the genus Actias, separated by Dr. Leach, which has for its types Bombyx Selene and B. Luna; from the former of these species it is distinguished by the much greater elougation of the tails, the differently shaped wings, the large lunate mark on the fore wings, \&c.

This is certainly one of the finest of the recent additions to the list of oriental Lepidoptera; but I am informed that Dr. Boisduval possesses a species of this genus from Madagascar with much longer tails to the hind wings. 
FIGURE 2.

LEUCOPHLEBIA LINEATA. WESTW.

(Upper Figure.)

Leucophlebia alis elongatis integris anticis pallide puniceis, vitta lata mediana longitudinali albida, ramis vente mediænæ albis ; alis posticis fulvis, corpore elongato puniceo-albo, dorso fusco.

Leucophlebia with the wings long and entire, the fore oncs pale pink, having a broad longitudinal stripe of yellowish buff down the middle (narrowest towards the base), with the branches of the median vein white ; hind wings dark fulvous ; body long, pinkish white ; brown in the middle of the back. Expansion of the fore wings 2-3s inches.

Inhahits Central India, Assam, de. In the Collections of the British Museum, Col. Hearsey, Capt. Boys and Westwood. (Communicated by Major Jenkins.)

Onsenvations.-This beautiful insect appears to possess the characters of a distinct genus, in the classification of the cxotic Nocturnal Heterocerous Lepidoptera; its elongated body and wings give it an analogy with some of the Sphingidre, as well as to some of the prominent motlis, especially to Leiocampa Dictœa; the structure of the antennæ of the male is rery similar to that of the genus Smerinthus as well as Hammatophora bucephala, but they are more robust towards the tip, in the species before us, than in the latter insect. The reins of the fore wings are nearly arranged as in Leiocampa Dictoa, with the exception that the small branch emitted from the subcostal rein near the tip of the ming in the last named species, and in a great number of the allied British genera, is not perceired in the species before ns, in which respect it also agrees with Smerinthus; the antennæ of the female are rey short and simple, and the spiral tongue is rather elongated.

The flower represented in the plate is the chinesc pink, Dianthus chinensis. 



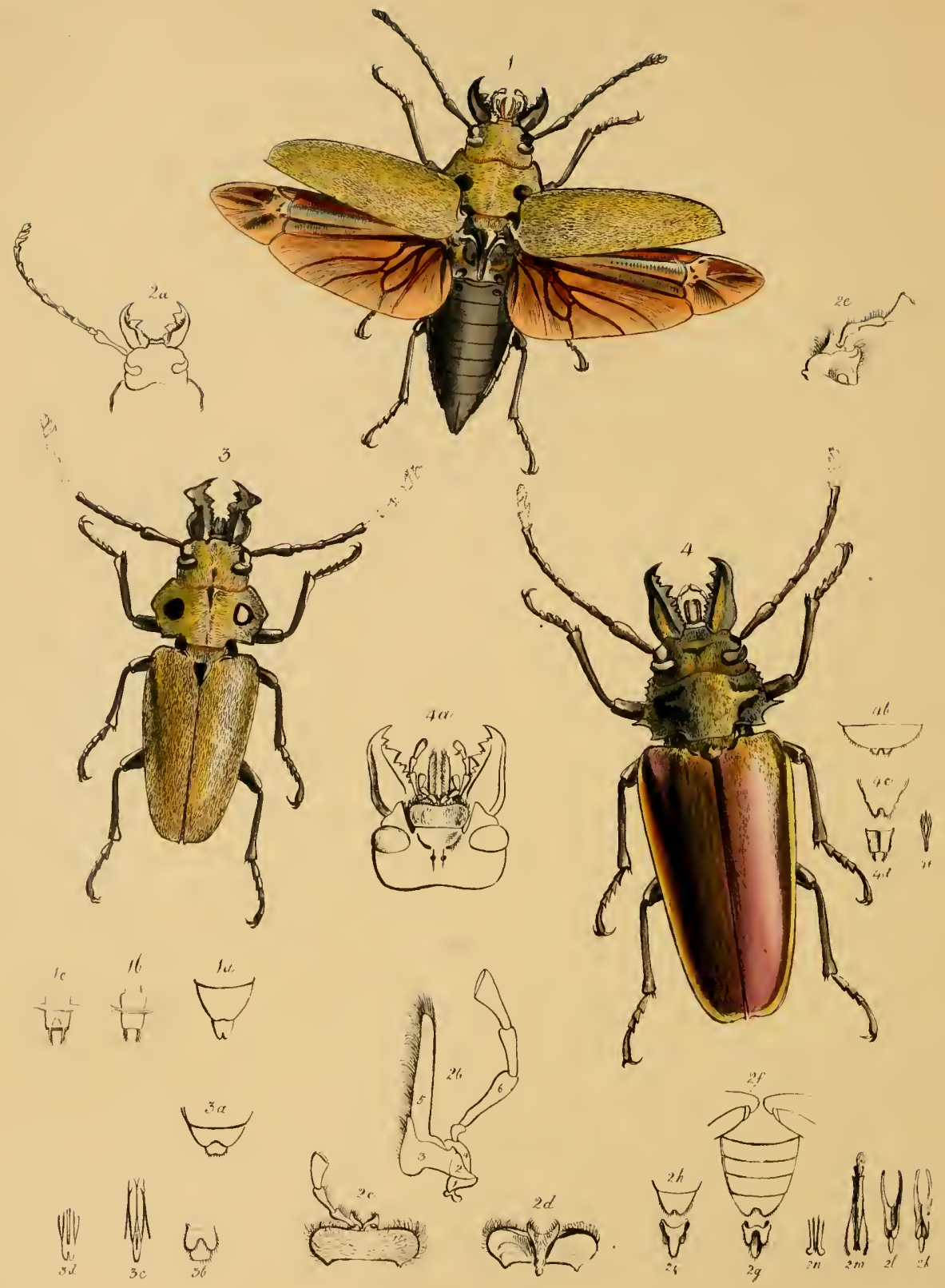






\section{PLA'TE XXIII.}

(ORDER-COLEOPTERA. Section-Longlconses. Famll-Trictenotomide. Westw.)

Tre first notice of the type of this very anomalous group of insects appeared in a note appended to a paper of nine in the 1stl number of the "Zoological Journal," (published in 1530,) in which I regarded it as a connceting link between the Prionidic and Lucanida, agreeing with the former in its general appcarance, short trigonate advanced mandibles and moderately long antenux, whilst in the internally produced structure of the threc terminal joints of the autenna it agrees with Lueanus; observing, morcorer, that the joints of the tarsi are eylindrie (as in the latter), but the insect is hetcromerous!

Shortly afterwards a figure of the type Trietenotoma Childrenii was published from a drawing of mine in the plates to Griffith's edition of the "Animal Kingdom," and M. Guerin Ménéville also gave a figure of it in his "Magasin de Zoologie," pl. 35, with a notice by M. Dupont in which the position of the genus was considered to be "en tête des Longicornes, famille on, par tous ses rapports il entre tout naturellement."

During the period which has sinee elapsed no further attempt has been made to investigate the affinities of the genus by an examination of its structural characters. Having, however, recently received a specimen of $\mathrm{T}$. Childrenii from Assam by the kindness of Major Jenkins, and two other new and rery distinct species haring also been recently received in this country, I have submitted the whole to a careful investigation, the result of which is before the student in the accompanying plate.

From the considerations derived from the structure not only of the mouth organs but also the position of the wing veins and numerical arrangement of the abdominal segments, I have no longer any hesitation in referring the insect to the section Longicornes, notwithstanding the internally produced terminal joints of the antennæ (which is too trivial a character to be considered of high importance in limiting the groups), the beteromerous tarsi, and the structure of the organs of generation. Moreover, its nearest affinities appear to be the Prionidæ, especially in the porrceted head and mandibles, moderately short antennæ, slightly emarginate eyes, and wing reins. From these, howerer, it differs in several respects, so that I have considered it more natural to regard it as the type of a distinct family, which may be thus characterised.

\section{TRICTENOTONID质. WESTW.}

Head horizontal ; eyes transrerse, slightly emarginate behind the base of the antennæ ; labrum short, transrerse; mandibles porrected, nearly alike in both sexes. Maxillae with the inner lobe scarcely. produeed, outer lobe long, narrow, and hairy; mentum broad, with the sides elevated; labium short, bipartite; antenna moderately long; those of the males rather more elongated; three terminal joints internally serrated. Pronotum with the hind margin lobed in the middle ; wings folded at about threefourths of their length from the base; abdomen with seven dorsal and fire rentral segments; the terminal dorsal segment in the male notched; the terminal ventral segment in the same sex more dceply 
notched; the last dorsal segment of the female elongate-conic and notched; the last ventral segment in the same sex cntire; ventral surface of the sheath of the male organs deeply notched; the latter furnished with two long slender horny filaments; sheath of the ovipositor of the female flattened and furnished with two slender hairy filaments; legs moderately long; all the tibiæ entire along the external margin, and with two minute apical spurs; tarsi sub-cylindric, heteromerous, the underside of each juint elothed with a short velvety pad; body more or less clothed with a delicate pubescence.

The family consists at present of the single genus Trictenoтona, of which I liave now the pleasure to describe three species.

FIGURES 1 \& 2.-Species 1. TRICTENOTOMA CHILDRENiI. G. R. Gray in Griff. An, K. pl. 5 \& 5*. $\delta$.

Trictenotoma nigra, supra undique griseo-luteo pubeseens, mandibulis (in utroque sexu) subfalcatis, antennis pedibus maculisque duabus elevatis pronoti nigris hujus lateribus sub-angulatis, scutello triangulari.

Trictenotoma black, covered on the upper surface with luteous-grey pubescence, the mandibles (in both sexes) subfalcate, antennx, legs, and two elevated spots on the pronotum, black; the sides of the latter somewhat angulated; and the scutellum triangular.

Length of the insect $1 \frac{1}{4}$ to $2 \frac{1}{4}$ inches.

Iuhabits various parts of India. In the Collections of the British Museum, Zoological Society, Hope, Parry, Westwood, \&c.

Figure 1. The female of the natural size; la, the last ventral segment of the abdomen with the last dorsal segment extending beyond its extremity; 1 b, 1c, sheath of the ovipositor.

Figure $2 \mathrm{a}$, head of the male; $2 \mathrm{~b}$, maxilla ( 1 cardo, 2 stipes, 3 mando, 4 squama palpigera, 5 galea, 6 palpus.) 2c, $2 \mathrm{~d}, 2 \mathrm{e}$, instrumenta labialia in different positions; $2 \mathrm{f}$ under-side of abdomen of this sex; $2 \mathrm{~g}$, under-side of sheath; $2 \mathrm{~h}$, last dorsal segment of abdomen ; 2i, upper side of sheath ; $2 \mathrm{k}, 2 \mathrm{l}$, inner sheath; $2 \mathrm{~m}$, male organ; $2 \mathrm{n}$, apex of ditto.

\section{FIGURE 3.-SPECIES 2. TRICTENOTOMA TEMPLETONII. Westw. $\delta$}

\footnotetext{
Trietenotoma nigra supra luteo-albido pubescens, mandibulis maris extus valde sinuatis dente magno subapicali erecto armatis, antennis pedibus maculisque duabus elevatis pronoti nigris liujus lateribus angulatis, scutello triangulari.

Trictenotoma black, above clotlied with a luteous-buff pubeseence, the mandibles of the male outwardly much sinuated, and armed near the apex with a large npright tooth; the antenne, legs, and two elevated spots on the prowotum shining black, the sides of the latter angulated and the scutellum triangular.

Length of the insect nearly $2 \frac{1}{2}$ inches.

Inhabits the island of Ceylon. In the Collection of R. Templeton, Esq.
}

Flgure 3. The male of the natural size; $3 \mathrm{a}$, the last rentral segment of the abdomen, showing the extremity of the last dorsal segment, which is scarcely emarginate; $3 \mathrm{~b}$, the under-side of the sheath ; 3c, male organ; $3 \mathrm{~d}$, apex of ditto.

FIGURE 4.-Species 3. TRICTENotona ANEA. Parry. MSS. $q$

Trietenotoma nigra subnitida; elytris æneis vel cupreis pubescentia tenuiori albida induta, mandibulis extus subsinuatis, pronoto utrunque subserrato et pone medium spina acuta armato, disco utrinque tuberculo transverso subelevato, scutello brevi.

Trictenotoma black, somewhat glossy, the elytra brassy or coppery, the upper surface more shightly elothed with a buff pubescence, the mandibles outwardly subserrated, the pronotum slightly serrated at the sides in front and with a sharp spine on each side beyond the middle, the disc with a slightly elevated transvere tubercle on each side, and the scutellum sliort.

Length of the iusect 3 iuches.

Inlabits the Himalayas. In the Collections of Captain Parry, Dr. Benson, and T. V. Wollaston, Esq.

Figure 4. The female of the natural size; $4 \mathrm{a}$, the under-side of the head; $4 \mathrm{~b}$, the last ventral segment, showing the extremity of the last dorsal one; $4 \mathrm{e}$, the last dorsal segment; $4 \mathrm{~d}$, sheath of ovipositor; 4. e, the ovipositor. 


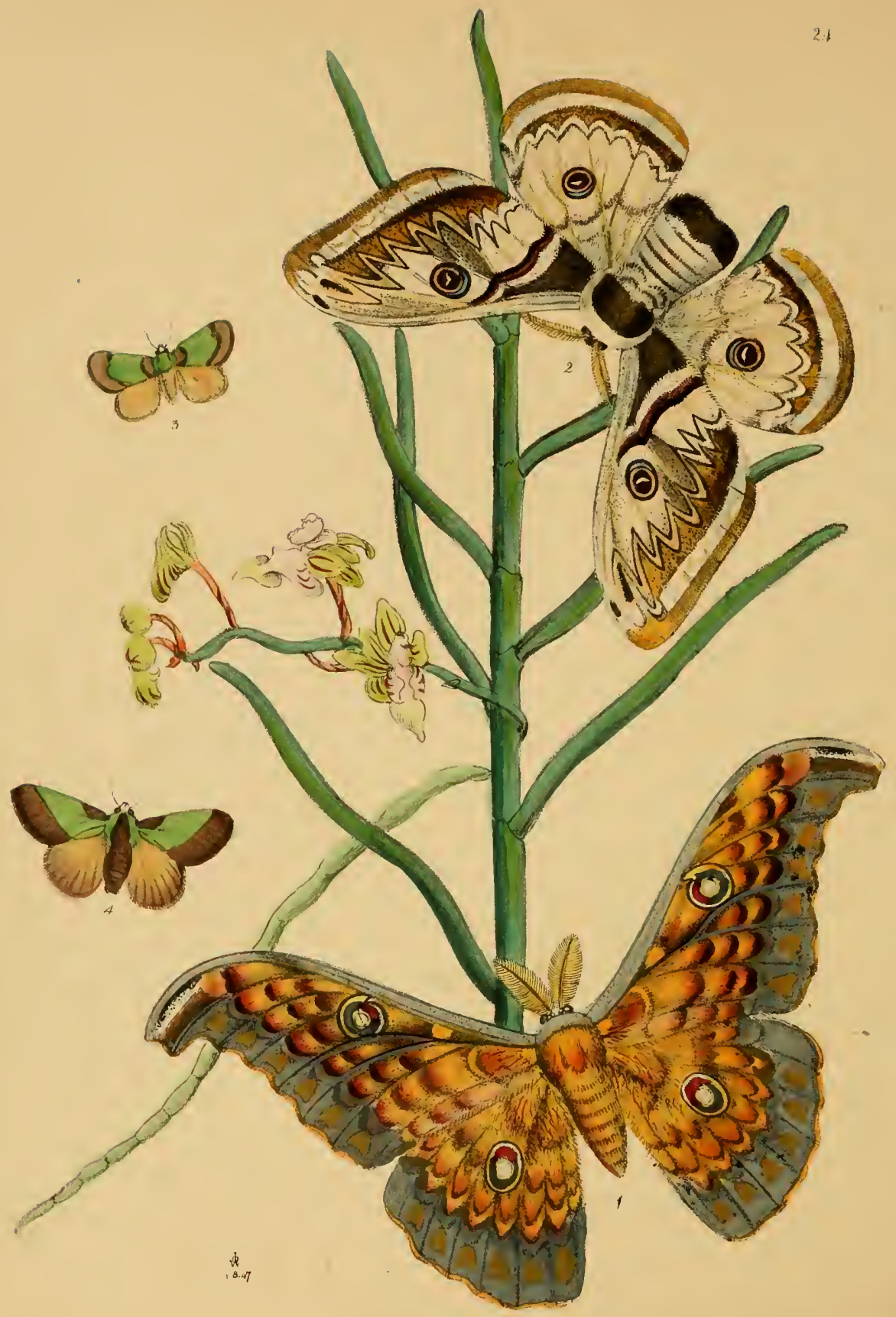






\title{
PLATE XXIV.
}

(ORDER-LEPIDOPTERA.

\section{Sectiox-Nocturna. \\ Family-Boubrcid.e. Leachi.) \\ FIGURE I.}

SATURNiA LARISSA. WESTw.

\begin{abstract}
Saturnia alis supra fulvis disco anticarum in medio saturariori, strigis tribus griseo-brunneis valde undatis singulaque ocello griseo, antice rufo-brunneo, nedio vitreo oruata, costa anticarum grisea, apicibusque luteo-cinereis, corpore fulvo-rufescenti thorace antice griseo.

Saturnia with the upper surface of the wings fulvous, the middle of the dise of the anterior pair darker, and traversed by three very waved greyish-purple-l)rows streaks, each wing being marked with a greyish ocellus, which is anteriorly brownish-red, and in the middle glassy ; the costa of the fore wings gray, and the outer margins broadly luteous-ashy; the body fulrous red, with the front of the thorax grey.

Expansion of the fore wings $5_{\frac{1}{2}}^{1}$ inches.

Inlabits the Island of Java. In the Collection of M. Dalen.
\end{abstract}

OвSERVATIONs. - I am indelsted for drawings of the two beautiful species of Saturnia, represented in the present Plate, to M. Dalen, of Rotterdam, the possessor of a fine Collection of exotic Lepidoptera, the drawings themselves having been executed by Colonel Ver Huell, an excellent Lepidopterist of Holland.

The present species is remarkable for the very sickle-shaped fore wings, the middle of which is trarersed by three darker very wared strigæ, varying in inteusity of colour, being darkest and rich purplish-brown in the ncighbourhood of the ocellus, which are circular in the fore wings, and connected with the costa by a short fulvous twig, edged with black, which extends round the outer half of the ocellus, within which is a fulvous line, which is replaced towards the base by a very slender white one; the centre is occupied by a ritreous space, edged with a fine yellowish line, traversed also by a slender one of the same colour; towards the base of the wing is also a pale semicircular streak, and bejond this a pale patch next the costa; towards the apex of the wing is a purplish-black streak, much irrorated with white scales; the outer margin of the wing is broadly ashy clay-coloured, the fringe itself fulvous. The hind wings are similarly coloured, but the waved streaks are paler, and between the ocellus (which is oral, but coloured as in the fore wings) and the base of the wing is a very obscure dusky fascia; the thorax and base of the wings are much clothed with reddish hairs, the abdominal margin of the hind wings with grey ones. The spccimen is a male.

\section{FIGURE 2.}

\section{SATURNIA PYRETORUM. Boisderal. MSS.}

Saturnia alis rotundatis albo-lacteis singula ocello nictitanti lunula tenui vitrea inclusa ornata; strigis duabns posticis valde dentatis fasciâ latâ sub-apicali fusca comnexis, limboque postico fusco ; anticis basi fasciaque fuscis.

Saturnin with the wings ronnded and milky-whitc, each with a moderate-sized oval black ocellus, having a slender oval fulrous line surmounted by a slender pale-lblue lunule, and with a curved vitreous central streak ; beyond the 
middle of the wings are two strougly dentated slender dark strigæe resting upon a broad brownish subapical bar; the outer margin of the wing also clay-brown; the base of the fore wings and an adjacent striga, brown.

Expansion of the fore wings 4 inches.

Inhabits China. In the Collection of M. Dalen.

DESCRIPTION.-The front of the thorax and costa of the fore wings are whitish, the latter greyish towards the tips, which bear two small oblong black patches, irrorated with white scales, followed by two dark-red lunules. The base of the wing is brown, with luteous scales, followed at a short distance by a dark-brown fascia, purplish on the inside. Behind the ocellus of the fore wings is a somewhat triangnlar patch of grey and luteous scales; the hind wings are traversed by a very pale streak.between the base and the ocellus. The head and hind part of the thorax, as well as a large tuft at the tail, are dark-browu, and the antenuæ are luteous buff. The specimen deliueated is a female.

This species is allied to S. Pavonia.

\section{FIGURE 3.}

LIMACODES HILARIS. WESTW.

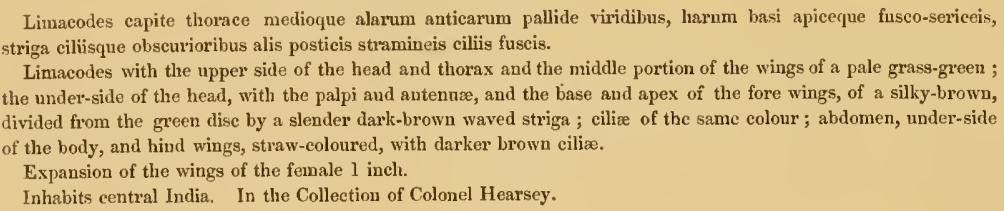

\section{FIGURE 4.}

LIMACODES GRACIOSA. WESTW.

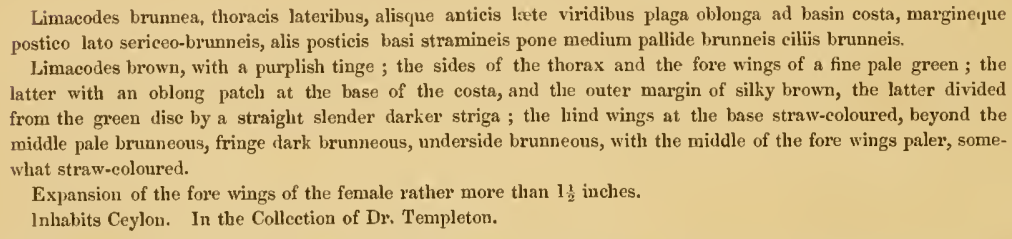

Colonel Hearsey has brought home a male specimen of this genus from Central India, which I consider as the male of L. graciosa, which differs only from the female in having the upper side of the head and thorax entirely pale green, aud the hind wings pale buff, with the outer margin rather darker.

Dr. Templeton has also sent another species from Ceylon, closely allied to the two preceding, which may be thus characterised.

Limacodes lata, Westw., capite et prothorace supra fasciaque tenui sub-mediana alarum anticarum parum uudata viridibns, harum basi apiceque late brunneis, macula parva alba rersus basin alarum, alis posticis basi stramineis apiceque obscuriori. Exp. alar. antic. 1 unc.

The plant represented in this plate is the Vanda teretifolia of Lindley, from China. 
a

$-$ 


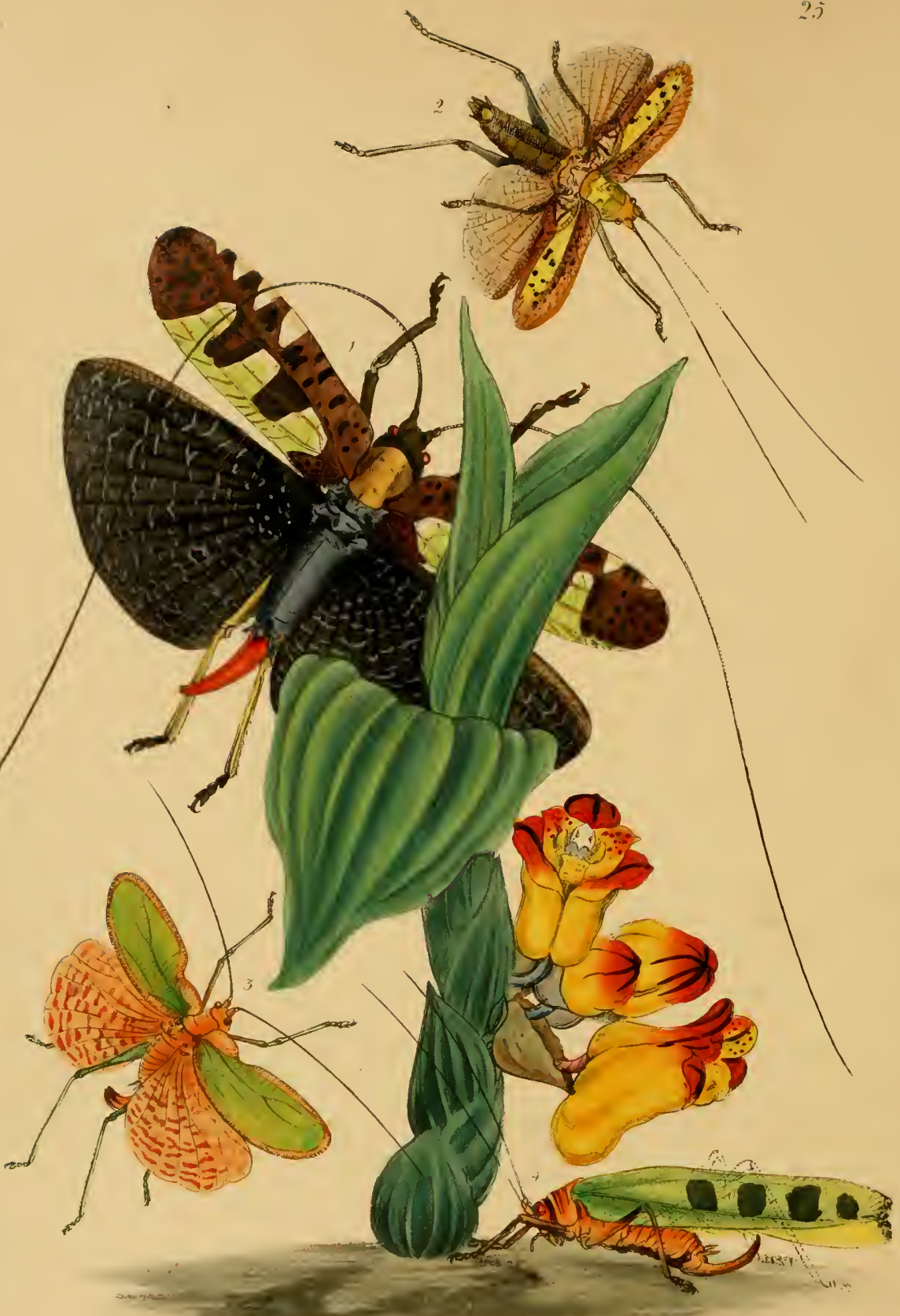





\title{
PLATE XXV.
}

\author{
(ORDER-0rtioptera. Section-Saltatoli.. Famlly-Gryllid.e, Leach. Locustarl.e Latr.)
}

FIGURE 1.

ACANTIIODIS IMPERLALIS White, (A.s. NAt. Hist. Vol. xviii., pl. 1, fig. 1.)

\begin{abstract}
Acanthodis nigricans, pronoto viridi-flaveseente ; tegminibus casta brumnea uigro alboque maculata, parte postica nigricanti maculis tribus magnis (margine interno connexis) viridibus; alis nigris venis transversis viridi-albis, pedibus anticis nigricantibus, posticis viridibus.

Acanthodis with the body black, the pronotum yellowish green, the costa of the tegmina rich brunneous with black and white spots, the hind part blackish with three large beautiful green spots which are united together on the inner margin ; the wings black with the transverse veins of greenish white, the fore legs blackish, the lind ones greenish. Expansion of the wings $4 \frac{1}{2}$ inches. Length, iucluding the ovipesiter, $2 \frac{3}{4}$ inches. Length of the antennæ 6 inches. Inhabits Assam and Sylhet. Communicated by Col. Jenkins, E. Doubleday, and W. W. Saunders, Esqrs.
\end{abstract}

Description.- Head yellow in front, the rest brown; body shaded below with light brown; pronotum nearly smooth, yellowish green with two transrerse impressions; tegmina soncwhat bulging at the base, brown with black marks, and with from three to six small yellowish-green sub-triangular spots on the costa; the greater part of the inner margin of a most beautiful green, with three large patches generally reaching the large middle rein; the outside edges of the green parts sometimes sliaded to white; wings glossy black, marked with many short pale greenish-white transverse veins, with sereral faint whitish spots on the costa; the fore legs, middle tibiæ and all the tarsi blackishbrown, remainder of the legs green or yellowish-brown; hind legs not spinose and rather short; oripositor long, sabre-shaped, chestnnt-brown, darker at the tip. All the sterual plates simple, transrerse, and buff-coloured. Anal plate of the male buff-coloured, large, somewhat conical, terminated by tro points. The crepitaculum of the fore wings of the male, of moderate size, black, reticulated with fulvous reins.

This is one of the most beantiful species of the family hitherto discovered, the fine contrast of its colours giving it a peculiarly rich appearance.

\section{FIGURE 2.}

ACANTHOdis Donovant. Dovov. (Nat. Repos, 2, pl.69.)

Acanthodis fusea pronoto fulvo margine pastico fuseo, tuberculis duobus mediis, fasciaque media abdominis pallida, tegminibus rufescentibus maeulis numerosis nigris liturisque variis irregularibus plus minusve eonfluentibus $H$ wa viridibus medium tegminum oeeupantibus, alis pallidis costa renisque transversis pallide fuscescentibus.

Acanthodis brown, with the pronotum fulvous, hind margin brown and with two tubercles on the disc, the middle of the abdomen with a pale fascia, the tegmina reddish, with numerous black spots and various irregular patehes of greenish-yellow, more or less confluent, along the middle of the tegmina, wings pale, with , the costa and transverse reins pale brawn.

Expansion of the wings of the male $2 \frac{1}{8}$ inches; of the female $3 \frac{3}{4}$ inches.

Inhabits the East Indies. In Mus. Hope.

Observatioss. - Donoran haring giren a representation (somewhat indeed exaggerated) of the female, the opposite sex of this rely rare species is here delineated. In this sex the wings are considerably 
more abbreviated than in the preceding species; they are more acute at the tips than in the female, and the crepitaculum is of large size. In the only male which I have seen, the pale spots on the tegmina are entirely confluent, but in the female figured by Donovan, they form three large pale patches almost as in A. imperialis, except that the hind margin is reddish-brom ; the anal plate of the male is conical and bifid at the tip, with two short filamentous processes on the upper side of the extremity of the body. The clypens and the base of the upper lip are marked with brown in both sexes, and the sternal plates are broad, simple, and buff-coloured.

\title{
FIGURE 3.
}

PHYLLOPTERA SANGUINOLENTA. WESTW.

\begin{abstract}
Phylloptera luteo-vel fulro-riridis, tegminibus latis viridibus margine postico tenui fulvo, nigro irrorato, costa versus basiu emarginata ; alis tegminibus haud longioribus, fulvis, opacis, venis transversis puniceis ; oriductu brevi lato recurvo serrulato apice obscurioris tibiis posticis vix spinosis.

Phyllopters with the body of a luteous or fulrous colour tinged with green, the tegmina broad, green, the posterior or dorsal slender margin fulvous with minute black dots, the costa near the base with a notch, the bind wings not longer than the tegmina, of a fulvous colour varied with transverse purplish red bars along the transwerse veins, the oripositor short, broad, recurved and subserrated, the tip darker coloured, the hind tibiæ scarcely spinose.

Expansion of the wings of the male nearly $] \frac{1}{2}$ inches, of the female $2 \frac{1}{4}$ inches.

Inhabits Sumatra. Sir S. Raffles. In the Iuseum of the Zoological Society of London.
\end{abstract}

OBSERvatioxs.- The face is convex and perpendicular; between the bases of the anteunæ is a rery small rounded tubercle; the pronotum is broader than long, not distinctly carinated at the sides; the tibix are slender, greenish, with slender black lines; the tegmina are dilated and rounded on the posterior margin, not glossy, of a grass-green colour, and when seen throngh a lens, are found to be thickly irrorated with rery minute red spots; the veins (except the few principal longitudinal ones) are scarecly discernible by the naked eye. The crepitaculum of the male is not strongly veined; its posterior margin, especially in the right wing corer, is slightly angulated. The terminal joint of the palpi is dilated at the tip and obliquely truncate.

\section{FIGURE 4.}

PHYLLOPTERA \&-MACULATA. WESTW.

\footnotetext{
Phylloptera viridi-fulva, fusco variegata, tegminilus corpore fere duplo longioribus viridibus, singulo maculis 4 nugnis fuscis; alis tegminibus parum longioribus, favescenti-hyalinis, oviductu longiori recurvo rugoso.

Phylloptera of a grecnish-fulvous colour, varied with brown, the tegmina nearly twice the length of the body, narrow, green; each with four large dark-brown spots; the wings rather longer than the tegmina, yellowish liyaline, the apical exposed portion greenish; the ovipositor is longer and narrower than in the preceding species, brown and rugose.

Expansion of the wings $4 \frac{3}{4}$ inches.

Inhabits Sumatra. Sir S. Raffles. In the Collection of the Zoological Society of London.
}

OBservations.- I have only seen a single specimen of the female of this pretty species, which wants the hind feet. 


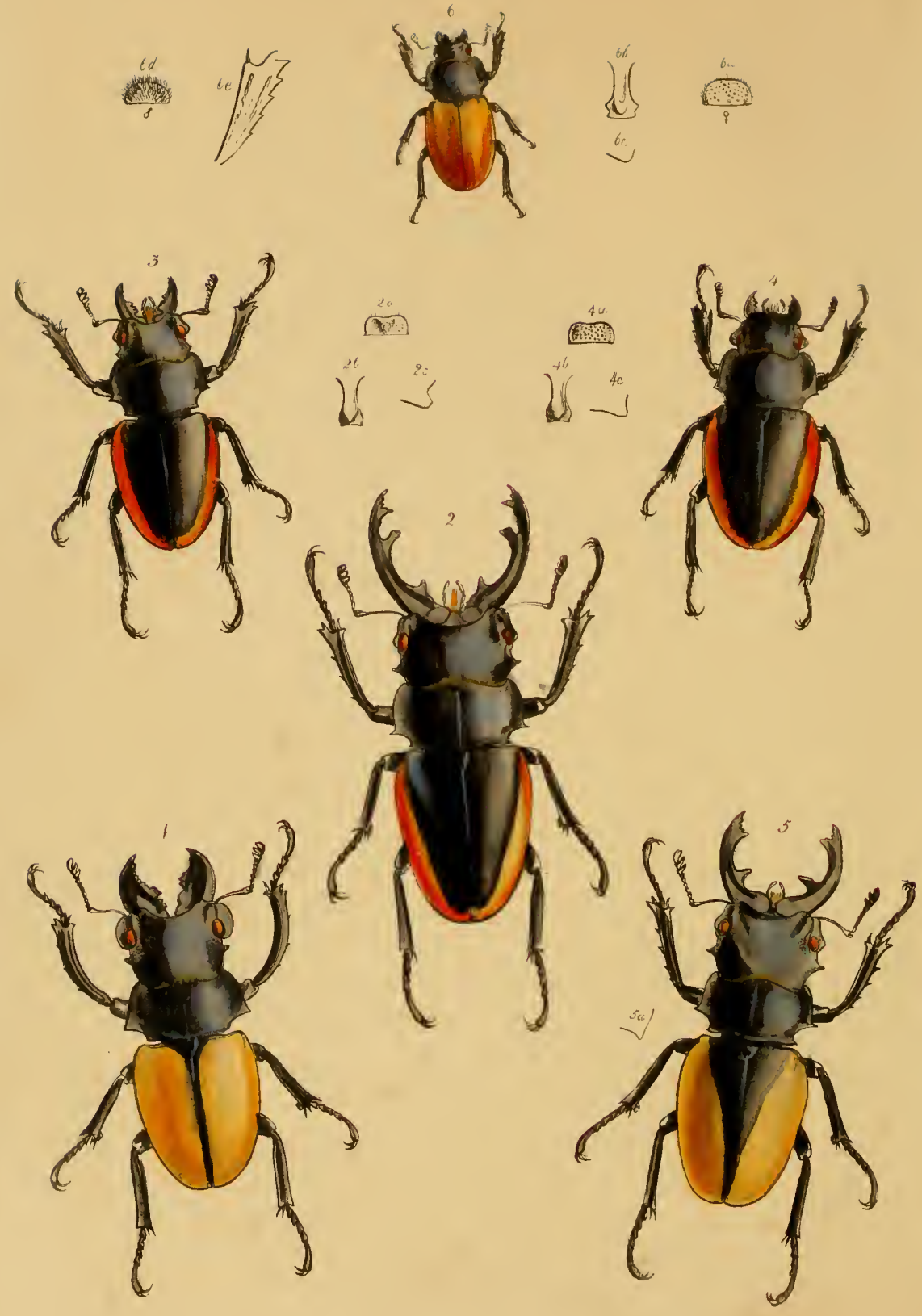



\title{
PLATE XXVI. \\ CORDER-COLEOPTERA. \\ Dirision-Pextamera. \\ Fanily-Lucanid.e. Leacu.)
}

Mecu confusion having been introdueed into the nomenclature of those oriental species of Stag. beetles which have the luteous or fulvous clytra, more or less suffused with black; I have thought it might be serviceable to make them the subject of a separate article. The sub-genus Odontolabis, Hope, comprises those specics of Lucanus which have the cyes entirely divided by the canthus, the fore tibi:e in the males externally armed with small spines; the intermeliate and posterior tibixe in both sexes externally unarmed, the body not metallic-coloured, and the club of the antenne 3-partite. All the insects represented in the accompanying plate cuter into the group thus characterised.

\section{FIGURE 1.}

\section{LUCANES (ODUNTOLABIS) BICOLOR, OLivier. (ENrom. 1, pl. 5, F. 20.)}

\begin{abstract}
Lueanus niger, elytris pallicle testaceis sutura tenui nigra; mandibulis latis capite panum brevioribus areuatis denticulatis ; oculorum septo magno rotundato, capite utrinque pone oculos spina parva armato, fronte antice laaul clevato, prothoracis lateribus acute augulatis, angulis posticis emarginatis, tibiis anticis curvatis supra suleatis, extus spinis duabus minutis amatis.

Lucanns black, with the elytra pale testaceous, the scutellum and suture slenderly black; the manlibles broad, rather shorter than the head, curved and denticulated ; the septum of the eyes large and rounded ; the head, behind the eyes, is armed on each side with a small spine, the front of the head is not elevated, the prothorax has the siles acutely angulated, the posterior angles are emarginated, and the fore tibia curved, deeply suleated, and externally armed witl two very minute spines in addition to the bifid apex. (Male.)

Length of the insect without the mandibles nearly 2 inches.
\end{abstract}

Observations.-My figure of this species is copied from a specimen in the British Museum, from Nepaul, presented by Bryan Hodgson, Esq., which precisely corresponds with Olivicr's fignre and with a third specimen in the Banksian Cabinet at the Linnean Society. The female is unknown. In addition to the characters given above, it may be notieed that the mandibles are rery rugose on the underside, especially at the sides; the head is rugose behind the eyes on the upperside; the middle tibire hare a small dilatation on the inside at the tip; the mentum is broader, and the space intervening between the coxæ of the fore legs is considerably broader than in the mate of the following species. M. Guerin Ménéville notes that MI. Delessert bronght a specimen completely agreeing with Olivier's figure from the coast of Malay.

FIGURES $2,3,4,5$.

LUCANUS (ODONTOLABIS) GAZELLA, FabriciUs. (Maxt. INs. 1, p. 1.)

Orservatroxs. - The typical specimen of this species, described by Fabricins and figured by Olivier, Ent. 1, pl. 4, fig. 13, from the Banksian Cabinet, is now in the possession of the Limmean Society, and is a native of Siam. This spccimen is a female, and differs only from the insect represented in the accompanying plate (fig. ${ }^{4}$ ), and from M. Guérin's figure of his Lucanus Delessertii (Sour. Voy. Deless. Ins. pl. 12, f. 3), in having the black colour precisely occupying half of each elytron; 
being thus intermediate between these two specimens. I obserred also that the spine terminating the posterior tibire is more bent upon the base of the tarsi, even than in my figure 4 . I have seen no male which will agree with this intermediate female in the colouring of the elytra. As however, upon a rigid examination and comparison of male specimens with the elytra much suffused with black (fig. 2), and those with the black occupying only about one-third of each elytron, I have failed in detceting any specific distinction between these two insects; I can but consider them as varieties of one species. I beheve them, however, to be constant and local, the darker ones being imhabitants of China, whilst the lighter ones inhabit Sylhet.

The species with its varieties may therefore be thus arranged:-

LUCANUS (ODONTOLABIS) GAZELLA.

1st Typical Variety on Geographical Sub-species. Elytra half black and half pale fulvous. Hab. Siam. (Lucanus Giazlli proper.)

2nd VARietr or Geographical Sun-Species. Elytra one-third klack and two-thirds pale fulvous. Hab. Sylhet.

lst Sub-variety of the male with large mandibles having a strong tooth near the base (Lucanus Curera), Hope in Linn. Trans. xix. p. 105, pl. x. fig. 3.

2ud Sub-variety of male with the basal tooth of mandilles wanting (Lucanus Prinseppii), Hope : Cat. Lucan, pp. 5 \& 16 ; and my Plate 26, fig. 5. Hab. liasyah hizls. In Mus. Hope.

Ird Sub-variety of the male with the mandibles not quite so long as the bead, with five or six rouuded irregular teeth in each (Lucanus bicolor Tar.), Saunders in Traus. Eut. Soc. ii., p. 177, pl. 16, fig. 3; L. Saundersii Hope, Linn. Trans. xix., p. 105 4th Sub-variety of the male, with the external teeth of all the tibire obliterated (Lucanus Anoploenemus Burmeisteri), Hope in Trans. Ent. Soc. ii., p. 279, pl. 13, fig. 3. Hab. Mysore. The only difference which I have been alle to detect between this gigantic insect aud $L$. Curera Hope, (L. Tr. xix., pl. 10, f. 3, ) consists in the still more elongated mandibles, the sides of the bead behind the eyes with the two spines nearly obliterated; as well as the cxternal teeth of all the tibire. I believe these peculiarities will prove to be abnormal and not specific ; in other words I consider the specimen so far moustrous.*

Female (Lueanus Delessertii Guér. Mín.) Sonv. Voy. Deless. Ins. pl. 12, fig. 3.

3rd Variety or Geographical Sub-specifs. Elytra black with a fulvous margin about one-third of the width of the elytra. Hab. China. (Lueanus, Odontolabis, Crazclla, Sinensis, Westw.)

1st Sub-variety of the male with large head and mandibles, the former with the fore margin elevated, and the latter armed with a strong tooth near the base, another obtuse beyond the middle aud several small ones near the tip. (Plate 26, f. 2, 2a, mentum, 2 b, 2 c, mesosternum.) In Mlus. Parry.

2nd Sub-variety of the male, with smaller head, the fore margin not being elevated, and the mandibles not so long as the head, elongate-trigonate interually serrated, (Plate 26, f. 3). In Mus. Westwood, communicated by J. Plant, jun., Esq.

Female with the head not armed with a spine on each side behind the eyes, middle tibire without the small lobe at the apex within (Plate 26, fig. 4, 4a, mentum more deeply punctured than in the male, and not elevated in the middle ; $4 \mathrm{~b}, 4 \mathrm{c}$, mesosternum.) In Mus. Parry.

FIGURE 6.

LUCANUS (ODONTOLABIS) CASTANOPTERUS. HOPE.

Observations.-The male of this species is represented in Plate 10, fig. 5, copied from the largest individual of this sex which I have hitherto seen. From the size of the mandibles it might be mistaken for a female, but the dissection of the abdomen has proved it to be of the opposite sex. I have seen other males not larger than the female represented in the present plate. In both sexes the fore tibiæ are very broad and serrated (fig. 6 e, fore tibix of male), but the most striking distinction consists in the mentum, which in the male (fig. $6 \mathrm{~d}$ ) is densely hairy; whilst in the female (fig. 6 a) it is nearly naked; the mesosternum is obtuse (fig. $6 \mathrm{~b}, 6 \mathrm{c}$ ). The female appears to be mueh rarer than the male. The specimen of the former sex now represented (in order to complete the illustration of the species) is contained in the Kirbian Collection in the possession of the Entomological Society of London.

This species belongs to the second section of the sub-genus Odontolabis, in which the head of the males has the sides behind the eyes not spined, containing also L. Glabratus, De Haan; L. Baladeva, Hope, \&c.

* I possess a specimen of L. glabratus De H. in which the tibial spines of the fore legs are also obsolete. 



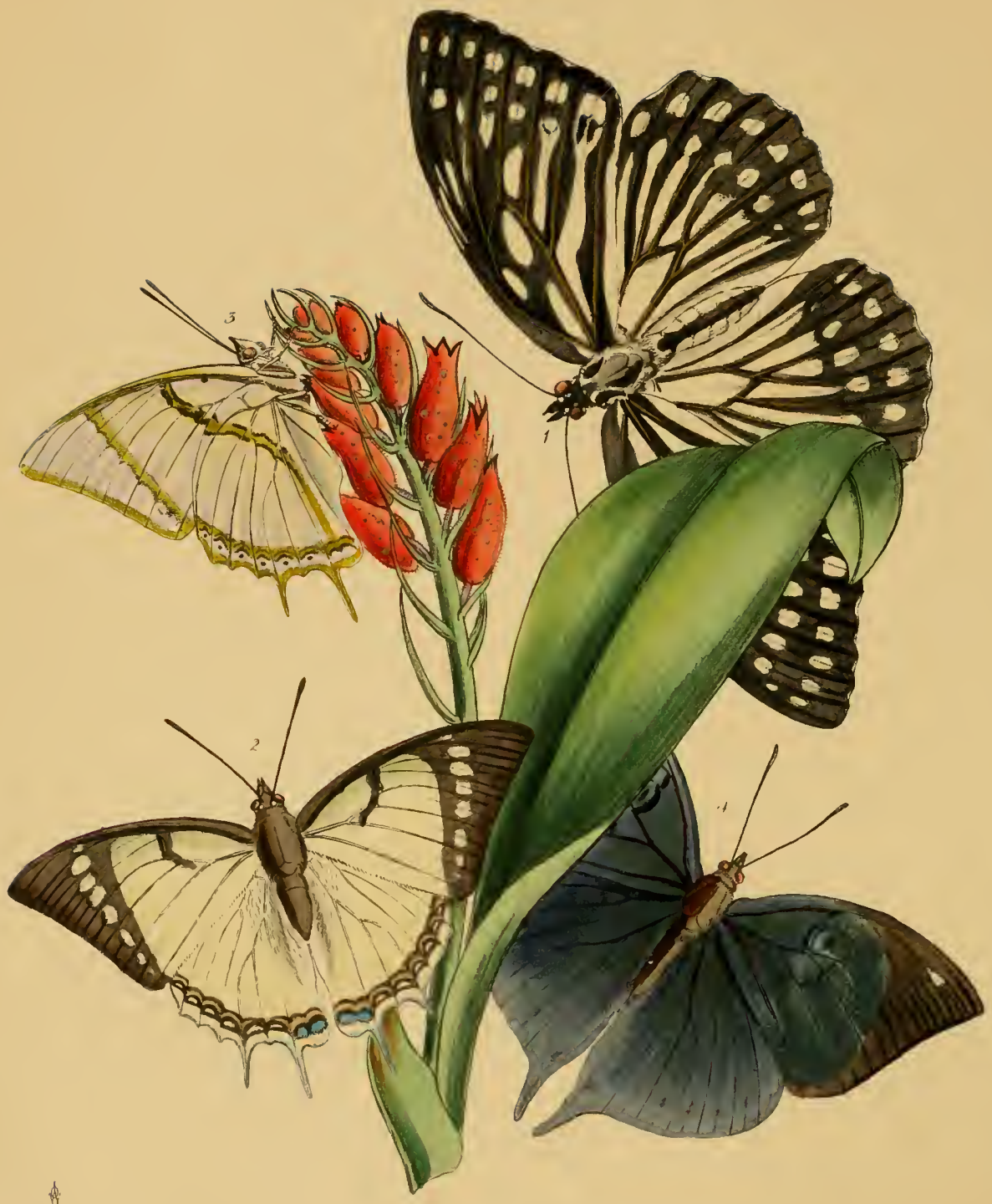






\title{
PLATE XXVII.
}

(ORDER-LEPIDOPTERA. Secton-Diura. Family-Nympialid. Swaisson.)

\author{
FIGURE 1.
}

NYMIPIALIS EUPIIRONE. WESTW.

Nymphalis alis fusco-nigris maculis strigisque numerosis albis, subtus fulvo-fuscis, anticis obscurioribus, maculis strigisque nt in paginat superiori ; ahdomine allo vitta fusea dorsali.

Nymphalis with the wings on the npper side of a brownish-black, marked with numerous white spots and stripes; beneath of a fulvous-brown, thic fore ones darker brown, except at the tips, all marked as above, with white spots ; ablomeu white, with a dorsal stripe of blackish-brown.

Expansion of the fore wings nearly $5 \frac{1}{2}$ inches.

Inhabits Assam. In the Collections of Britisl Museum, Westwood, \&c.

Description.-This specics is nearest allied to a tropical African species, figured by Donoran in his Insects of India, pl. 34, fig. 3 and others, under the name of Papilio Eurinome, and which forms a distinct sub-genus next to Diadema. In the species before us there is scarcely any distinction between the appearance of the two sexes. The wings are large and broad, with the apical margins slightly sinuose; the fore margin of the forc wings is rounded. The wings on the upper side are of a brownish-black colour, the discoidal cell with three large oval white spots, one near the base and the two others placed obliquely. These are followed by a very much curved series of about ten white stripes, varying in size and length, the innermost one occupying ncarly the whole of the inner margin of the wing; beyond these are two rows of white spots, seven in each row, the imnermost one in the anterior row being confluent with the preceding white dash. The discoidal cell in the hind wings is white, separated by brown veins from a series of white streaks, the innermost of which occupies nearly the whole of the anal area; beyond these are two rows of white spots, some of those in the anterior row being more or less confluent with the preceding white dashes. The wings are marked beneatl as on the upper side, the ground colour of the hind pair being of a fulvous-brown, whilst that of the fore wings is brown, gradually becoming paler to the tips. The head, palpi, and thorax, arc black, spotted with white; and the abdomen white, with a dorsal band of blackish-brown, the sides also with a row of small black dots.

I am indebted to Major F. Jenkins for my specimens of this fine butterfly.

\section{FIGURE 2.3.}

CHARAXES DOLON. WESTW.

\footnotetext{
Charaxes alis supra stramineo-albis, anticis costa cum macula ad apicem aree discoidalis fimbriaque lata marginis externi (in qua series unica macularum albarum) nigricantibus; posticis bicaudatis vitta submarginali nigricanti lunalas albidas duplici serie amplectente ; alis subtus margaritaceo-albis, costa strigisque duabus communibus (nigro plus minusve marginatis) margineque apicali subfulvis, posticis etiam serie submarginali punctorum nigrorun, ablomine fusco.
} 


\begin{abstract}
Charaxes with the wings on the upper side straw-white, the fore ones laving the costa, a conjoined spot at the extremity of the discoidal cell, and a broad apical margin of black, the latter bearing a single row of about eight white spots; the hind wings bicandate, with a subapical narrow fascia of brownish-black, in which are two rows of small whitish lumles; the tails bluish-grey, the inner ones preceded by two blue-white spots; all the wings beneath pearly-white; the costa of the fore wings (except at the tip) and two narrow fascire common to all the wings, and more or less edged with black, as well as the apieal margin dull fulvous; the hind wings with a submargiual row of black dots; abdomen brown.

Expansion of the fore wings $3 \frac{1}{2}$ inches.

Inlabits Malwah in the East Indies. In the Collection of Captain Boys.
\end{abstract}

Observatrons.-This pretty species is mique in the fine collection recently brought home by Captain Boys, who has kindly allowed me to figure it and other new species. It is closely allied to the Assamese Char. Eudamippus, Doubleday (Anu. Soc. Ent. France, 1843, p. 218, pl, S), which I have received from Major Jenkins, but differs in its smaller size, the lirection of the dark patch at the apex of the discoidal cell, the siugle row of white spots in the broad dark apical margin, the dark costa of the fore wiugs beneath, the single minute black dot in the discoidal cell adjoining the costa, the more regular fascia at the extremity of the discoidal cell, the want of the black oblique line in the anal area of the hind wings, and in the brown abdomen, which is pure white in Eudamippus.

\title{
FIGURE 3. .
}

\section{AMATHUSIA PHILARCHUS. WEST.}

\begin{abstract}
Amathusia nigro-eæruleis virili-tinetis apicibns anticarum late nigris puteto albo subapicali; fascia lata obliqua poue medium argenteo-crerulescenti, lineolis nonnullis obscuris prope medium alanm; posticis concoloribus angulo anali caudato; subtus fusco-griseis, fusco irroratis ; striga tenui fusca communi ocellisque duobus abseuris pone medium posticarum serieque submarginali fere indistincta punctorum alborum.

Amathusia with the wings of a blue-black colour tinged with green, the tips of the fore ones broadly black, with a white dot near the apex; beyond the middle of the fore wings is a broad oblique silvery blue fascia, having several dark blue-black obscure short lines near and below the tip of the discoidal cell ; the hind wings are concolorous, with the anal angle tailed; beneath, the wings are of an obscure greyish-brown, freckled all over with minute brown irrorations; a slender brown streak extends across all the wings (crossing the middle of the hind wings and extending from the apical angle of the fore wings to the anal angle of the hind ones, where there is also another short brown parallel streak); half way between the middle of the lind wings and the anal angle are two very obscure ocelli smrounded by whitish rings, and there is a very indistinct row of mimute whitish dots, rumning parallel with the apieal margin of all the wings; the body is entirely brown.
\end{abstract}

Expausion of the fore wings $3 \frac{9}{4}$ inches.

Inlabits the Island of Ceylon. In the Collection of R. Templeton, Esq.

Observations. - This species is nearly allied to Amathusia Paralekta of Horsfield (Lepicl. Java, tab. 6, fig. 4), a species which seems to range all over India*, as Dr. Royle brought it from the Himalayas, figuring it in his work on that part of India from a native drawing. The dull colours of the underside of the wings of the present species, when closed, as well as of A. Paralekta, give the insects all the appearance of so many withered leaves, which deception is greatly increased by the dark streak which runs along the middle of the wings, and which may be easily mistaken for the midrib of the leaf.

The insect before us is at once distinguished from A. Paralekta by its colours, and by wanting the small talc like spots in the fore wings.

The plant figured is the Orchidaceous Cryptochilus sanguinea of Wallich, from Northern Iudia.

* The contineutal specimens are much more variegated in their markings, their fore wings more acutely pointed at the tips, and the tails much longer, than in Dr. Horsfield's figure of the Javanese specimens. 


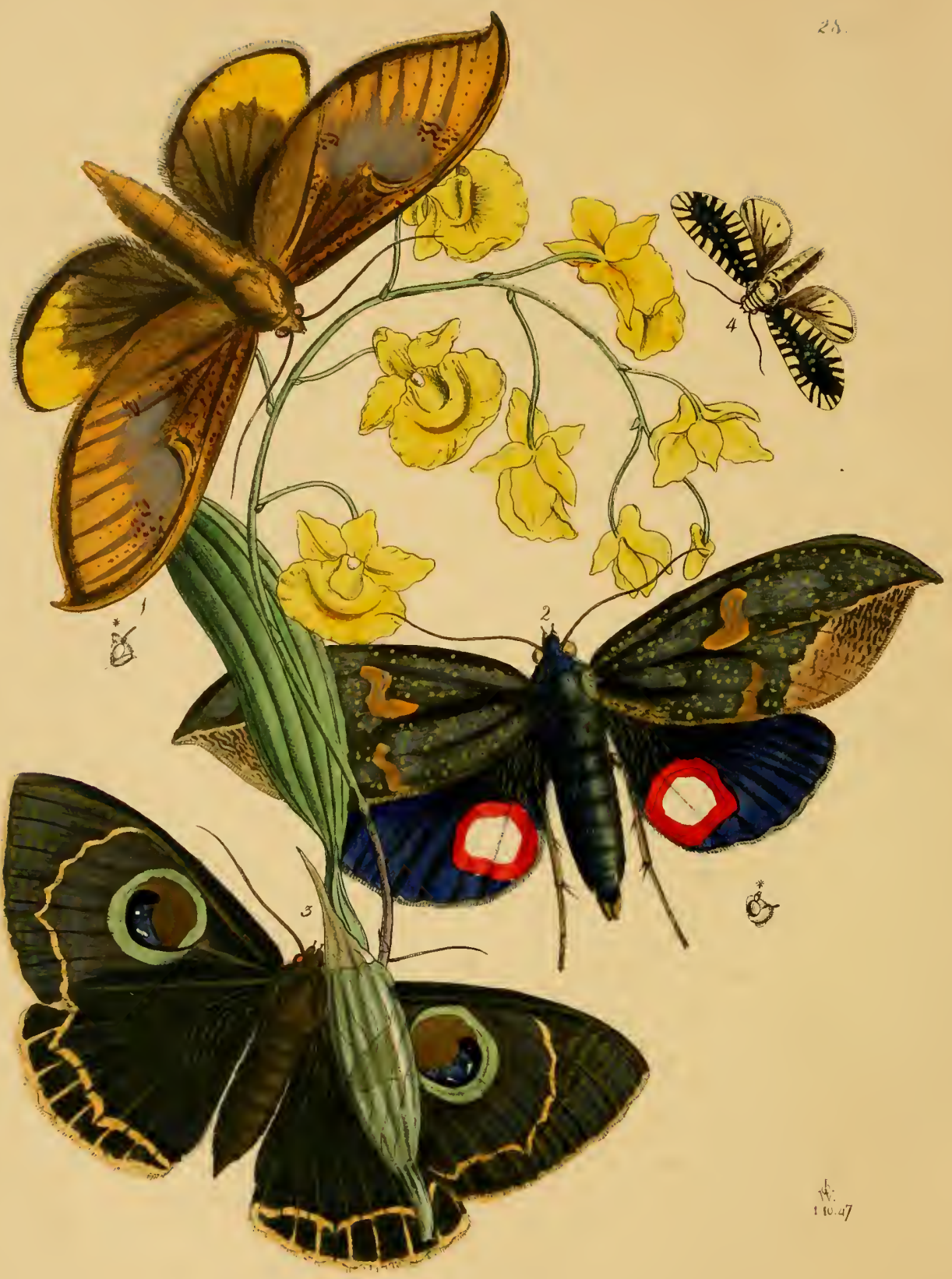





$$
\text { , }
$$




\title{
PLATE XXVIII.
}

\author{
(ORDER-LEPIDOPTERA. \\ Section-Nocturna. \\ Family-Noctude. Leach.) \\ FIGURE 1. \\ PHYLLODES USTULATA. WEST.
}

Phyllodes alis anticis cllipticis ajice faleatis, fuscis, brumueo variis plaga magna versus apieem magis livida, stigmate medio oblinno sublunato; postieis fuseis augulo externo late fulvo ; onnibus subtus fuscis apieibus fulveseentilns.

['hyllodes with the fore wings clliptic, having the tip falcate, brown, varicd with brighter brown irrorations, and having a large livid pateh near the apex : the characteristic stigma in the middle of the wing is vexy oblique and slightly lunate; hind wiugs brown, with a broad fulvous patch on the outer angle ; bencath all the wings are brown with a fulveseent margin. The fore wings have a leaden gloss in the middle. The body is brown, with a leaden gloss on the liead and front of the thorax.

Expansion of the fore wings nearly 5 inches.

Inlabits Sylhet. In the Collection of II. G. Harrington, Esq.

\section{FIGURE 2.}

\section{PHYLLODES CONSOBRINA. WESTW.}

Phyllodes alis anticis ellipticis apice minus faleatis, fuscis plumbeo nitidis luteo irrorntis, plaga magna marginis apicalis subluteo fuseo varia; stigmate magno sigmoileo obscure fulvo, alis posticis nigro-ereruleis macula nagna anali ehermesina medio alba, alis anticis subtus medio albis venis nigris, postieis ut supra coloratis.

Plyyllodes witls the fore wings elliptical, the tips less falcate than in the preceling species, brown glossed with plumbcous, irrorated with luteous and with a large dirty fulvous patch, varied with brown, along the apical margin; the stigma is large and somewhat S-shaped, of an obscure fulvous colour, inclosing two black curved lines; the hind wings are blue black, with a large carmine nearly-circular spot with the middle whitc; at the anal angle, the fore wings beneatb are white in the middle with the veins broadly black; the hind wings are coloured as on the upper side.

Expansiou of the fore wings $5 \frac{1}{2}$ inches.

Inhabits Sylhet and Assam. Communicated by Major F. Jenkins.

Observations.-This beautiful insect, described by Fabricius from the British Museum Collection, has been confoumded by Boisduval with another closely-allied species, from the Indian Islands, figured br Cramer, the distinctions of which may be thus stated :-

PHYLLODES CONSOBRINA, WEST. (CONSPICILLATOR, FAB. E. s. 3, 412 , NEC CR.), stigmate alarum anticarum sigmoideo albo vix notato; alis posticis apice externo coneolori. Sylhet, Assam.

PHYllodes CONSPiCillatoR, Cran, pl. 97, ann Bdv. Vor. de L'Astr. p. 246, pl, 5, fig. 4 (Nec FABr.), stigmate vix sigmoideo albo-bimaculato, alis posticis apice externo albo. Amboyua.

\section{FIGURE 3.}

\section{EREBUS RIVULARIS. WESTW,}

Erebus alis nigris subnitidis; omnibus linea angusta pone medium margineque apicali albidis ; anticis oecllo magno rotundato livide brunneo, obseure viridi, nigroque-cyaneo varïis alboque irrorato: subtus similiter coloratis absque ocello.

Erebus with the wings black with a slight metallie gloss, all with a narrow undulating whitish line beyond the middle of the wings and with the apical margin and cilia whitish, the fore wings having a large rounded ocellus varied with livid ferruginous, obscure green and cyaneous black, and irrorated with white seales on its inner part ; on the under side the wings are coloured as above, but the fore ones are entirely destitute of the ocelhis.

Expansion of the fore wings 5 inches.

Inhabits Sylhet. In the Collection of H. G. Harrington, Esq., de. 


\section{FIGURE 4.}

\section{NOCTUA (APATELA?) RADIANS.}

Noctua alis anticis nigris strigis transversis undulatis valde indistiuetis plumbeis, margine ommi maculis numerosis, intus acuminatis sulphureis, posticis albidis basi anguloque externo nigris; capite et thorace albido trausver'sè fasciatis.

Noctua with the fore wings black, with several very indistinct transverse undulated leaden-coloured striga ; all the margins marked witl a number of sulphur-coloured spots, which are acuminated towards the middle of the wing; hind wings black at the base and outer angle, the remainder whitish, body black, with the head and thorax transversely striped with sulphureous.

Expansion of the fore wings $1 \frac{3}{4}$ inches.

Inlabits Assam. Communicated by Major F. Jenkius.

The orchidaceous plant represented in the plate is the Dendrobium aggregatum of Roxburgh.

The singular plant represented in Plate XXV is the very rare Acanthophippium bicolor, from Java. 


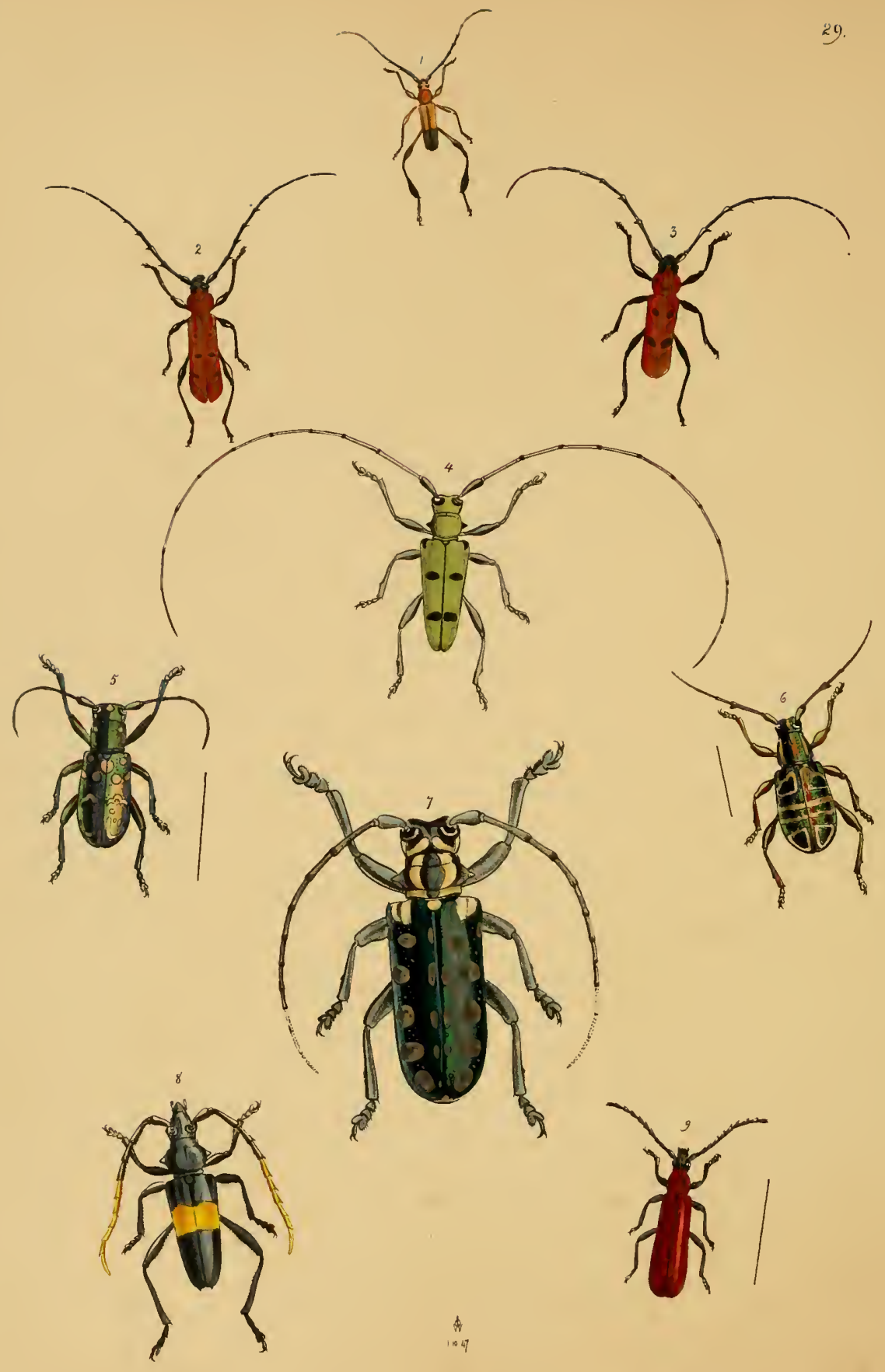






\section{PLATE XXIX.}

\section{(ORDER-COLEOPTERA.

\author{
SEction-Longicornes.
} \\ Family - Cerambycid.e. Leach.) FIGURE 1.

\author{
CERAMBYX (s-o. Nor.) TELEPIIOROIDES. WEsTw.
}

Cerambyx depressus thoracis Iateribus incruibus, clytris apice trumeatis, antcunis corpore longioribus, pedibus clongatis femoribus clavatis tibiis posticis dilatatis; testacens, setoso-sericeus, clytris fulvis, apicibus uigris : antemis nigris apice fuscis, articulis 7 et 8 albidis ; pedibus nigris, femoribus basi fulvis.

Cerambyx with the body depressed, the sides of the thorax not spinal, the elytra with the tips truncate, the antenure longer than the body, the legs long with the thighs thickened and the posterior tibix dilated, testaceous, setose-silky, opaque, with the elytra fulvous, the tips black; the anteunre black with brown tips, the 7 th and 8tli joints buff. coloured; legs black, the femora fulvous at the base.

Length of the insect 6 lines.

Inhabits Ceylon. In the Collcetion of R. Templeton, Fsq.

\section{FIGURE 2.}

\section{PLRPURICENUS 10-PLNCTATUS. WESTW.}

Purpuriccnus niger pronoto coccineo 4-punctato, elytris coccincis 8-punctatis punetis duobns anticis latcralibns, reliquis dorsalibus, omnibus nigris ; corpore subtus nigro collo coccineo.

Purpuricenus black, with the prouotum scarlet with 4 black spots, the elytra also scarlet with 8 black spots, the two anterior being lateral the others dorsal; body beneath black with the collar scarlet. (The female is similar, lut has shorter antennæ.)

Length of the insect $10-11$ lines.

Inlahits Assam. Communicated by Major F. Jenkins.

\section{FIGURE 3.}

PURPURICENUS 9-PUNCTATUS. WEST:

Purpuricenus fulvo-rufus, capite, antennis, punctis 3 pronoti, scutcilo, 1 unctis 6 elytrorum (2 parvis latcralibus, 4 dorsalibus, ultimis duobus fasciam interruptam formantibus), coxis omnibus, mesostemo, et apice abdominis, nigris.

Purpuricenus fnlvous-red, with the head, anteunæ, 3 spots on the pronotum, scutellum, 6 spots on the elytra ( 2 small and lateral, 4 dorsal, the two hinder ones forming an interrupted fascia), all the coxæ, the mesosternum, and the apex of the alodomen, all black.

Length of the insect 10 lines.

Inhabits the Island of Jara. In Mus. Westw. Communicated by Dr. Burmeister.

\section{FIGURE 4.}

\section{MONOHAMMUS BIFASCIATUS. MELLY MSS.}

Monohammus niger griseo-villosus; capite, pronoto, elytrisque fulvescentibus, his fasciis dnobus interruptis scutelloque nigris, antennis pedibusque griseo-villosis, illarum articulis apicibus nigris, corpore sulotus obscurè fulvescenti, lateribus pronoti et elytrorum griseis.

Monohammns black with grey pile; the head, pronotum, and elytra fulvescent, the latter with two interrupted black fascix, black scutellum, black antennæ, and legs covered with black pile, the tips of the joints of the former black, the body beneatli dirty fulvous, and the sides of the thorax and clytra grey.

Length of the insect 1 inch.

Inhabits the Himalayas. In the Collcetion of A. Melly, Esq. 
FIGURE 5.

ABRYNA EXIMIA. News. (Exton. p. 298.)

Abryna viridi-æenea, maculis impressis lanuginosis albis, antennis nigris submetallicis ; facie macula, pronoto utrinque maculis 4 , elytrisque eirciter 18 , magnitudine et forma variis albis.

Abryna brassy-green, sbining, with impressed white woolly spots, the antennæe black submetallie (3rd aud 4 th joints grey at the base), face with an oblong spot, pronotum with 4 spots on each side and the elytra with about I8 spots varying in size and form, all white.

Length of the inseet 9 lines.

Inhabits the Matrillas (D. Cuming). In the British Museum.

\section{FIGURE 6.}

\section{DOLiofs geometrica. Waterhouse. (Trans. Evt. Soc. iv. 44.)}

Doliops splendide viridi cuea, vel euprea, eapite lineis, prouoto lineis margiualibus et supra hineis tribus (unâ abbreviatâ) notato ; elytris lineis duabus transversis medium versus, ad basin areâ irregulari, ad apicem areâ triangulari ; lineis pallidis alho squamosis eircumdatis ; antennis articulo 3 tio et sequentilun ad basin rufescentibus.

Doliops splendid brassy or eoppery-green, the head with three lines, pronotum with marginal and three dorsal lines, the middle one abbreviated, elytra with two transverse lines near the middle, and with an irregular space near the base of each, and with a triangular space near the apex of each, surrounded by palc lines, all the lines being formed of whitish seales; 3rd and following joints of the antennæ reddish at the base.

Length of the insect 7 lines.

Inhabits the Manillas. (D. Cuming.) In the British Museum.

\section{FIGURE 7 .}

\section{ANOPLOPHORA LUCIPOR. NEWM. (ENTOM. p. 275.)}

Anoplophora, capite obscure nigricanti pone oeulis nacnlis 2 obliquis pronotiquè eoneoloris strigis duabus dorsalilras albido lanuginosis ; elytris viridi-cyaneis uitidis maculis 22 punetisque numerosis albis ; antenvis pedibusque griseo-nigricantibus.

Anoplophora with the head obscure, blackish, with two oblique patches behind the eyes; the pronotum similarly coloured, with two broad dorsal streaks, of a buff colour, and woolly; elytra cyaneous-green, shining, with 22 spots and numerous miunte dots of white; antennæ and legs greyish-blackish.

Length of the insect 2 inches.

Inlabits the Manillas. (Cuming.) In the British Museum.

\section{FIGURE 8 .}

PACHYTERIA DIMIDIATA. WESTW.

Pachyteria cyaneo-nigra, pronoti lateribus spinosis, elytris fascia ferè mediana lata, anteunarunque artieulis 6 nltimis albidis; corpore subtus nuagis cyanea nitida.

Pachyteria black, slightly eyaneous, the sides of the pronotum spined; elytra with the outer apical angle dentated, and with a broad buff-eoloured faseia nearly across the niddle ; six terminal joints of the antenna buff ; body beneath more cyaneous and shiuing.

Length of the insect $1 \frac{1}{4}$ inch.

Inhabits Assam. Communicated by Major F. Jenkins.

\section{FIGURE 9.}

\section{SAPLRDA (s-G. Nov.) BICOLOR. IVESTw.}

Saperda? nigra, pronoto elytrisque coceineis, illo nigro-binaculato, eapite subrostrato, antennis brevibus crassis articulis 5 et reliquis serratis, pronoto conico truncato, lateribus inermibus; elytris convexis apice rotuudatis, pedibus brevibus simplicibus.

Saperda ? black, the pronotum and elytra carmine-coloured, the former with two black spots; the head elongated in frout into a short thick rostrum ; anteunæ short, thick, the 5th and following joints serrated ; pronotum conical, truneated, convex, the sides unarmed ; elytra convex, rounded at the tips ; the dise with elevated longitudinal lines; legs short and simple.

Length of the insect 9 lines.

Iuhabits Assam. Communicated by Major F. Jeukins. 



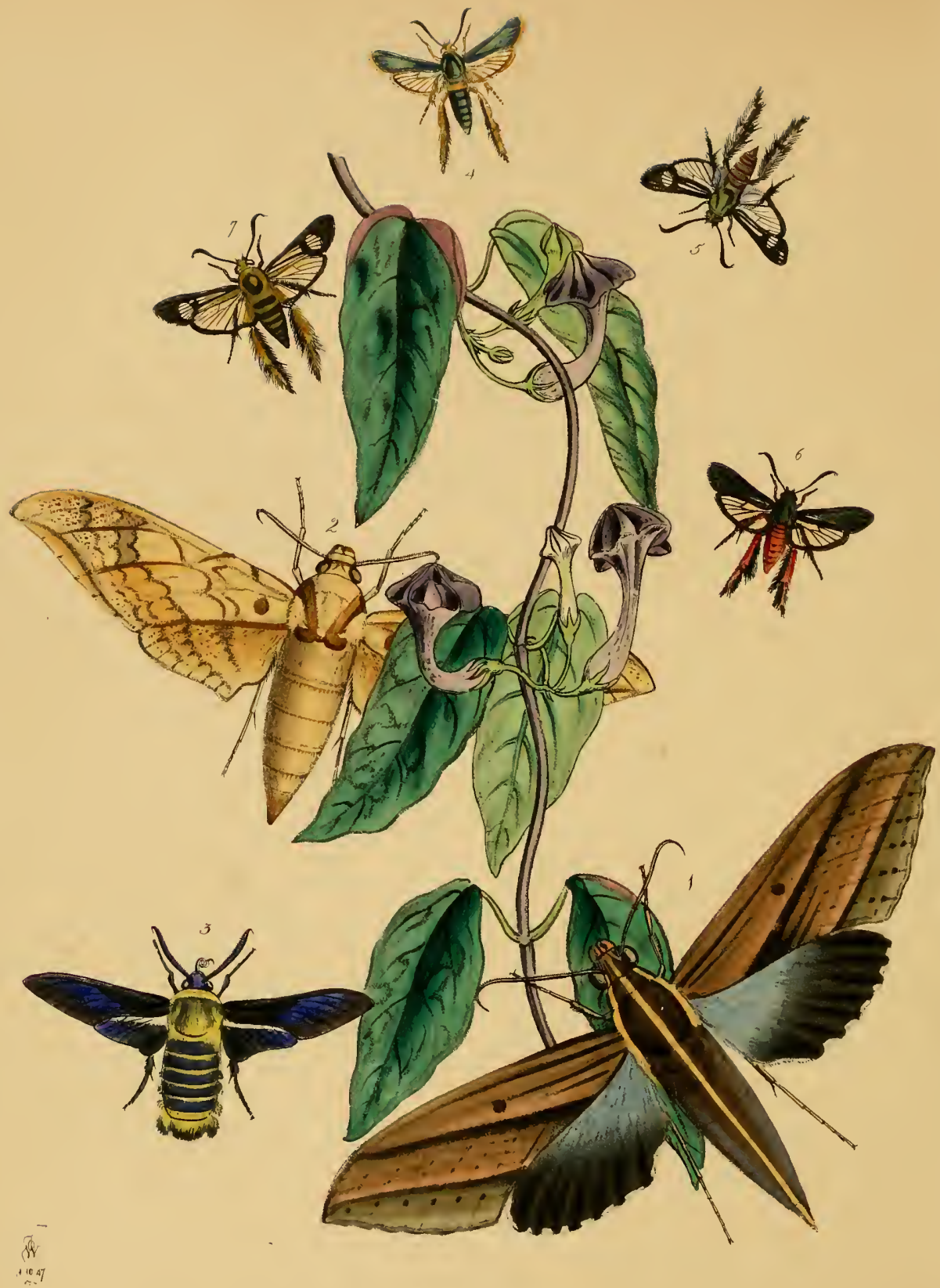





\title{
PLATE XYY.
}

\section{(ORDER-LEPid OPtera. Section-Crepuscularia. Latreille.)}

\author{
FIGURE I.
}

\section{SPIINX (CHCROCAMPA) DOLICJIUS. BDV. MISS,}

Sphinx alis antieis earneo-fuscis, strigis mumerosis obliquis obscurioribus duabus fulvo-luscis ; puneto medio fuser, venisrue fusco punctatis; alis postieis basi plumbeis apice fuseis, eilia alba fuseo punctata ; corpore fusco capite et thorace lateribus vittiłque mediât (ad apieem abdominis extensâ) pallidis.

Sphinx with the fore wings fleshy-brown, with numerous obhique dusky strigre, two of which aro dark fulvous brewn, a brown spot in the middle of the wing, and the veins dotted witl brown; hind wings leaden blue at the base, the apieal pertion brown, fringe white spotted with brown; body brown; the heal anl thorax with the sides and a central streak extending to the tip of the ablomen, of a paler colour.

Expansion of the fore wings nearly $5 \frac{1}{2}$ inches.

Inhabits Sylhet. In the Collection of the British Museum, W. W. Saunder's, Esy., de:

FIGURE 2.

\section{SPHINX (AMBULYX) SUBSTRIGILJS. Westw.}

Sphinx eorpore supra alisque antieis palide fusco-allidis, his versus apicem fusco-punetatis, macula prope basin strigisque duabus ante medium valde flexuosis, atueo-fulvis; strigisque trilus undatis pone medium, spatio iutermeñio magis fulvo, striga alia curvata submarginali fusea; alis posticis fulvis fusco-punctatis fascin media recta ; secunda dentata poue medium tertiaque abbreviata ad angulum externum fuscis; thorace strigis duabus latis obliquis fasciaque postica aureo-fulvis.

Splinx with the body above and the fere wings of a pale brownish buff colour, the latter spotted with brown near the apex, a spot near the base and two very flexuous streaks before the middle of the wing, of a goldeu fulvous colour ; three waved streaks beyond the middle, the intermediate spaee being more fulvous, and a slightly curved striga near the apieal margin of brown; hind wings fulvous, spotted with brown, with a straight faseia across tle middle, a second dentated beyond it, and a third abbreviated near the outer angle, brown ; thornx with two oblique broad stripes, and a transverse posterior faseia of golden fulvous.

Exprusiou of the fore wings nearly $4 \frac{3}{4}$ inches.

Inlabits Sylhet. In the Collection of the British Museum.

\section{FIGURE 3.}

SESIA INFERNALIS. WESTW.

Sesia nigra alis anticis nigris pune medium cyanco-nitidis; posticis nigris eosta alba; eorpore nigro-cyaneo, thorace flaro migro subfaseiato; abdomine fascia subapicali flava, eauda, faseieulisque laterabibus nigris flavo squamosis.

Sesia black with the fore wings black, glossed with eyaneous blue beyond the middle; hind wings black, with the costa white; body cyancous black; thorax above yellow, indistinetly fasciated with black; abdomeu with a subapical yellow fascia, the tail and abdominal tufts black, varied with yellow seales.

Expansion of the fore wings $2 \frac{1}{3}$ inches.

Inhabits Sylhet aud Assam. Communieated by Major F. Jenkins, and W. W. Saunders, Esq.

\section{FIGURE 4.}

\section{TROCHILIUM ASTARTE. WEST,}

Trochilium alis anticis nigro-æneis, nitidis eilia lata fulva; posticis hyalinis venis ciliaque fulvis margine apicali nigricanti ; capite et eollari fulvo, corpore nigro-zeneo, abdominis basi apiceque fulvis ; antennis nigris faseia pene medium plumbea ; pedibus fulvis nigroque variis posticis clongatis valde barbatis, barba extus fulva, albo variegata, intus nigra.

Trochilium with the fore wings brassy black and glossy, with a broad orange fringe ; hind wings glassy, with orange-eoloured veins and fringe, the latter preceded by a black marginal line; head and cellar fulvous; body brassy black, with the baxe and apex of the abdomen orange; antennx black, with a leaden-coloured ring beyond the- 
middle ; legs fulvous, varied with black ; hind legs rery long and bearded, the beard outwardly orange, slightly raried with white, inwardly black.

Expansion of the fore wings $I$ inch.

Inhabits Ceutral India. In the Collection of Colonel Hearsey.

\section{FIGURE 5 .}

TROCHILIUM EURYTION. WEST.

Trochilium alis anticis nigris strigis duabus longitudinalibus plagarue pone medium (renis divisa) hyalinis, posticis hyalinis cilia venisque gracillimis nigris, regione anali argenteo-carulescenti ; capite et pronoto obscure æeneo opacis; abdomine nigro segmentis albo squanosis; pedibus nigris, plumbeo variegatis, posticis elongatis valde barbatis barba griseo et nigro rariegata.

Trochilium with the fore wings black, with two longitudinal hyaline strige, extending to the middle of the wing, beyond which is an oval hyaline patch, divided by three veins; hind wings hyaline, with the fringe and the slender veins black, anal region silvery blue; head and pronotum obseure, brassy, opague ; abdomen black, with the segments varied with white scales; legs black, variegated with leaden-coloured seales; the hind pair elongated and densely bearded, the beard being formed of thin grey and black hairs.

Expansion of the fore wings, 14 lines.

Iubabits Sylhet. In the Collection of H. G. Harrington, Esq., and the British Museum.

\section{FIGURE 6.}

TROCHILIUM CETO. WEST.

Trochilium alis anticis nigris parum reneis, striga tenui, hyalina ante medium longitudinali; posticis hyalinis venis gracillimis ciliaque nigris, corpore nigro, abdomive aureo-rufo, segmentis macula nigra basali; pedibus aurantiis tarsis intermediis nigris albo annulatis, posticis elongatis et valde barhatis; barba extus rufa, albo parum squamosa intus nigra.

Trochilium with the fore wings black, slightly tinged with æeneous, aud with a very slender byaline longitudinal streak before the middle of the wing; hind wings hyaline, with the very slender veins and a broad fringe of black; body black; abdomen golden red, the joints with a black spot at the base; legs orange, the middle tarsi black with white rings, hind legs rery long and much bearded, the beard ontwardly red, shightly marked with white scales, inwardly black.

Expansion of the fore wings nearly $1 \frac{1}{4}$ incl.

Observations. - This species mas communicated to me by H. G. Harrington, Esq., as a native of India. It is, I beliere howerer (on the authority of specimens in the British Museum), a natire of North America. It has been confounded with the Zyg. tibialis of Fabricius and Drury, which is a natire of Tropical Africa. Mr. Dyson has bronght another beautiful closely-allied species from Venezuela, of which specimens are in the British Mnseum.

\section{FIGURE 7.}

\section{TROCHILIUM PHORCUS. WESTW.}

Trochilium alis anticis nigris intus fulvis strigis duabus longitudinalibus maculaque subtriangulari ante apicem (renis dirisis) hyalinis; posticis hyalinis renis ciliaque nigris, area anali fulva, thorace et basi abdominis necnon incisuris abdominis fulvis, pedibus fulro nigroque varüs; posticis elougatis densè barbatis barba tibiarum extus fulva intus cum tarsis nigris.

Trochilium with the fore wings black, the inner margin fulvous, with two longitudinal streaks extending beyond the middle of the wing, and a somewhat triangular subapical spot (divided by four longitudinal reins) hyaline ; hind wings hyaline with the slender veins and the cilia black, anal area fulvous, legs varied with fulvous and black, the bind ones elongated and densely bearded, the beard of the tibix outwardly fulvous, inwardly as well as that of the tarsi, black.

Expansion of the fore wings nearly $1 \frac{1}{2}$ inch.

Inhabits Central India. In the Collection of Colonel Hearsey.

Observation.-Closely allied to, but smaller than, Sphinx Bombyliformis of Cramer, pl. 400, fig. C.

The plant represented in the plate is the Ceropegeia elegans from the Nilgherry Hills. 


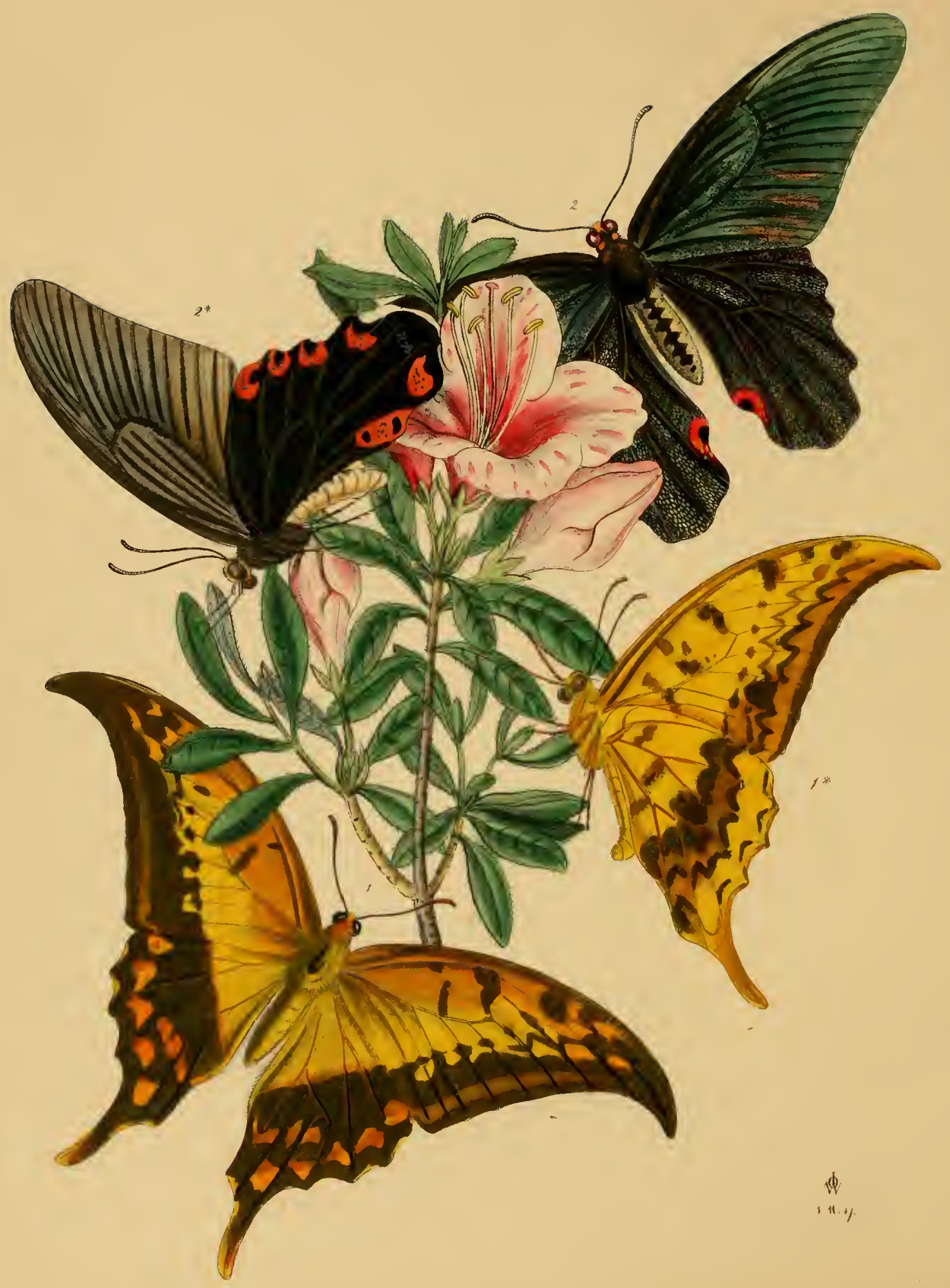






\title{
PLATE XXXI.
}

(ORDER-LEPIDOPTERA.

\author{
Section-Divkxa.
}

FaMLX-PaplLLOID.x.)

FIGURE 1, AND I**

Pal'llo EVAN. Doublemay. (AN. Nat. IIst, xvi, 235 and 304.)

\begin{abstract}
Papilio alis anticis clongatis falcatis acuminatis, posticis clongatis dentatis eaudatis omnibus lutco-rufis, margine externo late fnsco-bronnco, maculis lunulisque luteo-rufis.

Papilio with the fore wings elongate, siekle-shaped, acuminated; hind ones clongated, dentated, tailed, all luteous red, with the outer nargin broadly brown with luteous red spots and lunules.

Expansion of the fore wings, 5 to $6 \frac{1}{2}$ inches.

Inlabits Sylliet. In the Collections of the British and Aslımolean IIuseums, and W. W. Sannders, Esq.
\end{abstract}

Descriptios.- "Antcrior wings elongate, falcate, acuminate, of bright light fulrons, the base and anterior portion of the costa more obscure, the costa from the middle to the apex and exterior margin decp brown, with fulvous spots at the apex and anal angle; a sigmoid spot in the cell and a larger spot on the disco-cellular nervurc of the same colour as the margin. Postcrior wings elongate, dentate, caudate, light fulrous at the base, decp fuscous brown beyond; a scrics of five lunulate light fulvons spots near the onter margiu, preceded by three spots and a striga of a decper fulrous near the anal angle, the tail fulvous brown, paler towards the apex. Cilia marked with pale fulvons near the outer augle. Below the wings arc bright yellow ochre coloured, the anterior with sereral irregular spots in the ecll, a larger one on the discoidal, three on the costa near the apex, a fourth below the last of these, followed by a zigzag linc, and the outer margin light brown; the margin is marked with lighter coloured clonds, and preceded by some indistinct spots on the ncrvures morc or less confounded witl it. The postcrior wings have four brom spots at the base, a broad band beyond the middle of deep rich brown, extending aloug the abdominal margin to the tails, which are brown. This band is marked antcriorly between the ncrvules with silvery atoms, those nearest the iuner margin forming a silvery hmulc. Beyond the band the wings are of the same colour as at the base, with four sigmoid spots, a narrow line on the margin itself, and the cilia at the ends of the nervules rich brown. Head and antenna bromn. Thorax bright shining black, corered at the sides with brown hair and seales, apparently naturally almost bare on the dise; abdomen very pointed, liteo-fulrous." DoubleDAY, l. c.

"Fcmale much larger than the male, the rrings expanding $l_{\frac{1}{2}}$ inch more; fore wings less falcate, their colour above much paler, base not shaded with fuscous : the spot on the disco-cellular nerrule is more distinct; there are two or three irregular daxk spots in the eell; the dark border is narrower and not quite of so deep a colour; the light fulvous spots are more distinct, the posterior wings paler, witl the dark margin much narrower; the inner row of spots very distinet, the indentations and tail pale fulrous, and the under surface is much paler." (Doubleday, l. c., and Gen. Diurn. Lepid. pl. 2).

IIr. Edward Doubleday considers this specics as distinct from Papilio Payeni (Van der Hocren), on account of its larger size and from the hind wings not being dentate, and in the broad deep-brown band below. From the identity, howcrer, of thcir characteristic markings, I cammot bnt think that the two 
supposed species are merely local varieties, those from the islands not being so much suffused beneath with brown. As to the distinction drawn from the dentate margin of the hind wings, $I$ have but little doubt that Van der Hoeven's figure is incorrect in this respect.

FIGURE 2. AND 2*.

PAPilio ElEpienoR. Dovbleday. (Op. Cit. p. 305.)

\begin{abstract}
Papilio alis anticis elongatis supra nigris viridi irroratis nervulis tribus pubescentibus, subtus pallidis nigro. lineatis ; posticis ovatis elongatis angustatis, dentatis, nigris viridi-irroratis, antice cerulescenti nitentibus, lunula anali rufa, subtus nigro-cæruleis lunulis marginalibus rufis eæeruleo-irroratis.

Papilio with the fore wings elongate, above black, irrorated with green ; three of the inner veins pubescent, beneath pale striped with black; the hind wings ovate, elongate, narrow, dentate, black, irrorated with green, anteriorly glossed with blue, with a red anal lunule; beneath blue black, with red marginal lunules irrorated with blue scales (male).

Expansion of the wings $5 \frac{1}{4}$ inehes.

Inlabits Sylhet. In the British Museum.
\end{abstract}

Description.- "Anterior wings elongate triangular, the outer margin about two-thirds the length of the anterior, the inner bearing the same proportion to the outer margin; black, irrorated witl green, at the base of the discoidal cell and on each side of the nervules, the radial nervure, the fold between that and the first median nervule, the first and second median nervules clothed with long hai's, as in P. Bianor, \&c. Posterior wings elongate-ovate, the abdominal margin nearly straight, the outer quadridentate, black, irrorated with green, the anterior margin shaded with blue, as in P. Bianor, the anal angle marked with an ocellus incomplete towards the margin, the pupil jet black, the iris purplish red, irrorated with light blue. Below the anterior wings are pale, more fuscous towards the apex, the nervures and nervules, four streaks in the ccll, and a series of streaks between the nervules fuscous. Posterior wings fuscous black, with purplish reflections, the anal angle with a large rufous patch pupilled with black, irrorated with blue, surmounted by an intense black cloud, and connected with a larger lunule of the same rufous colour, and also irrorated with blue; the outer angle has an imperfect black pupilled ocellus, followed by three lumules, and in the interstice of the second and third median nervule, a cloud of scattered scales of the same colours, the black ground colour being more intense above all these markings.

"Head buff, vertex and antennæ black; thorax black; abdomen pale, marked down the back with a black streak." (Doubleday, loc. cit.)

The plant represented in the plate is a fine variety of the Azalea Indica. 


$$
\text { A }
$$





\title{
PLATE XXXII.
}

\author{
(ORDER-ORTIOPTERA. \\ Section-Ambelatoria. \\ FAMILY-PHasmide.)
}

FIGURE 1.

BACTERIA SARMENTOSA, Westw.

\begin{abstract}
Bactcria luteo-fusea, (viva viridis ?) capite ovali macula nigra verticis postice furcata ; pronoto fusco-vittato, corpore omni leve, femoribus omnibus spinosis, tibiis anticis valde elongatis fere inermibus, 4 posticis spinulosis; intermediis spinula unica versus basin marginis superi paullo majori, tarsis omnibus articulo basali elongato compresso ; oviductu foeminae valde elongato angusto naviculari.

Bactcria dirty-brown (grcen while alive?) the head oval, having a black spot behind the antennre posteriorly forked, the pronotum with brown streaks; the entire body smooth; all the thighs spined; the fore tibire very much elongated, and nearly destitute of spines; the four posterior armed with small spines ; the intermediate pair, with one of the spines near the base of the upper margin, rather larger than the rest ; all the tarsi with the basal joint clongated, compressed ; the oviduct of the female very long, narrow, and boat-shaped,

Length of the female insect, including the ovipositor, 101 inches.

Inlaabits Sylhet. In Coll. Westw., \&e.
\end{abstract}

OBSERTATIONs.-This species of walking-stick insect is longer than any which I have yet seen. It is represented of the natural size, but its full extent is here decreased by unnaturally bending back the fore legs (in order to bring them into the plate) which in the living insect are directed straight forwards. The head is oval, posteriorly elevated and rather longer than the pronotum; it has two small impressions on the rertex between the back of the eyes; the pronotum is rather longer than broad; the mesothorax is rather more than two inches long, warrowed in front, rather depressed, and entirely simple; the metathorax is $1 \frac{1}{2}$ inch long, of equal breadth throughout; simple, with a small obhique tubercle on each side in front of the base of the hind legs and with a lateral fold on each side above their insertion, within which is a minute spiracle. The abdomen is 5 inches long, gradually narrowed, with the tip truncate; it is simple above, with the sides of the $2 \mathrm{nd}, 3 \mathrm{rd}, 4 \mathrm{th}$, 5th, and 6th segments rather dilated and deflexed; the extremity of the 6 th veutral segment is armed with a deflexed bifid point at the base of the oviduct which is 2 inches long. The fore legs are $7 \frac{1}{2}$ inches long; the thighs with two rows of spines; the tibiæ are scarcely spinose; the basal joint of the tarsi is as long as all the other joints together; the tarsi, as well as all the parts of the feet, are triquetrous, but the posterior thighs hare the upper angle truncated so that they have four rows of spines, as have also the tibix, but the spines of the latter are much smaller, except one spine on the upper margin near the base of the intermediate tibiæ, the basal joint of the tarsi in the four hind legs is not quite so long as the four following joints.

The insect above described is a female; I possess also another female, which I consider to belong to the same species, which is only $7 \frac{1}{2}$ inches long, and agrees with it in all its characters, except that the 6 th rentral segment has only a minute oval sulcated tubercle at its extremity. 


\section{FIGURE 2.}

BACTERIA VIRGEA. WEST.

Bacteria brunneo-fusca, tibiis anticis pallide fasciatis, corpore gracillimo lævissimo, femoribus spinosis, tibiis anticis valde elongatis haud spinulosis, 4 posticis spinulis minutis armatis, intermediis spinula majori marginis superi prope basin, abdominis segmento $7 \mathrm{mo}$ incrassato, ultimo fisso.

Bacteria reddish-brown, the tibiæ fasciated with paler colour, the body very sleuder aud smooth, the femora spined, the fore tibiæ very elongate without spinulæ, the four posterior tibiæ armed with minute spines ; the intermediate with a slightly larger spine on the upper margin near the base; the 7 th segment of the abdomen incrassated, the last one slit. (Male.)

Length of insect 6 inehes.

Inlabits Sylhet. In Coll. Westwood.

Observation.-The proportions and general appearance of this insect indicate that it is most probably the male of the preceding. It is on this account that $I$ have represented them both on one plate. 


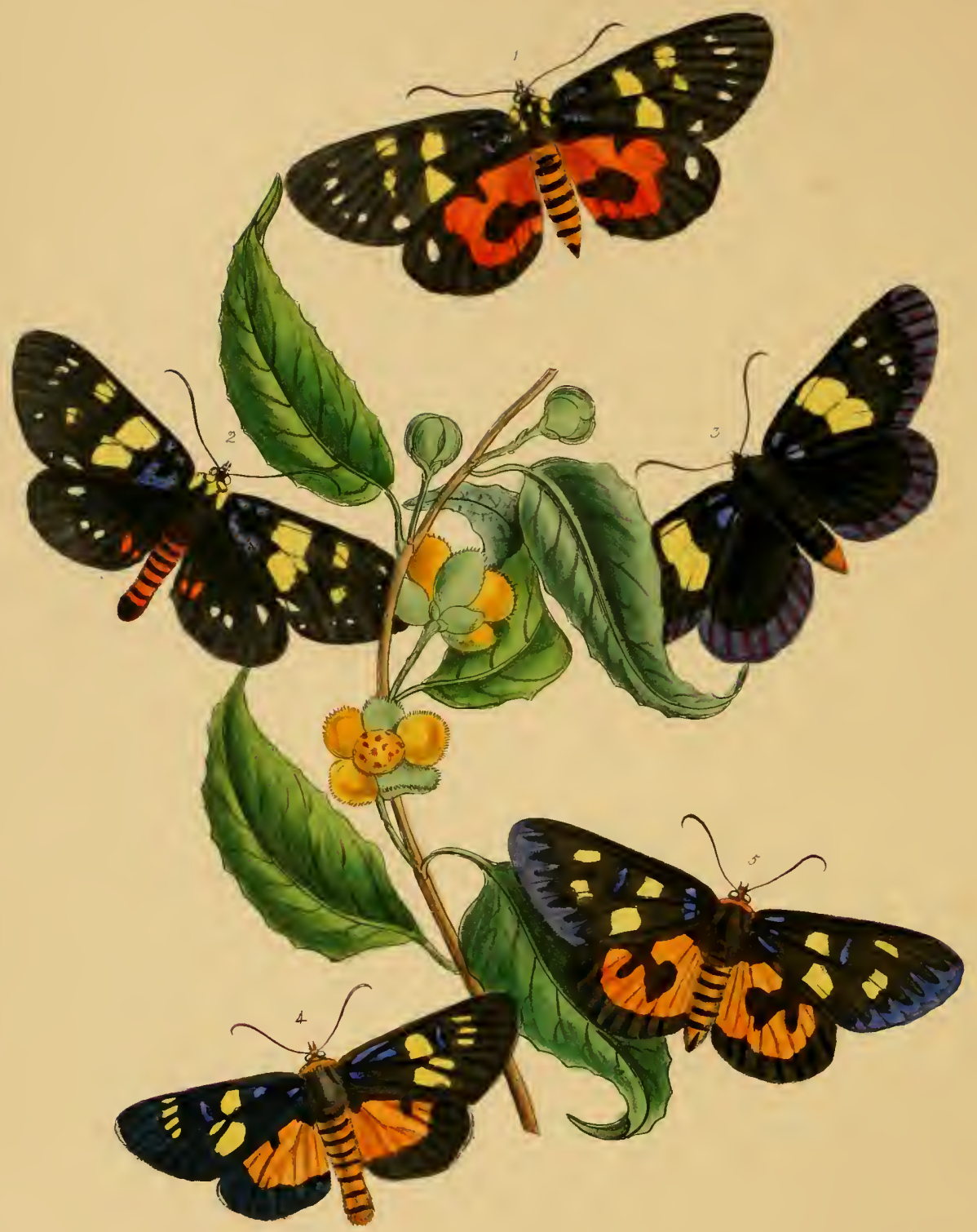





\section{PLATE XXXIII.}

\section{(ORDER-LEPIDOPTERA.}

\author{
$\rightarrow-$ \\ Section-Heterocera.
}

FIGURE 1.
FaMili-Agaristid.e.)

\section{eusemia maculatrix. Westw. (Nateralists' Libr. Exor. Moths, p. 88.)}

Eusemia alis anticis nigris basi cxerulco maculatis, puncto stramineo approximato maculis 4 discoidalibus, 2 majoribus, 2 minoribus, stramineis et pone has maculis 7 albis 6 ta minuta; posticis fulvo-rufis, basi costa macula angulata costali fimbria irregulari (in qua 1 vel 2 maculse albw) maculaque magna discoidali cum margine anab connexa, lineisque duabus ad fimbriam extensis, nigris : capite albo et parte antica thoracis stramineo-maculato; abdomine fulvo nigroque cingulato.

Eusemia with the four wings black, the base spotted with pale blue scales, and with an adjacent straw-coloured small patch, followed by 4 discoidal spots of the latter colour, two larger, and two smaller, the latter followed by a eurved row of 7 white spets, the 6 th being very small; hind wings rich orange red; the base and costa, the latter emitting an angulated spot, a broad, irregular, apical border (in whielt are one or two white spots) and a large discoidal spot connected with the anal margin and emitting two black lines which extend to the fimbria, all black; head spotted with white; and front of the thorax with straw-colour; abdomen orange; banded with black (female).

Expansion of the fore wings $3 \frac{1}{2}$ inches.

Inhabits Assam. In Coll. Westw, Conmunicated by Major Jenkins.

I have also received a closely allied, but rather smaller, species from Major Jenkins, in which the discoidal spots on the fore wings are yellower, forming two more evident fascix, and the fimbria of the hind wings has a regular series of submarginal white spots. For this species the name of Eusemia fasciatrix may be proposed.

\section{FIGURE 2.}

\section{EUSEMIA BELLATRIX. Westw.}

Eusemia alis anticis nigris, basi maculis majoribus palbide cæruleis, fascia lata ante, maculisque duahus mineribus pone medium sulphureis punetisque uonnulbs albis inter has et marginem apicalem; alis posticis nigris maculis tribus albis pene medium alterisque duabus sanguineis ad angulum analem, capite albo thoraceque antice sulphureomaculatis; abdomine nigro sanguineo fasciato.

Fusemia with the fore wings black witl several large pale blue spots near the base, followed by a broad sulphur yellow fascia before, and two spots of the same colour beyond the middle; between the latter and the apical margin are several small white spots, and a short pale blue dash on the inner margin; hind wings black, with 3 white spots beyond the middle and two blood-coloured spots at the anal angle; head spotted with white, front of the thorax with sulphur; abdomen black, with blood-red fascixe.

Expansion of the fore wings nearly $3 \frac{1}{4}$ inches.

Inhabits Assam. Communicated by Major Jenkins.

\section{FIGURE 3.}

\section{EUSEMIIA VICTRIX. WESTW,}

Eusemia alis anticis nigris macula transversali basali, fimbriaque dentata marginis apicalis purpureis, fascia lata straminea ante medium maculisque tribus parvis albis pone medium; alis pesticis nigris, fimbria lata purpurea; corpore nigro, femoribus auticis segmentoque apicali abdominis fulvis.

Eusemia with the fore wings black, with a transverse spot near the base, and a rather broad dentate border along the apical margin of rich purple; a bread straw-coloured fascia before the middle and three small white spots beyond; hind wings black with a purple apical border ; body black, fore thighs and apical segment of the abdomen fulvous.

Expansion of the fore wings $3 \frac{1}{4}$ inches.

Inhabits Assam. In the Collection of the British Museum, and R. H. Solly, Esq. 
FIGURE 4.

EUSEMIA AMATRIX. WESTW.

Eusemia ahis anticis nigris certo situ purpureo, maculisque cæruleis ante et pone medium tinctis costa tenui fulva, maculis tribus majoribus stramineis prope medium, maculisque 4 parvis ovalibus albis inter medium et apicem, alis posticis læte fulvis basi, macula prope costam margineque lato apicali nigris ; capite, collari, pedibusque fulvis, thorace nigro, abdomine fulvo migro-fasciato, cilia ad angulum apicalem alba.

Eusemia with the fore wings black, glossed in eertain points of view, with purple, and with several blue patches before and beyond the middle; three large straw-coloured spots near the middle of the wing, aud between them and the apex is a row of four small oval white spots; hind wings rich fulvous; the base, a spot near the costa resting on a black longitudinal line, and a rather broad fimbria of black, glossed with purple; head, collar, and legs fulvous ; thorax black ; abdomen fulvous, with black rings ; cilia of all the wings near the apical angle white.

Expansion of the fore wings $2 \frac{4}{5}$ inches.

Inhabits Assam. Communicated by Major Jenkins.

FIGURE 5 .

\section{EUSEMIA DENTATRIX. Westw.}

Eusemia alis anticis nigris, maculis nonnullis ad basin alarum margineque apicali acute dentata ceruleis, maculis duabus majoribus quadratis ante medium alterisque duabus albis pone medium; alis posticis fulvis, basi, macula magna discoidali postice dentata et cum costa connexa nargineque postico late nigris ; capite, collari, femoribusque anticis fulvis ; thorace nigro, abdomine fulvo nigro fasciato.

Eusemia with the fore wings black, the base marked with several blue spots, and the apical margin of the same colour, and very acutely toothed (the blue colour ascending along the veins) two large, nearly square, straw-coloured spots before the middle, and two smaller white ones beyond the middle, which is transversely glossed with blue ; hind wings fulvous, the base, a large discoidal spot posteriorly dentate, and connected with the costa, and a moderately broad apical margin of black; head, collar, and fore thigbs fulvous, thorax black ; abdomen fulvous, banded with black.

Expansion of the fore wings $3 \frac{x}{5}$ inches.

Inhabits Assam. Communicated by Major Jenkins.

"The Genus Eusemia was proposed by Dalman, in his Monograph on Castuia, for Bombyx lectrix (Cramer, Donov. Ins. China, pl. 43, fig. 2.) He cousidered it as very nearly allied to Agarista, and such is certainly the case since they agree in the structure of the antennæ, palpi, spiral tongue, veins, bridle, and general colouriug of the wing. The principal difference is in the structure of the fore legs, which are sufficiently unlike to warrant their separation. The fore thighs (as they appear in E. maculatrix) have not the strong brush of hairs which is so conspicuous in Agarista, and in fact are glabrous. The tarsi are very long, and become gradually more slender to the tips, each being furnished with one rery long and slender unguis, the other being short and bifid. The four terminal joints of the tarsi are almost denuded, except that there exists a row of very delicate short setæ, and another of slender short incurved spinula." J. O. W. in Naturalists' Libr. Exot. Moths, p. 87.

The plant represented in the plate is the Nepalese Sphœrostema propiuquum, of Blume. 


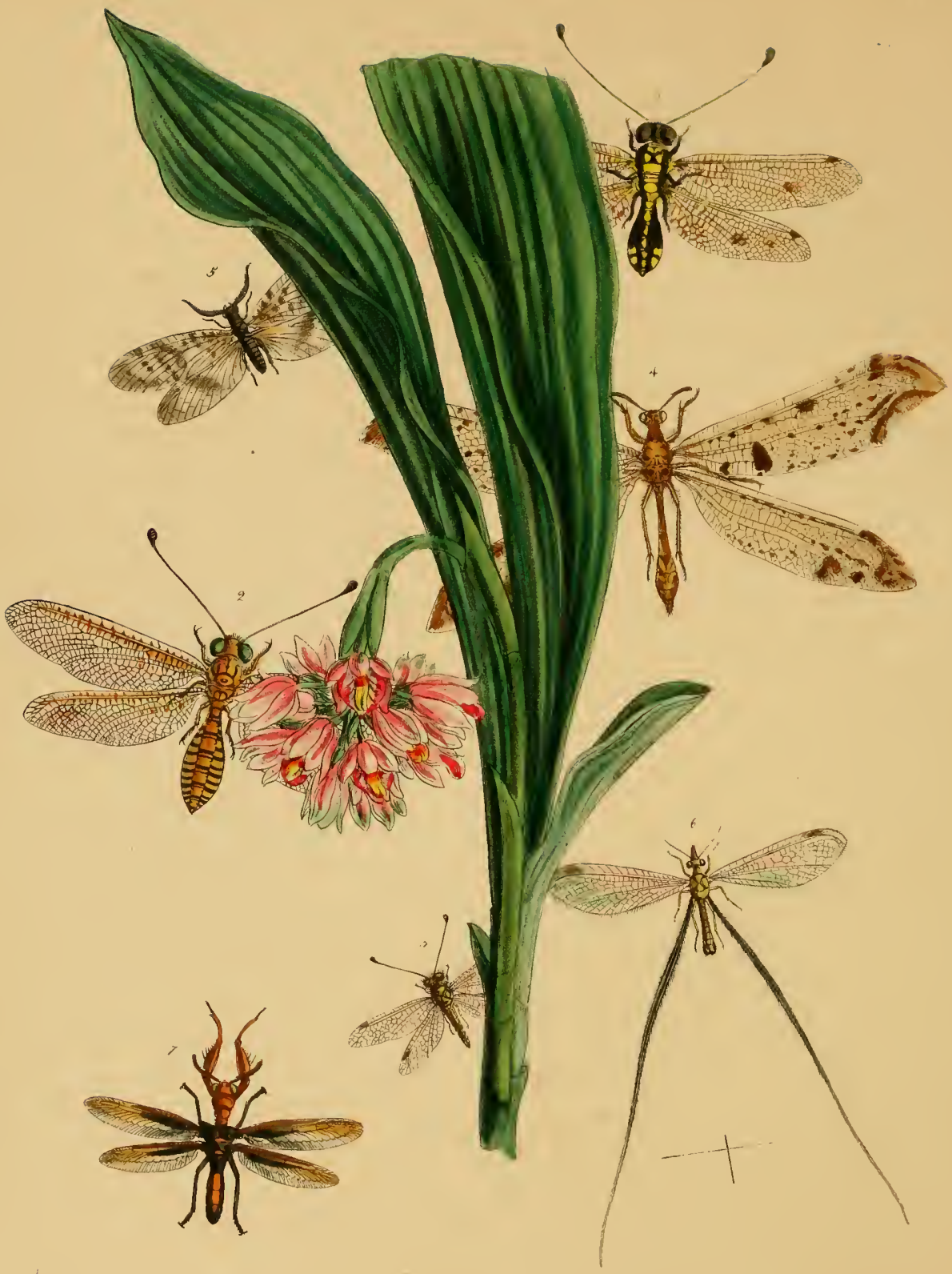


. 


\title{
PLATE XXXIV.
}

\section{(ORDER-NEURoptera. Section-Sebnechomormotica. Westw. Sub-Section-Planipennes.) \\ FIGURF 1. \\ ASCALAPIIUS (OGCOGASTER) TESSELLATUS. WESTW.}

\begin{abstract}
Ascalaphus niger, facie fusca, antennis fulvis apice magno pyriformi nigro, oculorum parte supera unferî multo majori, eapite pone oculos fulvo, collare fascia tenui, mesonoto maculis 5 , metanoto 3 transversis, flavis ; abdomine nigro dilatato, dorso serie macularum, lateribusque versus basin et apicem maculis flavis; alis subfulvescentibus stigmate nigro, veuis versus basin fusco tinctis maculaque parva discoidali fusca notatis, abdomine ut videtur baud appendieulato.

A scalaphus black with the face brown, slightly hirsute, antenne fulvous, the apex large, black, and pear-shaped, the upper division of the eyes nuch larger than the lower, head yellow behind the eyes, the collar witl a sbort, transverse line; mesonotum with five spots, metanotum with three, all yellow; abdomen black, much dilated, the back with a series of diamond-sliaped spots (separated by thin trausverse lines), and the sides at the base and apex spotted with yellow; wings sbghtly fulrous-brown, the stigma black, the veins near the base stained with brown, and with a small browu discoidal spot, the abdomen apparently without anal appendages.

Expansion of the fore wings 23 inches. Inhabits the East Indies. In the Collection of W. W. Saunders, Esq.
\end{abstract}

FIGURE 2.

ASCALAPHUS (OGCOGASTER) SEGMENTATOR. WESTW.

Ascalaphus flavus oculis antennisque fuscis harum apice fere rotundato, facie vix pilosa ; thorace surra lineis longitudinalibus et transrersis nigris notato; abdominis segmentis dorso fascia tenui basali alteraque subapicali latiori nigris, latcribus dilatatis nigro striatis ; pedibus fulvis tarsis fuscis; alis subflavescentibus stigmate lineaque subcostali, basique flavis, venis transversis costalibus subcostalibus et basalibus fusco tinetis.

Ascalaphus yellow, the eyes and antennce brown, the tips of the latter black and nearly round, face scarcely pilose, upper side of the thorax with slender longitudinal and transverse black lines, dorsal segments of the abdomen marked with a slender basal and a broader subapical transverse black stroke; the sides dilated, and transversely striped with black; legs fulvous, tarsi brown; wings slightly yellowisb, with the stigma, a subcostal line and the base yellow, the costal and subcostal transverse veins, and those at the base of the wings, tinged with brown.

Expansion of the fore wings, 3 inches. Inhabits the East Indies. In the Collection of IV. W. Saunders, Esq., and my own.

\section{FIGURE 3.}

\section{ASCALAPHUS (BUBO) CANIFRONS. WeSTW.}

Ascalaphus fuscus, facie dense cano-hirtus, ore subfulvo, capite postice fulvo fusco-variegato, thorace etiam fulvo vario; abdomine supra fulvo vitta tenui dorsali nigra, antennis fuscis apice dilatato subtriangulari ; alis parum venosis pellucidis byalinis stigmate parvo subfusco, pedibus fulvis basi femorum obscuro.

* As the only Eastern species of Ascalaplus hitherto described is the A. javanus from Java, the following descriptions of several new Indian species are bere introduced :-

ASCALAPHUS (Ogeogaster ?) dentifer, Westw. Niger capite pone oculos luteo; thorace vitta longitudinali subinterrupta flava, mesoscutelli marginibus, punctoque inter hoe et basin alarum flavis, abdomine nigro vitta longitudinali dorsali interrupta margineque postico segmentorum flavis; antennis pedibusque nigris, calearibus posticis brevibus; alis subfusco-hyalinis, basi extremo flavis, stigmate nigro, posticis pone stigma fusco magis tinetis, anticis prope basin marginis postici, dente parvo instruetis.

Expansion of the fore mings 3 inches. Inhabits the East Indies. Col. Hearsey.

ASCA LAPHUS (Ogcogaster?) angulatus, Westw. Niger capite pone oculos luteo, antennis valde elongatis pallide fuscis apice nigricantibus, facie, ore, pedibusque nigris, thoracis dorso flavo lateribus antice nigris, mesoscutello vittis duabus obliquis nigris, abdominis dorso fulvo segmentis ante apicem fascia tenui nigra, margine postico pallidis, apice obscuriori ; alis subhyalinis stigmate fusco ; basi extremo subfulvis ; anticis prope basin marginis postici angulatis.

Expansion of the fore wings 3 inches. Inhabits Assam. Major Jenkins.

ASCALAPHUS (Haploglenius) obscurus. Fusco-niger, oculis brunneis antennis apice pallidis, thoracis dorso concolori obscuro, abdominis segmentis 2 et 3 strigis duabus obliquis velutino-nigris; alis subparallelis subangustis hyalinis venis stigmateque nigricantibus ; anticis versus basin marginis postici vix angulatis, margine ipso anguli parum incrassato, unguibus tarsorum longioribus curratis.

Expansion of the fore wings 21 inches. Inhabits the East Indies. Col, Hearsey. 
Ascalaphus brown, the face densely clothed with grey hairs, the mouth rather fulvous; head behind fulrous, varied with brown marks; abdomen above fulvous, with a slender dorsal black streak; antennæe brown, the tip dilated and subtriangular, the wings with comparatively few reins, pellucid and hyaline, the stigma small and palebrown, legs fulvous, the base of the thighs dark coloured.

Expansion of the fore wings $1 \frac{1}{4}$ inch. Inhabits the East Indies. In the Collection of W. W. Saunders, Esq.

\section{FIGURE 4.}

\section{MYRMELEON SINGULARE. WESTW.}

Myrmeleon albidum brunneo fuscoque variegatum, capite parvo, fusco irrorato ; antennis sensim incrassatis, collari elongato, postice fusco maculato, thoracis dorso fusco maculato, maculis duabus obscurioribus inter basin alarum posticarum; abdominis segmentis albido oblique vittatis ; pedibus albidis, calcaribus elongatis curvatis ; alis elongatis anticis apice dilatatis subfaleatis ; posticis apice acutis ; omnibus brunneo-fusco maculatis; alis in foemina nitidissimis.

Myrmelon buff-coloured, varied with brunneous and brown; the head small and marked with numerous minute brown dots; the antennze gradually thickened; the collar elongated, marked near the hind margin with brown spots, the back of the thorax spotted with brown, with two darker spots between the base of the hind wings; segments of the abdomen obliquely streaked with pale buff lines, legs pale buff, spurs elongated and curved ; wings elongated, the fore wings dilated at the apex and subfalcate; the hind ones acute at the tips, all spotted with brunneous brown. Wings in the female very glossy.

Expansion of the fore wings 4 inches. Inhabits the East Indies. In the Collections of the Linnæan Society and Capt. Boys.

\section{FIGURE 5.}

CHAULIODES SUBFASCIATUS. WEST.

Chauliodes nigricans ore fulvo, antennis pectinatis nigricantibus, alis obscure hyalinis basi extremo fulvis, anticis dimidio basali maculis rotundatis, tune fascia obliqu submediana, maculis nonnullis rotundatis connexa, apiceque fuscescentibus, alis posticis fascia obliqua media apiceque etiam fuscescentibus.

Chauhodes blackish, with the mouth fulvous; the antennæ pectinated and blackish, the wings obscurely transparent, the extreme base fulvous, the basal half of the fore wings marked with a number of round dusky spots, followed by an oblique fascia nearly across the middle of the wing connected with several adjacent dusky spots, the apex also dusky ; hind wings with an oblique central fascia, and the apex also dusky.

Expansion of the fore wings $1 \frac{5}{6}$ inch. Inhabits Sylhet. In the Collection of W. W. Saunders, Esq.

Observation.-The other Eastern species allied to the genus here represented are, Chauliodes (Hermes) maculipennis Gray in Griff. A. King. pl. 72, fig. 1, from India; Neuromus (Hermes) testaceus Rambur, Pl. 10, fig. 1, from Java; and Neuromus ruficollis Ramb. from Batavia.

\section{FIGURE 6.}

\section{NEMIOPTERA FILIPENNIS. WESTW.}

Nemoptera subfulva anteunis fuscis, alis anticis hyalinis stigmate fusco, alis posticis longissimis filiformibus limidio basali fusco, apice albo.

Nemoptera duli fulvous-coloured, antenne brown, fore wings liyaline iridescent, with a pale brown stigma, hind wings very long, thread-like, the basal half brown, the extremity white.

Expansion of the fore wings nearly 1 incl.. Length of the hind wings $\mathrm{J}_{\frac{1}{4}}$ inch.

Inhabits Central Iudia. In the Collections of Col. Hearsey and Mr. Hope.

\section{FIGURE $\tau$.}

\section{MANTISPA NODOSA. WESTW.}

Mantispa nigra, capite antennis prothorace et pedibns anticis ferrugineis, abdominis dorso in medio obscure fulvo, ahis subhyalinis dimidio costali fulvo, basi fusco strigaque obliqua ante medium fusco, in posticis fere obliteratis ; prothorace brevi nodoso, antennis 48-articulatis.

Mantispa olsscure black; the head, antenne, prothorax, and fore legs ferruginous ; the back of the abdomen in the middle obscurely fulvous; the wings somewhat hyaline, the costal half fulvous, the base brown and with an obhique band of the same colour before the middle of the wing, which is nearly obliterated in the hind wings; prothorax short and nodose, antennæe with 48 joints.

Expansion of the fore wings nearly 2 inches. Inhabits Assam. Dr. Cantor. In Mus. Hope.

The plant represented in Plate 34 is the Orchidaceous Geodorum fucatum from Ceylou. 


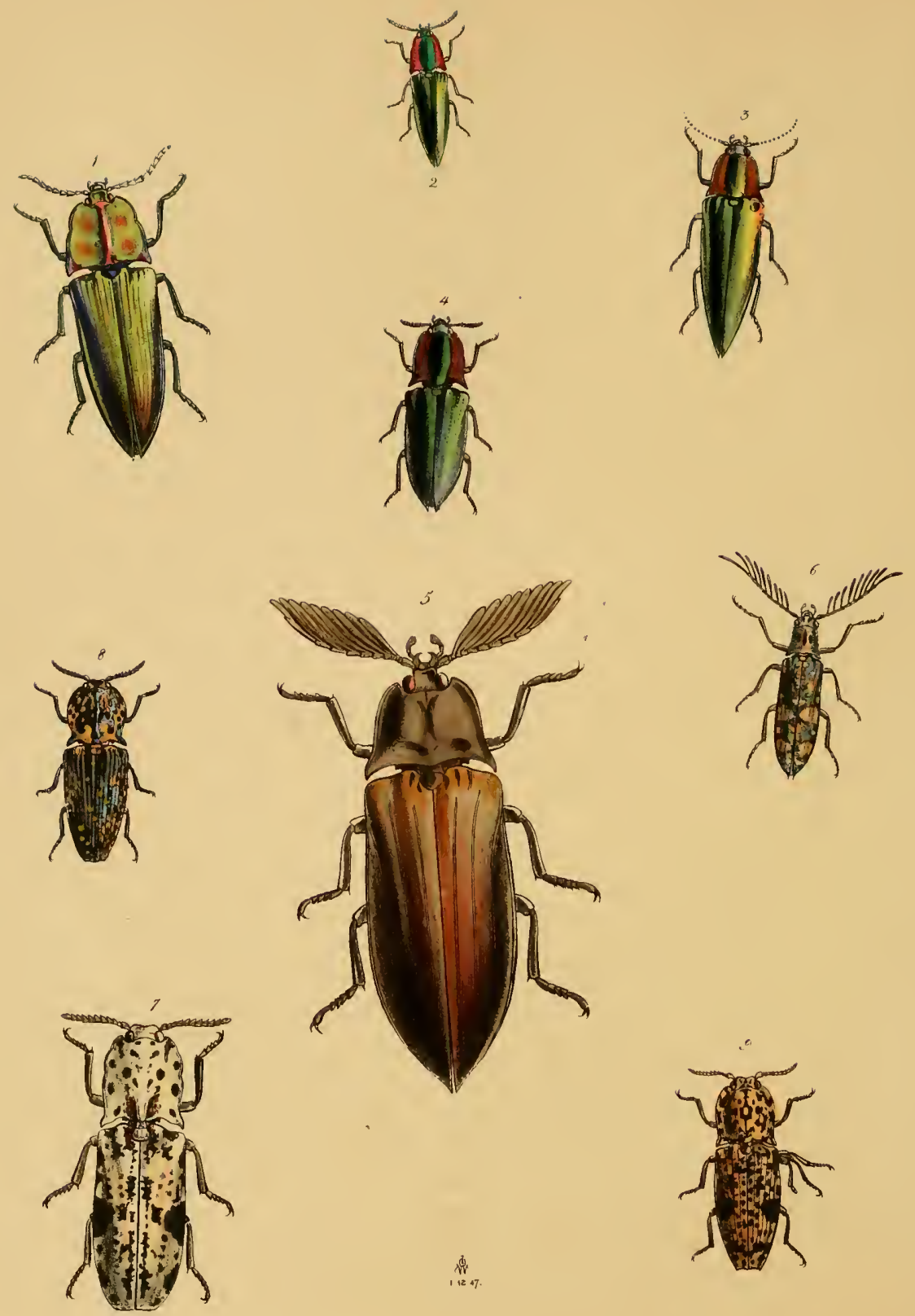



\section{PLATE XXNV.}

\section{(ORDER-COLEOPTERa. Section-Pextamem. Family-Elaterid.e.) \\ FIGURE 1.-CAMPSOSTERNUS TEMPLETONIJ. WESTW.}

Campsosteruus viridi-reneus; pronoto lateribus marginatis cyancis ante medium parum sinuatis, disco depresso, euprescenti carina media longitudinali elevata late purpurea nitidissima, angulis posticis etiam purpureis, elytris subconvexis, postice magis cupreis, sutura marginibusque lateralibus cyanescentibus, disco sub lente granulosis, striisque novem in singulo fere obliteratis ; corpore subtus cyaneo-purpurascenti, latcrilus thoracis et metasterni abdomineque magis cupreis, antennis pedibusque chalybseis.

Campsosternus brassy green; the sides of the pronotum margined and cyancous, and slightly sinuated hefore the middle, with a small excavation on each side beyond the middle, the disk depressed and coppery, having a rather raised longitudinal central carina of rich glossy purple, the hind angles also purple; the elytra rather convex, rather more coppery beyond the middle, the suture and lateral margins cyancous, the disk seen through a lens is very finely granulose, and each elytron lias nine vcry fine strixe scarcely visille ; the body beneath is purple-cyaneous, with the sides of the thorax and metasternum and the ahdomen more coppery; the autenux and legs chalybeous.

Length of the insect 185 inch. Inlabits Ceylon. In the Collection of R. Templeton, Esq.

FIGURE 2.-CAMIPSOSTERNUS DOHRNII. WEST.

Campsosternus æneus, elytris magis auratis capite inter oculos bicanaliculato, antennis brevioribus cyaneis ; pronoto convexo glaberrimo lateribus ante medium vix sinuatis rufo-purpureis, disco ante margincm posticum bi-impresso, elytris glabris sub lente punctis minutis impressis et ad basin stris impressis notatis ; corpore subtus concolori, pedibus nigro-æneis.

Campsosternus brassy with the elytra more golden coloured; the head is marked with two longitudinal impressions between the eyes; the anteunze rather short and cyaneous ; the pronotum convex, and very glossy; the sides before the middle are scarccly sinuated, and are purphsh-red; the brassy disk has two impressious preceding the posterior margin ; the elytra are glossy, and impressed with minute punctures, visible only under a lens; the base is marked with several short deeper longitudinal strix ; the body is coloured beneath as above; the legs are brassy black.

Length of the insect nearly 1 inch. Inhabits Assam. Commumicated by Major Jenkins. Named in honour of the President of the Entomological Society of Stettin.

\section{FIGURE 3.-CAMPSOSTERNUS STEPHENSII. HOPE. (in ZooL. MIsc., p. 25.)}

Campsosternus postice valde acuminatus, supra viridi-auratus lævis, capite punctato, facie impressione ovali profunda, pronoto impressionibus duabus obliquis prope medium marginis postici, lateribus integris vitta lata ferruginca, margine ipso elevato æneo, subtus aurato-æneus, nitidissimus, prothoracis lateribus ferrugineo-vittatis, pedibus aureo-ieneis.

Campsosternus very much attenuated posteriorly, abore golden green, smooth, the bead punctured, the face witl a deep oval impression; the pronotum with the sides entire, anil with two oblique impressions near the middle of the posterior margin, the sides with a broad ferruginous band, the margin itself being elevated and brassy ; beneath brassy gold-coloured and rery glossy; siles of the prothorax broadly banded with ferruginous ; the legs brassy-golden. Elytra deeply impressed at the base.

Length, of the insect nearly $]_{\frac{1}{2}}^{2}$ inch. Inlahits Nepaul. Gen. Hardwicke. In the Collection of the British Museum.

FIGURE 4.-CAMPSOSTERNUS HOPEI. WESTW.

Campsosternus latus nitidissimus, supra cyaneo-viridis elytris basi parum punctato-striatis ; capite nigro occipite concavo ; lateribus prothoracis purpureo late rittatis, marginatis integris; corpore subtus cyanco nitidissimo lateribus thoracis et abdominis purpureo-tinetis; pedibus cyaneis, femoribus castaneo-rufis.

Campsosternus broad, convex, and rery glossy; above blue-green, elytra at the base slightly punctate-striate, the head black with the crown coneave; the sides of the prothorax broadly banded with reddisli-purple margined and entire; body beneath cyaneous, very glossy, the sides of the thorax and abdomen tinged with purple; legs cyaneous, thighs chesnut-red.

Length of the insect 1 inch. Inhabits Tennasserim. In the British Museum.

Figure 5.-OXYNoptertS CUMINGil. Hope. (In Proc. Zool. Soc., 1842, p. 7i.)

Oxynopterus fusco-nigricans, capite et pronoto pubescentia brevi grisea indutis, anteunis ferrugineis capitis clypeo rotundato atro, medio disci subsulcato; prothorace fusco marginibus elevatis, angulis anticis parum productis 
posticis acutis et extus divergentibus ; scutello postice rotundato atro ; elytris acuminatis fusco-flavis, hineis tribus parum elevatis, corpore infra atropiceo, fenoribus concoloribus, mesosterno fortiter excavato, cornu prosterni ad pedes medios extenso. Fomina major antennis simplicibus.

Oxynopterus blackish-brown, head and prothorax clothed with short grey pubescence, antennæ ferruginous, clypeus of the head rounded, black ; the middle of the dise subsuleated ; prothorax brown, with the lateral margins elevated, the anterior angles somewhat produced, the hind ones acute and extended outwardly, the scutellum rounded behind, and black, the elytra acuminate at the tips, fulvous-brown, with three slightly elevated lines, the body beneath pitchy-brown, the thighs of the same colour, the mesosternum strongly excavated, the prosternal spine extending to the middle feet. The female is about a quarter of an inch larger, and has simple antennæ.

Length of the insect about 3 inches. Inhabits the Pliilippine Islands. Mr. Cuming. In the British Museum.

\section{FIGURE 6.-PECTOCERA MELLII. Hope, (Op. Crt. p. 79.)}

Pectocera flavo-fusca, griseo variegatus; antennis pectinatis, prothorace subtomentoso angulis posticis acutis, elytris jostice valde acuminatis; pedibus flavo-fuscis et pubescentibus.

Pectocera yellowish-brown, variegated with grey, the antennse pectinated (the pectinations not so long as in $\mathbf{P}$. Cantori) protlicrax somewhat tomentose, posterior angles acute, elytra posteriorly very much acuminated; legs yellowislı-brown and pubescent.

Length of the insect about 1 inch. Inhabits Simlah in Thibet. In the Collection of A. Melly, Esq.

\section{FIGURE 7.-ALAUS MCERENS. WESTw.}

Alaus supra lacteo-griseus, griseo nebulosus nigroque maculatus; occipite plano; pronoto oblongo convexo lateribus sinuatis, margine postico in medio carina elevata instructo, prothoracis angulis anticis, maculis lateralibus duolusque discoidalibus nigris; elytrorum regione scutellari, humeris, maculis lateralibus (duabus in medio majoribus) vigris, regione suturali nigro tessellato apicibus subrotundatis; antemis pedibusque fuscis ; corpore subtus luteo-fusco, fusco tessellato.

Alaus, above cream-coloured, mixed with grey, and varied with grey elouds and black spots; forehead flat, pronotum oblong, convex, the sides in the middle sinuated; the hind margin with a raised space in front of the scutellum; the anterior angles and lateral spots, as well as two nore distinct ones on the dise, black; the elytra near the scutellum, the shoulders, and lateral spots (two of which are larger than the rest) black ; the space near the suture tessellated with black, the tips rather rounded; antenuæe and legs browa, body beneath luteous-brown, tessellated with dark brown.

Length of the insect nearly 2 inches. Inhabits India. In the British Museum.

\section{FIGURE 8.-ALAUS SCULPTUS. IWESTW.}

Alaus niger, pubescentia lutea maculatus, punctisque atris velutinis varius, capite puctato, inter oculos profunde impresso, prothorace sulurotundato supra valde convexo variolnso, rivulis impressionibusque numerosis punctatis, interstitiis glabris lateribus marginis postici exeavatis; elytris punctato-striatis, basi prope scutellum et inter humeros profunde impressis; apicibus truncatis ; copore subtus luteo magis tessellato.

Alaus black, spotted with luteous pubeseence, and varied with black velvet-hike patches; head punctured, deeply impressed between the eyes; prothorax nearly rounded (much coustricted before the linder angles) very convex, surface irregular, with channels and numerous impressed spots, which are thickly punctured, leaving the interstices glabrous; the sides of the hind margin excavated, the elytra punctate-striate, the base near the scutellum and between the shoulders deeply impressed; the tips truncated, body beneath more thickly tessellated witlı luteous.

Length of the insect nearly $1 \frac{1}{4}$ inch. Inhabits the Kasyah Hills of India. In the Collection of the Rev. F. W. Hope.

\section{FIGURE 9.-ALAUS SORDIDUS. WESTW.}

Alaus opacus pubescens, sordide albidus maculis numerosis nigris, fascia media interrupta elytrorum alteraque subapicali in medio angulata uigris; prothorace subquadrato supra convexo; utrinque versus angulos anticos $W$ nigra, mediqque $\square$ nigra notato ; elytris punctato-striatis, basi subimpressis apicibusque truncatis ; corpore subtus sordide albido opaco abdominis lateribus nigro maculatis.

Alaus opaque pubescent, dirty buff-coloured, varied with numerous black spots; a broad interrupted fascia in the middle of the elytra, and a narrower subapical one angulated at the suture, all black; the prothorax is nearly square, convex, and marked near each of the anterior angles with a black $W$, and in the middle with a black $\square$; elytra punctate striate, slightly impressed at the base, and truucate at the tips; body beneath dirty buff opaque ; the sides of the abdomen with small black spots. The specimen figured is a singular monstrosity; the middle leg on the right side having the coxa and trochanter of the normal form, followed by three femora conjoined together at the base, each with its perfect tibia, and with one imperfect and two perfect tarsi.

Length of the insect $1 \frac{3}{4}$ inch. Inlabits the Island of Ceylon. In the Collection of R. Templeton, Esq. 



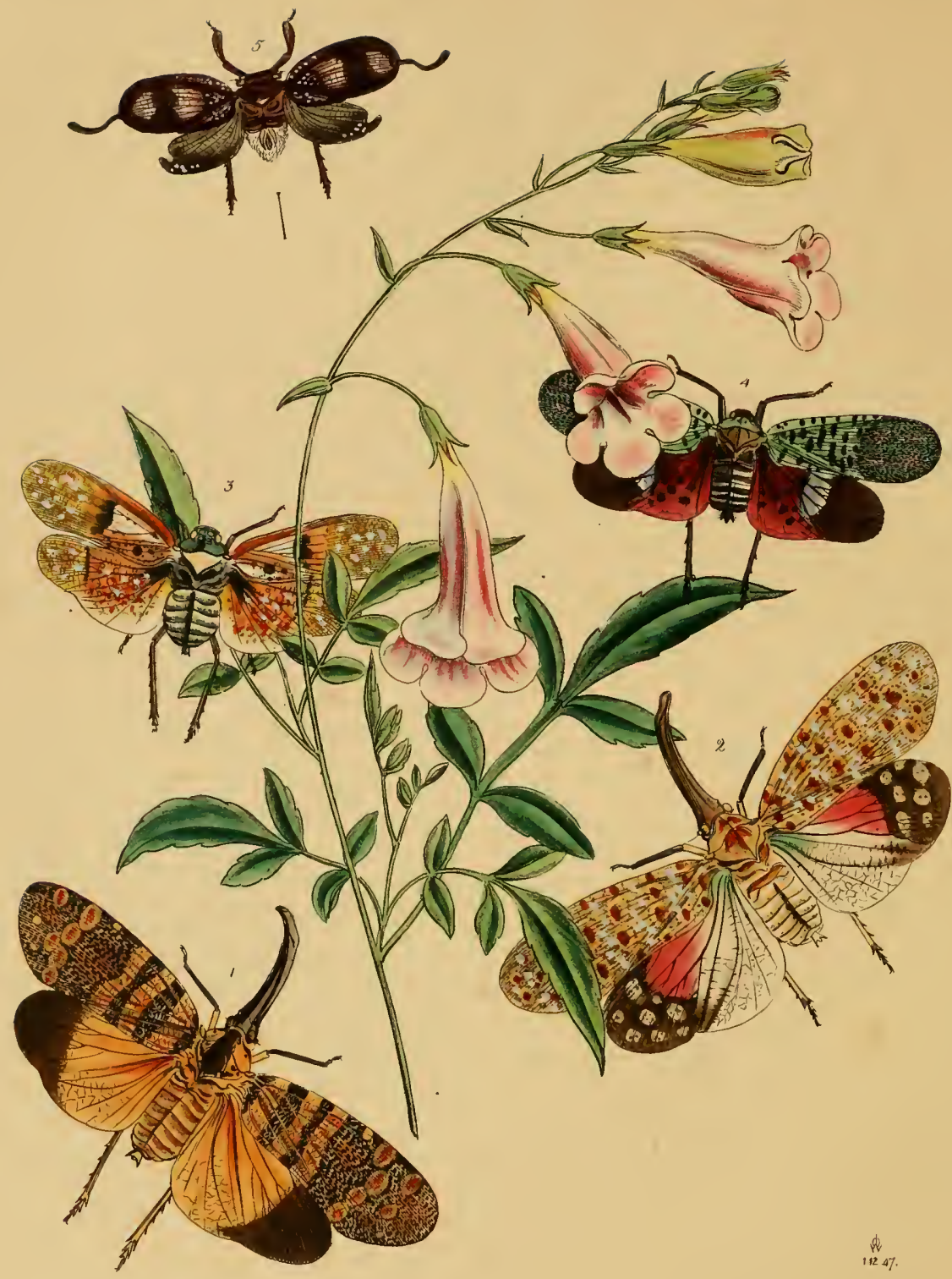




\title{
PLATE XXXVI.
}

(ORDER-HOMOPTERA.

\author{
Section-Trimera. \\ FIGURE 1.
}

FULGORA (IIOTINA) SPINOLE. WEStw. (IN AN. NAT. IItsT., April, 1842.)

\begin{abstract}
Fulgora rostro corporis longitudine alsecndente supra nigro, subtus luteo; corpore fulvo, pronoti margine antico et in medio, mesonoto plaga lata media punctis duobus strigisque duabus obliquis lateralibus nigris; alis anticis fuscis venis fulvis, ante medium fasciis tribus rectis transversis, pallido fulvis, maculisque 6 aut 7 subapicalibus (quarum nonnullæe fasciam macularem formant); alis posticis fulvis apicibus nigris.

Fulgora with the rostrum as long as the body, ascending at the tip, black above, lutcous beneath, body fulvous, the pronotum with the anterior margin and the middle, and the mesonotum with a broad central pateh, two dots and two oblique lateral streaks, all black; fore wings brown with fulvous veins; basal half traversed by three straight transverse fascice of a pale fulvous colour, and 6 or 7 subapical circular spots, (some of which form a macular fascia) of the same colour; hind wings fulvous with the tips broadly black.
\end{abstract}

Expansion of the fore wings $3 \frac{1}{4}$ inches.

luluabits IIysore and Assam. In the Collections of the Rev. F. W. Hope and Westwood.

\section{FIGURE 2.}

FUlgora (Hotina) oculata. Varietr. Westw. (In Linn. Trans. 18, p. 142, pl. 12, f. 5.)

(Variety. Fulgora Sunocellata Guérin, Rev. Zool. ani Ins., in Voy. Delessert, pl, 16, f. 1.)

Fulgora rostro corporis longitudine adscendente brunneo; corpore grisco-luteo, albo farinoso, hemelytris griseofulvis, maculis ocellatis circitcr $24-30$ fulvis, albido-annulatis; alis posticis albo farinosis, basi pallide virescentibus medio costæe plaga magna rosea et pone hane fusco plus minusve tinctis (interdum ut in figura preesenti omnino fusco, maculis pallidioribus rotundatis) pedibus luteis tibiis tarsisque 4 anticis cum tarsis posticis nigris.

Fulgora with the rostrum as long as the body, ascending at the tip, brunneous; body greyish luteaus, powdered with white; hemelytra greyish-fulvous, each with from 24 to 30 fulvous ocellatcd spots, encircled with buff; hind wings powdered with white, the base pale green, the middle of the costa marked with a large rosy patels and followed by a brown streak which is occasionally (as in the specimen here figured) extended over the whole apex of the wing, which is in such case marked with several paler spots; legs luteous, the four anterior tibie and tarsi and the two hind tarsi black.

Expansion of the fore wings $2 \frac{1}{2}$ to $3 \frac{1}{2}$ inches.

Inhabits Malabar (Guérin), Prince of Wales's Island (Dr. Cantor). In the Collection of Rev. F. W. Hopo.

ObSERvations. - I am indebted to M. Dalen, of Rotterdam, for a drawing of another remarkably fine variety of this species, executed by Col. Ver Huell, in which the spots of the fore wings are confluent, and of a rosy colour; the green at the base of the hind wings not being represented.

M. Guérin has shortly characterised another new species of Fulgora from Java, in the 'Annales' of the French Entomological Society, 1845, p. xcvi., under the name of F. cyanirostris. This is still unfigured. Another new species (unnamed and unfigured) also from Java, is noticed in the same volume, p. xcriii. And I have seen at the British Museum the drawing of another beautiful species from Bormeo, which is intended for publication.

\section{FIGURE 3.}

\section{APH ENA SCUTELLARIS. White. (IN AN. NAT. Hist., 1846.)}

Aphæna viridi-fusca; occipite excavato punctis duobus farinosis intra oculos; prothorace carina media elevata; scutello albo-farinoso, metanoto nigricanti, abdominis marginibus segmentorum viridi luteis, basi albo farinosis; alis anticis dimidio basali ferrugineo disco albo farinoso, medio fascia irregulari punctisque nonnullis posticis nigris; dimidio apicali lutescenti albido vario, alis posticis fulvo-rufis albo-maculatis, basi nigris, apicibus lutescentibus, angulo anali albido; corpore subtus cum pedibus piceis. 
Aphena greenish-brown, the crown of the head excavated and marked with two whitish powdery spots between the eyes; the prothorax with an elevated carina down the middle, the scutellum powdered with white, the metathorax blackish; the margins of the abdominal segments luteous-green, the base powdered with white; the basal half of the tegmina ferruginous, the disc powdered with white, and with an irregular black fascia in the centre, and some blackish spots near the hind margiu, the apical portion horn-coloured varied with buff, hind wings orange-red spotted with white, the base black, the apical portion horn-coloured, and the anal angle buff; body beneatl and legs pitchy.

Expansion of the fore wings $2 \frac{1}{2}$ inches.

Inlabits Java. In Mus. Westwood. Communicated by M. Serville, from the Collection of Latreille.

The specimens described by Mr. White, in the British Museum Collection, are from Borneo, and vary in the green colour of the basal portion of the costa and the base of the fore wings.

\section{FIGURE 4.}

\section{APHANA IMPERIALIS. White (In Ans. Nat. Hist., 1846.)}

A phæna piceo-fusca facie et mesonoto brunneis, abdomine nigro albo-farinoso ; tegminibus viridi-opacis apicibus late viridi-fuscis, parte viridi maculis circiter 25 nigris ( 8 costalibus); alis posticis dimidio basali incarnatis maculis 9 nigris; apicibus late nigris macula magna ovali viridi-cærulea a basi separatis, pedibus piceo-fuscis.

Apliena pitchy-brown, the face and seutellum brunneous, the abdomen black, powdered with white; the tegmiua are opaque green, with the apices broadly greenish-brown; the basal green part with about 25 black spots (8 of which are costal); hind wings with the basal half dark scarlet with about 9 black spots, the apex broadly black, which is separated from the base by a large oval blue green spot arising from the costa, legs pitchy-brown.

Expansion of the tegmina $2 \frac{1}{2}$ inches.

Iuhabits Sylhet. In Mus. Britann., Saunders and Westwood. Communicated by W. W. Saunders, Esil.

\section{FIGURE 5.}

\section{ANCYRA APPENDICUlatA. White. (In Ann. Nat. Hist., Jan. 1845.)}

Piceo-nigra, facie, occipite et pronoto griseo transverse striatis; metanoto sanguineo maculis duabus nigris; abdomine nigro apice albo-farinoso ; corpore subtus pedibusque nigris ; ventre luteo ; tegminibus coriaceis convexis, piceo-purpureis, costa albo-punctata, fascia media apiceque late albo-farinosis, hoc tuberculo nigro, appendicula terminali instructo; alis posticis convexis costa ad apicem profunde sinuata apice ipso falcato, tibiis auticis dilatatis, posticis 4 spinosis.

OBs.-Hoc insectum ad familiam Fulgoridarum revocandum, Eurybrachi proximum.

Ancyra pitchy black, the face, crown of the head and pronotum transversely streaked with grey, the metanotum blood-red with two black spots, the abdomen black with the tip densely powdered with white; body beneatlı and legs black, the belly luteous, the tegmina coriaceous, convex, purplish-pitehy, with the costa dotted with white ; a fascia across the middle and the apex broadly powdered with white, the latter with a black tubercle from whence springs an elongated sleuder appendage widest at the tip; hind wings convex, the costa at the apex deeply sinuated, the tip itself falcate, the anterior tibixe dilated, the posterior pair with 4 spines.

Length of the insect $\frac{1}{8}$ inch.

Expansion of the tegmina (exclusive of the terminal appendages) 1 inch.

Iuhabits Moulmein. In the British Museum.

The plant represented in the plate is the Amphicome arguta Royle, from the Himalayan Mountains. 



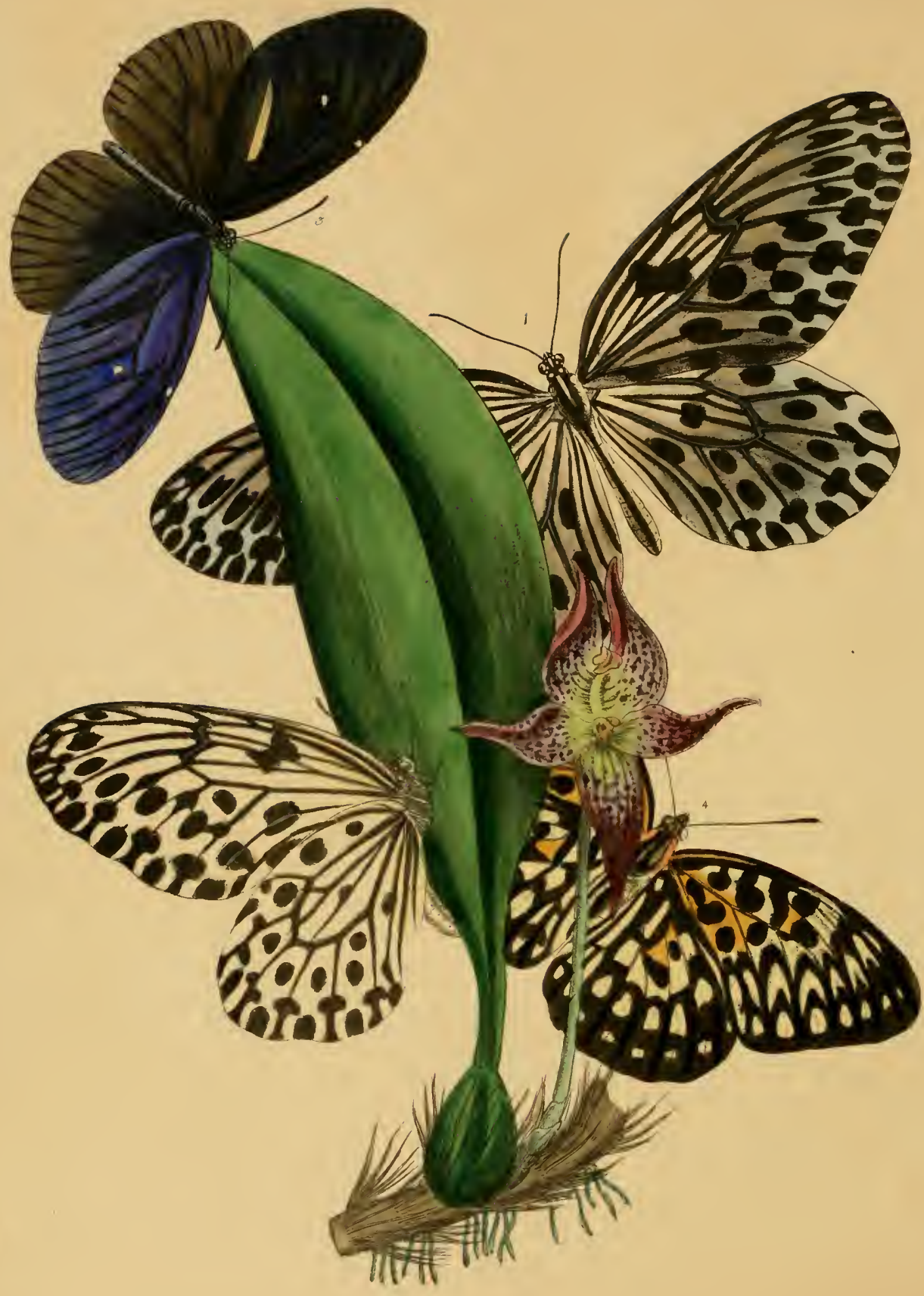


•

. 


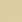




\section{PLATE XXXVII. \\ (ORDER-LEPIDOPTERA. \\ Section-Diurna.)}

FIGURE 1 .

IIESTIA HYPERMNESTRA. WESTw.

Ilestia alis subelongatis, fumosis (prosertim inter medium et apicem) nigro-maculatis et venosis ; costa nigrn macula parva subcostali anticarum cum macula arese discoidalis connexa ; scrieque macularum oblongarum pone medium cum margine apicali parallela, omnibus alis ad apicem maculis ovalibus inter venas, aliisque majorilus clavatis alternatis.

IIcstia, with the wings more elongate than in II. Idea (Agelia), and less so than in II. Lyncea ; pale blackishbrown, with spots and reins of black. The costa black, with a small subcostal spot connected with the patch of the discoidal cell of the fore wings; and with a row of oblong spots of black between the middle and apical margin, being parallel with the latter. Alt the wings with the apical margins marked with oval black spots betiveen the veins, alternating with larger clavate spots which rest upon the veins, inner false vein of the discoidal ccll of the hind wings, with a black spot on each side in the middle.

Expansiou of the fore wings $6 \frac{1}{\mathrm{i}}$ inches.

Inlabits Borneo. In the Collection of the British Museum.

Syx.-Idea fumana Boisduval MS. in Doubleday, Gen. of Diurnal Lep. ?

Obsenvation.-This species differs from Hestia Idea, Lenconoe, Aza, and D'Urvillii in the smoky appearance of the wings, from Lyncea in the less elongated wings, and the diffcrent position of the spots of the fore wings, and from Blanchardii in the variegated apical margin, and the form of the black spots.

\section{FIGURE 2.}

\section{HESTIA BELIA. Westw.}

Hestia alis ovatis, niveis, venis maculisque nigris, macula parva areæ discoidalis in aream subcostalem vix extensa, serieque macularum ovalium pone medium, cum margine apicale parallela, hoc in alis omnibus maculis oblongis inter venas aliisque clavatis alternatim notatis.

IIestia with the wings oval, snow-white, with the veins and spots black; the rather small spot of the discoidal cell scarcely extending into the subcostal area, and with a row of black oval spots beyond the middle of the wings, parallel with the apical margin, which is alternately marked with oblong-oval spots between the veins, and clavate ones placed on the veins; the inner false vein in the discoidal cell of the hind wings is marked in the middle of its outer edge with a black spot; the apical margin of the wings is rather irregular.

Expansion of the fore wings $5 \frac{1}{2}$ inches.

Inlabits Java. In the Collection of the British Museum.

Observations.-This species differs from H. Lyncea, Blanchardii, Hypermnestra, and Leuconoe, in the pure white ground-colour of its wings; from H. Idea in the oval, not longitudinal, markings beyoud the middle of the wings; from H. D'Urvillii in the smallness of the discoidal spots of the fore wings and the maculated hind wings; and from H. Aza in the difference of the marginal and submarginal markings.

Idea Gaura Horsf., and I. Daos Bdv., have been remored from the genus Hestia by Mr. E. Doubleday, on account of the structure of their antennæ and tarsi disagreeing with those of the species abore mentioned. 


\section{FIGURE 3.}

\section{EUPLEA DEIONE. WESTW.}

Euploea alis supra nigxis, anticis certo situ exruleo nitidissimis, versus medium punctis duobus albis strigaque fusco-sericanti ante marginem interuum ; posticis immaculatis; alis omnibus subtus fuscis punctis minutis albis versus basin, medium et apicem alarum.

Euploea with the wings above black, the fore ones in ccrtain positions splendidly glossed with blue, having two small white spots, one near the middle of the wings, and the other near the middle of the costa; a silky brown streak runs parallel to the inner margin near the first brancl of the median vein. The under wings are immaculate ; beneath all the wings are brown, rather paler beyond the middle; a few minute white spots are placed close to the base, several near the middle of each wing, (one being within the discoidal cell, and those of the fore wings being larger than those of the hind ones), and there is a row of minute submarginal white dots almost obliterated in the fore wings.

Expansion of the fore wings $4 \frac{1}{4}$ inches.

Inhalits Assam. Communicated by Major Jenkins.

\section{FIGURE 4.}

\section{ACONTIA DOUBLEDAII. WESTW.}

Acontia alis anticis basi luteis nigro maculatis et marginatis, apicibus late nigris maculis albis triphici serie ordinatis, I ma irregulari, 2nda e lunulis elongatis formata, 3tia maculari ; posticis basi nigro, albo et luteo variis ; apice late nigro, macularum albarum duplici serie ornato; 1 ma majorum ovalium, 2nda parvorum rotundatorum ; alis subtus similiter coloratis at paullo pallidioribus.

Acontia with the fore wings luteous at tle base, with spots and margins of black, the apical portion of the wings broadly black, with three rows of white markings, the first irregular, the second formed of elongated lumules, and the third formed of oval spots : the hind wings with the basal half varied with white, black, and luteous, the apical border broadly black, with a double row of white spots, the first larger and oval-shaped, the second smaller and rounded, the under side of the wings coloured and marked as above, but rather paler.

Expansion of the fore wings $4 \frac{1}{2}$ inches.

Inllabits Sylhet. Unique in the Collection of H. Doubleday, Esq., and communicated by E. Doubleday, Esq., in honour of whom it is named.

The plant represented in the plate is the Orchidaceous Bolbophyllum macranthum of Lindley, from Singapore. 



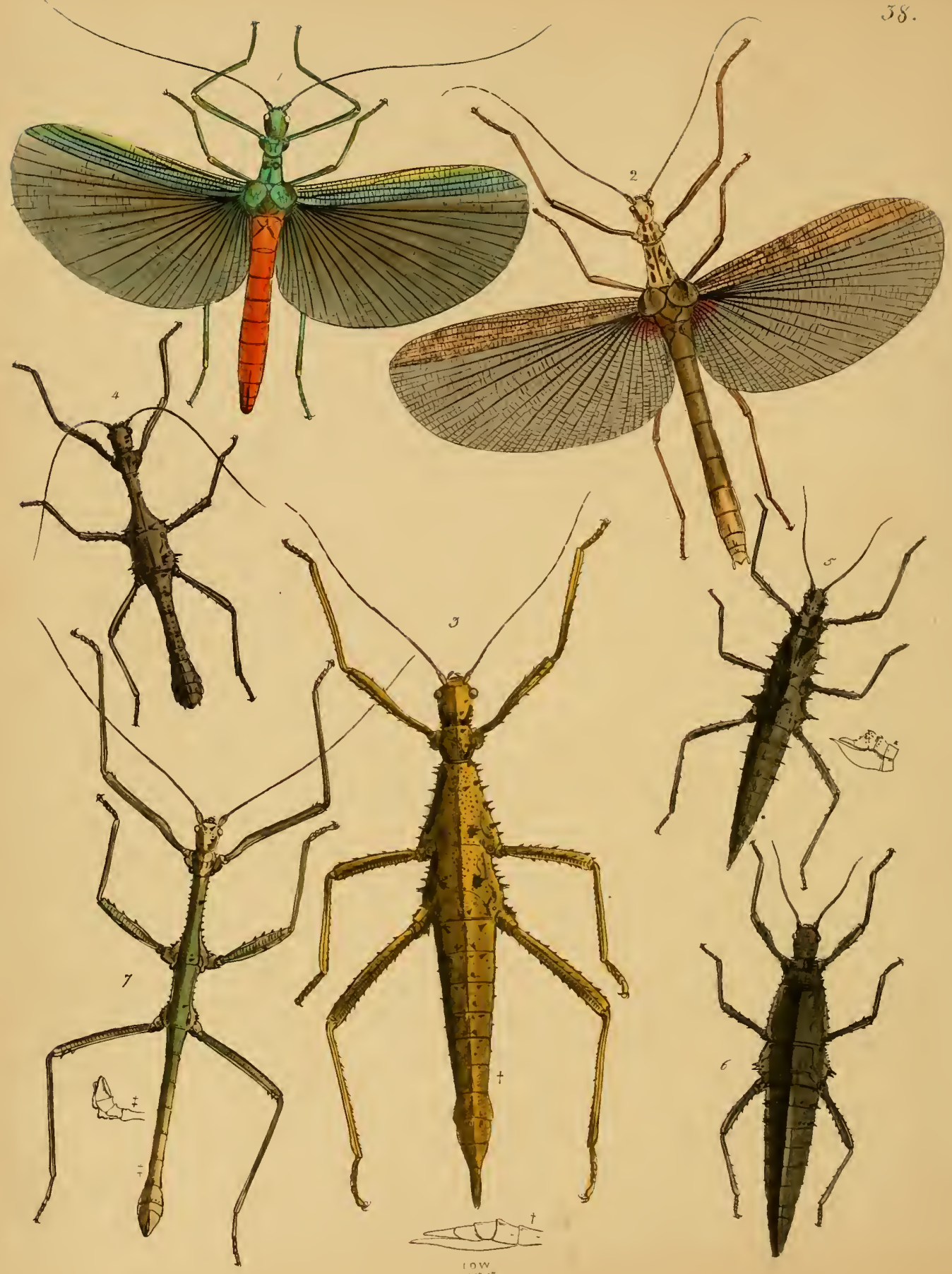






\title{
PLATE XXXVIII.
}

\author{
(ORDER-ORTHOPtera. Section-Ambrlatoma. Famliz-Phasmid. \\ FIGURE I.-PILASIIA (NECROSCIA) IIILARE. WESTW.
}

Plasma late virile, alis (nisi areà cestali viridi) fuscis, tegminibus externe flavo-marginatis; abdomine rufo, eapite inermi convexe, prothorace simplici, mesothorace (prothernee vix longiori) bitubereulato; lumeris tegminum in tubereulun elevatis; alis abdoninis longitudine: pedibus simplieibus parum elongatis, oviductu brevi simpliei.

Phasma of a fine grcen celour, with the wings (exeept the green cestal area) brown, the wing-eovers short and outwardly margined with yellow, the abdomen red; heal unarmed and convex, protherax simpie, mesotherax searcely longer than the protherax and furnished with two tubereles; the wing-eever's are elcvated near the shoulders into a raised conical protuberance; the wings nre as long as the abdemen; the legs simple, slender, and but little clongated, the ovipasitor short and simple (fenale).

Leng eerp $2 f$ ioches.

Inhabits Assam. Communicated by Lieut. Robiuson.

FIGLRE 2.-PHASMA (NECROSCIA) MACULICOLLIS. WESTW.

Phasma fuseum capite et thornce supra albidis hoe fusco maculato, alarum area cestali hutee brunneoque sulbvariegata ; parte postica fusea, basi extremo puniceo; eapite supra in tuberculum eonicum apice rotundato producto; anteunis albido aunulatis; mesothorace (prothorace duplo longieri) in medio bituberculate; tegminibus ad humeros angulato-elevatis; abdomine elongato cercis analilus divergentibus, eviductu brevi simplici ; pedibus simplicibus.

I'hasma brown, the head and thorax alove buff-roloured, the latter spotted with brown, the cestal area of the wings slightly variegated with elay-eoleured and richer brown; the posterier portion brown, with the extreme base pink; the hind part of the head is raised into a rouuded conical tuberele, the antenore are anuulnted with buff; the mesethorax is twice as long as the protherax, and furuished with two tulercles in the middle; the tegmina are elcrated into a conieal tuhercle near the shoulder's; the abdemen is elongated, with the extremity armed with two shert diverging appendages, the eviduct is short and simple, and the legs simple (fenale.) The male is very much smaller and more slender, the mesothorax without the two raised tulereles, and the abdemen terminated beneath by two incurved slender appendages.

Length of the malc $1 \frac{1}{2}$ inch, of the female nearly 3 inclies.

Inhabits Assam and Syllet. Communicated by Mrojor F. Jenkins.

\section{FIGURE 3.-PILASIA (ACANTHODERUS) BUFO. WIST:}

Phasma apterun fuscum, corpore in medio (prresertim metatherace) dilatato; granulato et spineso ; capite pestice spinis 4, prenoto sex, duobus intermediis majeribus, mesothorace lateribus spinose dorsoque spinis 2 ad marginem anticum, quatuor aliis ante medium, cum dualus majoribus elevatis versus marginem posticum; metathorace spinis duabus in medio alterisque 2 approximatis versus marginem posticum; abdeminis segmentis basalibus spinis duabus distantibus prope basin alterisque 2 appreximatis versus marginem posticum; segmentis posticis tubereulo elevato longitudinali ad marginem posticum, oviductu elongato contracte; pedibus spinosis.

Pbasma wingless, brown, with the body much dilated in the middle, especially across the metathorax, granulose and spined; the hind part of the head is armed with four spiues arranged in a square, the pronotum with six, the two intermediate ones being the largest; the mesothorax has the sides spined, and is armed with two spines close to the fore margin, four before the middle, and two larger and more elevated near the hind margin ; the metathorax has two large spines wide apart in the middle, and two close together near the hind margin; the basal segments of the abdomen are armed near the base with two spines wide ajart, and with two near together near the hind margin; the posterior segments are furnished with an elongated raised tuberele at the extremity; the evipositor is elongated and contracted behind, the legs are spined (female). The male is much smaller and narrower, but with the spines disposed as in the fenale.

Inhabits the Plilippine Islauds (Mr. Cuming). In Mus. Britann., Westw., \&c. Communieated by Captain Parry. FIGURE 4.-PHASḾL (ACANTHODERUS) MESOPLATUM. WESTw.

Phasma apterum fuscum granulosum et spinosum; mesotherace postice cum metathorace dilatato ; capite pestice spinis 8, lateralibus majoribus; prothorace spinis 2, mesothorace 8, 2 auticis, 2 ante medium, 4 posticis, quarcm 2 lateralibus; metathorace spinis 2 magnis pone medium hateribusque ante pedes posticos spinosis; segmentis basalibus abdominis 6-spinosis, spinis 2 anticis majoribus, segmentis posticis sensim dilatatis tubereulo longitudinali ad marginem posticum instructis; pedibus spinosis.

Phasma wingless, brewn granulose and spined ; the mosothorax behind, with the metatherax dilated and quadrate, the bead armed with 8 spines, of which the lateral ones are largest, the protherax armed with two spines, the 
mesothorax with 8,2 anterior, 2 xather before the middle, and 4 posterior, two of which are lateral ; metathorax with two large spines behind the middle, and the sides in front of the hind legs spined; the basal segments of the abdomen are 6-spined, the 2 anterior spines being the largest ; the hind segments are gradually dilated, and armed at the hind margin with a raised longitudinal tubercle; the legs are spined (male).

Length of the insect $2 \frac{1}{6}$ inches.

Inlrabits the Philippine Islands (Mr. Cuming). In the British Museum.

FIGURE 5.-PHASMA (PACHYMIORPHA) DRACONINUM. Westw.

Phasma apterum fuscum spinis magnis lateralibus horridum, corpore in medio parum dilatato ; capite supra postice spinis circiter 10 armato lateralibus majoribus; prothorace supra utrinque tubereulo plano elevato spinoso armato, mesothorace etiam supra versus marginem anticum utrinque tuberculo lato spinoso et dentato, postice convergenti armato, prope marginem posticum etian tuberculo minori e spinis duabus conjunctis armato; tuberculo simili in medio metathoracis; segmentis basalibns abdominis utrinque spina porrecta medioque uniea minori armatis: segmentis posticis sensim angustioribus, analibus tuberculatis; pedibus spinosis.

Phasma wingless, lrowu, and armed with large lateral spines; the middle of the body is slightly broadest, the head above is armed behind with about 10 spines, of which the lateral ones are the largest; the prothorax is armed on each side above with two broad flat elevated and spined tubercles; the mesothorax has also a pair of the same kind of tubercles near the frout margin, convcrging towards each other behind, and near the hind viargin is a smaller tubercle composed of two conjoined spines; a similar compound tubercle arms the middle of the metathorax; the basal segments of the abdomeu are armed with a strong porrected spine, and in the middle near the hind nuargin with a smaller one; the posterior segments are gradually narrowed (in the female) with the anal ones tubereulated, and the legs are spined (female). The male is much smaller, with the abdomen narrow, and of equal breadth throughont; the spines are arranged as in the female.

Length of the insect (male) $1 \frac{1}{2}$ inch, (female) $2 \frac{1}{4}$ inches.

Inhabits the Philippine Islands (Mr. Cuming). In Mlus. Britann., and Westwood. Communicated by Captain Parry.

FIGURE 6.-PHASHA (PACHYIORPIIA) DEPLANATUM. WESTw.

Phasma apterum planum, thorace e capite ad pedes posticos sensim dilatato; ferrugineo-fuscum opacum granulosum, eapite postice supra spinis 6 aliiş̧ue lateralibus parvis armatis, protlorace antice utrinque tuberculo plano spinoso armato; mesothorace antice area parum elevata utrinque angulata, lateribus postice couvergentibus instrueto, margiuibus granulosis spinisque dnabus supra pedes medios armato, metathorace etiam spinis 4 supra pedes posticos utrinque armato, hoe cun mesothorace ot abdomiue earina media longitudinali parum elevata instructo ; segmentis basalibus abdominis serie trausversa spinarum parvarum versus marginem posticum armatis ; pedibus brevibus spinosis.

Phasma wingless, flat above; the thorax from the head to the lind legs gradually dilated, rusty brown, opaque, and granulose, with the head armed behind on the upper side with six small spines and several other lateral ones; the prothorax has on each side in front a broad raised and spinose tubercle; the anterior part of the mesothorax is provided with a slightly raised space with the lateral margins convergent and the anterior angles acnte; the sides of the mesothorax are granulose, with two spines above the midule feet; the metathorax is also armed above the hind feet with 4 spines; the meso-, meta-thorux aud abdomen liave a slight raised longitndinal carina along the middle; the basal segments of the abdomen have a transverse series of small spines near the hind margin ; the legs are short and spined (female).

Length of the insect $2 \frac{1}{2}$ inches.

Inlabits the Philippine Islands (Mr. Cuming.) In the Collection of the British Museum.

\section{FIGURE 7.-PHASIA (LONCHODES) LUTEO-VIRIDE. WESTW.}

Phasma apterum, luteo-viride, glabrum, cylindricum, mesothoracis et metathoracis parte postica parum dilatata, capite spinis 8 in coronam cirenlarem dispositis; thorace et abdonine longitudine fere sequalibus, prothorace inermi, mesothoracis laterilıus spiuulosis, spinisque duabus in medio dorsi alterisque duabus approximatis ad marginem posticum; metathoracis lateribus spinulosis spinisque duabus pone medium disci armato; abdomine tenui, marginibus segmentorum param rugosis, apice clavato, fisso; pedibus intermediis brevioribus, femoribus dilatatis et spinulis nonnullis armatis ; femoribus anticis et posticis etiam intus ad apicem bispimulosis.

Phasma wingless, luteous-green, smooth, cylindrical, the hind parts of the meso-and metathorax dilated ; the bead armed with 8 spines arranged into a circular crown, the thorax and abdomen nearly equal in length, the prothorax unarmed, the mesothorax with the sides spinulose and with two spines in the middle of the back and two close together near the middle of the hind margin; the sides of the metathorax spinulose and armed with two spines beyond the middle of the back : the abdomen slender, with the margins of the segments subrugose, the extremity clavate and longitndinally eleft; the middle legs shorter than the rest, the thighs dilated and armed with a few short spines, the anterior and posterior thighs also armed within at the tips with two short spines (male).

Length of the insect 3 inches.

Inhabits Assam. Communicated by Lieutenant Robinson. 


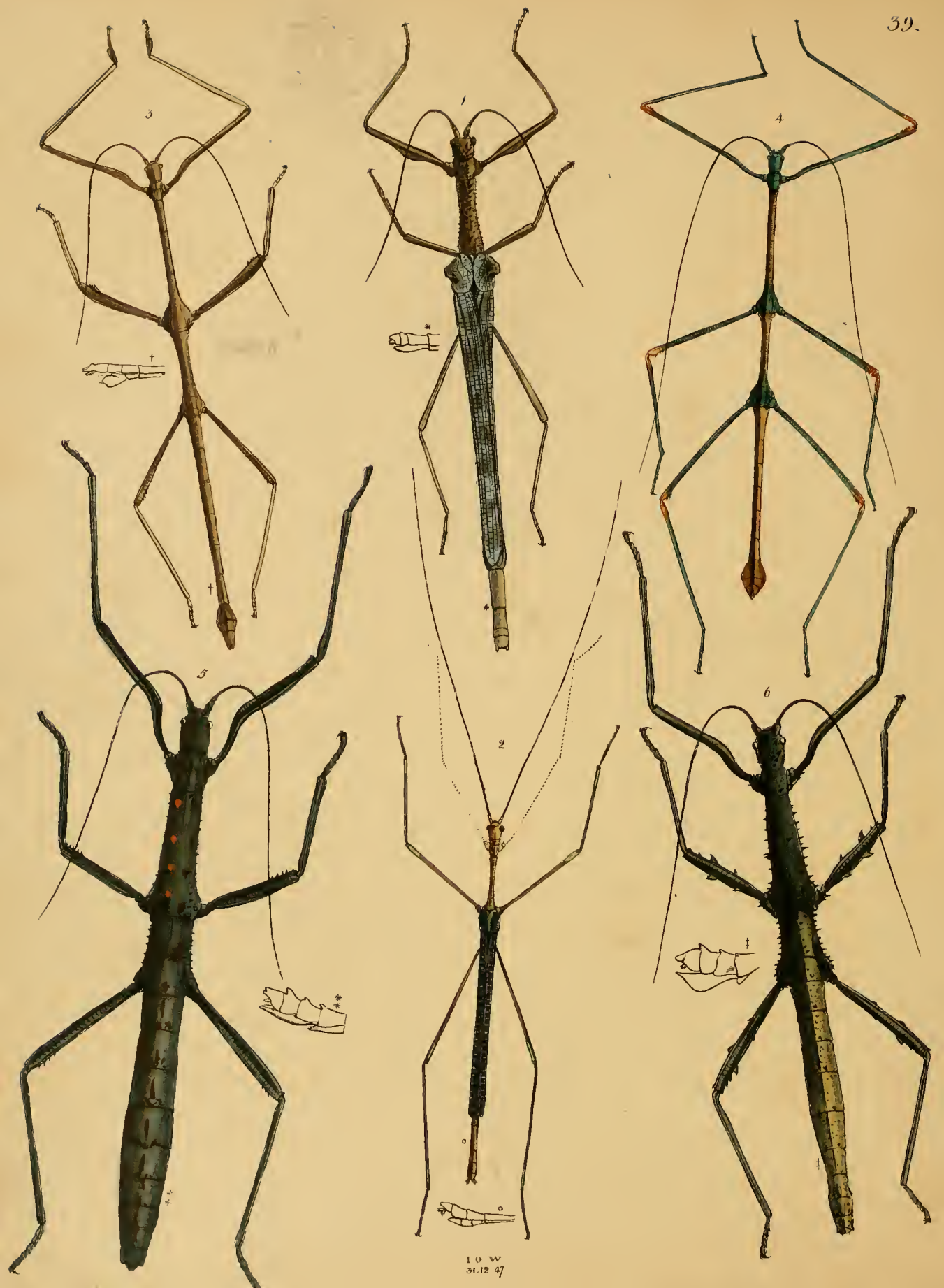



$-$ 


\title{
PLATE XXXIX.
}

\author{
(ORDER-ORtiloptera. Section-Ambelatoria. Family-Phasmidx.)
}

\author{
FIGURE 1.
}

\section{PIIASMA (NECROSCIA ?) CURTIPES. WESTw.}

Phasma clongatun cylindricum, albido-fusenm, eapite postice spinis numcrosis armato, prothorace spinulis 8 per paria dispositis, mesothoraco (prothorace plus quam triplo longiori) valde spinoso, spinis anticis majoribus; tegminibus griseis medio in tnberenlo nugno conico elevatis; alis abdomine brevioribus pallide fuscis, area costali griseo fusco-que varia, abdonine valde elongato, inermi, segmento 5 to ad apicem supra elevato, oviductu brevi simplici ; pedibns, presertim intermediis, brevibus, simplieibus, femoribus anticis parum dilatatis, articulo primo tarsorum anticorum valde clongato.

Phasma elongated, eylindric, buff-brown coloured, the bind part of the head armed with numerous spines; the prothorax armed with 8 small spines armanged in pairs; the mesothorax elongated (moro than thrice tho length of the prothorax), very spinose above, the anterior spines being the largest ; the tegmina grey, cach having the niddle, near the shoulders, elevated into a large raised conical tubercle; wings shorter than the aldomen, pale brown, the costal area varied with grey and brown; abdomen very much elongated, unarmed, the 5th segment with a raised tubercle at its extremity above ; the ovidnet short and simple ; legs, especially the middle ones, short and simple, the anterior thighs rather dilated; the first joint of the anterior tarsi mnch clongated (female).

Length of the insect 4 inches. Allied to Ph. Auritum Fabr.

Inhabits Prince of Wales's Island (Dr. Cantor). In the Collection of the Rev. F. W. IIope.

\section{FIGURE 2.}

\section{PHASMA (NECROSCIA) FILUM. WESTW.}

Phasma filiforme antennis pedibusque longis gracillimis, viridi-fuscum; capite luteo, inermi ; antennis fuscis, albido 5-annulatis ; prothornce luteo, fuseo vario ; mesothorace gracillimo, subscabro ; tegminibus brevilsus, nigris, margine interno viridi, versus humeros parum angulato-elevatis; alis abdomine brevioribus, fuscis, area costali nigrieanti venis transversis pallide viridibus ; abdomine cylindrico apice appendieulis duobus divergentibus instructo ; pedibus inermibus, femoribus tibiisque ad apicem pallide viridi late-annulatis, articulo primo tarsorum clongato.

Phasma filiform, with the antenna and legs long and very slender, green-brown; the head luteous and unarmed; antenna brown with 5 pale buff rings; prothorax luteous, varied with brown; mesotborax very narrow, rather rongh; tegmina short, black, with the inner margin green, slightly augularly elevated near the shonlders; wings shorter than the abdomen, brown, the costal area blackish with the veins transversely streaked with pale green; abdomen cylindrical the tip furnished with two diverging appendages; legs unarmed, the femora and tibise broadly amulated with pale green near the tips, the first joint of the tarsi elongated (male-fore legs wanting).

Length of the insect $2 \frac{3}{4}$ inches.

Inlabits Prince of Wales's Island (Dr. Cantor). In the Collection of the Rev. F. W. Hope.

FIGURE 3.

\section{PHASMA (LONCHODES) UNIFORME. WEST.}

Phasma elongatum, apterum, cylindricım, inter pedes intermedios paullo dilatatum, fuscum opacum, inerme ; thorace et abdomine longitudine fere æqualibns (mesothorace quartam partem longitndinis corporis excedente) ; pedibus anticis elongatis, gracilibus, articulo primo tarsorum elevato; pedibus intermediis breviorilus crassioribus (præsertim femoribus), his ante apicem intus spinulosis ; pedibns posticis subelongatis, gracilibns, tarsorum articulo Imo parum elongato, abdominis apice dilatato fisso.

Phasma elongated, wingless, cylindrical, the body suddenly dilated between the middle feet, opaque brown, nnarmed ; the thorax and abdomen nearly equal in length, the mesothorax being more than one-fourth of the length of the entire body; fore legs elongated, slender, the basal joint of the tarsi dilated above ; middle fcet short and thickened, especially the thighs, which are armed neax the tip within with several small spines; hind legs rather elongated, slender, the first joint of the tarsi slightly elongated, apex of the abdomen dilated and cleft (male).

Length of the insect $3 \frac{3}{4}$ inches.

Inhabits Prince of Wales's Island (Dr. Cantor). In the Collection of the Rev. F. W. Hope. 
FIGURE 4.

\section{PHASMA (BACTERIA) GENICULOSUM. Westw.}

Phasma elongatum, apterun, cylindricum, inerme, obscure fuscum ; apicibus meso- et metathoracis subito æequaliter dilatatis viridibus; capite et prothorace inermibus, viridibus, thorace abdomine toto parum longiori, abdominis apice dilatato fisso; pedibus elongatis, viridibus, onnibus femorum apicibus læte rufis et intus spinulis nonnullis minutis armatis; pedibus intermediis reliquis parum brevioribus sed vix crassioribus, tarsorum articulo basali elongato.

Pliasma elongated, cylindric, wingless, obscure brown, unarmed; the extrenity of the meso-and metathorax suddeuly and equally dilated and green; the bead and prothorax simple, green, the thorax rather longer than the entire abdomen, the extrenity of which is dilated and cleft; legs long, slender, and green, the tips of all the femora with a broad ring of red and internally armed with several minute spines; middle legs rather shorter but scarcely thicker than the rest, tarsi simple, with the basal joint elongated.

Length of the insect $3 \frac{1}{3}$ inches. (Louchodes geniculatus Gray, Syn. Phasm. p. 19 ?)

Inlabits Prince of Wales's Island (Dr. Cantor). In the Collection of the Rev. F, W. Hope.

\section{FIGURE 5 .}

PHASMA (ACANTHODERUS) DESPECTUM. WESTW.

Phasma apterum, subcylindricum, latitudine fere æquale, fusco-nigricans opacum, subscabrum ; capite postice quadrato, serieque postica tubereulorum parvorum instrueto; thorace fere abdominis longitudine ; pronoto spinulis minutis armato; mesothorace lateribus spinulosis, dorso 12 spinoso, spinis 2 anticis majoribus et approximatis, 2, 2, 2 distantibus, et 4 posticis approximatis, ultimis 2 compositis ; metathorace oblongo lateribus spinulosis, dorso in medio spinis duabus squamisque duabus liberis tegminiformibus; segmentis abdominalibus tuberculo elevato in medio marginis postici, in segmentis basalibus fere obliterato, segmento ultimo trilobo, oviduetu subtus in medio carinato pedibus mediocribus, intermediis parum brevioribus ; femoribus ad apicem intus spinulosis ; tarsis articulo basali abbreviato, præsertim in pedibus 4 postieis.

Phasma wingless, somewhat eylindrical, of nearly equal width throughout, blackish-brown, opake, rather rough ; the head square behind, and with a series of small tubercles along tbe posterior margin; thorax nearly equal in length to the abdomen; pronotum armed with several small spines; mesothorax with the sides spimulose, the back with 12 spines, two larger close together in front, then 2, 2, 2, wide apart, and 4 lind ones elose together, the two hindermost ones being formed of several spines conjoincd together; metathorax oblong with the sides spinulose, the middle of the back with two small spines and with two small free seales bike tegmina; each of the segments of the abdomen furnished with an elevated tubercle in the middle of the hiud margin, being almost obsolete in the anterior segments, the terminal segment trilobed, the oviduct beneath channelled along the centre; legs of moderate length, the middle pair being rather the slortest; thighs armed with several minute spines near the tip within ; tarsi with the basal joint short, especially in the fom hind legs (female).

Leugth of the insect $4 \frac{1}{4}$ inelies.

Iuliabits Sylhet. In Mus. Westwood.

\section{FIGURE 6.}

PHASMA (ACANTHODERUS) LACERTINUM. WESTW.

Plasma apterum, subcylindricum fuscum, opacum rugosum et spinosum, eorpore in medio parum latiori ; eapite ovali, vertice spinuloso spinis 3 majoribus in ovalem dispositis; prothorace spinulis duabus versus margimem posticum ; mesotboracis, lateribus et disco irregulariter spinosis, spinis duabus approximatis versus marginen posticum ; metathorace spinulis lateralibus duabusque mediis ; abdomine seabro, singulo segmento tuberculis duobus majoribus versus marginem posticum, segmento 6 to contracto, oviductu subtus dilatato et carinato ; pedibus anticis elongatis, inermibus, intermedüs brevioribus, femoribus erassioribus spinis dilatatis; femoribus posticis spinis minoribus armatis, tarsorum intermediorum articulo basali brevi, in posticis pedibus magis elongato.

Phasma wiugless, subcylindrieal, browu opaque, rugose and spinose, the body rather widest across the middle ; head oval, the erown armed with small spines and with 8 larger ones, arranged in an oval; prothorax with two small spines near the hind nargin ; mesotlorax with the sides and back irregularly spined, and with two spines close together near the bind margin; metathorax with sides spined, and with two small spines in the middle; abdomen rough, each segment with two larger tubereles near the hind margin, the 6 th segment narrowed, the oviduct dilated beueath and keeled; fore legs elongated and simple, middle legs shorter, with the femora thicker and armed with dilated spines; hind thighs with smaller spines, the middle tarsi with the basal joint short, the lind ones with it longer (female).

Length of the insect $3 \frac{5}{6}$ inches.

Inlabits Assam. Communicated by Major Jenkins. 


\section{PLATE XL. \\ (ORDER-LEPIDOPTERA. \\ Section-Diursa. \\ Family-Papilionid.e.)}

FIGURE 1.

PAPllio MiNerets. (Grar Zool. Misc., p. 32, and Lep. Neral, t. I.)

Papilio alis antieis onnino et basi alarum posticarum obseure fuseis, illis nigro striatis his poue medium nigris eaudatis, et valde sinuatis, macula magna alba discoidali (venis tribus divisa) lunulis 4 (externa precedenti minori), maeulaque rotundata eaudali alteraque subanali rufis; eapite et eollare rufe-variegntis. $\delta$ \&.

Papilio, with the fore wings entirely, and the hind wings at the base, dull brown; the former longitudinally striped with black between the veins, the latter black beyond the middle, tailed and deeply sinuated, with a large white diseoidal spot (extending to the anal margin and divided by three veins), and with 4 lunules (the outer ene being smaller than the preceding), a round spot near the extremity of the tail, and another smaller spet in the angle below the anal angle, all red, irrorated with brown seales. The head, neck, and abdomen beneath varied with red. (Male and female).

Expansion of the fore wings, 5 inches.

Inhabits Nepaul. In the Collection of the British Museum and Mr. MacLeay.

Syn. Papilio Latreillii. Donov. Nat. Repos. v. 4, pl. 140 (pessima.)

Observations. - I think it not improbable that it will ultimately be found that this supposed species is only a local variety of the following :-

FIGURES 2, 3, 4, and 5 .

Papilio Plilloxenus. (Grat Zool. Misc., p. 32, and Lep. Nepal, t. 2.)

Papilio alis anticis maris nigris, fomine fuseis nigro lengitudinaliter striatis, postieis elongatis caudatis, valde sinuatis, maeula magna oblonga alba versus angulum externum, puneto vel mneula minori utrinque interdum adjecta, lunulis tribus rufis vel albo-rufis maculaque rufa ad apieem caudse strigaque in pagina infera, ex angulo anali rufis.

Papilie, with the fore wings of the male black, the female brown with blaek longitudinal streaks hetween the veins, the hind wings more or less elongated, tailed, and deoply sinuated, with a large white spot near the outer angle, oceasionally with a smaller spot on either side of it, and with three red, or red and white limules, a red spot at the extremity of the tail, and with a variable streak of red extending inwardly from the anal angle on the under side of lind nings.

Expansion of the fore wings, $4 \frac{2}{4}$ to $5 \frac{3}{4}$ inehes.

Inhahits Assam, Sylhet, Nepaul, \&e.

OBSERVATIONS. - I hafe considered the different insects represented in figures 2, 3, 4, and 5, in the accompanying plate as local rarieties of one species (to which probably P. Mincreus will subsequently have to be added).

Figure 4 will be seen in its general form to agree with $P$. Minereus, as well as in possessing a white tripartite spot near the anal angle of the hind wings on the upper side. This variety is in the fine collection of Captain Boys. The markings on the upper side of the hind wings exhibit very little red; they are more brilliant on the uuder side in which the spots at the anal angle are 
larger, and as the large oblong pateh near the outer margin is accompanied on its inside by a small spot, there is a continnous series of spots of irregular size from the anal angle to the outer angle. Captain Boys possesses a male insect, which is doubtless the malc of that here figured, whieh wants the white spot near the anal angle on the upper side, and the spot at the extremity of the tail is nearly obliterated on this side.

Figure 5 represents a very large female from Assam, communicated by Major Jenkins, distinguished hy the very great breadth of the tails of the hind wings, and by the spots (except the large one near the outer angle of the hind wings) being on the upper surface scarcely varied with red. Most of the specimens which I have seen from Sylhet and Assam agree in this latter respect, whereas,

Figure 2, which is drawn from the type specimen of P. Philoxenus, has the tail but moderately broad, and the spots on the upper side of the hind wings are (except the large outer one) strongly marked with red. This is a native of Nepaul.

Figure 3 represents another insect from Sylhet, which Mr. E. Doubleday (Zool. Misc., p. 74) described under the name of $\mathrm{P}$. Polyeuctes, but which he now cousiders as a variety only of P. Philoxenus. The posterior wings are very much elongated, and on the upper side the large white spot of the hind wings is not accompanied by the two small spots visible on either side of it on the under surface, nor is the red mark at the anal angle visible. Mr. Doubleday having represented the upper side of this supposed species, in his work on the butterflies now in course of publication, the under side is here given, copied from a figure communicated by Mr. Doubleday.

On attentively looking at all these insects, and allowing for the variations which occur in different specimens, especially when captured in different localities, it will be admitted that they all possess but one type in the markings, the spots oceurring in all the same relative positions, and varying only in the greater or less extent, or even the oceasional absence of some of them.

The plant represented in the Plate is the newly-imported Chirita sinensis. 

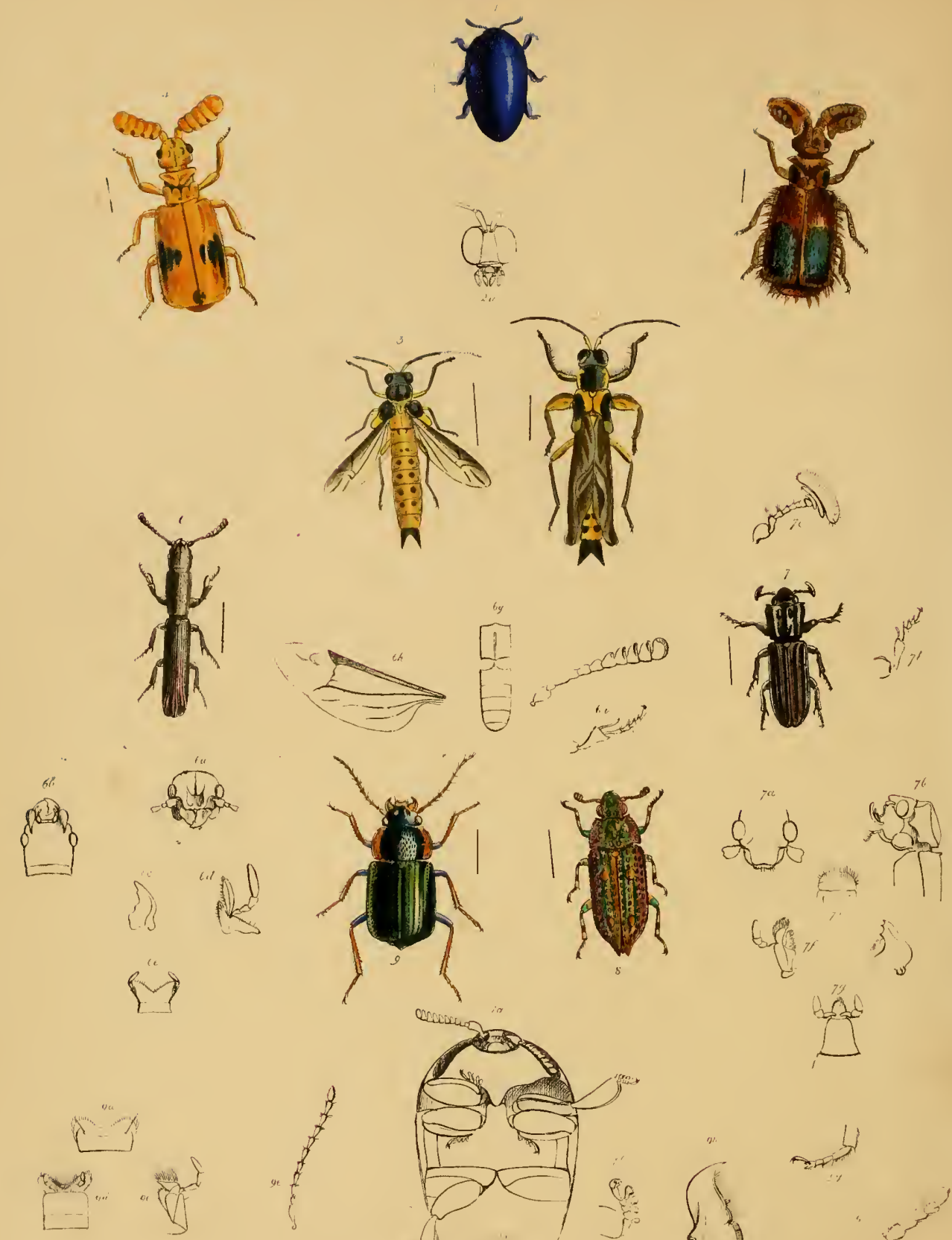




\section{(ORDEI-COLEOPTERA.)}

I HAVE represented in the present Plate a scries of bectles which, although not remarkable for their size, especially merit the attention of the Entomologist for the singularity of many of their charneters, and the interest belonging to them from their position in the families of Colcopterons insects.

\section{VIGURE 1.-GALBELLA VIULACEA. Westw.}

Cusa. Ges. Genus norum Galbe et Pterotarso in funilia Enenemidarum affinc. Corpus breve, ovale. Antenne serrate, in cavitatihus marginalibus prosterni reeepte. l'rostemum postice productum mesosterni apice dilatato receptum ; pedes lati contractiles, tarsis 4-laminiferis.

fiseric Cunasctir. A new genus uearest allied to Galba and Pterotarsus in the family Euenemidre. Body short, oval ; antenne serrated; reecived when at rest in longitudinal envities at the sides of the prostcrum. Prosternum produced behind and received in the dilated aplex of the mesosternum. Legs brond, contractile; tarsi with 1 lamellie.

C1.ı. Sp,-Galbella violaceo-cavulea nitida, prothorace sub lente eireulariter minute punctato; elytris minute punctatis, punetis in lincas uumerosas irregulares dispositis.

Galbella violet-blne, glossy, the prothorax under a lens covered with minnte eircular punetures; elytra also very finely punctured; the punctures forming many irzegular rows.

Length of the body, 21 lines. Iuhabits the East Indics. In the Colfection of A. Melly, Esq.

Figure $1 a$, represents the under side of the insect highly magnified; $1 b$, one of the tarsi.

FIGURE 2.-ICHTIYIRUS LATERALIS. WEST.

Cuar. Gex,-Genus norun, Telephoro et Malthino in familia Telephoridarum aftine. Corpus elongatum depressum; oculi magui, antenne filiformes ; mandibulac graciles, acutre, intus 2-dentat:e; pajpi omnes articulo ultimo sceuriformi; clytra abbreviata, apiee angustato; alse feve longituline abdominis ; abdoucu articulo magno corneo, profuncle fisso, in utrorpe sexu terminatum, pedes clongati; tarsi articulo 4to dilatato; podes intermedii in marc difformes, femoribus dilatatis, curvatis, tibiisque brevibus irregularibus.

Gexmic Cuaracter.-A ncw Genus allied to Telephorus and Malthinus in the funily Telephoridx. Body elongate; depressed; cycs large, antenna filiform; maudibles slender, acute at the tips, intervally 2 -dentate; all the palpi with the last joint long and seeuriforn ; elytra very short, the tips narrowed and rounded ; wings nearly as long as the abdomen; abdomen terminated in both sexes by a large lorny cleft joint; legs long; tarsi with the 4 th joint dilated ; middle legs in the male deformed, the thighs swollen and eurved, and the tibire short and irregular.

Ichthyurus capite nigro, facic subtns, et articulis basalibus anteunarum flavis, palpis nigris, prothorace nigro, latcribus latè et margine tenni postico flavis ; scntcllo flavo ; elytris nigris humeris anguste, suturaque late flavis, apicibus fuseis ; abdomine segmentis basalibus nigris flavo marginatis, apicalibus flavis, basi nigris; segmento ultimo nigro ; alis fuscis ; pedibus fuscis, basi flavis ; tibiis anticis maris curratis setosis ; femoribus intermediis dilatatis intus subserratis, tibïs ante apiccm intus tuberenlo armatis, pedilus fominre simplicibns.

Ichthyurus with the bead black, the lower part of the face aut basal joints of the antenna yellow, palpi black, prothorax black, the sides broader, and the hind margin narrowly margined with yellow; scutellum yellow; elytra with the shoulders narrowly and"the suture broadly yellow, the tips brown; wings brown; abdomen with the basal segments black, edged with yellow, the apienl ones yellow, black at the base; terminal joint black; legs brown, yellow at the base, anterior tibie of the male cnrved and setose; intermediate femora dilated, subserrated benenth; tibire with a tuberele near the apex on the inside, legs of female simple.

Length of the insect, 4 lines. Inhabits the Island of Java. In Mus. Westwood.

ObSERTATION.-Both sexes of this very iuteresting species have been kindly communicated to me with other raluable insects by MI. Westermann of Copenhagen.

Figure $2 a$, represents the head seen in front.

FIGURE 3.-ICHTHYURUS COSTALIS. WESTw.

Ichthyurus capite nigro, facie flava, antennis nigris basi flavis; prothorace nigro opaco, margine postico aureo, carina media postiea polita; elytris nigris apice flavis; meso- et metatlıorace flavis, abdomine flavo segmentis intermediis nigro-bimaculatis, segmento ultimo nigro; alis costa pallide fusca ; metasterno nigro, pedibus fuscis, femoribus flavis. +

lchthyurus with the head black, opaque; the face betwcen the base of the antenna and mouth yellow ; antenna black, with the first and second joints yellow ; protliorax black, opaque, very elosely and densely punctured under a lens with a raised polished longitudinal carina beyond the middle, and a row of punetures within the front margin, 
the hind margin sinuated near the posterior angles and golden yellow; mesothorax jellow, elytra black, yellow at the tips, metathorax yellow, abdomen yellow with two black spots on each of the intermediate segments, the terminal segment black and finely punctured and pubeseent; wings with the costal portion pale brown, metasternum black, legs brown, femora yellow. (Female.)

Length of the insect, 5 lines. Inhabits the East Indies. (Moulmein). In the Cabinet of the British Museum.*

FigURE 4,-MERISMODERUS BENSONI. Westw. (Trans. Ext. Soc. 5, p. 23.)

Merismoderus luteo-fulvus, opacus, capite punctulato supra impressionibus duabus rotundatis inter oculos alteraque versus medium marginis antici; prothorace bipartito, parte antica angulis anticis productis subacutis, parte postica quasi 4-lobata ; elytris coriaceis, singulo versus medium plaga magna nigra irregulariter triangulari ad suturam haud extensa, disco nitidissimo, maculaque parva communi nigra ad apicem suturse, lateribus setulosis.

Merismoderus fulvous-clay coloured, opaque; the head with small punctures and with two round impressions between the eyes and another shallower near the middle of the fore margin ; prothorax bipartite, the anterior angles of the fore part prominent and rather acute, the hind part somewliat 4-lobed; clytra leathery, each having near the middle a large black irregularly triangular patel not extending to the suture, its disk being very glossy ; and with a small black patch at the extremity of the suture, the sides setose.

Length of the insect, 3 lines. Inlabits the East Indies near Cawnpore and Saharumpore. Found in a black ant's nest. Communicated by W. H. Benson, Esq.

FIGURE 5.-PAUSSUS JERDANI, Hope MS. (Whatw, in Trans. Ent. Soc. 5, p. 26.)

Paussus prothorace quasi bipartito; antennarum clava postice valde excavata, capitis vertice excavationibus duabus ovalibus, tuberculo elevato in singula excavatione; rufescens obscurus, undique setulis minimis luteis obtectus ; elytrisque setis longis numerosis rufescentibus marginatis, his etiam plaga maxima postica nigra notatis.

Paussus with the prothorax appearing bipartite, and the clava of the antennæ posteriorly deeply excavated; the crown of the head with two oval excavations, each containing an elevated tubercle : entirely dusky red, obscure, and clothed with very minute luteous scales, each elytron having a rery large black spot on the posterior part, and the sides and extremity margined with long reddish bristles.

Length of the insect, 3 lines. Inhabits the East Indies. In the Collection of the Rev. F. W. Hope.

Observations. - Now that it has been satisfactorily ascertained by various competent observers that the species of Panssidre frequent the nests of different species of ants (not white ants), it is to be hoped that our Indian and Australian collectors will add considerably both to our knowledge of new species, and to our cabinets, by the capture of specimens of some of those already described. Fifty-two species of this family are figured in my Arcana Entomologica, and ten others subsequently discovered, are noticed in the Fifth Volume of the Transactions and Proceedings of the Entomological

* The following are the characters of two other species of this curious new genus :-

ICHTHYuRUs Basalis. Westw.-Capite nigro, facie flava, antennis nigris articulo hasali flavo; prothorace flavo, maculis duabus ovahibus nigris in medio conjunctis, polito, serie punctorum prope marginem anticum et posticum; elytris nigris humeris externe Havescentibus ; alis fuscis, tertia parte basali pallida, pedibus nigris.

Ichthyurus with the head black, the face yellow ; antennse black with the basal joint yellow ; prothorax yellow with two black oval spots on the disc united together in the middle, polished, and with a row of punctures near the fore and hind margin ; elytra black, the shoulders outwardly yellowisl, wings brown, one-third part at the base being pale, legs black-abdomen mutilated.

About the size of $\mathrm{I}$. Costalis.

Inhabits the East Indies. (Moulmein.) In the Collection of the British Museum.

Iснтнyurus nisconnalis. Testw.-Capite nigro; facie subtus et basi antennarum flavis ; palpis nigris, prothorace nitido piceo margine postico pallidiori, elytris flavis basi cum scutello pallidioribus disco piceo, abdomine flavo ad basin piceo-vario, segmento apicali nigro, ahis fuscis; pedibus anticis maris simplicibus flavis, femoribus in medio tarsisque fuscis, femoribus intermediis valde inflatis, flaris, in medio macula magna ovali nigra, subtus excavatis basique spinis duabus oblique truncatis armatis, tibiis trevissimis, curvatis, crassis ; pedibus posticis fuscis basi femorum flavescentibus.

Ichithyurus with the liead black, the under part of the face and base of the antenna yellow ; palpi black ; prothorax glossy, pitchy, the hind margin paler ; elytra yellow, the base and scutellum paler, the dise pitchy; abdomen yellow, varied with pitchy at the base, the terminal segment black; wings brown, fore legs of the male simple, yellow, the middle of the femora and the tarsi brown; intermediate femora of the male very much inflated, yellow, with a large oval black spot on the outside, beneath excavated asd the base armed with two spines obliquely truncate at their tips; tibire very short, curved and incrassated; hind legs brown, with the base of the thighs yellowish.

Length of the insect, 4 lines. Inhabits Sierra Leone. (D. Strachan.)

I am indebted to the Rev. F. W. Hope for my specimen of this remarkable insect. 
Society, and of these sixty-two species (a great portion of which are Indian) many are kuown only by solitary incliriduals, whereas the ciremistanees stated by Mr. Beuson in lis Notes on the Capture of Paussi at the Cape of Good Hope (Trans. Ent. Soc. vol. 5, p. 30), sufficiently show that if the natural habitats of these insects were examined, a rich harvest would be the reward of the Entomologist's cxertions; the more especially as the recent researehes of continental Entomologists hare shown that very many curious species belonging to other families also take up their abode in ants' nests.

\section{FIGURE 6.-PRIONOPIIORA CYLINDRICA. WEST.}

Cun G. Gex.-Genus novum Passandre et Calodromo (ante, pl, 15, fig. 4, 5, nuaximo affine ; corpus cylindricum, angustum ; enput antice canaliculatum, antenna longitudine protloracis, articulis 6 apicalibns sensim latioribus interne sernatis, mandibuixe intus obtuse dentate; genre sulstus dilatatre, os latcraliter claulentes; maxillæ lollo elongato simplici, lobo interno producto setoso; nentum transversum, labinm majus, angulis anticis rotundatis, in neclio profundo enarginato, palpi simpliecs. Elytra ad apicem longitudinaliter impressa et carinata, pedes breves, calcaria præsertim pedunı nnticorun, elongata ; tarsi distinete 5-articulati, simplices.

Generic Citaracter. - A uew genus, nearly allied to I'assandra and Calodromus (ante, pl. 15, fig. 4, 5) ; body eylindric, narrow; head clannelled in front; antenne as long as the prothorax, with the six terminal joints gradually broader and internally scrrated; mandibles inwardly obtusely dentate, eliecks dilated beneath, sluutting in the sides of the mouth; maxilla with an clongated sinple terminal lobe, and the inner lobe produced and sctose; mentum transwerse, labium larger, with the fore angles rounded and the middle deeply emarginated, palpi simple. Elytra at the tips longitudinally channclled and keeled, legs short; spurs, especially of the fore legs, long ; tarsi distinctly 5-jointed, simple.

Prionophora nigra nitida, apicibus elytrorum castanco-uigris ; eapite et prothorace punctatis, punctis elongatis; elytris striato-punctatis, apice impressis, sutura carinisque trilus elevatis; prosterno utrinque sub-excavato pro receptione pedun anticorum; metastcrus canali abbreviato impresso.

Prionophora black, shining, with the tips of the elytra chesnut-black; the head and prothorax punctured, the punctures small, but elongated ; elytza striatc-punctate ; the extrenity of each impressed, the suture, margin and two earinse in the middle elevnted and glossy ; prosternum impressed on each side for the reception of the fore legs; metastornum with an abbreviated cluannel in the middle.

Length of the insect, 4 lines. Inhabits ludia. In the Collections of the British Mluscum and the Linnean Society.

Figure $6 a$, represents the head, seen in front; $6 b$, the head, scen beneath ; $6 c$, the mandible; $6 d$, the maxillie; $6 e$, the mentum, \&c. ; $6 f$, the antenux ; $6 g$, the under side of the metathorax and abdomen ; $6 h$, the wing; $6 i$, the fore tibia and tarsus.

\section{FIGURE $7 . \rightarrow$ PETALOPHORA COSTATA. WESTW.}

Cu.ır. Gr..-Genus novum inter Coleoptera Xylophaga anomalum, Ceryloni et Bitomæ forsitan affine ; corpus subcylindricum, subelongatum; eaput parvum triangulare; labrum semi-circulare; mandibulæe subtriangulares sub apicem dentibus 2 minutis armatæ, medio marginis interni membranaceo ; maxille lobis duobus latis membraceis eibatis; mentum quadrangulare antice parum angustum; labium parvum apice rotundato; palpi omnes simplices, apice acuminati ; antenne breres 11 -articulatæ, articulis 3 ultimis clavam magnam e laminis complanatis setosis, ultima naxima, formatis; prothorax rugosus antice declivis; elytra costata ; pedes breves, femoribus latis; calcaria elongata, tarsi distincte 4 -articulati simplices.

Generic Character. $-A$ new and anomalous genus among the Xylophagous Colcoptera, apparently allied to Cerylon and Bitoma; body subcylindric and suluelongated; head small and triangular; labrum scmicireular, mandibles not porrected, subtriangular, armed with two small teeth below the tip, the middle of the inner margin being membranaceous ; maxillx witl two broad membranaceous eiliated lobes; mentum quadrangular, somewhat narrowed in front; labium small, rounded at the tip; all the palpi simple, with the tips somewhat acuminate; antenna short, 11-jointed, the three last joints forming a large laminated setose club, the first joint being very small, and the last joint very large and curved; prothorax rugose, the anterior margin deflexed ; ely tra costated ; legs short, femora broad, spurs elongated (especially in the fore legs); tarsi distinctly 4-jointed, simple ; pulvilli wanting.

Petalophora nigra, piceo parum tincta, pedibos piceo-nigris; eapite punctatissimo ; pronoto inæquali punetato, margine antico deflexo; utrinque eanali impresso cum lateribus parallelo; clytris irregulariter punctatis, singulo costis tribus longitudinalibus nitidis instructo.

Petalophora black, slightly tinged with 'pitchy, with the legs pitchy black; head very closely punctured; pronotum uneven, punctured with the fore margin deflexed, and furnisbed on each side witb a longitudinal impressed channel, parallel with the lateral margin; elytra irregularly punctured, each with three longitudinal raised shining ridges.

Length of the insect, 4 lines. Inhabits the Island of Java. In the Collection of A. Melly, Esq. 
Figure $7 a$, represents the front of the head, showing only the sides of the mandibles; $7 b$, the front of the body, seen sideways; $7 c$, the antennæ; $7 d$, the labrum; $7 e$, the maudible; $7 f$, the maxillæ; $7 g$, the mentum, \&c. ; $7 h$, the fore leg.

FIGURE 8.-HELOTA MELLII. WESTW.

Helota, supra renea, lateribus eupreis, punctata et rugosa, tubcreulisque clevatis elongatis mitidis, strias longitudinales in elytris formantibus, his etiam maculis 4 elevatis fulvis distiuetis; antenuis pieeo-flavis ; femoribus fulvis, apice viridibus; tibis alternatim fulvis et piceis; tarsis piceis, dimidio basali articuli ultimi fulvo ; corpore subtus pallide fulvo; capite (nisi in medio collaris) et lateribus thoracis viridilus ct punctatis.

Helota, with the upper surface of the body brassy, the sides copper-coloured ; punetured aud rugose ; and with elevated elongated slyining tubercles which form longitudinal strix on the elytra; the latter also marked with fom. raised fulvous round spots; thighs fulvous, with the tips green; tibiæ alternately fulvous and pitchy ; tarsi pitehy, basal laalf of the terminal joint of the tarsi fulvous; body beneath pale fulvous; the head, except in the niddle of the neck, and the sides of the thorax green and punctured.

Length of the insect, $4 \frac{1}{2}$ lines. Inlabits Simlah, in Thibet. In the Collection of A. Melly, Esq.

Observations.-The other species of the highly interesting and beantiful genus Helota, areSp. 2. H. Vigorsii, from Java, described and figured by Mr. MacLeay, in the Anmulosa Javanica.

Sp. 3. Helota Servillei, described and figured by Mr. Hope, in the Coleopterists' Manual, Part 3, p. 187, pl. 3, fig. 4, and details; from Poonah, in the East Indies.

Sp. 4. Helota Guerinii, described by Mr. Hope, in the same work, p. 188, but unfigured; from the East Indies, near Travancore, \&c., also communicated to me by Colonel Hearsey.

\section{FIGURE 9.-APATETICA LEBIOIDES. WESTW.}

Char Gen.-Geuus novum inter Coleoptera necrophaga, Pterolomæ maxime* affine; caput latum antice angustius ; labrum transversum angubs anticis rotundatis, medio emarginatum, margine antico membranaceo, ciliato ; nundibule corneæ, subfaleatæ, acutæ intus ciliatæ, haud dentatæ ; maxillæ lobo externo lato lrevi dense barbato, interno brevi, cilinto, inermi ; palpi maxillares breves filiformes; articulis 2 , 3, et 4 ferè requalibus ; mentum subquadratum; labium breve latum, emarginatum, dense ciliatum; palpi breves simplices ; autennæe elongatæe subfiliformes, articulis apicahbus parum crassioribus ; prothorax latus transversus lateribus rotundatis elevatis; margine postico supra basin seutelli parum transverse producto ; elytra subquadrata, subeonvexa ; pedes elongati, graciles ; tarsi setosi, 5-articulati, articulo 4 to subbilobo; antici breviores et latiores.

Genertc Character. - $\Lambda$ new genus among the Necrophagous Coleoptera, most nearly allied to Pteroloma. Head wide, narrowed in front ; labrum trausverse, with the anterior lateral angles rouuded; the middle emarginate ; the fore margin membranaceous and eiliated; mandibles corneous, somewhat siekle-shaped, acute at the tip, ciliated on the inner margin, not tootlied; maxillee, with the outer lobe broad, short, and densely bearded, imner love short, eilinted, unarmed ; maxillary palpi short, filform, with the 2,3 , and 4 joints, of nearly equal size ; mentuin subquadrate; labium short, broad, emarginate, and densely ciliated; palpi short, simple; antenna elongate, somewhat fliform, with the apical joints slightly thickened; prothorax broad, transverse, with the sides rounded and elevated, and the posterior margiu slightly transversely produced over the base of the seutellum; elytra subquadrate, subconvex, rounded at the outer posterior angles; legs long aud slender ; tarsi setose, 5-jointed, the 4 th joint subbilobed; the anterior tarsi sliorter and broader than the others.

Apatetica, nigra, nitida, lateribus prothoracis fulvis, elytris aneis ; eapite et pronoto punetatis, illo inter autennas bi-impresso; labro fulvo, mandibulis fulvo-piceis ; antennis fulvis ; elytris punctato-striatis ; femoribus æneis basi piceis ; tibiis tarsique fulvis; corpore subtus nigro nitido, marginibus inflexis elytrorum æeneis nitidis.

Apatetica, black and shining, the sides of the prothorax fulvous, and the clytra brassy green, head and pronotum punctured, the former with two impressions between the antenne ; lalirum and antennæ fulvous, mandibles pitcbyfulvous ; elytra punetate-striated ; thighs brassy-pitchy at the base ; tibiæ and tarsi fulvous ; body beneath, black and shining, with the inflexed margins of the elytra shining brsssy green.

Length of the insect, 4 lines. Inhabits the Himalayan region. In Mus. Westwood.

I am indebted to H. G. Harrington, Esq., for my unique specimen of this iuteresting insect. Figure $9 a$, represents the labrum; $9 b$, the mandible; $9 c$, the maxillæ; $9 d$, the labium, \&c.; $9 e$, the antennx; $9 f$, the fore tarsus ; $9 g$, one of the hind tarsi.

* Dr. Erichson has had the rare tact to discover and demonstrnte, in an article published in Wiegmann's Areluves, that the singular genus Pteroloma (Holocnemis, Schilling), placed by all preceding authors amongst the Carabida next to Neloria, belongs to the family Silphidæ, near to Catops and Agyrtes. The insect above described fully confirms this relation of Pteroloma. Elapbropus Caraboides of Motehoulsky, Bull, Mose. 1839, t. 5. fig. E. seems also to possess an affinity with these inseets. 



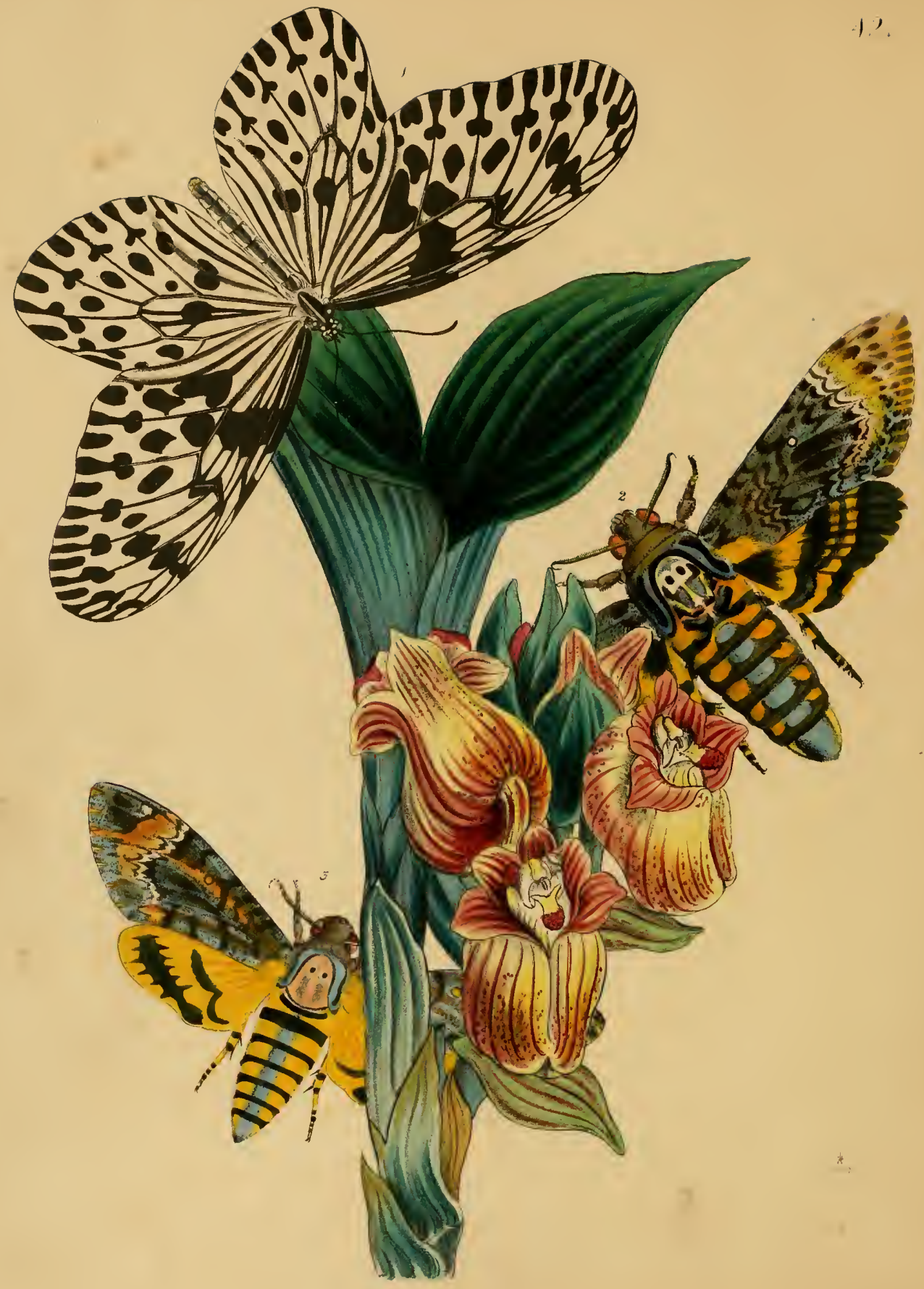






\title{
PLATE XLII.
}

(ORDER-LEPIDOPTERA.

\author{
Section-Dicrsa.
}

FIGURE 1.
FaMiLX-HeLCoNin.s.)

\section{IIESTIA IASONTA. WESTW.}

\begin{abstract}
Hestia alis sub-elongatis albis, nigro maculatis et venosis ; anticis tertia parte basali costro nigra, macula magna obliqua nigrn per aream discoidalem extensa, serieque maeularum subovalium pono medium ale cum margine apicali haud parallela (antieis propiorilus arex discoidali); posticis macula ovali nigra in medio arese discoidalis ; omnibuscue ad apicen maculis ovalibus inter veans aliisque majoribus clavatis alternatis.

Ilestia, with the wings ratler elongate, white, spotted and reincd with black; the anterior with the costa for one third of its extent from the base black, with a large black oblique spotextending across the discoidal cell, and a row of somewhat oval spots, variable in size, beyond the middle of the wing, not parallel with the apical margin (the spots towards the costa being nearer to the extrenity of the discoidal cell); the hind wings with an oval black spot in the midille of the discoidal cell; all the wings having a row of elongate oval spots along the apical nargin between the veins, which latter are marked at the extremity with an alternating scries of larger spots, which are chavate next the niddle of the wing.

Expansion of the fore wings, $5_{4}^{3}$ inclies.

Inlhabits the lsland of Ceylou. In the Collection of R. Templeton, Esq., R.A. (also in the British Museum).
\end{abstract}

Observations. - The two species of this genus, figured in Plate 37, will be at once perceived to differ from the one here represented in the position of the row of spots beyond the middle of the fore wings; in the former species, these spots form a nearly straight row, but in the present species, as well as iu H. Lrncen, they form an angulated line, those nearest the fore margin of the wing being nearcr to the body of the insect. How far this may be a good specific cliaracter, must be left for time (or, more properly speaking, the possession of an cxtensive series of specimens of these insects from different localities) to determine. It is doubtless, in some degree, dependent on the form of the apical angle of the wing, and this form of the wing, as a specific character, cannot at present, I belicve, be fully relied upon. That the form of the wing raries in some butterflies according to the localities of the indiriduals, is unquestionable; and if this should be ascertained to be the case here, I think it may possibly be followed by the discorery that all the supposed species of Hestia are only so many local or geograplical sub-species of one real species.

\section{FIGURE 2.}

\section{(Sectiox-Creptscularia. Famlix-Sphingide.) \\ SPHINX (ACHERONTIA) LETHE, WESTw.}

Sphinx alis anticisfuscis plumbeo irroratis, nigroque variegatis et undatis, basi apiceque luteo ferrugineoque magis variis, stigmate parvo albo, undulis albis seu albidis pone medium ad costrm magis conspicuis; alis posticis fulvis, brsi, fascia lata media (lnteo submaculata) fasciaqne lata marginali nigro-fuscis, margine ipso luteo submaculato ; corpore fusco thorace supra plumbeo utrinque strigis duabus nigricantibus, dorso facie valde variegata picto, fronte et naso albis, oculis nigris, auribus nigricantibus, genis griseis, ore lato undato ferrugineo barbaque nigricanti griseo parum irrorato; abdomine supra fusco, segmeutis in medio plumbeo maculatis, lateribusque luteo maculatis; pedibus latis, fulro annulatis.

Sphinx with the fore wings brown, irrorated with leaden-coloured scales and variegated with black markings, and undulated streaks; the base and especially the extremity of the wing"more varied with luteous and ferruginous, stigma small and white, a double series of white or whitish undulations beyond the middle of the wing, more conspicuous 
next the costa, hind wings fulvous; with the base, a central broad fascia (occasionally slightly spotted with luteous), and a broad apical wargin blackish-brown, the margin itself with a row of small luteous spots ; body brown varied with luteous, thorax above leaden-coloured, with two rich brown streaks on each side; the face upon the back much more varied in its colours than in the other species of this sub-genus, the forehead and nose very slender, white or whitish ; eyes black, ears rich brown, cheeks leaden, mouth very wide and wared ferruginous, moustachios and beard blackish-brown, slightly grey; upper side of the abdomen brown, each segment with a large central leadencoloured spot and with a lateral luteous spot; legs broad, annulated with fulrous.

Expansion of the fore wings of the female, 5 inches.

Inhabits various parts of the East Indies, Ceylon, \&.c. Communicated by Col. Hearsey and R. Templeton, Esq.

Syn. Acherontia Satanas? Bdv. Hist. Nat. Lep. Pl. 16, fig. 1. (fig. parva, sine descriptione).

Observation.-This species seems closely allied to the East Indian Sphinx Lachesis Fabr., especially in its dark lind wings; but the character "abdomine nigro flavo fasciato," will not agree with the insect here figured. I possess a manuscript reference of this Fabrician insect to Sphinx (" morti signalis, Cr, xx._237,") by the late Professor Weber of Keil.

\title{
FIGURE 3.
}

\section{SPHINX (ACHERONTIA) STYX. WESTW.}

\begin{abstract}
Sphinx alis anticis fuscis, plumbeo irroratis nigroque variegatis et undatis, apiceque luteo et ferrugineo magis rarïs, stigmate parvo luteo, undulis albidis pone medium ad costam magis conspicuis ; alis posticis fulvis, fasciis duabus nigricantibus : l ma, angusta mediana; 2nda, utrinque dentata submarginali ; corpore fusco, thorace supra lateribus plumbeis utrinque strigis duabus nigris ; fignra dorsali faciei coloris fusci ferê uniformis, oculis parvis migris, postice lunula nigra (striam curvatam plumbeam includente) cincta; abdomine fulvo ; segmento singulo macula parva quadrata plumbea dorsali incisurisque fuscis ; pedibus angustis luteo annulatis.

Sphinx with the fore wings brown, irrorated with leaden-coloured scales and variegated and waved with black, the extremity of the wing being more varied with luteous and ferruginous; stigma small and luteous and with a double row of whitisl undulated streaks beyond the middle of the wing, most conspicuous next the costa; hind wings fulvous with two blackish fascire, the first narrow and central, the second toothed on each side and sulb-marginal ; body brown, upper surface of the thorax leaden-coloured at the sides, with two black streaks on eacb side, the dorsal face-like mark nearly of an uniform dull reddish-brown colour, with two small black eyes, posteriorly margined by a black lunule including a slender leaden-coloured curved line; abdomen fulvous, each segment with a small square dorsal leaden spot and with the articulations brown; legs narrow, annulated with huteous.

Expansion of the fore wings, $4 \frac{1}{6}$ inches.

Inlsabits the East Indies. Communicated by Col. Hearsey.
\end{abstract}

Observatons. - This species is most ncarly allied to Sphinx Atropos, but differs from it in its smaller size, in the uniform colonr of the face-like marking on the back of the thorax, and in the slenderness of the limbs.

The plant represented in the Plate is the Javanese Orchidaceous Acanthophippium Javanicum. 





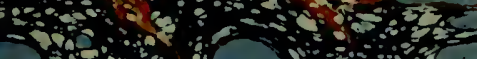

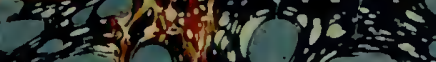

in' $-<$

\section{(2)}

soi t w

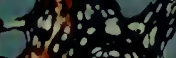

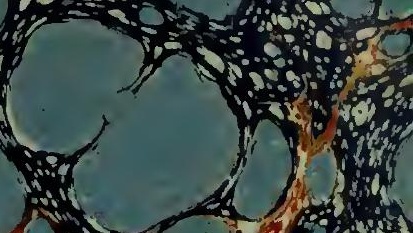

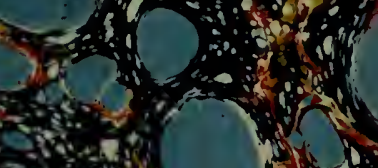

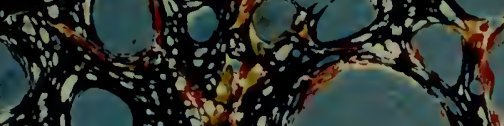

तुक्षे

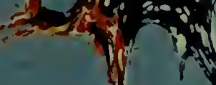

(n)

53 iventy

1)

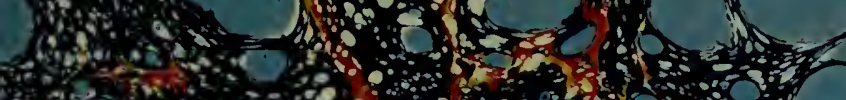

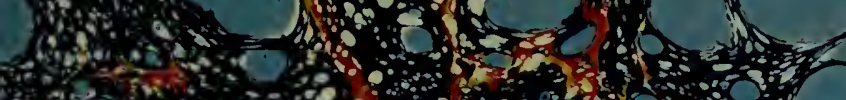

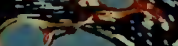

$\operatorname{lin}^{-1}$

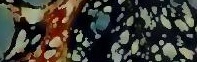

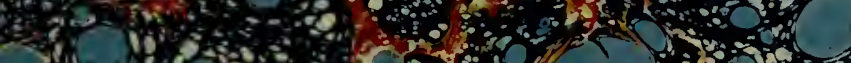

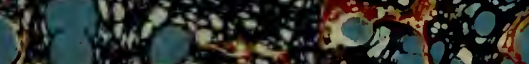

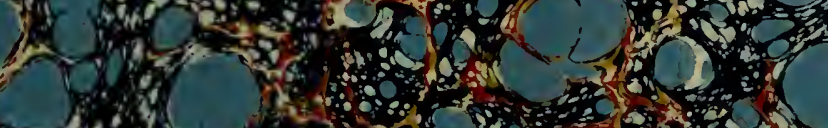

(3)

1.

a

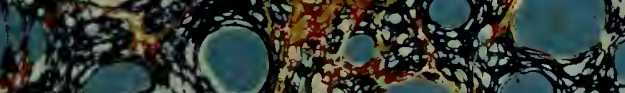

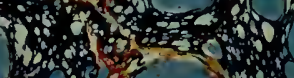

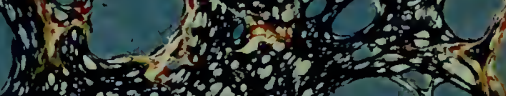

hish 20.000 $p$ sentis

-2. cos

ind

i. $r i f$

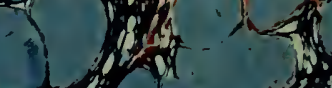

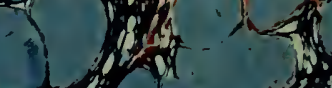

क.

$\therefore$

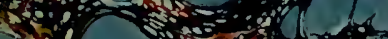

$=0$

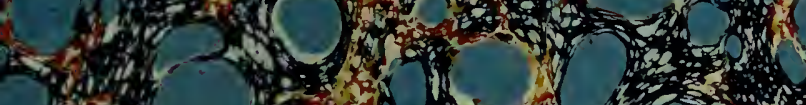

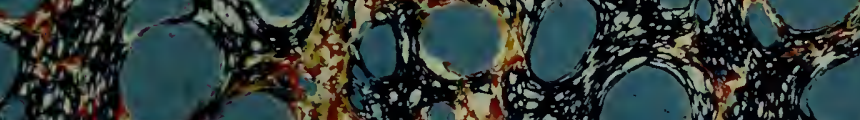

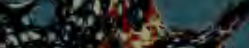

topis

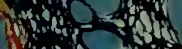

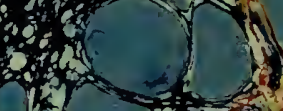

$x_{1}$

ig

$16 x^{2}+$ a

$2=-100$

iois

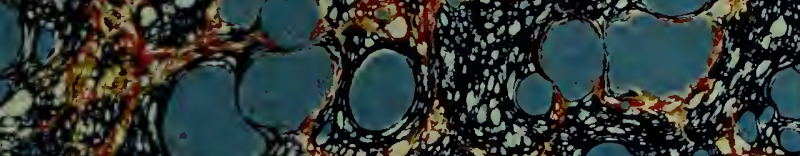

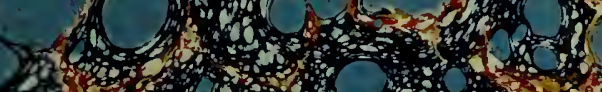

71 is 305

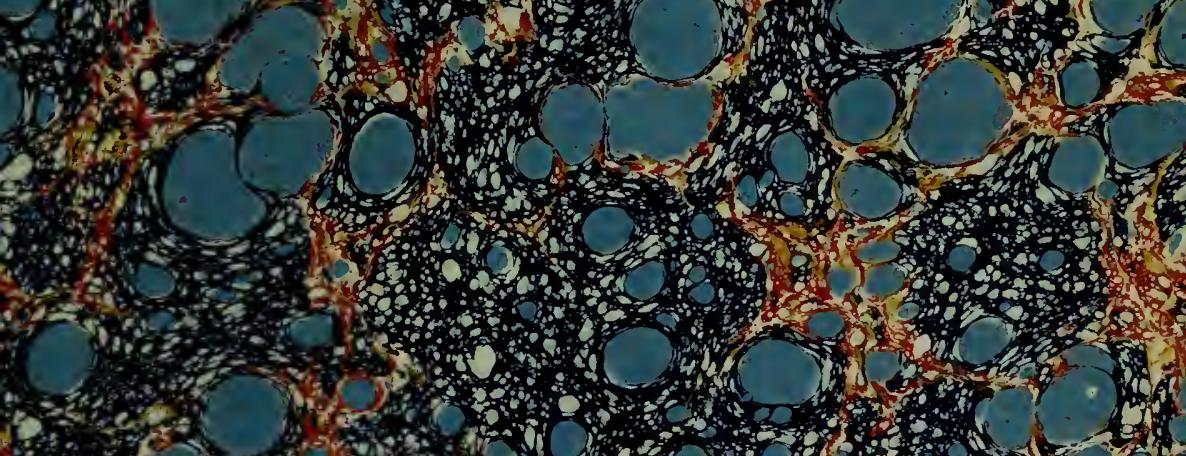

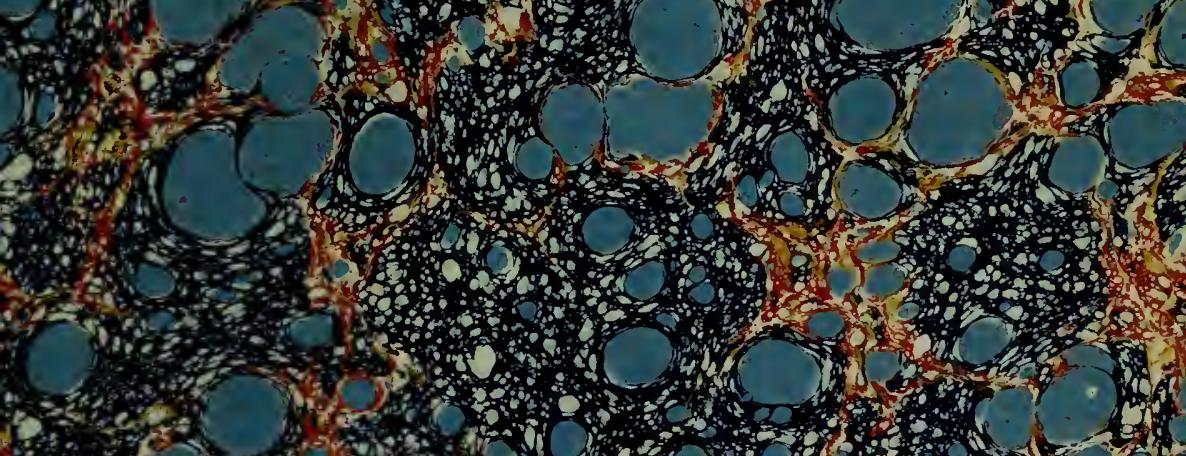

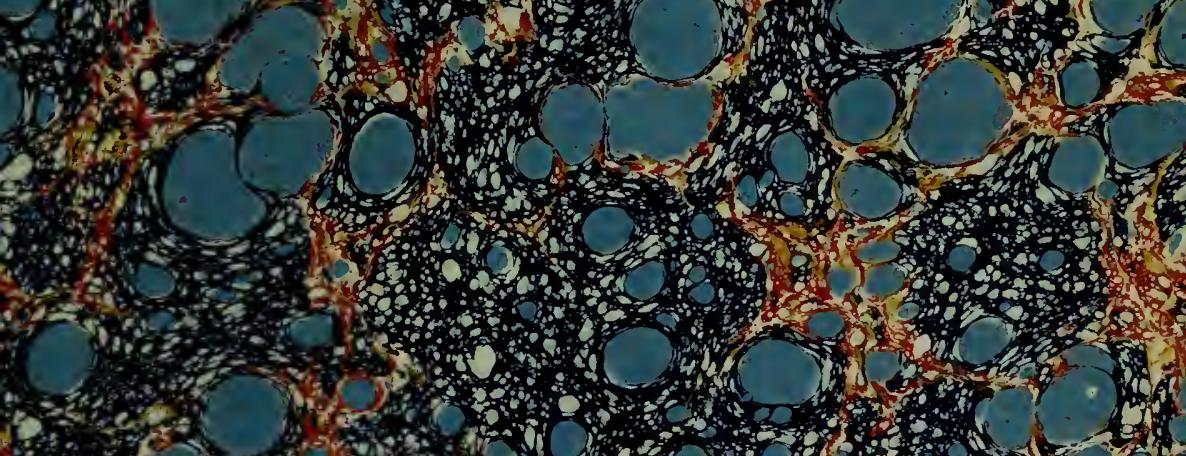

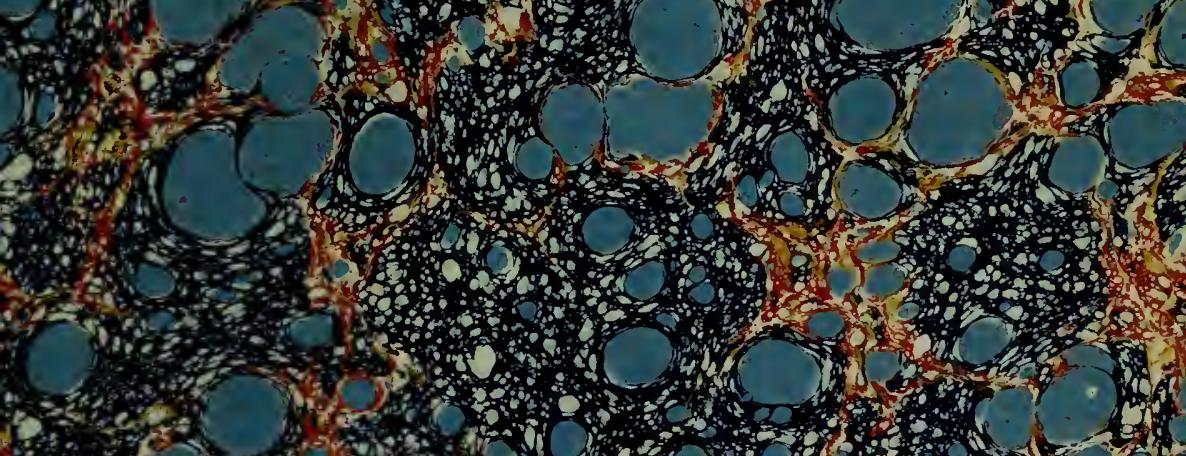

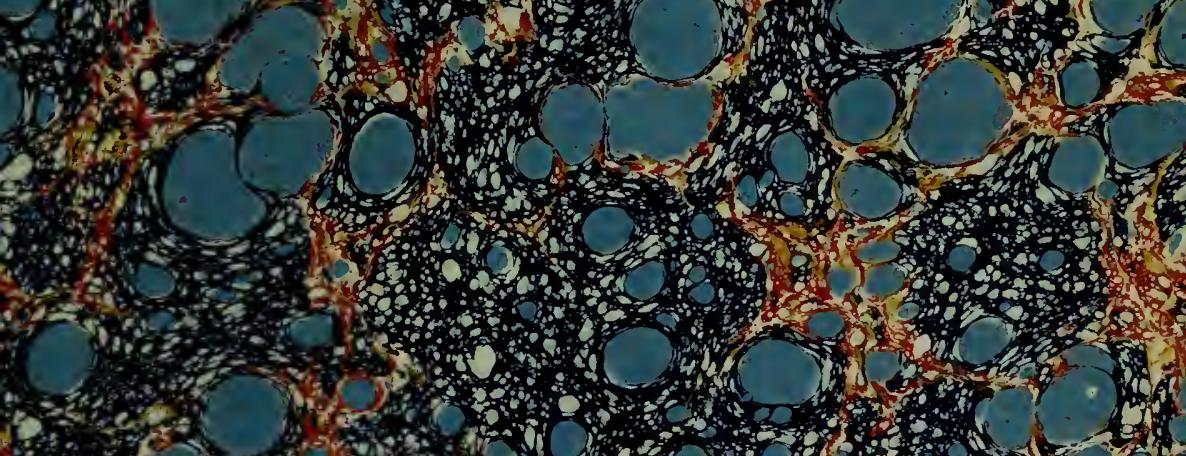

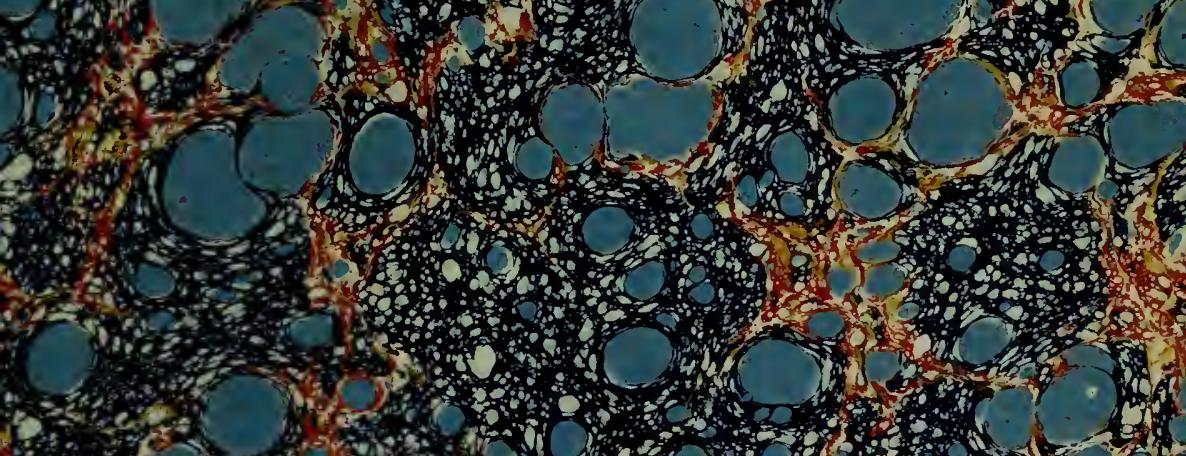

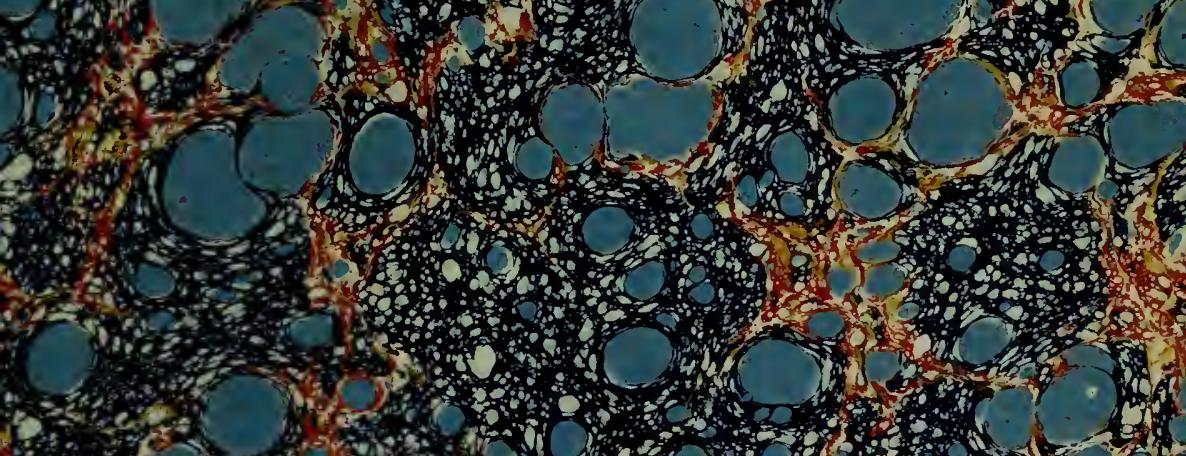

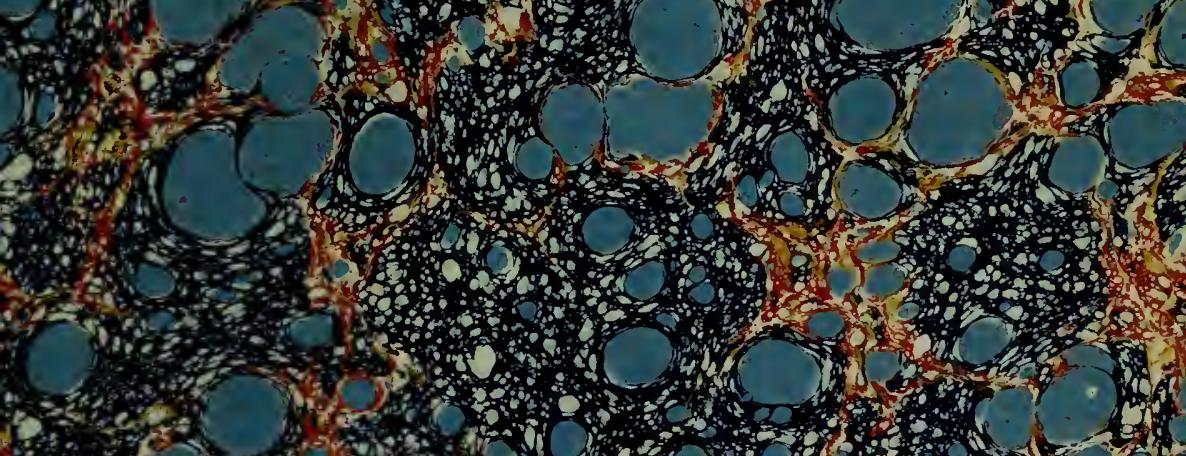

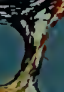

$1, x_{1}$

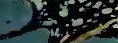

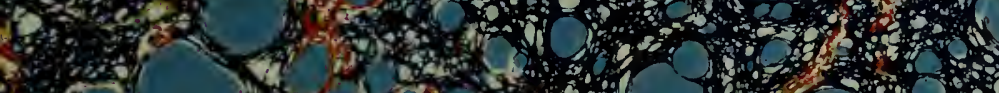

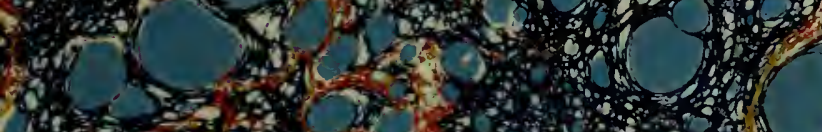

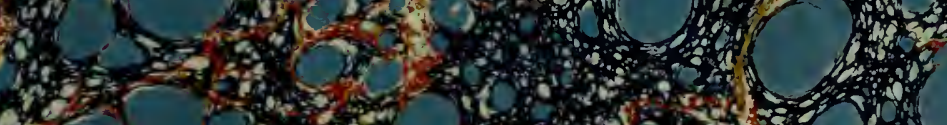




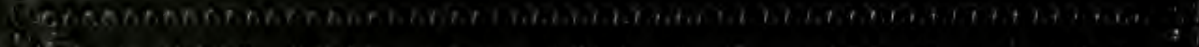

Q.

(1)

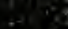

18 